UNIVERSIDADE DE SÃO PAULO

INSTITUTO DE GEOCIENCIAS

\title{
ASPECTOS GENÉTICOS E CARACTERÍSTICAS MINERALÓGICAS DO CRISOBERILO DAS LAVRAS DE ESMERALDAS DE FERROS E HEMATITA - MG
}

Sandra Akemi Iwata

Orientador: Prof. Dr. José Barbosa de Madureira Filho

\section{TESE DE DOUTORAMENTO}

Programa de Pós-Graduação em Mineralogia e Petrologia

\author{
SÃO PAULO \\ 2000
}




\title{
ASPECTOS GENÉTICOS E CARACTERÍSTICAS MINERALÓGICAS DO CRISOBERILO DAS LAVRAS DE ESMERALDAS DE FERROS E HEMATITA - MG
}

\author{
SANDRA AKEMI IWATA
}

Orientador: Prof. Dr. José Barbosa de Madureira Filho

TESE DE DOUTORAMENTO

COMISSÃO JULGADORA

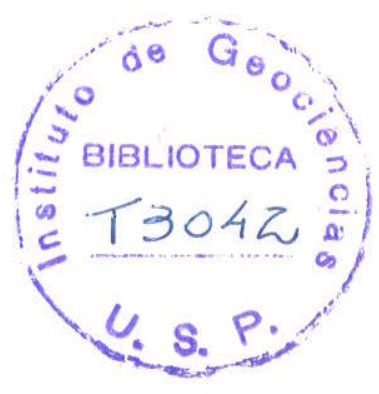

Nome

Assinatura

Presidente: Prof. Dr. José Barbosa de Madureira Filho

Examinadores: Prof. Dr. Johann Hans Daniel Schorscher

Prof. Dr. José Carlos Gaspar

Prof. Dr. Pedro Luiz Juchem

Prof $^{\text {a. }} \mathrm{Dr}^{\text {a. }}$ Vitória Régia Péres O. Marciano

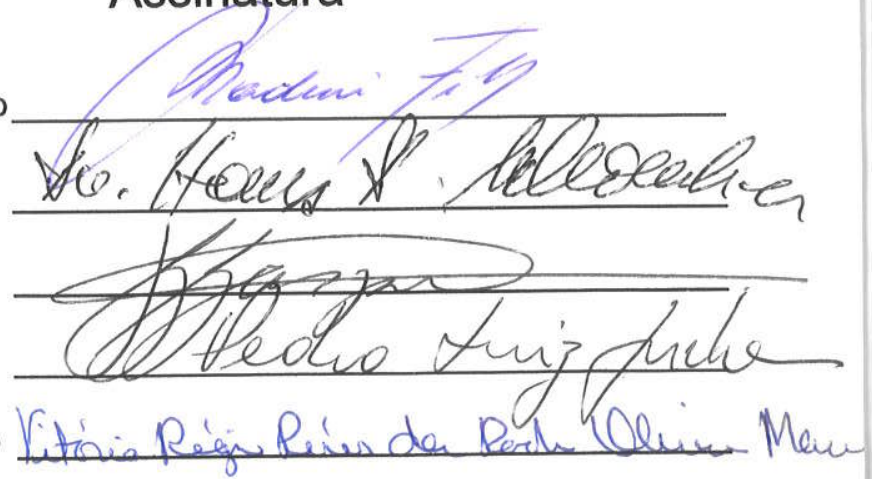

$$
\begin{aligned}
& \text { SÃO PAULO } \\
& 2000
\end{aligned}
$$




\section{ASPECTOS GENÉTICOS E CARACTERÍSTICAS MINERALÓGICAS DO CRISOBERILO DAS LAVRAS DE ESMERALDAS DE FERROS E HEMATITA - MG}

Sandra Akemi Iwata

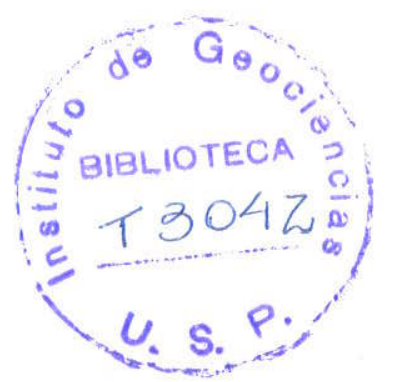

Orientador: Prof. Dr. José Barbosa de Madureira Filho

\section{TESE DE DOUTORAMENTO}

Programa de Pós-Graduação em Mineralogia e Petrologia

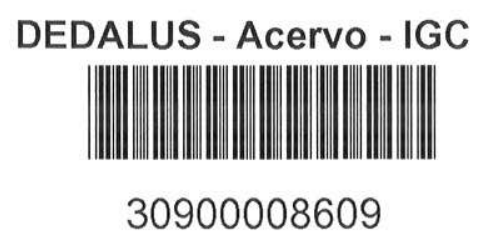

$$
\begin{aligned}
& \text { SÃO PAULO } \\
& 2000
\end{aligned}
$$




\section{AGRADECIMENTOS}

Os mais sinceros agradecimentos são dirigidos àquelas pessoas ou instituições que de alguma forma contribuíram para a realização deste trabalho:

- ao Prof. Dr. José Barbosa de Madureira Filho, pela orientação e constante apoio no desenvolvimento desta tese;

- aos proprietários da Mineração Itaitinga, Xistinho e Fernando;

- ao pessoal técnico dos laboratórios do IG-USP, em especial Marcos, Flávio e Aninha;

- aos amigos e colegas da pós-graduação, pela convivência agrad ável;

- à FAPESP, pelo suporte financeiro através dos processos 95/9388-1 e 95/4637-3;

- ao DAAD, pela concessão de bolsa de doutorado sanduíche;

- e finalmente, ao Sérgio Luís, cujo apoio foi crucial em vários momentos deste trabalho. 


\section{RESUMO}

Ocorrências de esmeralda, água-marinha e crisoberilo delineiam, na região a NE de Belo Horizonte, Estado de Minas Gerais, uma faixa de mineralização berilifera entre as cidades de Nova Era e Ferros.

No presente trabalho foram investigadas as propriedades mineralógicas do crisoberilo da Lavra de Esmeraldas de Ferros, seu modo de ocorrência e gênese. A alexandrita proveniente do depósito aluvionar de Hematita também foi caracterizada, para fins de comparação.

$\mathrm{O}$ arcabouço geológico da área comprende rochas metaultramáficas, anfibolitos e metassedimentos dos supergrupos Rio das Velhas e Minas, em contato com uma unidade granito-gnáissica equivalente ao Granito Borrachudos e denominada informalmente de Ortognaisse Açucena.

A ocorrência primária de Esmeraldas de Ferros apresenta uma associação raramente descrita, onde cristais da variedade alexandrita do crisoberilo foram formados pela percolação de fluidos ricos em Be através de uma rocha metassedimentar, um biotita xisto grafitoso pertencente à unidade denominada Gnaisse Monlevade.

As condições sob as quais desenvolveu-se esse processo genético foram estimadas com base em informações sobre a geologia regional, dados microtermométricos e estabilidade dos minerais berilíferos, obtendo-se temperatura de $700^{\circ} \mathrm{C}$ e pressão em torno de $5,5 \mathrm{kbar}$. Esses valores encontram-se em acordo com evidências de campo e trabalhos experimentais desenvolvidos por outros autores, que sugerem a estabilidade da associação crisoberilo + quartzo em condições próximas à anatexia.

Nesse regime metamórfico elevado, a presença do $\mathrm{CO}_{2}$, aprisionado como inclusões fluidas de alta densidade em veios de quartzo, teria um duplo papel na mineralização: servir como meio de transporte para o $\mathrm{Be}$, na forma de complexos, e reduzir a atividade de sílica, favorecendo a precipitação de crisoberilo em lugar de berilo.

Com referência ao material estudado, as maiores diferenças entre a alexandrita proveniente das duas ocorrências residem na morfologia e propriedades gemológicas: enquanto a alexandrita de Esmeraldas de Ferros é 
encontrada na forma de cristais ou fragmentos de pequenas dimensões (inferiores a $0,5 \mathrm{~cm}$ ), pouco transparentes, ricos em inclusões sólidas e com efeito olho-de-gato, o material obtido em Hematita ocorre na forma de fragmentos de maior dimensão, apresenta transparência elevada e raras inclusões sólidas, o que the confere alto valor gemológico.

A presença de inclusões de grafita, até o momento não descritas em alexandritas de outras localidades, é uma feição típica do material de Esmeraldas de Ferros.

No tocante à composição química, a diferença principal reside nos teores em $\mathrm{Fe}_{2} \mathrm{O}_{3}$ menos elevados em Esmeraldas de Ferros em comparação com a alexandrita de Hematita, conferindo às primeiras um tom mais azulado.

Na separação de material sintético, o espectro de absorção no infravermelho e o conjunto de inclusões sólidas seriam característicos das alexandritas de Esmeraldas de Ferros e Hematita. 


\section{ABSTRACT}

Northeast of Belo Horizonte, Minas Gerais State, a series of emerald, aquamarine and chrysoberyl occurrences delineate a region of beryllium mineralizations.

In the present work, the chrysoberyl from the Esmeraldas de Ferros Mine was investigated, regarding its mineralogical properties, mode of occurrence and formation. For means of comparison, alexandrite from the Hematita Mine was also subject of analyses.

The geological framework comprises metaultramafic rocks, anfibolites and metasediments from Rio das Velhas and Minas Supergroups, adjacent to a granitic-gneissic unit equivalent to the Borrachudos Granite and informally named Açucena Orthogneiss.

At the primary occurrence of Esmeraldas de Ferros, a rarely described association is encountered, where the alexandrite variety of the chrysoberyl crystallized during the infiltration of Be-rich fluids through a metasedimentary rock, a graphite bearing biotite schist belonging to the Monlevade Gneiss.

Based on information about the geological setting, microthermometry data and beryllium mineral stabilities, the conditions under which the aforesaid genetic process took place could be estimated. The obtained values, with a temperature at $700^{\circ} \mathrm{C}$ and a pressure around $5,5 \mathrm{kbar}$, are in accordance with field evidence and experimental work undertaken by other researchers which suggest conditions aproaching anatexy for the stability of the chrysoberyl and quartz association.

In this high metamorphic environment $\mathrm{CO}_{2}$, trapped as high density fluid inclusions in quartz veins, played an important role during the mineralization, acting as a transport media for Be and favouring chrysoberyl precipitation in place of beryl, by reducing silica activity.

Comparing the alexandrites from Esmeraldas de Ferros and Hematita, the most striking differences concern morphology and gemmological properties: whereas the alexandrite from Esmeraldas de Ferros is found as small crystalls and fragments (under $0,5 \mathrm{~cm}$ ), with low transparency, rich in solid 
inclusions and showing cat's eye effect, the material recovered at Hematita contains larger, highly transparent fragments with rare solid inclusions, attributes which confer high gemmological value.

The presence of graphite inclusions, not described in alexandrites from other localities as yet, is considered typical for the material from Esmeraldas de Ferros.

Regarding chemical composition, the main difference corresponds to the lower $\mathrm{Fe}_{2} \mathrm{O}_{3}$ contents in the Esmeraldas de Ferros material as compared to that from Hematita, and which is responsible for the bluish colours in the former.

The infrared absorption spectra and the solid inclusions can be considered distinctive for the alexandrites from Esmeraldas de Ferros in comparison to synthetic material. 
SUMÁRIO

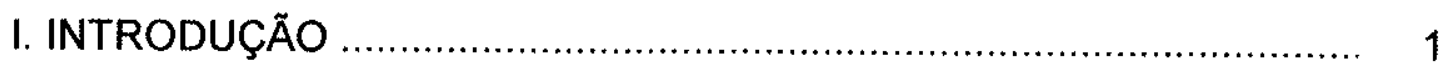

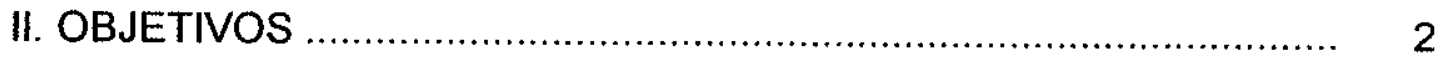

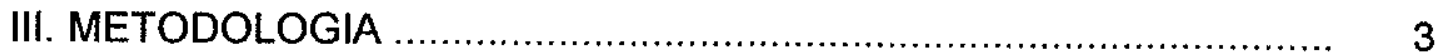

III.A. Trabalhos de Campo e Amostragem ................................... 3

III.B. Microscopia Óptica ........................................................... 3

III.C. Fluorescência de Raios X e Absorção Atômica ..................... 3

III.D. Microtermometria de Inclusões Fluidas ............................... 3

III.E. Isótopos Estáveis de Carbono ................................................ 4

III.F. Minerais Pesados e Tipologia do Zircão ............................... 4

III.G. Caracterização do Crisoberilo ................................................. 5

IV. O MINERAL CRISOBERILO …................................................

IV.A. Propriedades Físicas …...................................................... 9

IV.B Variedades Gemológicas ..................................................... 13

IV.C. Efeito Alexandrita ............................................................. 13

IV.D. Crisoberilo Sintético .......................................................... 15

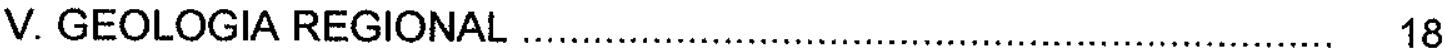

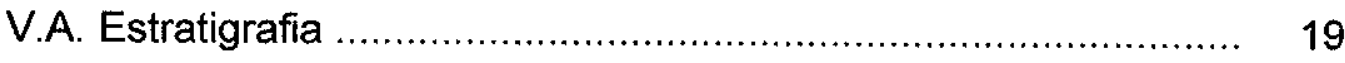

V.B. Evolução Geológica ......................................................... 23

V.C. Mineralizações Beriliferas .................................................... 29

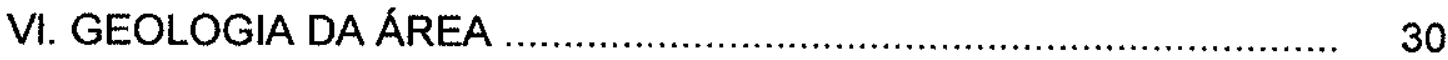

VI.A. Unidades Litológicas ..................................................... 31

VI.B. Caracterização Geoquímica das Unidades Litológicas ......... 39

VI.C. Química Mineral ........................................................ 48

VI.D. Metamorfismo e Deformação .............................................. 56

VI.E. O Ortognaisse Açucena e o Granito Borrachudos ............... 59

VI.F. Ocorrências de Crisoberilo e Esmeralda ............................ 60

VI.G. Minerais Pesados e Tipologia do Zircão ............................... 64

VII. MICROTERMOMETRIA DE INCLUSÕES FLUIDAS …................... 72

VIII. ISÓTOPOS ESTÁVEIS DE CARBONO …................................... 80

IX. CARACTERIZAÇÃO MINERALÓGICA DO CRISOBERILO ............ 83 
IX.A. Propriedades Físicas ..................................................... 83

IX.B. Feições Internas ......................................................... 86

IX.C. Composição Química, Efeito Alexandrita e

Catodoluminescëncia ....................................................... 88

IX.D. Espectros de Absorção no Infravermelho ............................ 96

IX.E. Parâmetros de Cela Unitária ............................................... 99

IX.F. Resumo das Propriedades .............................................. 100

X. GÊNESE DO CRISOBERILO ...................................................... 105

X.A. Ocorrências Primárias de Crisoberilo .................................. 105

X.B. Trabalhos Experimentais ................................................... 107

X.C. Gênese do Crisoberilo das Lavras de Esmeraldas de Ferros e Hematita ................................................................... 111

XI. CONSIDERAÇŐES FINAIS .................................................... 114

XII. REFERÊNCIAS BIBLIOGRÁFICAS ........................................ 115 


\section{ÍNDICE DAS FIGURAS}

Fig.l.1: Localização da área de estudo ................................................

Fig.IV.1: Morfologia do crisoberilo ..................................................... 10

Fig.IV.2: Estrutura do crisoberilo ........................................................ 11

Fig.IV.3: Espectros de absorção do rubi, esmeralda e crisoberilo .......... 14

Fig.V.1: Mapa geológico do Quadrilátero Ferrífero e adjacências (Schorscher 1992) ......................................................... 20

Fig.V.2: Mapa geológico do bordo SE do Cráton do São Francisco

(Grossi Sad et al. 1990) ...................................................... 27

Fig.V.3: Ocorrências de Granito Borrachudos (Fernandes et al. 1994) ... 28

Fig.VI.1: Classificação das rochas gnáissicas ...................................... 40

Fig.VI.2: Diagramas $\mathrm{SiO}_{2} x$ demais óxidos ......................................... 43

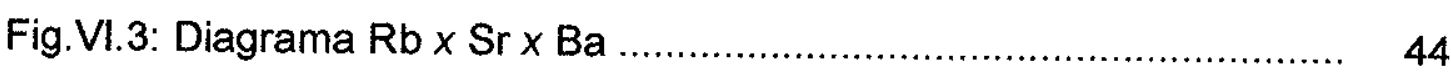

Fig.VI.4: Teores de Be nas rochas gnáissicas ..................................... 44

Fig.VI.5: Classificação das rochas metaultramáficas .............................. 45

Fig.VI.6: Diagramas $\mathrm{K}_{2} \mathrm{O}$ x elementos traço ....................................... $\quad 46$

Fig.VI.7: Classificação dos anfibólios ............................................... $\quad 50$

Fig.VI.8: Classificação das micas ....................................................... $\quad 52$

Fig.VI.9: Classificação das cromitas ..................................................... 54

Fig.VI.10: Variação composicional das cromitas ................................... 54

Fig.VI.11: Campos composicionais das cromitas ................................ $\quad 56$

Fig.VI.12: Spidergram das rochas ortognáissicas .............................. 59

Fig.VI.13: Diagrama de tipologia do zircão ......................................... 67

Fig.VII.1: Isócoras ....................................................................... 74

Fig.VII.2: Temperaturas de homogeniezação total ............................... 74

Fig.IX.1: Espectros de catodoluminescência de alexandrita ................... 95

Fig.IX.2: Espectro de catodoluminescência de alexandrita sintética ....... 95

Fig.IX.3: Espectros de absorção no infravermelho ............................... $\quad 97$

Fig.X.1: Minerais do sistema BASH em diagrama PXT (Burt 1978) ........ 108

Fig.X.2: Relações de fase no sistema BASH (Franz \& Morteani 1981) ... 108

Fig.X.3: Relações de fase no sistema BASH (Barton 1986) ................... 109 
Fig.X.4: Estabilidade no sistema BASH $x$ atividade de sílica ................. 110

Fig.X.5: Estabilidade da associação crisoberilo + quartzo e isócora ....... 113 


\section{ÍNDICE DAS TABELAS}

Tab.IV.1: Constantes cristalográficas e propriedades do crisoberilo

Tab.IV.2: Teores máximos em elementos traço em crisoberilos

(Henn 1985)

12

Tab.V.1: Coluna estratigráfica do Supergrupo Rio das Velhas .............. 22

Tab.V.2: Coluna Estratigráfica do Supergrupo Minas ............................. 24

Tab.VI.1: Composições químicas de gnaisses ...................................... 41

Tab.VI.2: Composições químicas de metaultramáficas ......................... 47

Tab.VI.3: Composições químicas de anfibólios .................................... 49

Tab.Vl.4: Composições químicas de micas ......................................... 51

Tab.V1.5: Composições químicas de cromitas ........................................ 53

Tab.VII.1: Resultados microtermométricos .......................................... 73

Tab.IX.1: Composições químicas de crisoberilos .................................. 89

Tab.IX.2: Composições químicas de crisoberilos ................................... 91

Tab.IX.3: Linhas de absorção no infravermetho ................................... 98

Tab.IX.4: Parâmetros de cela unitária .................................................. 99 


\section{INDICE DAS PRANCHAS}

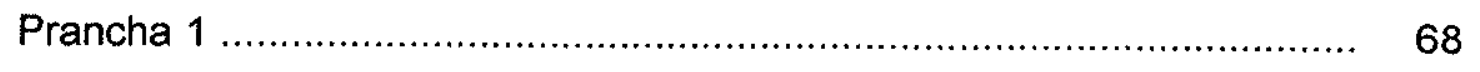

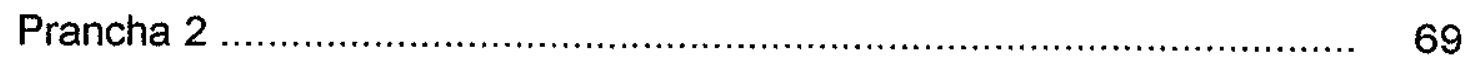

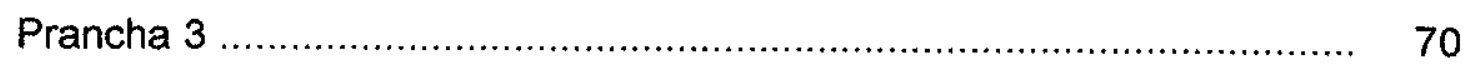

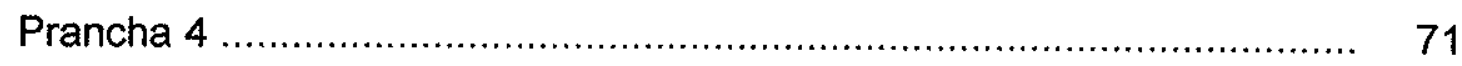

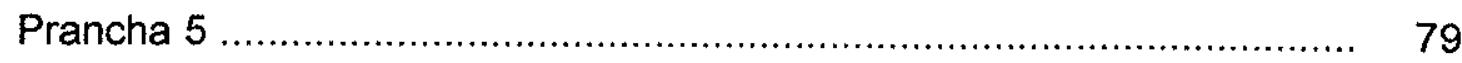

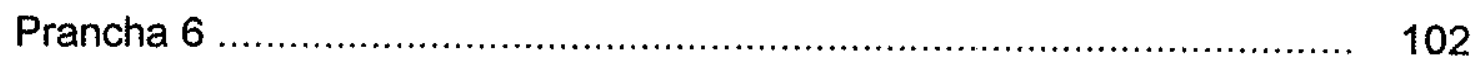

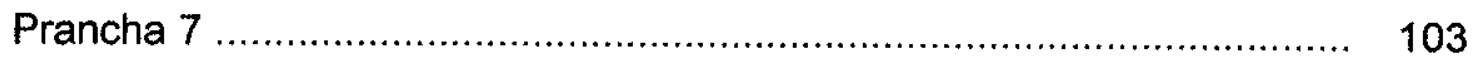

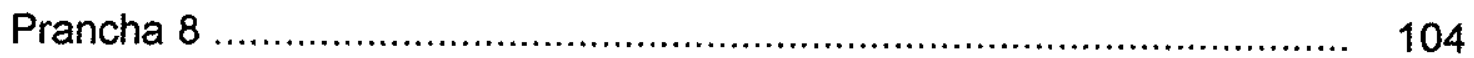




\section{INTRODUÇÃO}

$O$ principal interesse econômico do crisoberilo, $\mathrm{BeAl}_{2} \mathrm{O}_{4}$, está na sua utilização como material gemológico. É um mineral de ocorrência relativamente restrita, sendo poucas as localidades fornecedoras de crisoberilo no mundo. Atualmente destacam-se apenas Sri Lanka e Brasil, onde a produção provém de depósitos localizados nos estados de Minas Gerais, Bahia e Espírito Santo (Cassedanne \& Roditi 1993), tendo sido descritas recentemente ocorrências também em Goiás (Petersen Jr. 1998).

Neste trabalho são estudadas as lavras de Esmeraldas de Ferros e Hematita, localizadas no Estado de Minas Gerais, aproximadamente $200 \mathrm{~km}$ a NE de Belo Horizonte (Fig.I.1).

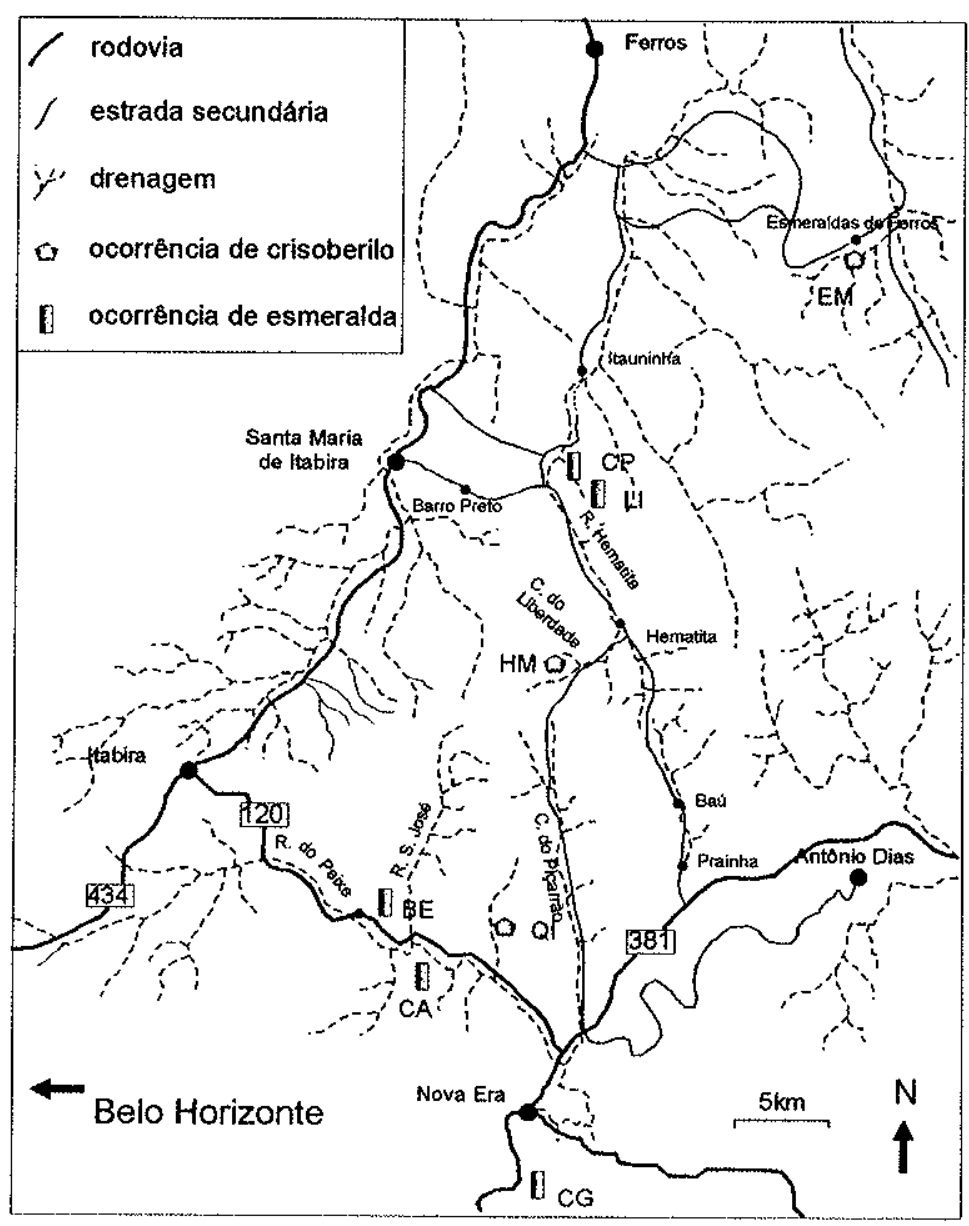

Fig.l.1: Localização das ocorrências de crisoberilo e esmeralda a NE da cidade de Belo Horizonte. Ocorrências de crisoberilo: EM - Esmeraldas de Ferros; HM - Hematita; QI - Quilombo. Ocorrências de esmeralda : BE - Belmont; CA - Capoeirana; CG - Cantagalo; CP - Córrego das Pedras; LI Limeira. BE e CA: estudadas por Souza (1988) e Machado (1994, 1998). 
O depósito aluvionar de Hematita, descoberto em 1986, foi explorado inicialmente por garimpeiros e produziu dezenas de quilos de crisoberilo, variedade alexandrita, de ótima qualidade (Proctor 1988). Atualmente, a área é explorada por duas empresas, a Alexandrita Mineração Comércio e Exportação Ltda., detentora da maior jazida de alexandrita do mundo (potencial medido de $53 \mathrm{~kg}$ - Folha de São Paulo 1996), e a Mineração Itaitinga, proprietária de uma área menor e que permitiu os trabalhos desta pesquisa.

Em Esmeraldas de Ferros, Karfunkel \& Wegner (1993) descreveram uma das poucas ocorrências de alexandrita na rocha primária, um xisto muito alterado com níveis quartzo-feldspáticos.

Além das ocorrências de crisoberilo, outras mineralizações beriliferas são exploradas na região, como esmeralda e água-marinha.

\section{OBJETIVOS}

Os objetivos do presente trabalho incluem o estudo das propriedades mineralógicas do crisoberilo da região de Esmeraldas de Ferros e Hematita, seu modo de ocorrência e gênese.

A plena caracterização de um material de uso gemológico é extremamente importante para facilitar a diferenciação entre o material natural e o sintético, um problema de grandes dimensões quando são considerados os altos valores de comercialização que podem ser alcançados por uma alexandrita natural de boa qualidade. Portanto, neste trabalho procurou-se a determinação de propriedades que possam ser consideradas típicas das gemas provenientes da região em questão.

No entanto, o principal objetivo deste projeto consiste na investigação do processo formador da mineralização no que diz respeito a intrusão de corpos pegmatíticos, circulação de fluidos metassomáticos, atuação de controles estruturais, idade da mineralização e relação com eventos tectono-metamórficos regionais. 


\section{METODOLOGIA}

III.A. Trabalhos de Campo e Amostragem

Nesta etapa procurou-se o reconhecimento das litologias presentes na área, feições estruturais e indícios sobre os processos de mineralização.

$O$ fato de algumas ocorrências de esmeralda estarem em produção e contarem com trabalhos subterrâneos facilitou a amostragem nessa área de intemperismo muito intenso.

\section{III.B. Microscopia Óptica}

Foram empregadas tanto luz transmitida quanto refletida para o reconhecimento em lâmina de feições de deformação, reações metamórficas/metassomáticas, identificação mineralógica e seleção de amostras para análises subseqüentes.

III.C. Fluorescência de Raios X e Absorção Atômica

Análises químicas em rocha total foram obtidas por fluorescência de raios $X$ em equipamento Siemens, modelo SR303, enquanto teores de Be foram dosados por absorção atômica, ambas na Universidade Técnica de Munique

III.D. Microtermometria de Inclusões Fluidas

Estudos de microtermometria de inclusões fluidas foram desenvolvidos em amostras de alexandrita, esmeralda e quartzo, buscando-se o reconhecimento dos fluidos responsáveis pela mineralização.

O equipamento utilizado, pertencente à Universidade Técnica de Munique, consistiu em microscópio Leitz acoplado a platina de resfriamento e aquecimento Linkam THM600, com sistema de resfriamento Linkam LNP a base de $\mathrm{N}_{2}$ líqüido que permite temperaturas mínimas em torno de $-194^{\circ} \mathrm{C}$. 
$\mathrm{Na}$ calibração do equipamento foi utilizado um conjunto de cinco padrões SYNFLINC, consistindo em inclusões fluidas sintéticas em discos de quartzo.

Descrições detalhadas do método e seus princípios podem ser encontrados em Roedder (1984), Shepherd et al. (1985), dentre outros.

III.E. Isótopos Estáveis de Carbono

O trabalho de Hoefs (1997) apresenta as bases da geoquímica de isótopos estáveis. Emery \& Robinson (1993) trazem também uma descrição muito detalhada dos princípios do método.

Neste trabalho foi determinado $\delta^{13} \mathrm{C}$ de inclusões fluidas presentes em veios de quartzo e de grafita, ambos associados à mineralização de alexandrita da Lavra de Esmeraldas de Ferros.

Para a extração do $\mathrm{CO}_{2}$ contido nas inclusões fluidas utilizou-se o método da armadilha fria (cold trap), descrito em Roedder et al. (1963). A transformação da grafita em $\mathrm{CO}_{2}$ deu-se na presença de $\mathrm{CuO}$, por aquecimento a $900^{\circ} \mathrm{C}$ em tubo de sílica durante uma hora. A leitura das razões isotópicas foi realizada em equipamento Finnigan MAT 251 dual inlet IR-MS, pertencente à Universidade Técnica de Munique.

\section{III.F. Minerais Pesados e Tipologia do Zircão}

O rejeito mineral do tanque de decantação da ocorrência aluvionar de Hematita foi tratado para o estudo dos minerais pesados. Após lavagem em bateia, os minerais opacos foram retirados no separador isodinâmico Frantz, enquanto os minerais transparentes foram selecionados para identificação em lupa binocular. A identificação dos minerais transparentes foi realizada por microscopia em luz transmitida de montagens de grãos, recorrendo-se à difratometria de raios $X$ nos casos onde ainda persistiam dúvidas. A identificação dos minerais opacos baseou-se na observação de seções polidas em luz refletida.

Da fração menos magnética foram ainda separados grãos de zircão para aplicação do método da tipologia do zircão, proposto por Pupin (1980), o qual baseiase na identificação das formas prismáticas e piramidais apresentadas pelo mineral 
para correlação com condições de temperatura e características químicas de seu ambiente de cristalização.

\section{III.G. Caracterização do Crisoberilo}

\section{III.G.1. Cor}

$\mathrm{Na}$ caracterização da cor do material, procurou-se adotar um procedimento adicional que permitisse eliminar, ao menos em parte, o caráter subjetivo da atribuição de cores por simples estimativa visual. Disso resultou a utilização do sistema de classificação de cores de Munsell (1976), o qual baseia-se na comparação visual entre as cores da amostra e de aproximadamente 1500 padrões, arranjados em 40 tabelas de matizes (HUE).

Os matizes são representados por letras: $R$ (red), $Y R$ (yellow-red), $Y$ (yellow), GY (green-yellow), G (green), BG (blue-green), B (blue), PB (purple-blue), P (purple), RP (red-purple). Em cada tabela de matiz os padrões encontram-se arranjados segundo linhas (Value) e colunas (Chroma):

- Value ( $V$ ) é definido como o brilho de uma cor (lightness ou darkness) em relação a uma escala neutra de cinza, que pode variar do preto absoluto $(0 / .$.$) ao branco$ absoluto (10/...). Na prática, tanto o branco como o preto absoluto não são possíveis, portanto $\mathrm{V}$ assume valores entre $2 / \ldots$ e $9 / \ldots$.

. Chroma (C) representa a saturação de uma cor, ou "o distanciamento de um dado matiz em relação a um cinza neutro de mesmo $V$ ". Pode variar entre .../0 (cinza neutro) e .../10, ../12, ../14 ou até valores maiores.

Cada padrão do sistema de Munsell recebe uma notação completa: $\mathrm{H}$ V/C, onde $\mathrm{H}=$ matiz (Hue), $\mathrm{V}=$ brilho (Value) e $\mathrm{C}=$ saturação (Chroma).

A classificação das amostras de crisoberilo (empregadas sem nenhuma preparação) de acordo com os padröes do Sistema de Munsell foi realizada sob as seguintes condições:

observação sob luz branca: padrão e amostra sobre fundo branco, lâmpada fluorescente no teto como única fonte de luz, ângulo de iluminação $90^{\circ}$; 
. observação sob luz incandescente: padrão e amostra sobre fundo branco, lâmpada fluorescente no teto e iluminação lateral $\left(45^{\circ}\right)$ com lanterna de bolso.

O sistema de Munsell também é utilizado pela GIA- GTL (Gemological Institute of America Gem Trade Laboratory) na classificação de diamantes coloridos (fancy colors), para os quais a raridade e grande variação de cores tornariam inviável a comparação com padrões compostos essencialmente de conjuntos de diamantes naturais (King et al. 1994).

Também Rao et al. (1996) fizeram uso do sistema de Munsell na descrição da cor de águas-marinhas do Rio Grande do Norte.

\section{III.G.2. Índice de refração}

Neste item foi utilizado o refratômetro gemológico, especialmente desenhado para permitir o exame de gemas lapidadas e que, juntamente com o microscópio, polariscópio, dicroscópio e o espectroscópio, constitui-se num dos equipamentos essenciais da Gemologia.

A construção do refratômetro gemológico baseia-se no fenômeno da reflexão interna total, que ocorre quando um raio luminoso, viajando de um meio opticamente mais denso para um de menor densidade, atinge a interface entre esses dois meios segundo um ângulo de incidência maior do que o ângulo crítico, sendo então refletido de volta para o meio mais denso.

No refratômetro, esse meio mais denso corresponde a um prisma truncado ou semi-esfera de um vidro especial $(n=1,81)$ sobre o qual é posicionado o material a ser investigado, o qual deve ter uma superfície polida. Os raios que atingem a interface vidro/pedra a um ângulo maior que o crítico são refletidos $e$ retornam ao interior do instrumento, onde vão iluminar parte de uma escala visivel na ocular do aparelho. Para assegurar a continuidade óptica entre gema e vidro um líqüido de contato, também com $n=1,81$, é empregado.

As medidas apresentadas neste trabalho foram obtidas em refratômetro marca Schindler, pertencente ao Laboratório de Gemologia do DMG-IG-USP. O tamanho mínimo da amostra corresponde a $2 \mathrm{~mm}$ e, embora elas não tenham sido preparadas na forma de seções orientadas, o fato de a luz no refratômetro ser 
polarizada segundo $\mathrm{N}-\mathrm{S}$ permite que várias direções de vibração sejam medidas apenas rotacionando-se a amostra.

\section{III.G.3. Densidade relativa}

Medidas da densidade relativa de amostras brutas de crisoberilo foram obtidas pelo método hidrostático, que utiliza-se do princípio de Arquimedes (ou do empuxo) (Anderson 1980):

$$
d=\left[\text { peso }_{a r} /\left(\text { peso }_{a r}-\text { peso }_{\text {água }}\right)\right] \times d_{\text {Ilquido }}
$$

d: densidade relativa

pesoar: peso da amostra no ar

pesoagua: peso da amostra mergulhada em água, menor que peso $\mathrm{ar}_{\text {ar }}$ devido à ação do empuxo

dllquido: densidade do líqüido no qual é mergulhada a amostra, aproximadamente 1 para água destilada a temperatura ambiente

O equipamento utilizado consistiu en balança analítica Ohaus Analytical Plus e Kit para Determinação de Densidade, ambos pertencentes ao Laboratório de Química/ICP do DMG-IG-USP.

\section{III.G.4. Espectroscopia de absorção no infravermelho}

$\mathrm{Na}$ espectroscopia de absorção no infravermelho, a obtenção do espectro envolve a passagem de um feixe de radiação infravermelha através da amostra e a observação dos mínimos de transmissão, que correspondem a absorções causadas pela vibração de moléculas e grupos de átomos na estrutura cristalina do material (McMillan 1985).

Como a técnica pode ser não destrutiva, é de grande utilidade no estudo de materiais gemológicos. No entanto, os equipamentos disponíveis para este trabalho exigiram a preparação das amostras na forma de plaquetas de $0,8 \mathrm{~mm}$ de espessura polidas em ambas as faces. 
Os espectros de infravermelho foram obtidos pelo $\mathrm{Dr}$. U. Henn, utilizando equipamento Perkin Elmer da Associação Gemológica Alemã, em Idar-Oberstein.

\section{III.G.5. Catodoluminescência}

Catodoluminescência é o nome dado ao fenômeno de luminescência em resposta à excitação por um feixe de eletrons (Marshall 1988).

No entanto, como a energia aplicada pelo feixe de eletrons pode ser bastante elevada em relação à radiação visível ou mesmo ultravioleta, a catodoluminescência permite a observação de estruturas e texturas normalmente não identificáveis por meio da petrografia óptica convencional, tais como zoneamento, sobrecrescimentos, etc.

Embora muitas observações ainda restrinjam-se apenas a uma descrição qualitativa da cor e dos padrões de zoneamento observados, a acoplagem de um espectrofotômetro permite a utilização da catodoluminescência como técnica de identificação, pois o espectro obtido é típico de cada material e da distribuição de determinadas impurezas, denominadas de elemento ativador.

Neste trabalho são apresentados espectros obtidos pelo Dr. A. M. van den Kerkhof, da Universidade de Göttingen, utilizando equipamento TRIAX-320. O material foi preparado na forma de plaquetas de $0,5 \mathrm{~mm}$ coladas em lâminas de vidro.

Também foi analisada uma amostra de material sintético no Laboratório de Microscopia Óptica do DMG-IG-USP, com o equipamento Luminoscope ELM-3R, operado pelo Prof. lan McReath.

\section{III.G.6. Parâmetros de cela unitária}

Parâmetros de cela unitária foram determinados em amostras de crisoberilo, tanto da variedade comum quanto olho-de-gato e alexandrita.

As análises foram realizadas no Laboratório de Difratometria de Raios $X$ do IG-USP, utilizando-se equipamento Siemens D5000 e método do pó, tendo silício como padrão interno. No tratamento dos dados empregou-se o programa CelRef. 


\section{III.G.7. Composição química}

No presente trabalho, devido às dimensões geralmente pequenas dos cristais de crisoberilo, a microssonda eletrônica mostrou-se a técnica mais adequada para a análise química do material, permitindo também a verificação da existência de zoneamentos e a identificação de eventuais inclusões sólidas presentes.

A técnica também foi empregada na análise de determinadas fases minerais presentes nas litologias aflorantes na área de estudo.

Foi utilizado equipamento JEOL modelo JXA-8600, pertencente ao Laboratório de Microssonda Eletrônica do IG-USP. As condições de operação foram $15 \mathrm{kV}$, corrente de $20 \mathrm{nA}$, diâmetro do feixe igual a $5 \mu \mathrm{m}$ nas análises de WDS e $1 \mu \mathrm{m}$ nas análises por EDS.

\section{O MINERAL CRISOBERILO}

O nome crisoberilo provém do grego, significando berilo dourado (Palache et al. 1944). Porém, tanto o nome crisoberilo, que acabou prevalecendo, como o termo crisólita, que já era utilizado no Brasil desde o século 17, referiam-se na antigüidade a outros minerais, provavelmente berilo dourado e topázio (Atencio 1999) ou olivina.

O mineral foi primeiramente identificado por Werner (1789 apud Atencio 1999) e analisado por Klaproth (1795 apud Seybert 1824), que utilizou provavelmente material proveniente do Brasil.

No entanto, a presença do elemento Be só foi reconhecida por Seybert (1824), que se referia a ele através do termo corrente na época - Glucina.

\section{IV.A. Propriedades Físicas}

O mineral crisoberilo $\left(\mathrm{BeAl}_{2} \mathrm{O}_{4}\right)$ cristaliza-se na classe $2 / \mathrm{m} 2 / \mathrm{m} 2 / \mathrm{m}$ do sistema ortorrômbico, geralmente na forma de cristais de hábito tabular segundo $\{001\}^{\star}$. São muito comuns também indivíduos de aparência pseudo-hexagonal devido

\footnotetext{
"Com relaçăo à orientação dos eixos cristalográficos, segue-se aqui a convençăo adotada no sistema JCPDS, onde $a>b>c$.
} 
à geminação cíclica, com planos de composição paralelos a $\{310\}$ (Klein \& Hurlbut Jr. 1994) (Fig.IV.1).

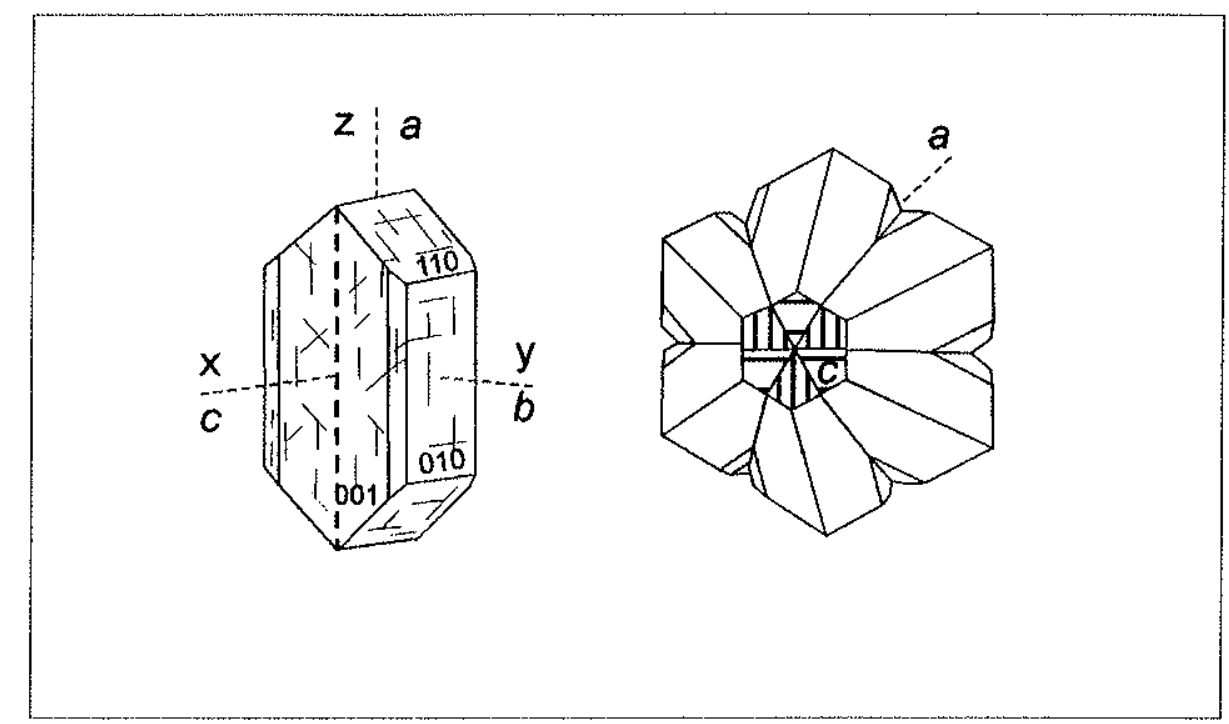

Fig.IV.1: Orientação dos eixos ópticos e cristalográficos do crisoberilo e geminação cíclica característica (Klein \& Hurlbut Jr. 1994, Trögger 1979).

A estrutura do mineral foi determinada por Bragg \& Brown (1926) e refinada por Farrell et al. (1963): no crisoberilo, que é isomorfo com a olivina, os átomos de $O$ formam um arranjo hexagonal compacto distorcido, onde $1 / 8$ dos interstícios tetraédricos é ocupado por $\mathrm{Be}$ e metade das posições octaédricas acomoda átomos de Al (Fig.IV.2). Essas posições octaédricas podem ainda ser diferenciadas quanto ao tamanho e grau de simetria, ou seja, Al/ ocupa um conjunto de centros de inversão e é apreciavelmente menor que Alll, que por sua vez apresenta plano de simetria $m$ (Farrell et al. 1963).

As propriedades físicas e ópticas do mineral e suas constantes cristalográficas são apresentadas na tabela IV.1. 


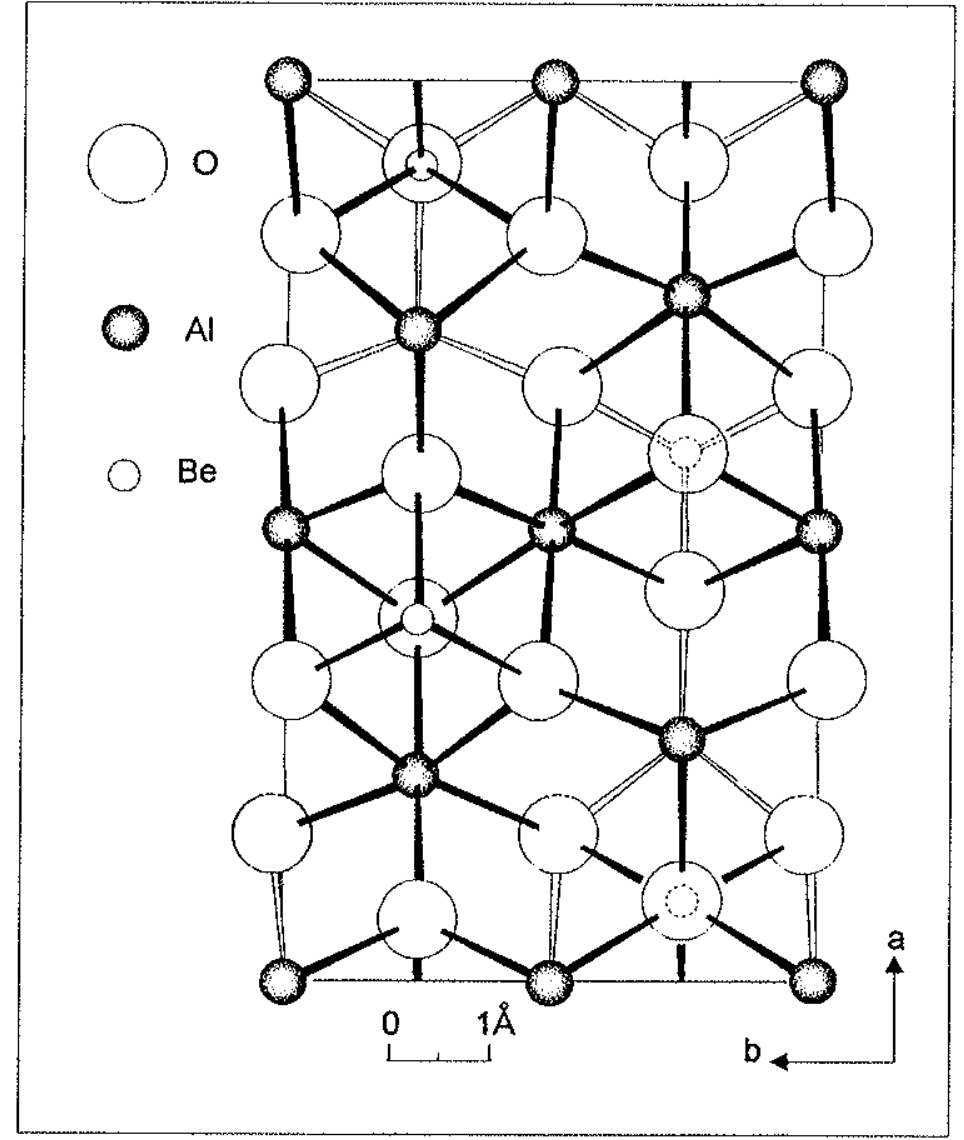

Fig.IV.2: Estrutura do crisoberilo projetada sobre (001) (Farrell et al. 1963).

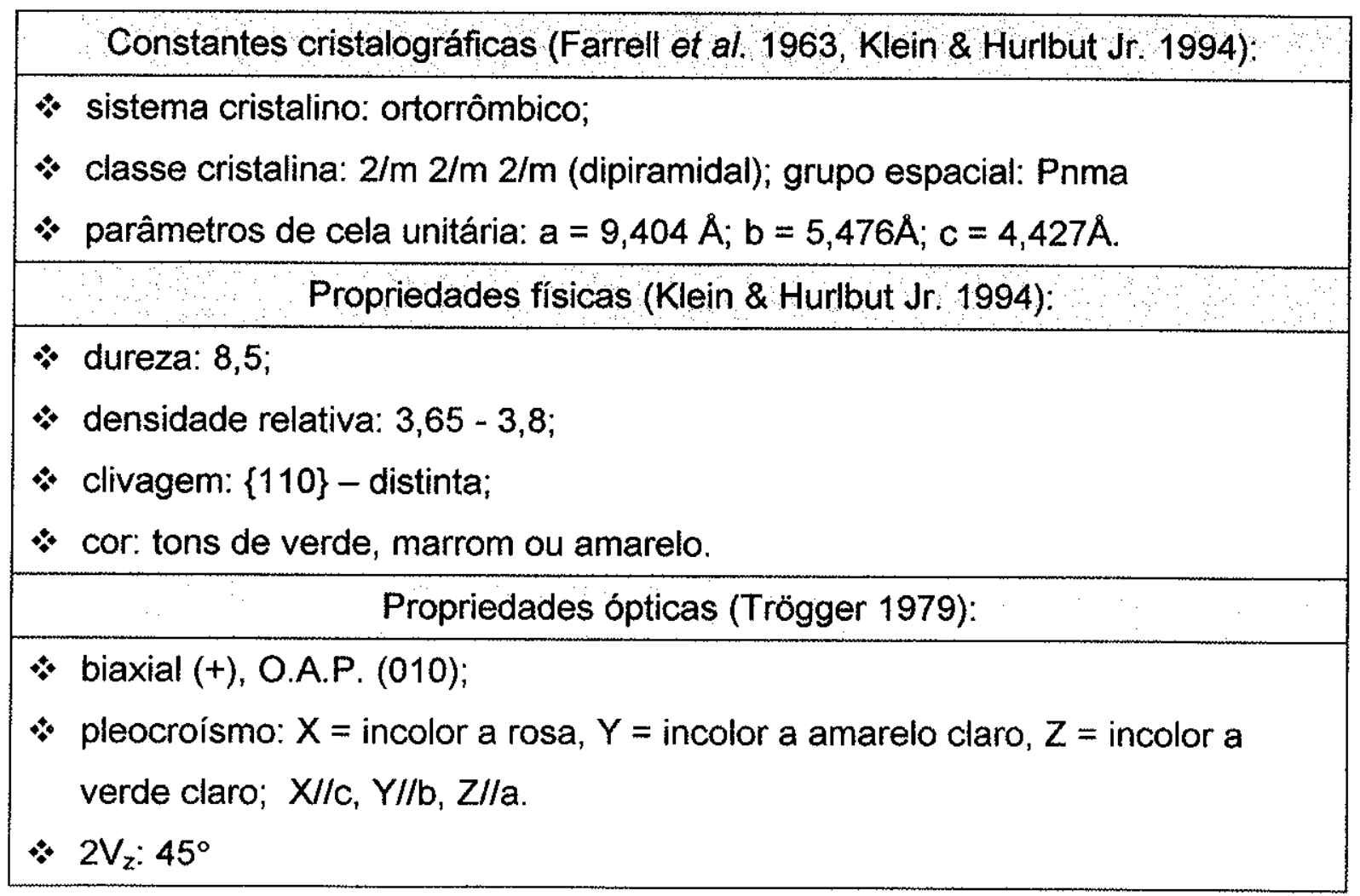

Tab.IV.1: Constantes cristalográficas e propriedades físicas e ópticas do crisoberilo. 
A composição química teórica do mineral, $19,71 \% \mathrm{BeO}$ e $80,29 \% \mathrm{Al}_{2} \mathrm{O}_{3}$, raramente é observada nas análises químicas encontradas na literatura, indicando substituiçōes de $\mathrm{Be}$ e $\mathrm{Al}$ por outros elementos de raio iônico semelhante.

A presença de $\mathrm{Fe}^{3+}$ e $\mathrm{Cr}^{3+}$ substituindo $\mathrm{Al}^{3+}$ em posições octaédricas é responsável pelas cores das variedades crisoberilo amarelo-esverdeado e alexandrita, respectivamente (Farrell \& Newham 1965).

Silício e Titânio também são freqüentemente encontrados, provavelmente substituindo Be e Al.

As presenças de Ga e Sn são justificadas por Otteman et al. (1978) pelas substituições:

$$
\begin{gathered}
\mathrm{Al}^{3+} \rightarrow \mathrm{Ga}^{3+} \\
2 \mathrm{Al}^{3+} \rightarrow \mathrm{Sn}^{4+}+\mathrm{Fe}^{2+}
\end{gathered}
$$

Henn (1985), em um estudo muito completo das propriedades do mineral crisoberilo, analisou 135 amostras das variedades comum e alexandrita provenientes dos principais depósitos conhecidos, além de alexandrita sintética. Na tabela IV.2 encontram-se os teores máximos dos principais elementos analisados pelo autor.

\begin{tabular}{|c|c|c|c|}
\hline elemento (ppm) & crisoberilo comum & alexandrita & alexandrita sintética \\
\hline $\mathrm{Fe}$ & 22.250 & 16.860 & 100 \\
$\mathrm{Ti}$ & 9.560 & 6.550 & n.d. \\
$\mathrm{Si}$ & 4.500 & 3.190 & n.d. \\
$\mathrm{Sn}$ & 3.600 & 2.320 & n.d. \\
$\mathrm{Zn}$ & 1.630 & 1.990 & n.d. \\
$\mathrm{Na}$ & 148 & 167 & 51.9 \\
$\mathrm{Sc}$ & 7,05 & 4,02 & n.d. \\
$\mathrm{Cr}$ & 27,8 & 9.880 & 1.440 \\
$\mathrm{Mn}$ & 12,7 & 40,4 & 0,08 \\
$\mathrm{Ga}$ & 1.967 & 331 & 476 \\
$\mathrm{Ta}$ & 99,7 & 132 & n.d. \\
$\mathrm{V}$ & n.a. & 480 & n.d. \\
$\mathrm{Ir}$ & n.a. & n.a. & $0,5^{\star}$ \\
$\mathrm{Pt}$ & n.a. & n.a. & $96,9^{\star}$ \\
$\mathrm{Ma}$ & & n.a. & $444^{\star}$ \\
\hline
\end{tabular}

Tab.IV.2: Teores máximos em elementos traço encontrados por Henn (1985) em amostras de crisoberilo, alexandrita e alexandrita sintética. Análises por ativação neutrônica e microssonda eletrônica (WDS). n.d.: não detectado; n.a.: não analisado; *: restos do material usado na síntese. 
IV.B. Variedades Gemológicas

São reconhecidas três variedades gemológicas de crisoberilo - crisoberilo comum, olho-de-gato e alexandrita, todas com propriedades ópticas e preços de mercado bastante distintos (Hurlbut Jr. \& Kammerling 1991).

O crisoberilo comum, em tons vivos de amarelo-esverdeado, é a variedade mais freqüentemente encontrada porém de menor valor.

A variedade olho-de-gato distingüe-se pelo efeito de chatoyancy, caracterizado pela presença de uma faixa luminosa móvel de aspecto leitoso e coloração branca, azulada ou esverdeada, causada pela reflexão da luz sobre inúmeras inclusões aciculares paralelas ao eixo cristalográfico a do cristal. O efeito é realçado na lapidação em cabochão, orientando-se a pedra de modo a manter as inclusões paralelas à base do cabochão e ortogonais ao seu eixo maior. No mercado de gemas, quando não acompanhado da espécie mineral, o termo olho-de-gato refere-se somente ao crisoberilo. O termo cimofana é utilizado para designar o material que exibe um brilho difuso ao invés de um "olho" bem definido (Hurlbut \& Kammerling 1991).

A alexandrita corresponde à variedade mais valiosa do crisoberilo, que apresenta como característica a mudança de cor: quando observada em luz natural, a alexandrita mostra-se verde-amarelada, verde-castanho ou verde-azulada, apresentando-se vermelha a violeta sob luz incandescente. Os primeiros achados de qualidade datam de 1830, na Rússia, sendo o nome alexandrita dado em homenagem ao Czar Alexandre II.

Pedras apresentando tanto efeito olho-de-gato quanto de mudança de cor são denominadas alexandrita olho-de-gato.

\section{IV.C. Efeito Alexandrita}

O termo "efeito alexandrita" foi utilizado por White et al. (1967) para designar a capacidade de um material em mudar sua coloração quando observado sob fontes de iluminação diferentes, fenômeno que pode ser explicado através da observação de seu espectro de absorção. 
A cor da alexandrita, assim como do rubi e da esmeralda, é devida à presença de íns $\mathrm{Cr}^{3+}$ em posições octaédricas na estrutura cristalina e, apesar da cor distinta, os três materiais apresentam espectros de absorção semelhantes no visivel, com duas bandas de máxima absorção e duas regiões de máxima transmitância, uma situada entre as duas bandas de absorção e a outra na extremidade de comprimentos de onda maiores (em direção ao vermelho) (Fig.IV.3).

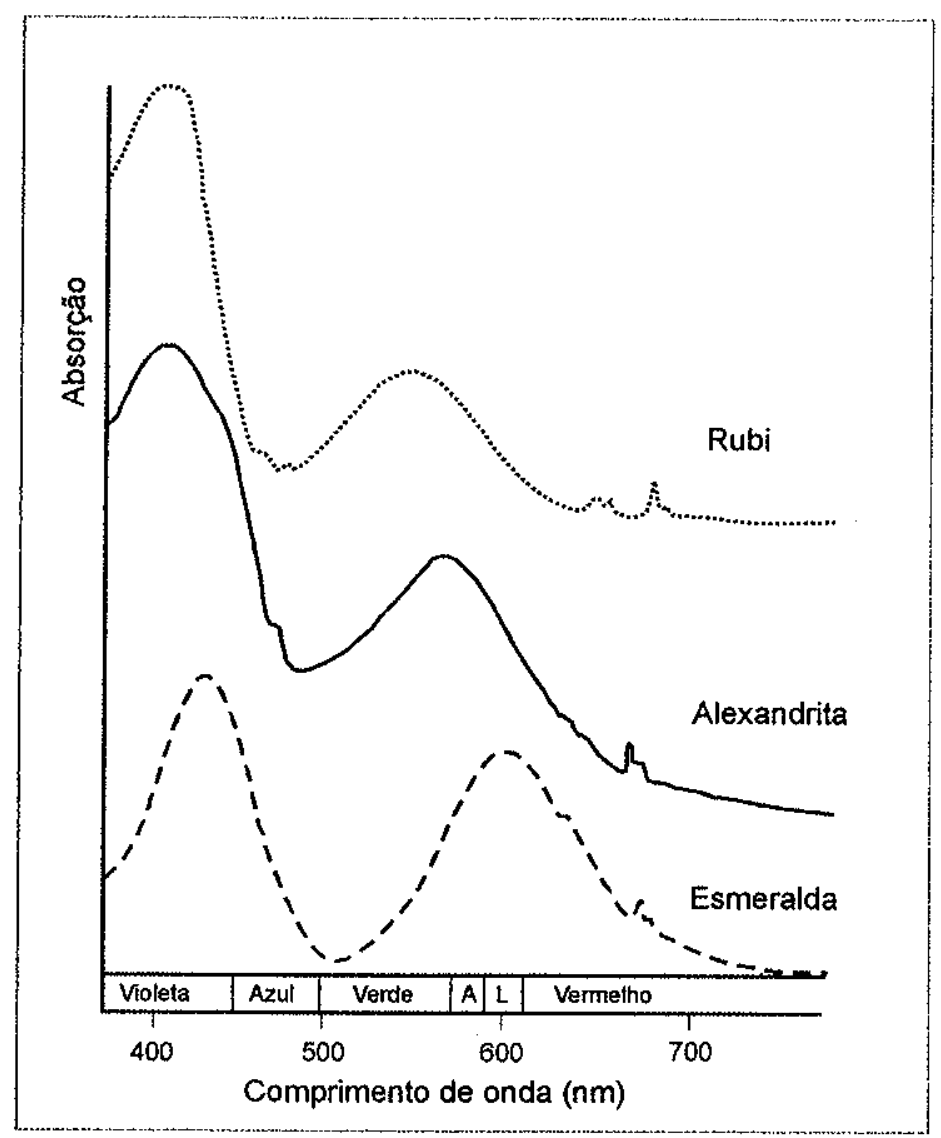

Fig.IV.3: Espectros de absorção do rubi, alexandrita e esmeralda, todos devidos à presença de $\mathrm{Cr}^{3+}$ em coordenação octaédrica. Com o deslocamento das bandas de absorção em direção a comprimentos de onda maiores, a cor varia respectivamente de vermelho para vermelho/verde (efeito alexandrita) e para verde (Fritsch \& Rossman 1987). Materiais naturais provenientes de Burma (rubi), Tanzânia (alexandrita) e Colômbia (esmeralda). A: amarelo; L: laranja.

$\mathrm{Na}$ alexandrita, observam-se duas regiões de mínima absorção situadas a 490 e $670 \mathrm{~nm}$, ou seja, o mineral transmite tanto verde-azulado quanto vermelho. Conseqüentemente, o mineral apresenta-se verde na luz solar, mais rica em 
comprimentos de onda próximos ao verde, para os quais ainda o olho humano tem maior sensibilidade, e vermelho sob luz incandescente, onde o verde praticamente não está presente.

Esse seria portanto um efeito "psico-físico", ou seja, devido a características do olho e cérebro humanos e não a mudanças nas propriedades do material.

Desse modo, o efeito alexandrita pode ocorrer também devido à presença de qualquer outro ion, desde que o espectro resultante apresente as regiões de máxima transmitância próximas aos valores críticos observados na alexandrita.

De fato, o efeito também ocorre em outros materiais, dentre eles coríndon com $\mathrm{V}^{3+}$, espinélio, granada, fluorita com $\mathrm{Sm}^{2+}$ e $\mathrm{Y}^{3+}$, monazita com $\mathrm{Nd}^{3+}$ e coquimbita, dentre outros (Burns 1993).

\section{IV.D. Crisoberilo Sintético}

As primeiras tentativas de obter sinteticamente crisoberilo (a variedade mais comum, sem mudança de cor) são antigas, datando de 1845 e resultando no crescimento de cristais muito pequenos (Kane 1987).

$O$ fato de cristais de crisoberilo sintético com uma pequena quantidade de $\mathrm{Cr}$ apresentarem propriedades interessantes para equipamentos a laser provavelmente acelerou o aprimoramento de técnicas de crescimento em laboratório de alexandrita, motivando experimentos de síntese e o estudo das propriedades do material resultante (Bukin et al. 1981, Guo et al. 1987, dentre outros).

\section{IV.D.1. Processos comerciais de sintese}

Os processos comerciais mais comumente empregados na sintese de alexandrita são os métodos de Fluxo e Czochralski (Cline \& Patterson 1973, Morris \& Cline 1976, Machida \& Yoshihara 1980, Isogami \& Nakata 1986). No que diz respeito à alexandrita produzida por síntese hidrotermal, mais recentemente têm surgido trabalhos destacando a alta qualidade do material (Henn 1992, 1995), porém não são conhecidos detalhes do processo empregado. 
Os métodos de Fluxo e Czochralski apresentam em comum as altas temperaturas envolvidas e as condições anidras, e são possiveis pelo fato de o crisoberilo apresentar fusão congruente.

No método de Fluxo, utilizado por Creative Crystals (EUA), sementes cristalinas de alexandrita sintética ou natural são presas a uma estrutura de platina e levadas a um cadinho contendo uma fusão de molibdato de lítio, $\mathrm{BeO}, \mathrm{Al}_{2} \mathrm{O}_{3}, \mathrm{Fe}_{2} \mathrm{O}_{3}$ e $\mathrm{Cr}_{2} \mathrm{O}_{3}$. O molibdato de lítio recebe o nome de fluxo e tem a função de atuar como solvente dos óxidos constituintes da gema, permitindo sua fusão a temperaturas mais baixas (Read 1991).

No método de pulling ou Czochralski, um cristal em forma de bastão (semente) é rotacionado e soerguido lentamente a partir da superfície do material fundido. A técnica tem sido utilizada por Kyocera Company of Japan para sintetizar alexandrita e alexandrita olho-de-gato (Read 1991).

De acordo com a patente para a produção de alexandrita (Cline \& Paterson 1973), o material pode ser obtido através de ambos os métodos empregando-se as seguintes condições:

\begin{tabular}{|c|c|c|}
\hline & Fluxo & Czochralski \\
\hline Temperatura & $1200^{\circ} \mathrm{C}$ & $1900^{\circ} \mathrm{C}$ \\
\hline $\begin{array}{c}\text { Concentração dos } \\
\text { nutrientes }\end{array}$ & $\mathrm{BeO}+\mathrm{Al}_{2} \mathrm{O}_{3}=4 \%$ no fluxo & \\
\hline $\begin{array}{c}\text { Concentração dos agentes } \\
\text { cromóforos }\end{array}$ & $\mathrm{Cr}: 0,0000685 \%$ & $\mathrm{Cr}: 0,03420$ a $2,568 \%$ \\
$\mathrm{Fe}: 0,7$ a $3,0 \%$ & $\mathrm{Fe}: 0,0699$ a $4,89 \%$ \\
\hline
\end{tabular}

Uma terceira posibilidade de síntese de crisoberilo (variedade alexandrita) envolvendo alta temperatura e condições anidras é o método de Floating Zone SCFZ (Slow Cooling Floating Zone), no qual a porção intermediária de um bastão de alexandrita policristalina (sintered) é aquecida por meio de freqüência de rádio. A temperatura elevada ocasiona a formação de uma zona de fusão que se move lentamente enquanto as duas partes do bastão são rotacionadas. A técnica, empregada pela firma Seiko do Japão, permite a produção de cristais livres de inclusões ou feições de crescimento (Read 1991). 
Todos os três métodos são desenvolvidos em condições de pressão atmosférica.

\section{IV.D.2. Propriedades da alexandrita sintética}

A alexandrita sintética e a natural apresentam índices de refração e densidade praticamente idênticos, motivo pelo qual a determinação das propriedades físicas não tem muita utilidade na distinção entre os dois materiais.

Henn (1992), analisando mais de 60 amostras de alexandrita sintética produzidas na antiga União soviética pelos métodos de Fluxo, Czochralski e Hidrotermal, encontrou valores para o índice de refração situados dentro da faixa observada para material natural (Tab.IV.1), porém mais próximos ao limite inferior.

O mesmo ocorre com os valores de densidade, entre 3,70 e 3,72 (Henn 1992).

A mudança de cor e a fluorescência em raios ultravioleta tendem a ser mais marcantes no material sintético (Anderson 1980), porém não são critérios que devam ser utilizados isoladamente, pois as alexandritas descobertas na Lavra de Hematita caracterizam-se por uma mudança de cor forte, semelhantes às históricas pedras russas (Proctor 1988), enquanto as alexandritas de Lake Manyara (Tanzânia) emitem fluorescência vermelha intensa sob luz UV (Dirlam et al. 1992, Henn 1992).

Inclusões, quando presentes, podem ser diagnósticas da origem, uma vez que refletem $o$ ambiente de formação do material analisado. Pedras naturais caracterizam-se pela presença tanto de inclusões fluidas quanto sólidas, estas últimas de minerais da rocha encaixante que podem inclusive fornecer indicações da procedência da gema. No caso das alexandritas produzidas em laboratório, as inclusões observadas refletem as condições empregadas em cada processo de síntese:

- Método de Fluxo: restos do material utilizado na síntese podem preencher cavidades ou formar arranjos de inclusões metálicas em forma de escamas ou impressões digitais, também descritas como véus e bandeiras (Henn 1992). Ocasionalmente observam-se inclusões metálicas de formato hexagonal, triangular 
ou ainda acicular, identificadas como um metal do grupo da platina, material utilizado na fabricação do cadinho no qual são crescidas as pedras (Fryer 1993);

- Czochralski: turbidez, geralmente no centro do cristal, devido à presença de minúsculas cavidades (Henn 1992), ou ainda estrias curvas visíveis pela imersão da pedra em iodeto de metileno (Fryer 1993);

Síntese Hidrotermal: planos de cavidades alongadas, preenchidas ou não por fluidos (Henn 1992).

No entanto, com o aprimoramento das técnicas de síntese, pedras cada vez mais puras e livres de inclusões têm sido produzidas, tornando ainda mais difícil uma identificação segura.

Nestes casos, a obtenção de espectros de absorção na região do infravermelho tem-se mostrado eficiente ao detectar a presença de $\mathrm{H}_{2} \mathrm{O}$ ou OH no crisoberilo natural, em oposição ao material sintetizado em condições anidras (Stockton \& Kane 1988). Mesmo em se tratando de material sintetizado pelo método hidrotermal, a menor intensidade das bandas de absorção ligadas a $\mathrm{OH}$ constitui um aspecto diagnóstico (Henn 1992).

As diferenças no ambiente de formação entre alexandrita natural e sintética refletem-se também na composição química, como se conclui da análise da tabela IV.2, onde o material sintético apresenta maior pureza em relação ao natural, além de elementos traço peculiares ( $\mathrm{lr}, \mathrm{Pt}, \mathrm{Mo})$.

\section{GEOLOGIA REGIONAL}

Situada a SE do Cráton do São Francisco, respectivamente a NE e E do Quadrilátero Ferrífero e do Espinhaço Meridional, a região entre Itabira e Ferros tem sido contemplada, mesmo que indiretamente, por um grande número de trabalhos, dentre os quais citam-se Dorr \& Barbosa (1963), Herz (1970), Pflug \& Renger (1973), Almeida (1977), Schorscher (1976, 1979, 1988, 1992), Barbosa (1988), Teixeira et al. (1990), Grossi Sad et al. (1990), Dossin et al. (1993), Dussin (1994).

Desenvolvido entre 1946 e 1962, o convênio entre DNPM e U. S. Geological Survey para o mapeamento do Quadrilátero Ferrífero permitiu a 
sistematização do grande volume de informações até então existentes e a formalização de uma coluna estratigráfica que, com as devidas modificações, tem servido de base para muitos dos trabalhos posteriores.

No mapeamento da quadrícula Itabira, Dorr \& Barbosa (1963) reconheceram rochas das "séries" Rio das Velhas e Minas, além de um granito bem mais jovem, indeformado, datado em 475Ma pelo método K/Ar (Hurley 1958 apud Dorr \& Barbosa 1963) e denominado pelos autores de Granito Borrachudos.

Coube a Reeves (1966) o mapeamento das quadrículas de João Monlevade e Rio Piracicaba e a constatação de que, devido à elevação do grau metamórfico em direção a $\mathrm{E}$, a sucessão estratigráfica estabelecida para as áreas central e W do Quadrilátero Ferrifero podia apenas ser reconhecida com dificuldade. Tal fato levou o autor a definir unidades locais provavelmente correlacionáveis àquelas já bem estabelecidas no trabalho de Dorr et al. (1960).

Nos últimos 20 anos, uma grande contribuição para o conhecimento geológico da região tem resultado dos trabalhos de J. H. D. Schorscher, inicialmente sob orientação do Prof. Dr. R. Pflug e posteriormente no acompanhamento de dissertações e teses na área.

\section{V.A. Estratigrafia}

Segundo Schorscher (1992), a margem SE do Cráton do São Francisco apresenta-se constituída principalmente por terrenos granito-greenstone belt de idade arqueana, afetados posteriormente pelo desenvolvimento de faixas móveis proterozóicas. Do terreno granito-greenstone belt fazem parte os terrenos TTG (tonalito-trondhjemito-granodiorito), $\quad$ Granito Borrachudos $e$ a seqüência vulcanossedimentar Supergrupo Rio das Velhas, enquanto as coberturas proterozóicas compreendem os supergrupos Minas, Espinhaço e São Francisco (Fig.V.1).

Os terrenos TTG constituem-se de migmatitos, gnaisses metatéticos e granitóides com composições variando entre leucotonalíticas, trondhjemíticas e granodioriticas, predominando as duas primeiras. A composição modal média inclui plagioclásio $(40-45 \%)$, quartzo $(40-45 \%)$, biotita ( $7 \%$ ou menos), microclínio ( $5 \%$ ou ausente) e acessórios (zircão, allanita, apatita e magnetita). 


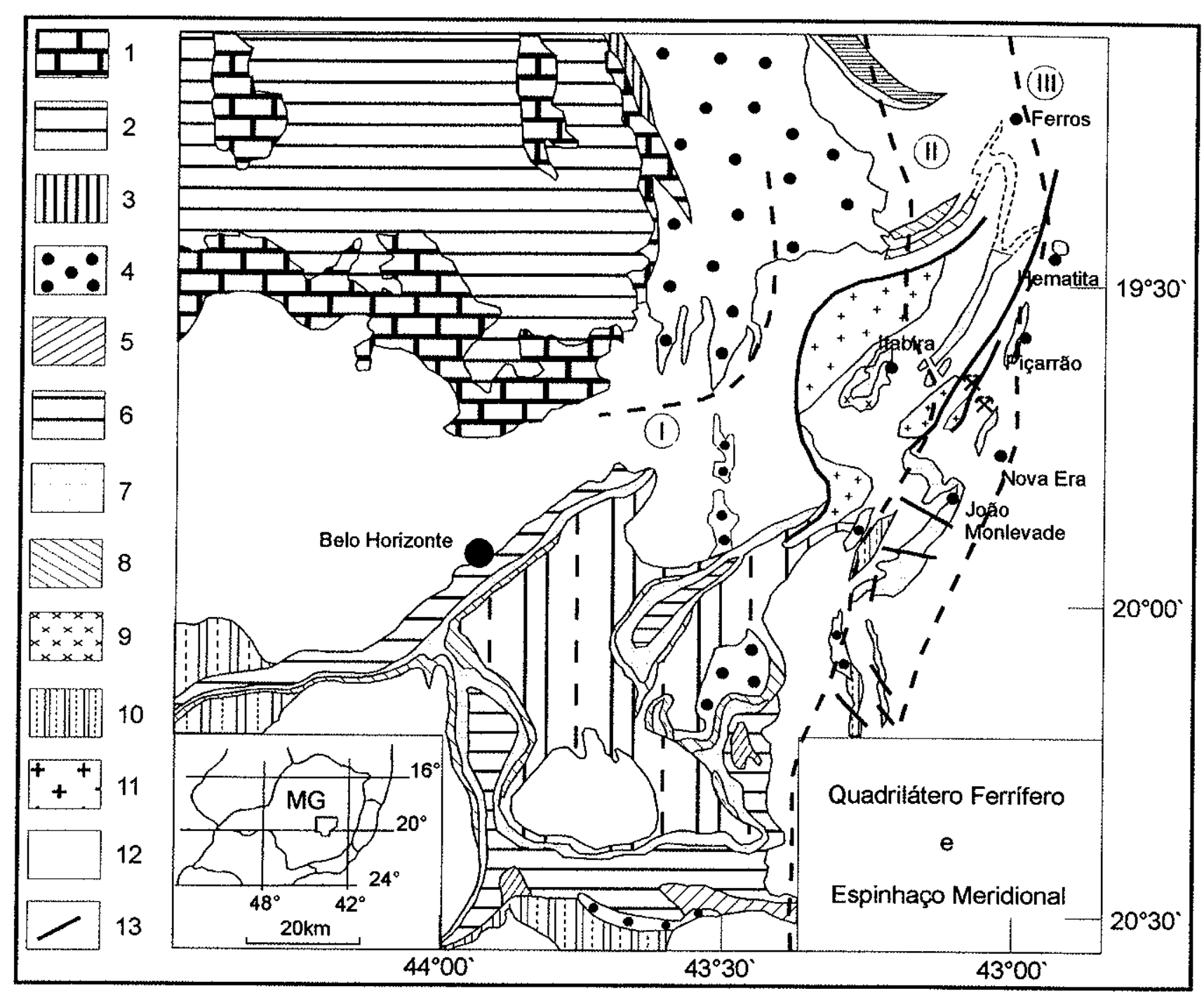

Fig.V.1: Mapa geológico esquemático do Quadrilátero Ferrífero, Serra do Espinhaço Meridional e adjacências (Schorscher 1992).

Supergrupo São Francisco - Gr. Bambuí: (1) rochas carbonáticas, (2) pelíticas e metapelíticas, $\mathrm{Gr}$. Macaúbas: (3) metagrauvacas e ritmitos; Supergrupo Espinhaço: (4) quartzitos e metaconglomerados; Supergrupo Minas - Gr. Itacolomi: (5) quartzitos e metaconglomerados, Gr. Piracicaba: (6) quartzitos, filitos e metagrauvacas, Gr. Itabira: (7) itabiritos e rochas carbonáticas, $\mathrm{Gr}$. Caraça: (8) quartzitos, metaconglomerados e xistos, Seq. de Xistos Verdes: (9) xistos máficos e pelíticos; Supergrupo Rio das Velhas: (1) seqüencia vulcanossedimentar do greenstone belt Rio das Velhas; (11) Granito Borrachudos; (12) terrenos granítico-migmatíticos arqueanos e proterozóicos policíclicos; (13) falhas de empurrăo;

Zonas metamórficas: (I) limite superior de estabilidade do estilpnomelano, (II) aparecimento da estaurolita, (III) aparecimento de sillimanita + feldspato potássico.

жx: Mina de Esmeraldas Belmont e Garimpo de Esmeraldas Capoeirana. 
A sucessão estratigráfica do Supergrupo Rio das Velhas, como apresentada por Schorscher (1992) (Tab.V.1), é reconhecida na região do Quadrilátero Ferrífero, menos afetada por eventos tectono-metamórficos posteriores. Em direção a $\mathrm{E}$ e NE, $\mathrm{O}$ autor descreve continuações regionais do greenstone belt Rio das Velhas, sendo de particular interesse para esta pesquisa as áreas de ocorrência próximas à cidade de João Monlevade (Gnaisse Monlevade) e nas áreas de produção de esmeraldas de Belmont e Capoeirana (Fig.V.1). Nestas regiōes, o autor reconheceu intercalações de cromititos e rochas metaultramáficas com xistos máficos e anfibolitos, considerados típicos do Grupo Nova Lima.

O Gnaisse Monlevade, suposto equivalente de maior grau metamórfico dos xistos e filitos do Grupo Nova Lima, Supergrupo Rio das Velhas, teria como uma das características principais a grande variabilidade textural e composicional, alternando-se entre um gnaisse bandado de granulação fina, quase equigranular, e um augen gnaisse de granulação grossa altamente inequigranular, ocorrendo ainda níveis e lentes de anfibolito, quartzo-mica e estaurolita xisto, quartzito e itabirito (Reeves 1966).

O Granito Borrachudos também recebeu grande atenção por parte de Schorscher (1992), que reconhece sua importância na evolução geológica regional e a sua "relação (genética) com a província de minerais gemas de berílio - esmeralda, água-marinha e alexandrita - compreendida entre Itabira, Nova Era e Hematita".

Primeiramente reconhecido por Dorr \& Barbosa (1963), esse granito foi descrito como uma rocha de coloração cinza-claro, de granulação grossa com megacristais de microclínio de vários centímetros de comprimento, levemente foliada com lineação marcante dada por agregados de biotita alongados segundo $5^{\circ} \mathrm{E}$. Sua composição situa-se entre granito e quartzo-monzonito, com feldspato (45 a $75 \%$, sendo a metade ou mais feldspato potássico), quartzo (30 a 45\%) e biotita (até 12\%), tendo como acessórios fluorita (muito típica), muscovita, granada, epídoto, clinozoisita, turmalina, ilmenita, "leucoxênio", clorita e magnetita. A ausência total de pegmatitos foi destacada pelos autores.

Além da ocorrência-tipo de Itabira, Schorscher (1992) delimitou mais dois corpos que receberam a denominação informal de São Gonçalo do Rio Abaixo e Belmont (Fig.V.1). 


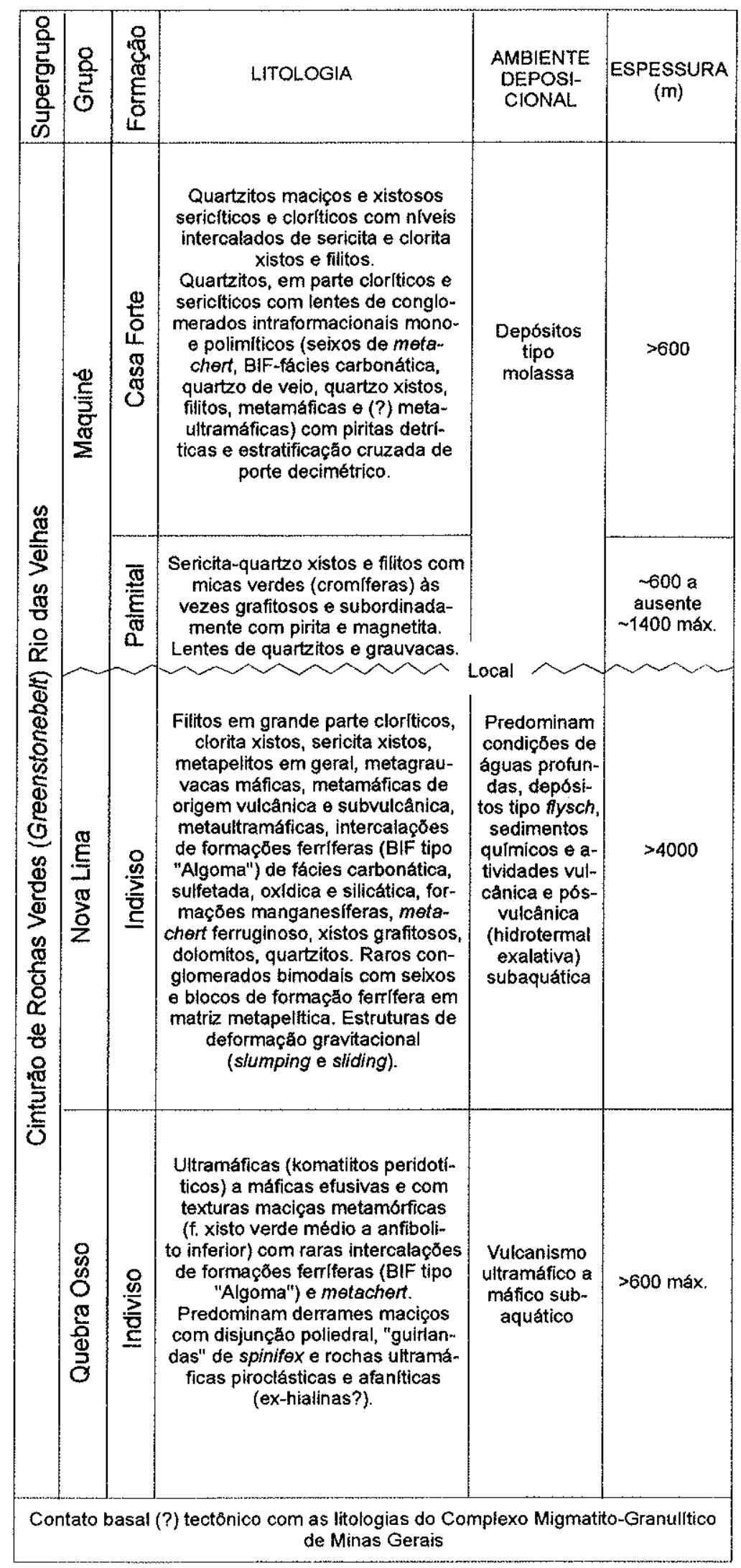

Tab.V.1: Coluna estratigráfica simplificada e litologias principais do Supergrupo Rio das Velhas (Schorscher 1992). 
Trata-se predominantemente de granitóides hololeucocráticos de granulação grossa, cuja característica principal é a estrutura linear dada pela concentração dos minerais máficos em agregados alongados, orientados segundo $E$ W. Composicionalmente predominam álcali-feldspato granitos ricos em elementos incompativeis, com feldspatos alcalinos mesopertíticos (55\%), quartzo (32\%), biotita $(6 \%)$, plagioclásio saussuritizado reliquiar $(2 \%)$, epídoto-clinozoisita-allanita/allanita(Ce) $(1,5 \%)$, fluorita $(1,5 \%)$, zircão, "leucoxênio" e opacos $(0,5 \%$ cada). Ocasionalmente, a fluorita forma concentrações macroscópicas de cor lilás.

As principais áreas de ocorrência do Supergrupo Minas constituem o Quadrilátero Ferrífero e os Distritos Ferríferos de Itabira e João Monlevade, além de continuações menores nas regiões de Nova Era, Piçarrão, Hematita e Ferros (Fig.V.1).

A estratigrafia reconhecida por Schorscher (1992) na região de Itabira encontra-se na tabela V.2, embora o autor destaque a existência ainda de controvérsias sobre a estratigrafia e evolução tectônica do supergrupo.

Na região estudada por Schorscher (1992), o Supergrupo Espinhaço tem sua presença restrita à porção meridional da Serra do Espinhaço e a restos de erosão na região do Quadrilátero Ferrífero.

\section{V.B. Evolução Geológica}

No modelo proposto por Schorscher (1992), a evolução policiclíca da região inicia-se no Arqueano com a formação das rochas TTG por retrabalhamento de crosta siálica, seguindo-se a deposição e orogênese do Greenstone Belt Rio das Velhas e a formação do Granito Borrachudos.

A formação das rochas do Complexo Campo Belo (SW do Quadrilátero Ferrifero) entre aproximadamente 3380 e 3100Ma (Teixeira et al. 1996) pode ser indicativa da idade de constituição do embasamento TTG na região a leste de Itabira.

Idade Rb-Sr de 2652 199 Ma obtida por Teixeira et al. (1990) em um migmatito ao sul da cidade de Santa Maria de Itabira representa provavelmente o retrabalhamento da crosta siálica no Arqueano.

No Proterozóico Inferior têm lugar a deposição dos supergrupos Minas e Espinhaço, considerados penecontemporâneos por Schorscher (1992), e a 
orogênese pós-Minas/Espinhaço que constitui-se no principal evento metamórfico da região.

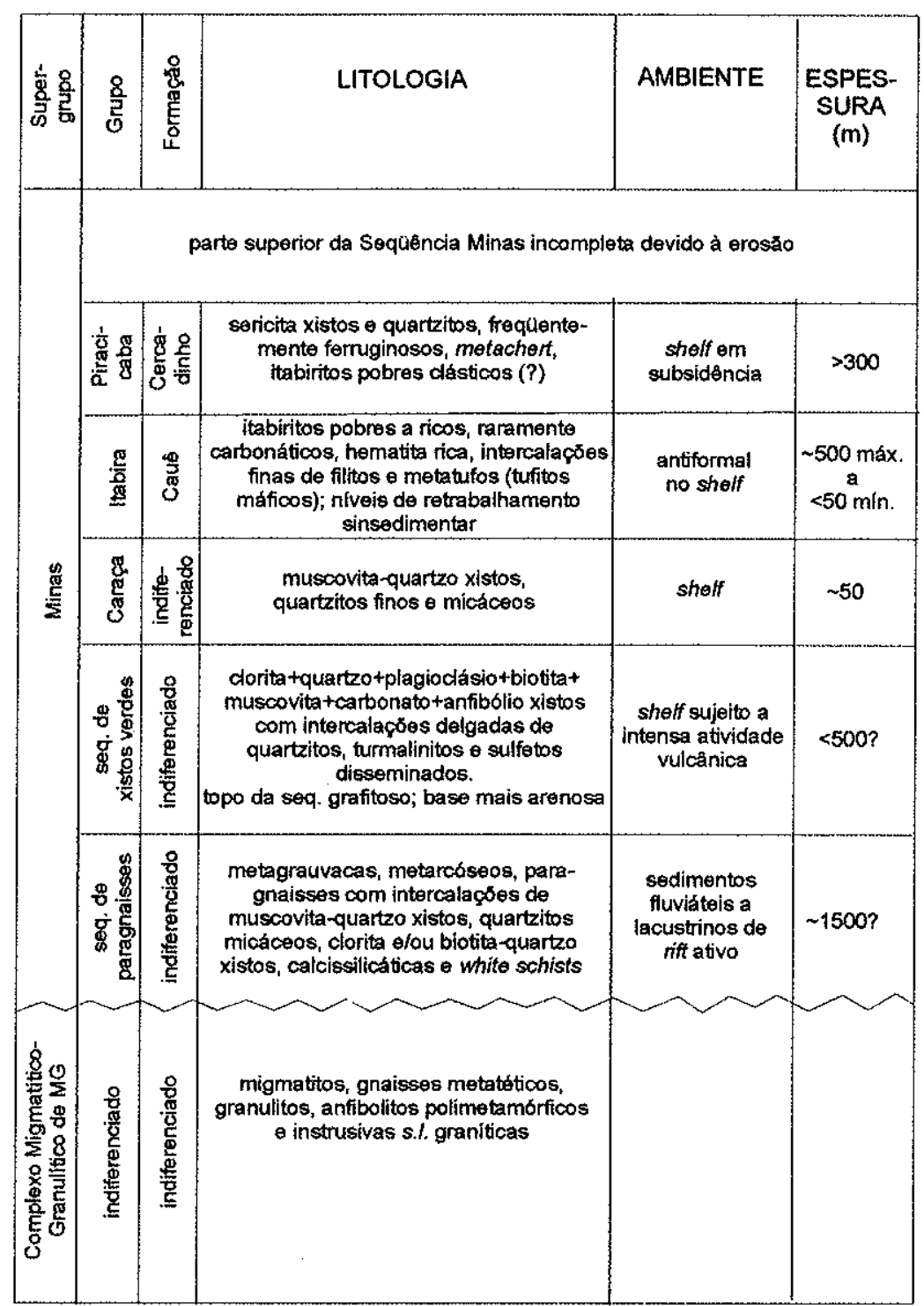

Tab.V.2: Coluna estratigráfica simplificada e litologias principais do Supergrupo Minas no Distrito Ferrífero de Itabira (modificado por Schorscher 1992 de Dorr 1969, Schorscher 1975 e Schorscher \& Guimarães 1976).

Idades correlacionáveis a esse evento foram obtidas por Rettinger (1997) na regiäo entre Acaiaca e Dom silvério (ao sul de Nova Era). A partir de inclusões de monazita em granadas de rochas metapelíticas, o autor obteve idades entre 1977 e $1903 \mathrm{Ma}$, que foram consideradas como idades preservadas do pico do metamorfismo. 
A intensidade desse metamorfismo foi crescente de $W$ para $E$, desde fácies xisto verde inferior até anfibolito superior/hidrogranulito (Schorscher 1992), resultando na disposição das isógradas indicadas na figura V.1. Resultados geotermobarométricos obtidos por Rettinger et al. (1996) nos arredores da cidade de Nova Era indicam condições de temperatura e pressão respectivamente ao redor de $640^{\circ} \mathrm{C}$ e 5,5-6,0kbar.

No Proterozóico Superior observa-se a deposição do Supergrupo São Francisco e sua deformação durante o Ciclo Brasiliano.

Neste contexto, será discutida a gênese do Granito Borrachudos, devido à sua relevância face às mineralizações beriliferas presentes na região.

Schorscher (1992) os considera granitóides orogenéticos sintectônicos, formados pela infiltração de fluidos ao longo de zonas de cisalhamento profundas e sua interação metassomática principalmente com as rochas TTG. As características desses fluidos - teores elevados em $\mathrm{K}$ e outros elementos incompativeis, $\mathrm{F}$ e $\mathrm{CO}_{2}-$ teriam imposto ao Granito Borrachudos propriedades mineralógicas e geoquímicas típicas de granitóides tipo A ou granitos magmáticos peralcalinos.

As condições estimadas pelo autor, $P_{f}=2,0-3,5 k b, P_{\text {sol }}=4-6 k b a r$ e $\mathrm{T}=400( \pm 50)^{\circ} \mathrm{C}$, seriam condizentes com profundidades em torno de 15 a $25 \mathrm{~km}$ e ambiente hidrotermal em sistema semi-aberto.

Além dos três corpos de Granito Borrachudos representados na figura V.1, Schorscher (1992) reconheceu a presença de granitóides deformados, sintectônicos em relação ao evento pós-Minas/Espinhaço, dispostos segundo uma faixa de direção NE passando, no mínimo, por João Monlevade, Nova Era, Piçarrão e Hematita. Após estudos mineralógicos e geoquímicos, o autor concluiu que estes granitóides deformados constituem produtos de retrabalhamento metamórfico e textural do Granito Borrachudos.

Drumond (1985) também havia representado esses corpos de rochas granito-gnáissicas, enfatizando a distinção entre os do tipo Borrachudos e os granitognaisses produtos de retrabalhamento, sem no entanto posicioná-los na evolução geotectônica da área. O autor delimitou os corpos Peti, Itabira, Antônio Dias, Piçarrão, Itauninha, Esmeraldas de Ferros, Carmésia e Dores de Guanhães. Os dois primeiros correspondem aos granitóides Borrachudos definidos por Dorr \& Barbosa (1963) e denominados informalmente por Schorscher (1992) de corpos São Gonçalo 
do Rio Abaixo e Itabira, enquanto a porção meridional do corpo Piçarrão corresponde possivelmente ao corpo Belmont de Schorscher (1992).

Vieira (1985) também delimitou pequenos corpos de "granitos" a $\mathrm{N}$ de Guanhães, novamente sem indicar sua posição na evolução da área, mas destacando sua potencialidade para mineralizações pegmatíticas.

Posteriormente, Grossi Sad et al. (1990), com base em trabalho de mapeamento desenvolvido para a Companhia Vale do Rio Doce nos distritos de Itabira e Guanhães, propuseram a denominação de Suíte Borrachudos para um conjunto de seis corpos de rochas granitóides observadas na região (Fig.V.2), que engloba os três corpos típicos de Granito Borrachudos mais os granitóides delimitados por Drumond (1985) e Vieira (1985).

Vários trabalhos têm surgido mais recentemente tendo como objeto os granitóides da Suite Borrachudos, dentre eles Dossin et al. (1993), Dussin (1994), Fernandes et al. (1994, 1995).

Fernandes et al. (1994), a partir de dados químicos de elementos maiores, traços e terras raras em amostras da Suíte Borrachudos (ocorrências de Dores de Guanhães, Itauninha, Goiabas, Sabinópolis e Itabira - figura V.3), puderam classificá-los inequivocamente como granitos do tipo $\mathrm{A}$ alcalinos e anorogênicos originados de rochas crustais. Os autores ressaltam a grande uniformidade em termos de mineralogia, textura e padrão de distribuição de terras raras, com exceção da amostra proveniente do corpo de Itabira.

No entanto, observam-se ainda divergências entre os resultados obtidos pelos diversos autores no estudo de corpos distintos dentro da Suíte Borrachudos.

Desse modo, enquanto Schorscher (1992), a partir de evidências de campo, admite idade arqueana para o Granito Borrachudos da região de Itabira, a idade de 1.729 $14 \mathrm{Ma}$, obtida por Dossin et al. (1993) em zircão (método da evaporação direta sobre o filamento) do Plúton São Félix da Suíte Borrachudos, próximo a Sabinópolis (Fig.V.3), levou Dussin (1994) a associar a intrusão desses granitóides no Proterozóico Médio aos estágios iniciais (rift) da abertura da bacia de deposição do Supergrupo Espinhaço. 


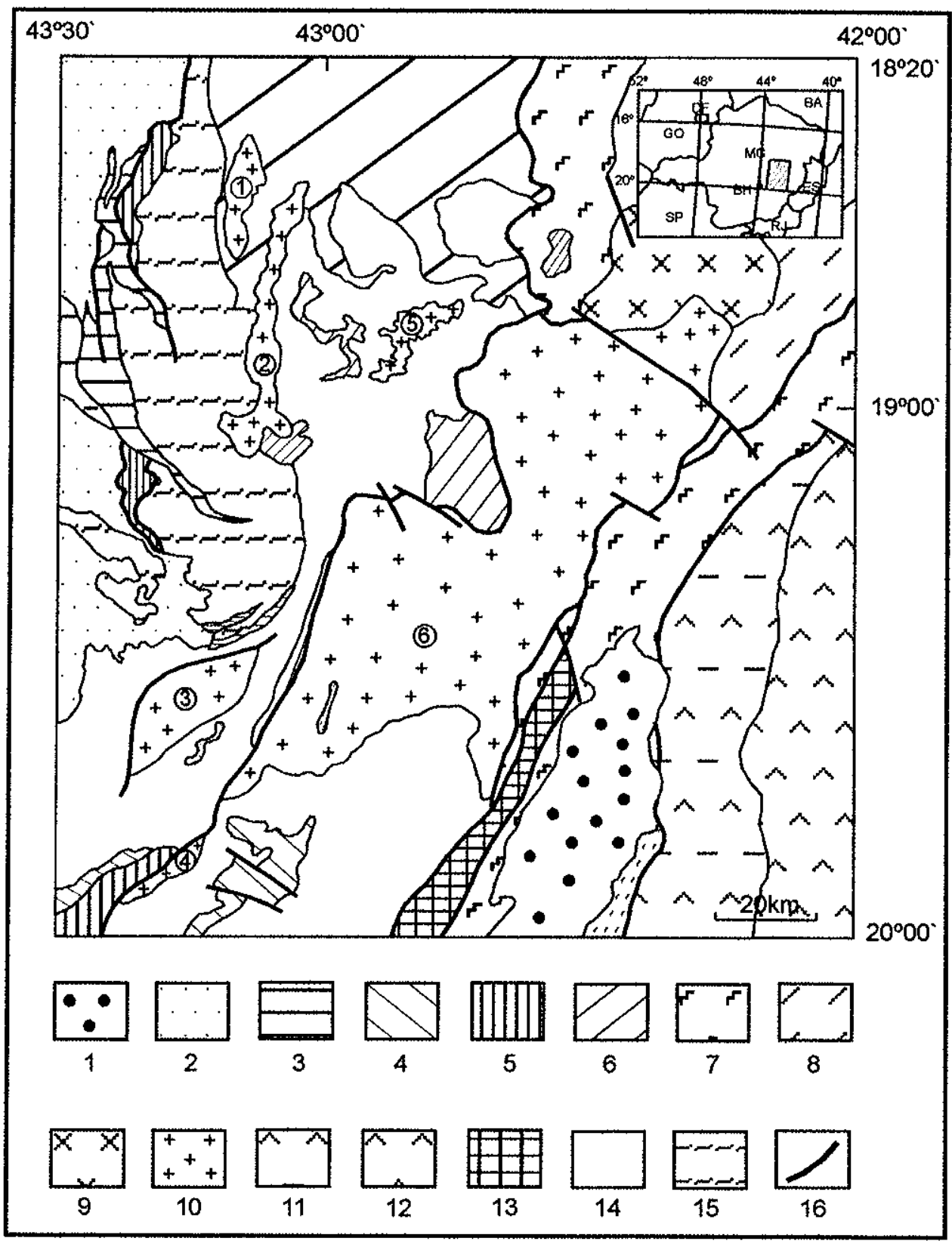

Fig.V.2: Mapa geológico do bordo sudeste do Cráton do São Francisco (Grossi Sad et al. 1990).

1: Quaternário e Terciário; 2: Grupo Espinhaço; 3: Seqüência Serra da Serpentina; 4: Supergrupo Minas; 5: Supergrupo Rio das Velhas e Seqüência Rio Mata Cavalo; 6: Grupo Guanhães; 7: Grupo Rio Doce (gnaisses); 8: Grupo Rio Doce (xistos); 9: Granitos do Rio Doce; 10: Suíte Borrachudos (1) São Félix, (2) Senhora do Porto, (3) Itabira, (4) Peti, (5) Morro do Urubu, (6) Açucena); 11: Complexo Juiz de Fora (milonito gnaisses, etc.); 12: Complexo Juiz de fora (charnockitos); 13: Grupo Dom Silvério; 14: Suite Guanhães; 15: Milonito gnaisses; 16: Falhas verticalizadas e de empurrão. 


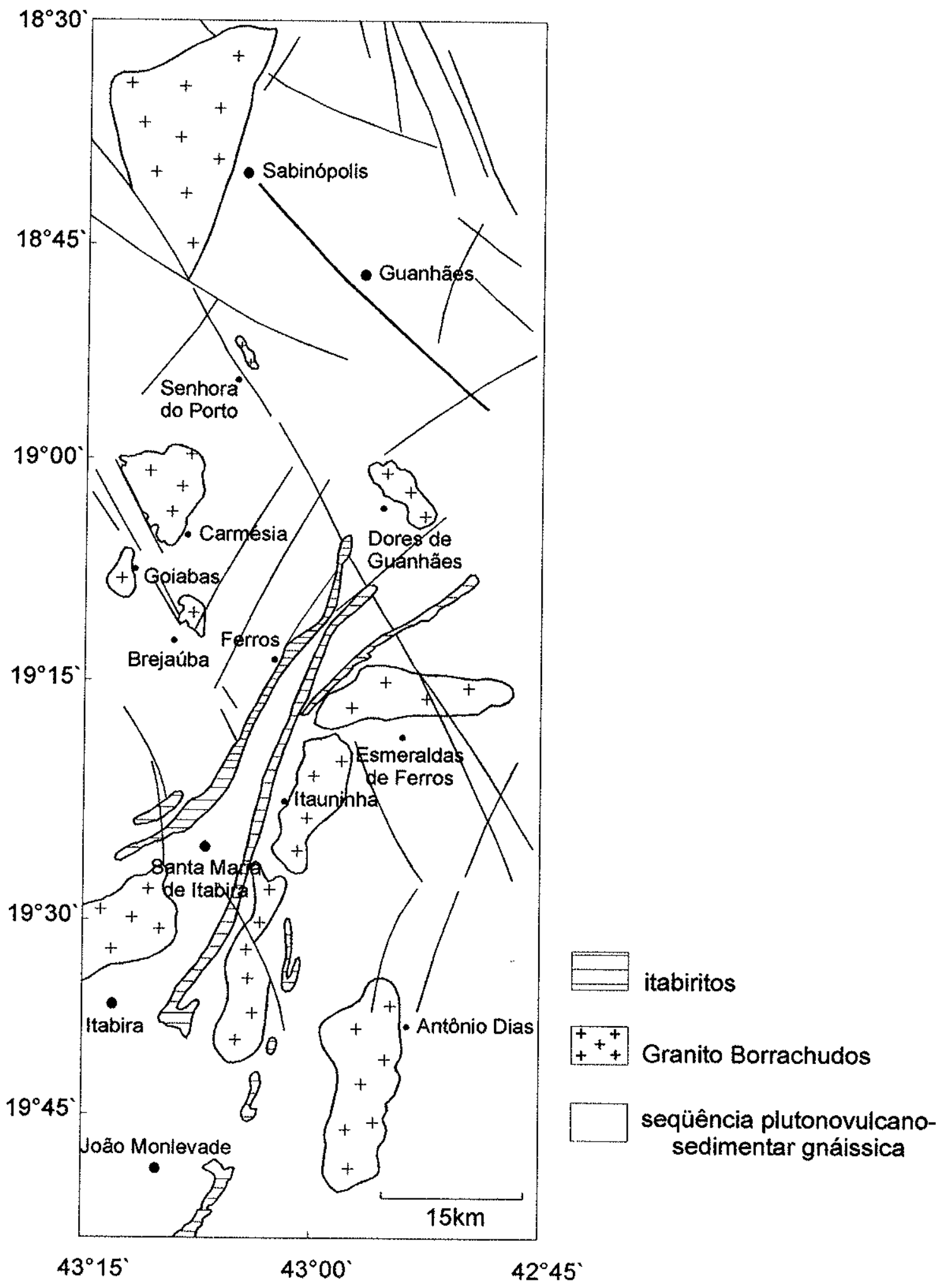

Fig.V.3: Mapa geológico simplificado da região central do Estado de Minas Gerais, destacando as ocorrências de Granito Borrachudos (adaptado por Fernandes et al. 1994 de Drumond 1985 e Vieira 1985). 
Posteriormente, Fernandes et al. (1995) apresentaram uma estimativa das condições de cristalização para o Maciço Granítico Dores de Guanhães, também considerado como pertencente à Suíte Borrachudos. Utilizando-se das composições químicas de anfibólios e feldspatos, os autores propõem condições de $\mathrm{P}$ e $\mathrm{T}$ de, respectivamente, $6,2 \mathrm{kbar}$ e $840^{\circ} \mathrm{C}$, bem acima portanto das condições estimadas por Schorscher (1992) a partir de seus estudos no corpo de Itabira.

Até o momento, fica muito evidente a diversidade de opiniões entre os autores que se dedicaram e se dedicam ao estudo das rochas denominadas Borrachudos, fato que vem ressaltar a necessidade de estudos adicionais que permitam a caracterização e posicionamento no quadro da evolução geológica regional de cada corpo incluído na Suíte. Isso evitaria a comparação entre rochas formadas provavelmente em contextos diferentes.

Mesmo em se tratando das áreas de ocorrência-tipo as divergências persistem. Assim, Chemale Jr. (1987), com base em estudos petroquímicos e estruturais no Granito Borrachudos (corpo de Itabira) e no Granitóide Santa Bárbara (corpo São Gonçalo do Rio Abaixo de Schorscher 1992), considerou-os como produto da cristalização de magmas alcalinos anidros, cuja colocação teria ocorrido em ambiente anorogênico, antes do principal evento deformacional da área.

\section{V.C. Mineralizações Beriliferas}

Drumond (1985) destaca a região entre Itabira e Ferros como potencialmente prospectável para a produção de minerais beriliferos, não apenas esmeralda e alexandrita como também água-marinha.

Nos depósitos de esmeralda da Mina Belmont e do Garimpo de Capoeirana, localizados respectivamente nos municípios de Itabira e Nova Era e onde alexandrita ocorre apenas eventualmente, foram realizados estudos pormenorizados, primeiramente por Souza (1988) e Souza et al. (1992) e posteriormente por Machado (1994, 1998).

Os estudos de Souza (1988) e Souza et al. (1992) permitiram reconhecer o controle estrutural exercido por falhas de empurrão de direção aproximada NS, que colocam em contato rochas gnáissicas de composição granítica (Granito 
Borrachudos) e xistos ultramáficos da seqüência vulcanossedimentar. Os autores atribuem a fonte do $\mathrm{Be}$ a corpos pegmatíticos geneticamente ligados ao Granito Borrachudos.

As paragêneses minerais observadas por Souza et al. (1992) indicam fácies xisto verde alto a anfibolito médio, com evidências de metassomatismo local, enquanto dados microtermométricos em esmeralda forneceram valores de $P$ entre 2 e $2,75 \mathrm{kbar}$ e T entre 450 e $650^{\circ} \mathrm{C}$.

Estudos posteriores de Machado $(1994,1998)$ confirmaram o controle estrutural das falhas de empurrão. No entanto, segundo esta última autora, o processo mineralizante estaria relacionado à formação do Granito Borrachudos como admitida por Schorscher (1992), ou seja, circulação de fluidos ricos em álcalis e especialmente em Be através de zonas de cisalhamento profundas, causando metassomatismo nas rochas metaultramáficas e da associação TTG. Esse processo teria ocorrido no final do Arqueano, porém no Garimpo de Capoeirana condições de metamorfismo de fácies anfibolito médio/superior teriam sido atingidas no Proterozóico, permitindo a geração de pegmatitos que, quando intrusivos em rochas metaultramáficas, seriam os responsáveis pelas ocorrências de alexandrita.

Pegmatitos portadores de água-marinha foram intensamente estudados por Marciano (1995) e datados por Marciano et al. (1993) pelo método K/Ar em muscovita, fornecendo idades próximas a 520Ma. Valor semelhante $(531 \pm 22 \mathrm{Ma})$ foi obtido por Bilal et al. (1995) em monazitas não alteradas.

Considerando-se essas idades e a idade arqueana admitida por Machado $(1994,1998)$ para as mineralizações de esmeralda de Belmont e Capoeirana, parece ter havido duas fases importantes, separadas por um intervalo de tempo considerável, de mobilização de fluidos ricos em Be.

\section{GEOLOGIA DA ÁREA}

A feição de maior destaque é representada por "paredões" de rocha granito-gnáissica em oposição a áreas de altitudes baixas, ao redor de $500 \mathrm{~m}$. As rochas granito-gnáissicas constituem dois corpos alongados de grande expressão, o primeiro de direção aproximadamente $\mathrm{N}-\mathrm{S}$, entre as cidades de Nova Era e Ferros, e 
- segundo de direção E-W próximo à localidade de Esmeraldas de Ferros, correspondendo provavelmente ao que Schorscher (1992) considerou como corpos de Granito Borrachudos retrabalhados pelo evento pós Minas/Espinhaço. Sua distribuição espacial corresponde aproximadamente aos corpos de Esmeraldas de Ferros e Itauninha delimitados por Drumond (1985) (Fig.V.3).

No restante da área afloram litologias variadas, provavelmente restos dos supergrupos Rio das Velhas e Minas, tais como rochas metaultramáficas, anfibolitos, paragnaisses, formações ferríferas, xistos e quartzitos, freqüentemente muito alteradas e com suas estruturas primárias obliteradas.

\section{VI.A. Unidades Litológicas}

\section{VI.A.1. Ortognaisse Açucena}

Aos corpos de Granito Borrachudos retrabalhados pelo evento pósMinas/Espinhaço foi dada a denominação informal de Ortognaisse Açucena devido à distribuição espacial dentro dos domínios da unidade homônima definida por Grossi Sad et al. (1990).

Esta unidade está representada na localidade de Esmeraldas de Ferros por um Ortognaisse com Anfibólio e Biotita que, com a progressão da deformação, transforma-se em Ortognaisse com Biotita ( \pm fluorita), este último predominando nos arredores de Hematita e Itauninha.

\section{VI.A.1.a. Ortognaisse com Anfibólio e Biotita}

Em amostra de mão apresenta coloração cinza, rosada ou amarelada e granulação média a grossa (3 a $6 \mathrm{~mm}$ ) (Prancha 1-A), observando-se gradações entre uma rocha com aspecto de granito gnaissificado, com minerais máficos constituindo aglomerados de formato alongado, e tipos mais orientados, com bandamento pronunciado dado por níveis finos e descontínuos de minerais máficos, localmente mais espessos.

Essas gradações observadas macroscopicamente também são reconhecidas em lâmina. Os tipos menos orientados apresentam textura 
granolepidoblástica inequigranular, com biotita, anfibólio e acessórios (zircão, allanita, opacos, apatita e fluorita) formando aglomerados alongados (Prancha 1-B) em meio a grãos anedrais de feldspato potássico, plagioclásio e quartzo. A orientação é pouco pronunciada, reconhecida na disposição dos aglomerados máficos e de alguns poucos grãos alongados de feldspato potássico.

Nas rochas mais gnaissificadas, a textura é granolepidoblástica inequigranular orientada e a estrutura bandada, com os aglomerados de minerais máficos estirados constituindo níveis espessos e descontínuos, em meio a grãos de quartzo bastante alongado e feldspato potássico e plagioclásio levemente alongados. Localmente estão presentes agregados finos de grãos poligonais de quartzo, feldspato potássico (microclínio) e plagioclásio.

O feldspato potássico forma grãos maiores que os demais minerais, levemente alongados, pouco fraturados e micropertíticos com exsoluçōes em forma de vênulas, raramente chegando a mesopertíticos (Prancha 1-C). No entanto, não foram observados os megacristais de mesopertitas de substituição típicos do Granito Borrachudos (Dorr \& Barbosa 1963, Schorscher 1992). A geminação em grade é melhor desenvolvida ao redor de fraturas, pertitas e inclusões de outros minerais, observando-se que o processo de inversão estrutural do polimorfo monoclínico para o triclínico é favorecido pela deformação.

Níveis finos de plagioclásio nas bordas de alguns grãos de feldspato potássico atestam a expulsão da fase albítica da fase potássica hospedeira.

O plagioclásio, de composição albítica $\left(\mathrm{An}_{4-8}\right)$, desenvolve grãos menores que o feldspato potássico e apresenta feições de deformação/recristalização, tais como geminação polissintética pouco visível ou restrita a porções do grão, zoneamento nas bordas coincidindo com o desaparecimento da geminação, recristalização em subgrãos, kink bands e geminação encurvada (Prancha 1-D).

O quartzo constitui grandes grãos alongados, com sinais de deformação e recristalização em intensidades variáveis (extinção ondulante, formação de subgrãos), ou grãos menores recristalizados, poligonais.

Entre os anfibólios predominam grãos anedrais, intersticiais (contornos reentrantes), alongados e orientados, fraturados e menos comumente grãos poligonais, euédricos muito pequenos ou poiquiloblásticos (com inclusões arredondadas de quartzo e plagioclásio). 0 mineral apresenta pleocroísmo intenso 
(amarelo-esverdeado $\rightarrow$ verde-oliva $\rightarrow$ azul-esverdeado), caráter biaxial (-), $2 \mathrm{~V}$ baixo (em torno de $20^{\circ}$, freqüentemente simulando figura uniaxial) e inclusões de microclínio, quartzo, allanita, zircão e apatita.

Freqüentemente observa-se a substituição de anfibólio por biotita (Prancha 1-E):

$$
\text { anfibólio } \rightarrow \text { biotita + quartzo + fluorita }
$$

A biotita contitui plaquetas euédricas, mais espessas quando nos aglomerados ou níveis máficos ou mais delgadas quando isoladas em meio às porções quartzo-feldspáticas, ou ainda plaquetas longas e finas (filamentos) sem orientação, cortando grãos de anfibólio nos aglomerados máficos (Prancha 1-B). O pleocroísmo é forte (castanho-amarelado $\rightarrow$ castanho-esverdeado escuro) e inclusões de zircão são muito numerosas, além de allanita. Uma outra geração de biotita (pleocroísmo: castanho-amarelado claro $\rightarrow$ castanho-avermelhado) está presente, porém em pequena quantidade.

Os minerais acessórios encontram-se preferencialmente próximos aos aglomerados máficos e constituem-se de zircão (gräos euedrais), allanita (grãos euedrais ou arredondados), apatita (grãos ovalados), fluorita (grãos pequenos, intersticiais, ou massas grandes em meio aos aglomerados máficos, mais rara que no Ortognaisse com Biotita), opacos (raros grãos anedrais), titanita (grãos euedrais).

A composição modal permite a classificação dessas rochas como álcalifeldspato granitos (Streckeisen 1976), com feldspato potássico (25 a 40\%), plagioclásio - albita (20 a $35 \%$ ), quartzo (26 a 40\%), anfibólio (1 a 5\%), biotita (1 a $6 \%$ ) e acessórios (menos de $0,8 \%$ ).

\section{VI.A.1.b. Ortognaisse com Biotita ( \pm fluorita)}

O aspecto macroscópico é de um gnaisse rosado de granulação fina a média (1 a $3 \mathrm{~mm}$ ), com biotita disposta em niveis finos (1 a $2 \mathrm{~mm}$ ) descontínuos porém regularmente espaçados, localmente mais espessos sugerindo nódulos máficos estirados. Ocasionalmente podem ser reconhecidos grãos alongados de 
feldspato ou fitas de quartzo, magnetita como raros cristais milimétricos (até $5 \mathrm{~mm}$ ) e niveis quartzo-feldspáticos de granulação grossa.

Em seção delgada observa-se estrutura bandada, com biotita disposta em niveis descontínuos. A textura é granolepidoblástica inequigranular orientada, sendo a foliação dada principalmente pela biotita mas também por grãos alongados de microclínio, plagioclásio e fitas de quartzo; os contatos entre os grãos maiores são irregulares, interdigitados, enquanto grãos menores tendem a ser poligonais.

O microclínio apresenta grande variabilidade textural e granulométrica, desde grãos maiores, ligeiramente alongados, até grãos finos equidimensionais (poligonais), passando por grãos bastante alongados de dimensões intermediárias.

A geminação em grade típica do microclínio é bem desenvolvida, com exceção dos grãos maiores levemente alongados, onde a geminação é ausente ou pouco visivel, melhor desenvolvida ao redor de fraturas e inclusões. Nesses grãos podem ser reconhecidas raras micropertitas (lamelas finas, muito raramente chegando a mesopertitas) e raros níveis finos de plagioclásio nas bordas. A existência de agregados de grãos de microclínio com extinção pouco contrastante (subgrãos) ou com junções tríplices revela tratar-se de recristalização de antigos megacristais.

O plagioclásio, de composição albítica $\left(A n_{6-8}\right)$, constitui grãos anedrais raramente alongados, onde podem ser reconhecidas evidências de deformação/recristalização, tais como geminação polissintética ausente, pouco visível ou restrita a porções do grão, lamelas de geminação encurvadas, geminação de origem mecânica (lamelas interrompidas, com terminação em cunha em direção ao centro do grão), extinção ondulante, kink bands ou recristalização em subgrãos.

Muitos grãos apresentam ainda inclusões vermiformes de quartzo, sugerindo origem a partir da recristalização de antigas mirmequitas.

O quartzo ocorre sob diversas formas, tais como gräos alongados, com extinção ondulante ou recristalização em subgrãos, fitas e grãos menores recristalizados.

As plaquetas subeuedrais de biotita dispostas segundo a foliação apresentam pleocroísmo intenso (castanho-amarelado claro $\rightarrow$ castanho-esverdeado escuro), porém raramente observa-se outra biotita com pleocroísmo diferente 
(castanho-amarelado claro $\rightarrow$ castanho-avermelhado escuro), em orientação oblíqua à foliação da rocha.

Como acessórios encontram-se fluorita (acessório mais freqüente, em grandes grãos intersticiais ou mais raramente pequenos grãos euedrais), zircão (pequenos cristais euedrais a arredondados, zonados), apatita (grãos ovalados), epídoto (grãos pequenos arredondados), titanita (grãos subeuedrais), allanita (bastante alterada/metamictizada) e opacos (magnetita).

A composição modal obtida para essas rochas foi feldspato potássico (23 a $34 \%$ ), quartzo (34 a $43 \%$ ), plagioclásio (19 a $30 \%$ ), biotita (3 a $9 \%$ ), fluorita $(0,1$ a $0,5 \%)$ e acessórios $(0,1$ a $0,5 \%)$, permitindo sua classificação como álcali-feldspato granitos (Streckeisen 1976).

\section{VI.A.2. Supergrupo Rio das Velhas e Supergrupo Minas}

Foram observadas intercalações de espessuras variáveis (decimétricas a métricas) de quartzitos, muscovita quartzitos, quartzo-muscovita xistos, muscovita xistos, biotita xistos, gnaisses, anfibolitos, metaultramáficas e formações ferríferas. Veios quartzo-feldspáticos estão freqüentemente presentes, concordantes com a atitude das rochas ou truncando a foliação, desenvolvendo localmente massas fibrosas de sillimanita.

\section{VI.A.2.a. Rochas metaultramáficas}

A ocorrência de rochas metaultramáficas pôde ser constatada graças à existência de trabalhos subterrâneos em áreas de ocorrências de esmeraldas.

Trata-se de rochas constituídas por proporções variáveis de talco, tremolita/actinolita, antofilita, clorita e flogopita, resultando nos tipos talco-tremolitaantofilita-clorita xisto, antofilita tremolitito ( \pm cromita), antofilita-tremolita-clorita xisto, actinolita-flogopita xisto e flogopitito, além de um hornblendito.

O antofilita tremolitito constitui uma rocha de coloração verde escura, com prismas de antofilita de cor castanho mel de até $1,5 \mathrm{~cm}$ de comprimento, sem orientação, em matriz de granulação fina de cor verde escura e aspecto maciço. 
Em seção delgada, observam-se porfiroblastos não orientados de antofilita em matriz orientada de tremolita prismática, acicular ou em grãos recristalizados (poligonais), além de rara presença de plaquetas finas de clorita (Prancha 2-A). Cromita pode estar presente em concentrações muito variáveis, chegando a até $50 \%$ nos niveis mais ricos.

A antofilita apresenta-se como cristais prismáticos de seção losangular (prisma rômbico), incolores, $2 \mathrm{~V}$ alto e caráter biaxial (-). Esses porfiroblastos de antofilita, pós-cinemáticos, apresentam inclusões de tremolita e truncam a foliação.

Os cristais de tremolita da matriz são levemente pleocróicos (verde pálido $\rightarrow$ castanho-esverdeado), possuem hábito prismático a acicular, $2 \mathrm{~V}$ elevado, ângulo de extinção em torno de $20^{\circ}$ e caráter biaxial (+).

O desenvolvimento de clorita leva à formação de antofilita-tremolita-clorita xisto, onde pode ser observado também talco em pequena quantidade.

Nos garimpos de Córrego das Pedras e Limeira, as mineralizações de esmeralda são hospedadas por um flogopitito de granulação grossa.

Em seção delgada observam-se plaquetas espessas e longas de flogopita, orientadas em sua maioria, quartzo em fitas ou agregados alongados recristalizados, além de minerais opacos de hábito cúbico (ferricromita) e restos de anfibólio verdeazulado (actinolita) (Prancha 2-B).

Constituindo intercalações no flogopitito observa-se um actinolita-flogopita xisto que, em seção delgada, apresenta plaquetas longas e finas de flogopita, orientadas, grãos anedrais de actinolita, intersticiais com bordas retilíneas determinadas pelas faces (001) da flogopita, além de quartzo e opacos (cromita).

\section{VI.A.2.b. Anfibolito}

A presença de rochas anfibolíticas foi constatada em toda a área de estudo, comumente na forma de blocos de rocha semi-alterada em meio a solo vermelho. Ocorrências in situ apresentam-se como intercalações decimétricas a métricas (furo de sonda na área da Lavra de Hematita: espessura mínima de $15 \mathrm{~m}$ ).

O aspecto macroscópico é de um anfibolito de coloração cinza-escuro, granulação fina (1-2mm), com bandamento fino e pouco desenvolvido. Algumas amostras apresentam ainda bandamento composicional melhor desenvolvido, com 
intercalações de niveis de coloração verde (ricos em epídoto) ou quartzofeldspáticos.

O estudo de seções delgadas revelou a predominância de um anfibolito de textura nematoblástica inequigranular orientada, com grãos alongados de hornblenda constituindo o arcabouço da rocha e grãos intersticiais de plagioclásio e quartzo, sendo a titanita o acessório mais freqüente.

A hornblenda constitui grãos alongados e orientados, fortemente pleocróicos (verde-azulado a verde-amarelado ou verde a castanho-esverdeado).

O plagioclásio mostra-se freqüentemente zonado, evidenciando reequilíbrio metamórfico.

Nas proximidades da localidade de Esmeraldas de Ferros, a essa mineralogia somam-se um clinopiroxênio (diopsídio) e a presença de veios quartzofeidspáticos cortando o anfibolito.

Variações composicionais são responsáveis provavelmente pela ocorrência de um anfibolito rico em biotita castanho-avermelhada.

\section{VI.A.2.c. Gnaisse Monlevade}

Macroscopicamente (Prancha 2-C), o Gnaisse Monlevade apresenta coloração cinza-claro, granulação muito fina a fina $(\leq 1 \mathrm{~mm})$ e bandamento muito persistente lateralmente porém extremamente variável quanto à espessura e espaçamento dos níveis máficos, o que dá à rocha um aspecto listado irregular, ressaltado ainda por intercalações centimétricas de níveis anfibolíticos. Apresenta espessuras de dezenas de metros (por exemplo, furo de sonda na área de Hematita: espessura mínima de $68 \mathrm{~m}$ ) e encontra-se freqüentemente alterado, resultando em rocha friável de coloração cinza-esverdeado.

Microscopicamente exibe grande variabilidade litológica, tendo sido encontrados biotita gnaisse, anfibólio-biotita gnaisse, granada-biotita gnaisse e sillimanita-granada-biotita gnaisse. Como características comuns a todas as litologias observadas destacam-se a quase ausência de microclínio e a textura granoblástica (grãos poligonais) desenvolvida pelos minerais plagioclásio, quartzo e microclínio.

A composição mineralógica dos níveis anfibolíticos também é variável: anfibolito, epídoto anfibolito e anfibólio-epídoto-biotita xisto. 


\section{VI.A.2.d. Xistos e quartzitos}

Foram observadas intercalações de espessuras variáveis (centimétricas a métricas) de xistos - (granada, cianita, sillimanita) quartzo-biotita xisto, quartzo-biotita xisto grafitoso e (cianita) quartzo-muscovita xisto, este último constituindo geralmente níveis dentro de unidades de muscovita quartzitos e quartzitos de várias dezenas de metros de espessura.

A ocorrência de quartzo-biotita xisto grafitoso foi constatada na área da Lavra de Esmeraldas de Ferros, como intercalações dentro do Gnaisse Monlevade. Em microscopia óptica observa-se a grafita como plaquetas acompanhando geralmente a clivagem da biotita ou ainda como inclusões em cristais de alexandrita.

$\mathrm{Na}$ área do garimpo de esmeraldas de Córrego das Pedras, às rochas metaultramáficas hospedeiras da mineralização associam-se também quartzo-biotita xisto e sillimanita-quartzo-biotita xisto. Em seção delgada observa-se uma rocha de estrutura bandada e textura granolepidoblástica equigranular, onde grãos ou agregados de quartzo estirados são contornados por niveis de biotita, que é substituída por cristais aciculares de sillimanita (fibrolita). Inclusões de fibrolita em quartzo também são comuns.

Veios constituídos de sillimanita fibrosa cortam ainda os níveis de quartzobiotita xisto.

Uma grande unidade de quartzitos e quartzo-muscovita xistos aflora nas imediações da Lavra de Hematita, tratando-se provavelmente da continuidade dos quartzitos, metaconglomerados e xistos do Grupo Caraça (Supergrupo Minas) mapeados por Schorscher (1992) (Fig.V.1).

O quartzo-muscovita xisto apresenta textura granolepidoblástica inequigranular orientada e estrutura bandada, com niveis de quartzo recristalizado alternando-se com níveis ricos em muscovita. Foram observados enriquecimentos locais de opacos, que concentram-se junto à muscovita.

Cianita também pode estar presente na forma de grãos alongados orientados segundo a foliação, intergranulares, ocupando o lugar da muscovita.

$\mathrm{Na}$ lavra de esmeraldas de Cantagalo, ao sul da cidade de Nova Era (Fig.l.1), predomina um granada-quartzo-biotita xisto de granulação fina, com porfiroblastos de granada de até $5 \mathrm{~mm}$. 
Em seção delgada observa-se que os porfiroblastos maiores de granada são contornados pela foliação e podem apresentar inclusões alongadas de quartzo, opacos ou biotita em orientação oblíqua à foliação externa.

A matriz dessa rocha compõe-se de biotita com forte pleocroísmo (amarelo-claro $\rightarrow$ castanho-alaranjado), quartzo em grãos alongados ou níveis de grãos recristalizados e grãos levemente alongados de plagioclásio.

\section{V.A.2.e. Gnaisse maciço com biotita}

A oeste da localidade de Itauninha (Fig.l.1), aflora um gnaisse de aspecto maciço, coloração cinza e granulação fina $(<1 \mathrm{~mm})$, com níveis de anfibolito e de gnaisse bandado formando intercalações naquele litotipo predominante.

Em seção delgada constata-se a estrutura homogênea e a textura levemente inequigranular orientada, com plaquetas finas de biotita orientadas e isoladas em meio a microclínio, quartzo e plagioclásio em grãos recristalizados.

Observa-se a substituição da biotita por muscovita que, em alguns casos, chega a ser quase completa, restando apenas pequenos e raros núcleos de biotita.

Além dos litotipos descritos acima, ocorrem ainda migmatitos e gnaisses migmatíticos pertencentes provavelmente à unidade de "terrenos graníticomigmatíticos arqueanos e proterozóicos policíclicos" descrita por Schorscher (1992).

Formações ferríferas são também de ocorrência bastante conhecida na região, constituindo corpos de minério de ferro de interesse econômico, tais como as áreas já exploradas de Piçarrão e Hematita.

\section{VI.B. Caracterização Geoquímica das Unidades Litológicas}

Análises químicas em rocha total foram realizadas em 30 amostras, sendo oito de Ortognaisse com Anfibólio e Biotita, oito de Ortognaisse com Biotita, cinco de paragnaisses e nove de rochas metaultramáficas.

Enquanto as amostras do Ortognaisse com Anfibólio e Biotita e dos paragnaisses provêm de pontos diversos da área de estudo, as amostras do 
Ortognaisse com Biotita concentram-se principalmente nas proximidades da Lavra de Hematita (Fig.I.1).

As rochas metaultramáficas são oriundas dos garimpos de esmeraldas de Córrego das Pedras e Limeira, onde trabalhos subterrâneos permitiram a amostragem dessas litologias menos resistentes ao intemperismo.

\section{VI.B.1. Rochas gnáissicas}

Os três grupos de rochas gnáissicas analisados (Tab.VI.1) apresentam composiçöes típicas de rochas graníticas (apesar da natureza paraderivada de um dos grupos de gnaisses), porém com teores em sílica superiores à média de $71,30 \%$ fornecida por Best (1982) para granitos.

Todas as amostras concentram-se no campo cálcico do diagrama de alcalinidade de Peacock (1931) (Fig.VI.1 - A), notando-se enriquecimento em sílica no Ortognaisse com Biotita em relação ao Ortognaisse com Anfibólio e Biotita.

No diagrama ANK $x$ ACNK de Maniar \& Piccoli (1989) (Fig.VI.1-B), esses dois grupos constituintes do Ortognaisse Açucena apresentam-se metaluminosos a peraluminosos, enquanto os paragnaisses demonstram-se peraluminosos.

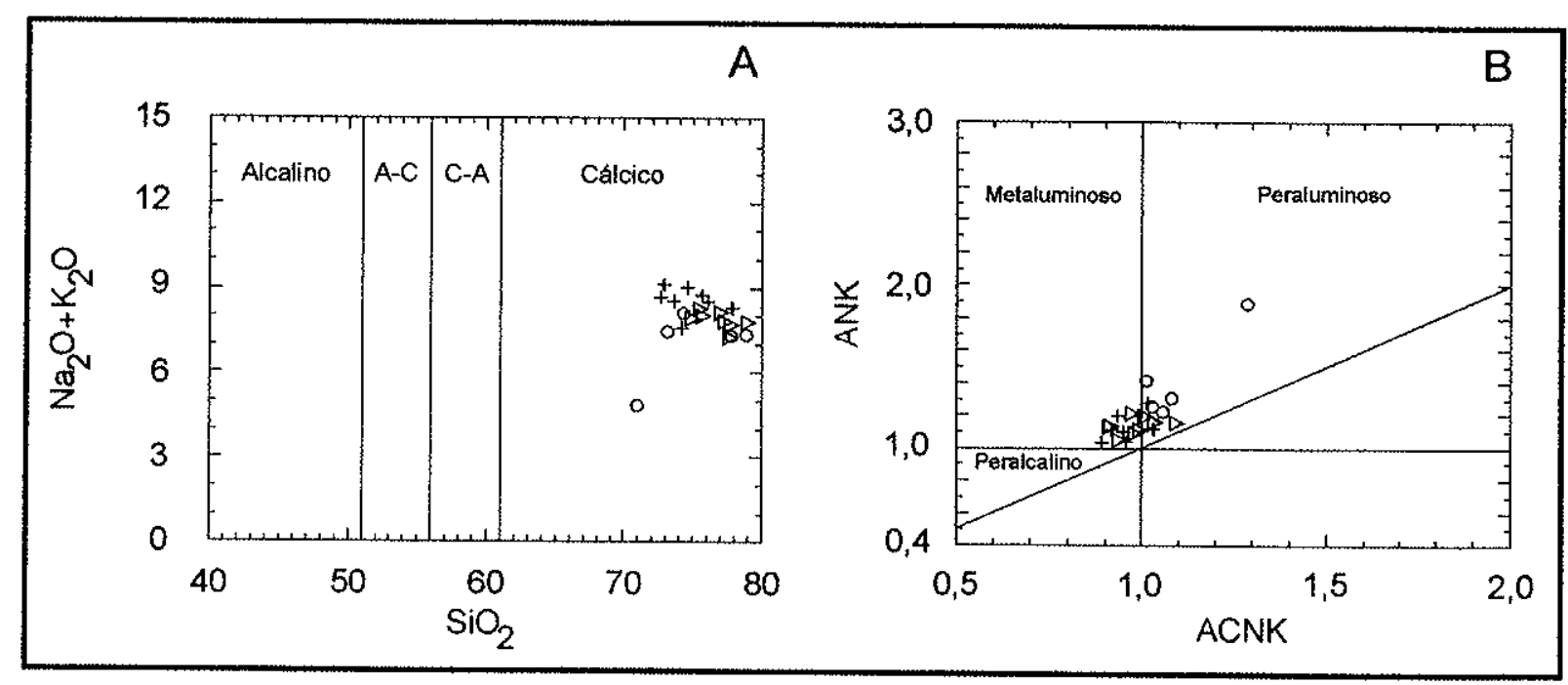

Fig.VI.1: Distribuição das rochas gnáissicas no diagrama de alcalinidade de Peacock (1931) (A) e no diagrama ANKXACNK de Maniar \& Piccoli (1989) (B). (+): Ortognaisse com Anfibólio e Biotita; $(D)$ : Ortognaisse com Biotita; (o): paragnaisse. 


\begin{tabular}{|c|c|c|c|c|c|c|c|c|c|c|c|c|c|c|c|c|c|c|c|c|c|c|}
\hline & $\begin{array}{c}\text { limite } \\
\text { detecça } \\
0\end{array}$ & $\begin{array}{l}\text { S-10 } \\
(+)\end{array}$ & $\begin{array}{c}S-27 \\
(+)\end{array}$ & $\begin{array}{c}S-35 \\
(+)\end{array}$ & $\begin{array}{c}\text { S-36 } \\
(+)\end{array}$ & $\begin{array}{l}S-45 \\
(+)\end{array}$ & $\begin{array}{c}\text { S-102 } \\
(+)\end{array}$ & $\begin{array}{c}\text { S-103 } \\
(+)\end{array}$ & $\begin{array}{c}\text { S-104 } \\
(+)\end{array}$ & $\begin{array}{l}S-1 \\
D)\end{array}$ & $\begin{array}{l}S-3 \\
D)\end{array}$ & $\begin{array}{c}S-15 \\
D)\end{array}$ & $\begin{array}{l}S-21 \\
(D)\end{array}$ & $\begin{array}{l}S-40 \\
D)\end{array}$ & $\begin{array}{l}S-48 \\
(D)\end{array}$ & $\begin{array}{l}S-65 \\
D)\end{array}$ & $\begin{array}{l}S-85 \\
D)\end{array}$ & $\begin{array}{c}S-34 \\
(0)\end{array}$ & $\begin{array}{c}s-60 a \\
(0)\end{array}$ & $\begin{array}{c}5-63 \\
\text { (0) }\end{array}$ & $\begin{array}{l}\text { S-95a } \\
\text { (o) }\end{array}$ & $\begin{array}{c}\text { S-108 } \\
\text { (o) }\end{array}$ \\
\hline $\mathrm{SiO}_{2}$ & 0.01 & 75,40 & 72,30 & 74,50 & 73,02 & 73,90 & 75,70 & 77,50 & 74,40 & 77,50 & 79,20 & 78,00 & 77,97 & 75,67 & 75,10 & 77,20 & 75,80 & 77,80 & 72,80 & 74,30 & 70,90 & 78,70 \\
\hline $\mathrm{TiO}_{2}$ & 0.001 & 0,19 & 0,27 & 0,30 & 0,22 & 0,20 & 0,19 & 0,19 & 0,25 & 0,09 & 0,04 & 0,11 & 0,09 & 0,11 & 0,19 & 0,21 & 0,16 & 0,11 & 0,28 & 0,15 & 0,21 & 0,07 \\
\hline $\mathrm{Al}_{2} \mathrm{O}_{3}$ & 0.02 & 12,48 & 13,24 & 12,47 & 13,71 & 13,10 & 11,47 & 11,58 & 12,82 & 11,01 & 11,66 & 11,10 & 11,45 & 12,24 & 12,28 & 11,58 & 11,50 & 12,32 & 14,69 & 13,72 & $\{4,37$ & 12,03 \\
\hline $\mathrm{Fe}_{2} \mathrm{O}_{3}$ & 0.01 & 2,40 & 2,90 & 2,84 & 2,70 & 2,05 & 2,66 & 2,21 & 3,03 & 1,65 & 1,21 & 1,19 & 1,53 & 1,66 & 2,16 & 2,34 & 2,51 & 1,33 & 2,02 & 1,05 & 4,29 & 1,27 \\
\hline $\mathrm{MnO}$ & 0.0006 & 0,04 & 0,04 & 0,04 & 0,04 & 0,03 & 0,04 & 0,03 & 0,05 & 0,02 & 0,02 & 0,02 & 0,01 & 0,01 & 0,03 & 0,03 & 0,03 & 0,02 & 0,03 & 0,02 & 0,75 & 0,01 \\
\hline $\mathrm{MgO}$ & 0.01 & nd & 0,04 & 0,07 & 0,02 & 0,03 & 0,01 & nd & nd & nd & nd & 0,43 & nd & 0,05 & 0,08 & 0,01 & nd & 0,13 & 0,55 & 0,30 & 1,64 & 0,01 \\
\hline $\mathrm{CaO}$ & 0.01 & 0,94 & 1,13 & 1,15 & 0,84 & 0,80 & 0,85 & 0,70 & 0,96 & 0,81 & 0,64 & 0,33 & 0,69 & 0,89 & 0,88 & 0,73 & 0,76 & 1,06 & 2,29 & 1,01 & 2,06 & 1,06 \\
\hline $\mathrm{Na}_{2} \mathrm{O}$ & 0.02 & 3,86 & 3,83 & 2,99 & 4,20 & 3,72 & 3,34 & 3,63 & 3,79 & 3,25 & 3,81 & 2,06 & 3,54 & 3,59 & 3,06 & 3,14 & 3,57 & 2,83 & 3,81 & 4,30 & 4,24 & 3,22 \\
\hline $\mathrm{K}_{2} \mathrm{O}$ & 0.01 & 4,81 & 4,94 & 4,83 & 4,93 & 4,87 & 5,11 & 4,55 & 5,29 & 4,56 & 3,95 & 5,69 & 3,76 & 4,53 & 4,96 & 4,96 & 4,56 & 4,50 & 3,77 & 3,81 & 0,61 & 4,17 \\
\hline $\mathrm{P}_{2} \mathrm{O}_{5}$ & 0.005 & nd & 0,01 & nd & 0,02 & 0,02 & nd & nd & nd & nd & nd & 0,02 & 0,01 & 0,01 & 0,02 & nd & nd & nd & nd & 0,04 & nd & nd \\
\hline LOI & 0.0 & 0,2 & 0,6 & 0,2 & 0,2 & 0,2 & 0,1 & 0,1 & 0,1 & 0,4 & 0,3 & 0,3 & 0,7 & 0,5 & 0,3 & 0,1 & 0,2 & 0,6 & 0,3 & 0,3 & 0,5 & 0,2 \\
\hline Total & & 100,5 & 99,3 & 99,6 & 99,8 & 99,0 & 99,6 & 100,6 & 100,9 & 99,2 & 100,9 & 99,2 & 99,8 & 99,3 & 99,3 & 100,5 & 99,2 & 100,7 & 100,7 & 99,1 & 100,5 & 100,9 \\
\hline $\mathrm{Ba}$ & 20 & 809 & 1099 & 1320 & 722 & 612 & 386 & 435 & 827 & 37 & 61 & 199 & 9 & 180 & 333 & 663 & 434 & 108 & 579 & 741 & 92 & 153 \\
\hline $\mathrm{Rb}$ & 4 & 207 & 160 & 154 & 209 & 180 & 216 & 201 & 197 & 354 & 483 & 308 & 338 & 371 & 290 & 201 & 292 & 244 & 116 & 188 & 17 & 284 \\
\hline $\mathrm{Sr}$ & 4 & 45 & 87 & 124 & 56 & 57 & 28 & 30 & 50 & 7 & 9 & 36 & 15 & 21 & 55 & 37 & 24 & 25 & 164 & 147 & 116 & 29 \\
\hline Cs & 30 & 0 & 0 & 0 & 0 & 0 & 0 & 0 & 0 & 0 & 6 & 0 & 0 & 0 & 0 & 0 & 5 & 0 & 17 & 0 & 0 & 25 \\
\hline Ga & 4 & 24 & 19 & 20 & 23 & 21 & 22 & 24 & 22 & 33 & 32 & 17 & 24 & 28 & 17 & 24 & 25 & 27 & 20 & 13 & 26 & 31 \\
\hline $\mathrm{Ta}$ & 8 & 1 & 0 & 3 & 0 & 0 & 0 & 0 & 0 & 10 & 1 & 0 & 1 & 0 & 0 & 0 & 0 & 0 & 6 & 0 & 0 & 4 \\
\hline No & 4 & 60 & 44 & 20 & 49 & 37 & 49 & 38 & 52 & 197 & 60 & 12 & 167 & 80 & 28 & 29 & 71 & 55 & 8 & 3,0 & 37 & 116 \\
\hline $\mathrm{Zr}$ & 4 & 414 & 579 & 493 & 516 & 658 & 528 & 460 & 614 & 269 & 132 & 132 & 266 & 288 & 382 & 384 & 341 & 342 & 198 & 119 & 591 & 204 \\
\hline$Y$ & 4 & 89 & 110 & 95 & 100 & 59 & 117 & 91 & 87 & 354 & 211 & 70 & 301 & 139 & 174 & 91 & 117 & 516 & 10 & 33 & 147 & 113 \\
\hline Th & 4 & 30 & 21 & 14 & 41 & 19 & 33 & 33 & 18 & 44 & 39 & 38 & 32 & 44 & 44 & 34 & 40 & 49 & 39 & 22 & 10 & 37 \\
\hline$U$ & 6 & 11 & 0 & 2 & 0 & 0 & 0 & 0 & 3 & 20 & 11 & 0 & 16 & 5 & 10 & 2 & 3 & 2 & 12 & 0 & 0 & 10 \\
\hline $\mathrm{Cr}$ & 6 & 14 & 0 & 18 & 0 & 1 & 25 & 20 & 8 & 17 & 15 & 0 & 4 & 0 & 0 & 20 & 24 & 15 & 26 & 6 & 20 & 22 \\
\hline $\mathrm{Ni}$ & 6 & 4 & 5 & 8 & 2 & 8 & 3 & 0 & 99 & 9 & 10 & 13 & 13 & 6 & 12 & 5 & 6 & 12 & 3 & 11 & 2 & 8 \\
\hline $\mathrm{Cu}$ & 8 & 8 & 0 & 3 & 0 & 0 & 6 & 6 & 0 & 0 & 5 & 0 & 0 & 0 & 0 & 0 & 4 & 3 & 5 & 2 & 103 & 6 \\
\hline $\mathrm{Pb}$ & 10 & 42 & 44 & 40 & 47 & 48 & 24 & 28 & 36 & 59 & 56 & 47 & 69 & 43 & 55 & 40 & 31 & 43 & 32 & 43 & 72 & 71 \\
\hline $\mathrm{Zn}$ & 6 & 133 & 98 & 73 & 103 & 67 & 127 & 93 & 127 & 101 & 99 & 6 & 81 & 29 & 46 & 92 & 97 & 63 & 27 & 45 & 4798 & 78 \\
\hline$F$ & 0.4 & 0 & 0 & 0 & 0 & 0 & 0 & 0 & 0 & 0 & 0 & 0 & 0 & 0 & 0 & 0 & 0 & 0 & 0 & 0 & 0 & 0 \\
\hline $\mathrm{Be}$ & 3 & 11 & 7 & 11 & 11 & 9 & 12 & 9 & 8 & 8 & 5 & 8 & 11 & 14 & 14 & 9 & 12 & 13 & 9 & 10 & 9 & 14 \\
\hline As & 20 & 0 & 3 & 6 & 12 & 0 & 7 & 1 & 0 & 1 & 0 & 9 & 0 & 16 & 10 & 0 & 6 & 6 & 0 & 5 & 18 & 0 \\
\hline $\mathrm{La}$ & 30 & 211 & 217 & 154 & 255 & 128 & 144 & 184 & 109 & 146 & 93 & 61 & 110 & 113 & 329 & 99 & 163 & 134 & 67 & 34 & 75 & 0 \\
\hline $\mathrm{Ce}$ & 40 & 346 & 369 & 178 & 362 & 209 & 298 & 343 & 233 & 230 & 177 & 139 & 167 & 150 & 326 & 237 & 254 & 209 & 100 & 39 & 149 & 0 \\
\hline $\mathrm{Nd}$ & 30 & 125 & 139 & 132 & 152 & 62 & 104 & 139 & 99 & 134 & 74 & 53 & 97 & 87 & 0 & 152 & 95 & 85 & 17 & 0 & 108 & 0 \\
\hline
\end{tabular}

Tab.VI.1: Análises químicas por fluorescência de raios $\mathrm{X}$ e absorção atômica $(\mathrm{Be})$ das rochas gnáissicas. (+): Ortognaisse com Anfibólio e Biotita; ( $D$ ): Ortognaisse com Biotita; (o): paragnaisses. LOI: perda ao fogo; $\mathrm{SiO}_{2}-$ Total: \% peso; $\mathrm{Ba}-\mathrm{Nd}$ : ppm. 
A natureza peraluminosa reflete-se na presença de coríndon normativo em todas as amostras de paragnaisses, enquanto a tendência metaluminosa a peraluminosa dos dois grupos de ortognaisses é indicada pela ausência ou valor muito baixo de $\mathrm{C}$ normativo.

Nos diagramas de correlação $\mathrm{SiO}_{2} x$ demais óxidos (Fig.VI.2), $\mathrm{TiO}_{2}, \mathrm{MnO}$, $\mathrm{CaO}$ e $\mathrm{Al}_{2} \mathrm{O}_{3}$ permitem uma boa separação entre o Ortognaisse com Anfibólio e Biotita e o Ortognaisse com Biotita, enquanto $\mathrm{MgO}, \mathrm{K}_{2} \mathrm{O}$ e $\mathrm{Na}_{2} \mathrm{O}$ não apresentam distinção entre os dois grupos, sobressaindo-se apenas o enriquecimento em sílica do Ortognaisse com Biotita.

Já o diagrama $\mathrm{K} / \mathrm{Rb} \times \mathrm{SiO}_{2}$ (Fig.VI.2) revela enriquecimento em elementos incompativeis com o aumento de $\mathrm{SiO}_{2}$, ou seja, na direção do Ortognaisse com Biotita. Na classificação de El Bouseily \& El Sokkary (1975) (Fig.VI.3), o Ortognaisse com Biotita também figura como mais diferenciado em relação ao Ortognaisse com Anfibólio e Biotita, ou seja, com tendência de enriquecimento em Rb.

Os paragnaisses demonstram comportamento bastante aleatório, provavelmente refletindo grande diversidade de protólitos.

Quanto aos teores em Be, todas as rochas gnáissicas apresentaram valores acima da média de 4,5ppm obtida por Wuensch \& Hörmann (1969) para biotita granitos (Fig.VI.4), porém situando-se ao redor da média de 10ppm para muscovita granitos resultantes de processos de greisenização. No entanto, minerais característicos desse processo, tais como topázio, wolframita, molibdenita e muscovita não foram encontrados, destacando-se apenas a presença de fluorita no Ortognaisse com Biotita.

\section{VI.B.2. Rochas metaultramáficas}

Apesar das rochas metaultramáficas analisadas (Tab.VI.2) hospedarem mineralizações de esmeraldas e terem sofrido portanto modificações químicas por processos metassomáticos, sua natureza originalmente ultramáfica ainda pode ser reconhecida em diagramas de classificação como o da figura VI.5-A. 


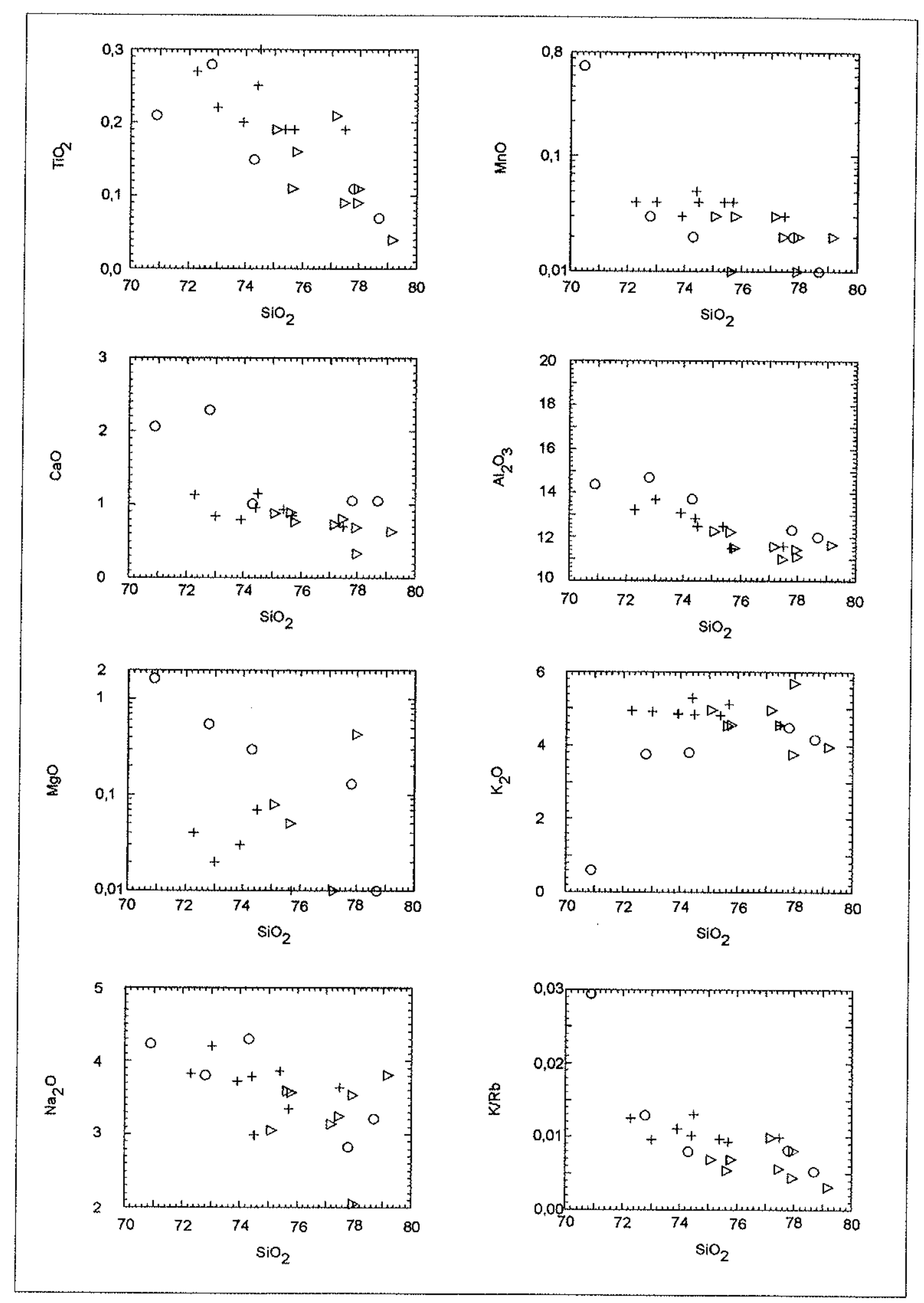

Fig.V1.2: Diagramas $\mathrm{SiO}_{2} \times$ demais óxidos para as rochas gnáissicas. (+): Ortognaisse com Anfibólio e Biotita; $(\triangleright)$ : Ortognaisse com Biotita; (o): paragnaisse. 


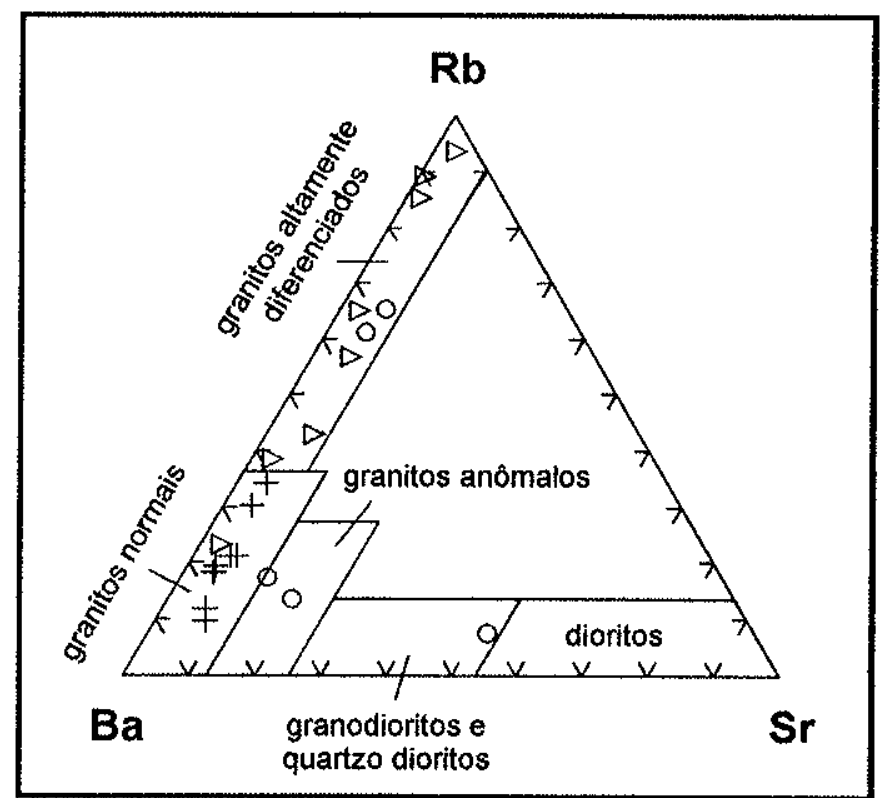

Fig.VI.3: Diagrama RbxSrxBa de El Bouseily \& El Sokkary (1975) para as rochas gnáissicas. (+): Ortognaisse com Anfibólio e Biotita; $(D)$ : Ortognaisse com Biotita; (o): paragnaisse.

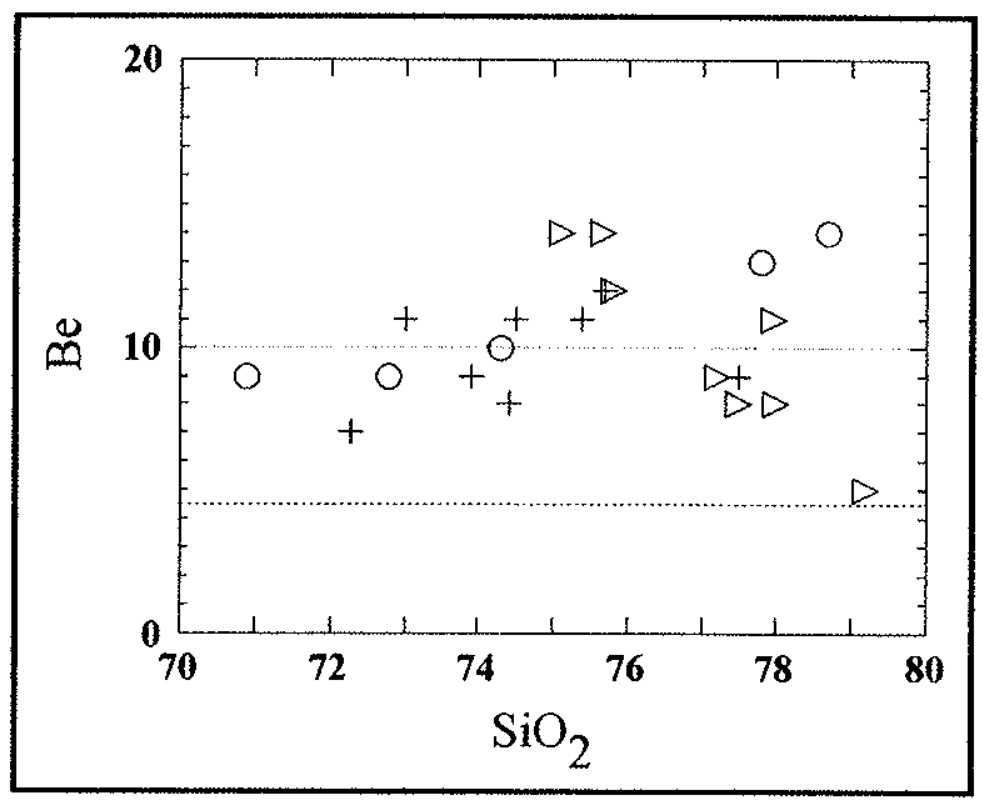

Fig.VI.4: Teores de Be (ppm) em função do teor em silica (\% em peso) para as rochas gnáissicas. $(+)$ : Ortognaisse com Anfibólio e Biotita; $(\gg)$ : Ortognaisse com Biotita; (o): paragnaisse; ----- : teor médio para biotita granitos, ….... : teor médio para muscovita granitos (Wuensch \& Hörmann 1969). 
No entanto, uma classificação mais detalhada dentro do grupo de rochas ultramáficas já não é possível (Fig.VI.5-B,C,D), sugerindo que mesmo elementos considerados imóveis, como $\mathrm{Ni}, \mathrm{Cr}$ e Ti, tiveram suas concentrações modificadas ao longo dos processos de metamorfismo e metassomatismo a que foram submetidas essas rochas.

A atuação dos processos metassomáticos fica mais evidente na análise de figura VI.6, onde o comportamento de determinados elementos traço é correlacionado ao enriquecimento em $\mathrm{K}_{2} \mathrm{O}$ na passagem de tremolititos e xistos para flogopititos.

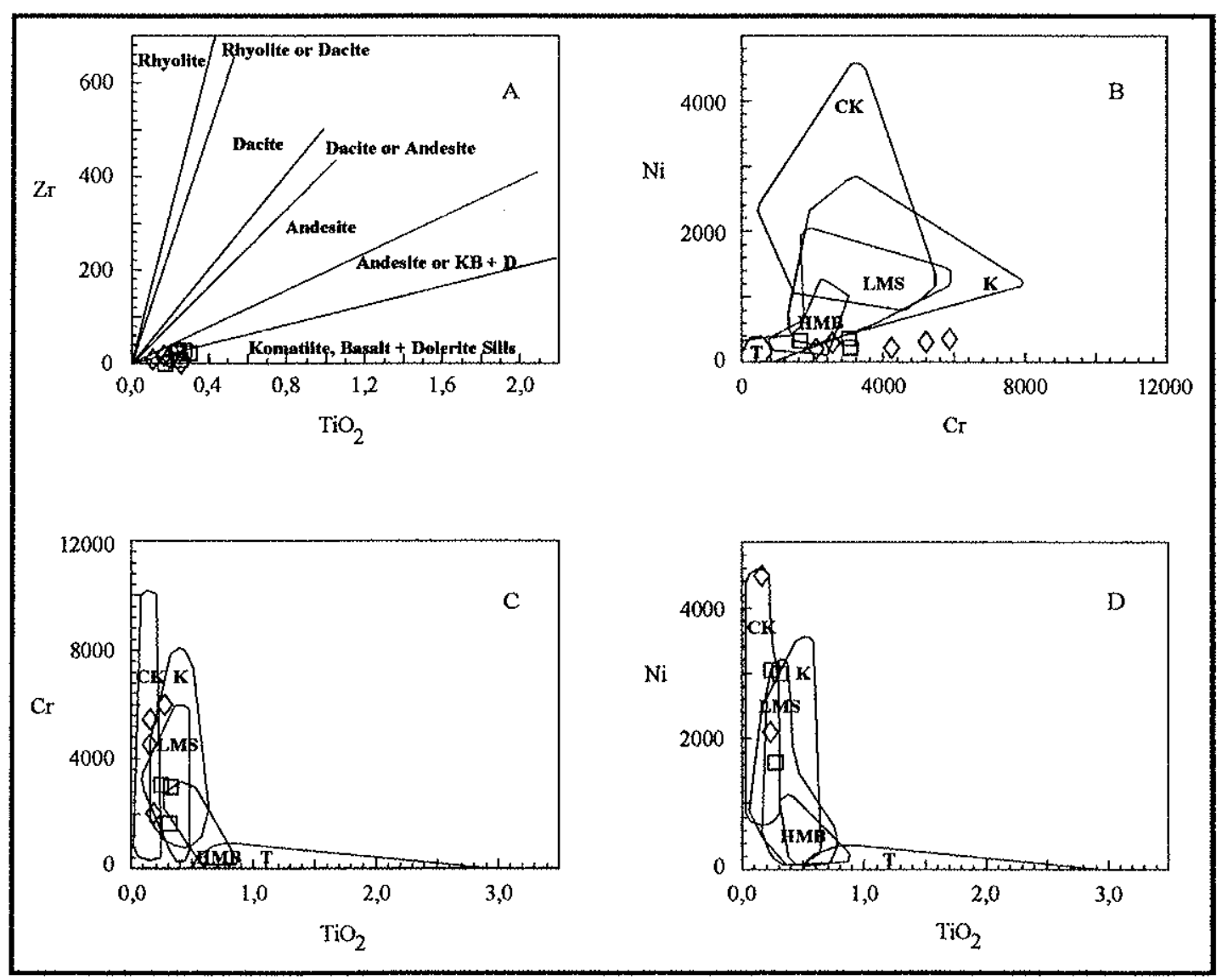

Fig.VI.5: Posicionamento das rochas metaultramáficas em diagramas classificatórios de Hallberg (1985 apud Programa Minpet). ([)): tremolititos e xistos; ( $)$ ): flogopititos. $\mathrm{T}$ : basaltos toleíticos; HMB: high-Mg basaltos; LMS: low-Mg silis; $\mathrm{K}$ : komatiitos; CK: komatiitos cumuláticos. 


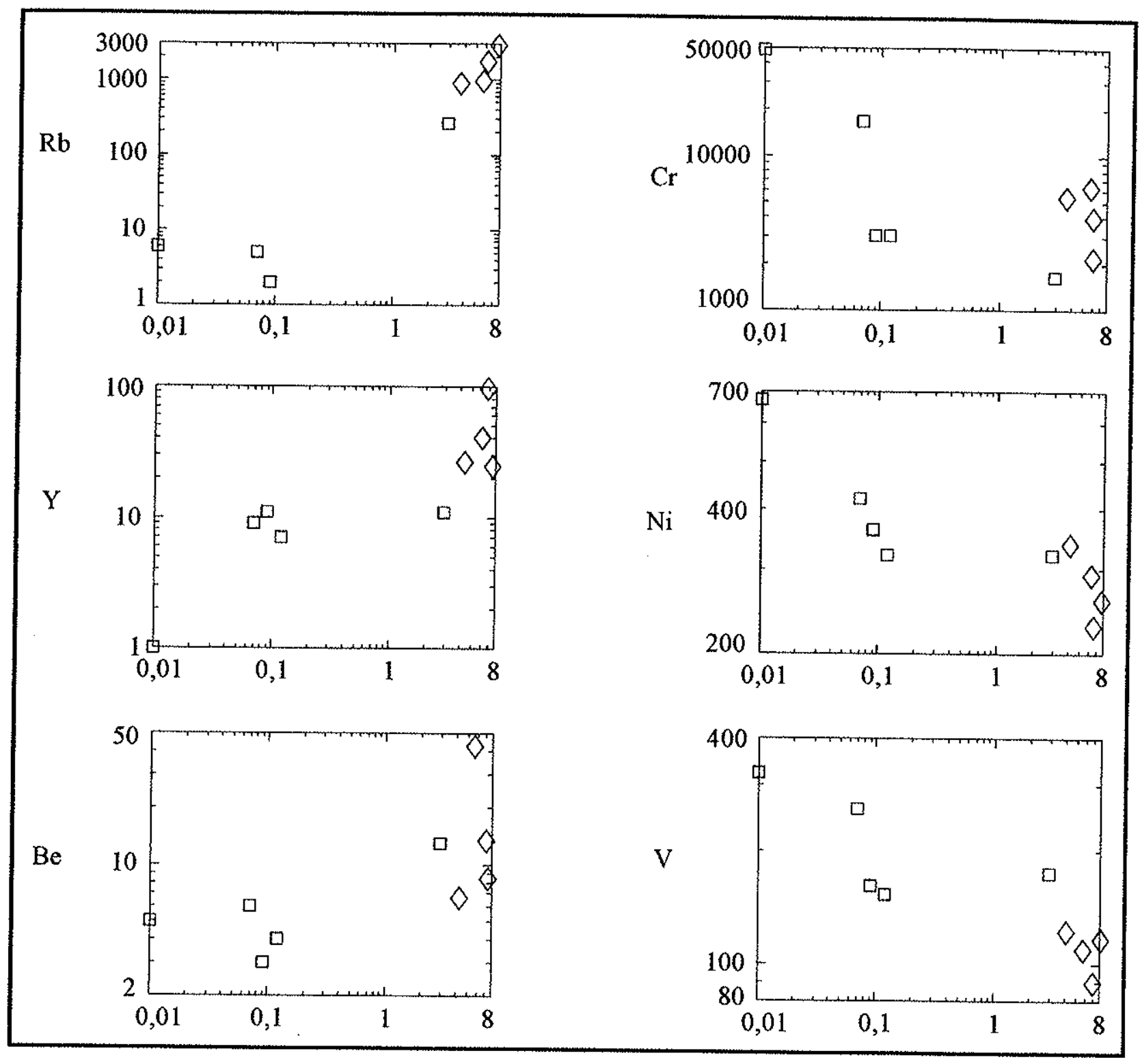

Fig.VI.6: Comportamento dos elementos traço em função do teor em $\mathrm{K}_{2} \mathrm{O}$ nas rochas metaultramáficas. $(\square)$ : tremolititos e xistos; $(0)$ : flogopititos.

$\mathrm{O}$ aumento no teor de $\mathrm{K}_{2} \mathrm{O}$ é acompanhado por elevações nos teores em elementos incompativeis, como $\mathrm{Rb}, \mathrm{Y}$ e $\mathrm{Be}$, enquanto $\mathrm{Ni}, \mathrm{Cr}$ e $\mathrm{V}$ apresentam correlação negativa com $\mathrm{K}_{2} \mathrm{O}$.

Os teores em Be (Tab.VI.2) para todas as metaultramáficas analisadas são ainda muito superiores à média de $0,25 \mathrm{ppm}$ apresentada por Wuensch \& Hörmann (1969) para rochas ígneas comuns. 


\begin{tabular}{|c|c|c|c|c|c|c|c|c|c|c|}
\hline & $\begin{array}{c}\text { limite } \\
\text { deteccăo }\end{array}$ & $\begin{array}{c}\text { CP-4a } \\
\text { (D) }\end{array}$ & $\begin{array}{c}C P-4 b \\
\text { (IJ) }\end{array}$ & $\begin{array}{c}\text { S-75 } \\
(\text { ㅁ) }\end{array}$ & $\begin{array}{c}\text { S.83a } \\
\text { (D) }\end{array}$ & $\begin{array}{c}\text { S-106 } \\
\text { (C) }\end{array}$ & $\begin{array}{c}\text { CP-5 } \\
(4)\end{array}$ & $\begin{array}{c}\text { CP.5a } \\
(4)\end{array}$ & $\begin{array}{c}S-51 \\
(\bullet)\end{array}$ & $\begin{array}{l}\text { S-53 } \\
(4)\end{array}$ \\
\hline $\mathrm{SiO}_{2}$ & 0.01 & 50.50 & 46.50 & 34.40 & 50.50 & 48.80 & 47.80 & 47.70 & 49.10 & 49.70 \\
\hline $\mathrm{TiO}_{2}$ & 0.001 & 0.24 & 0.30 & 0.17 & 0.25 & 0.27 & 0.26 & 0.18 & 0.22 & 0.15 \\
\hline $\mathrm{Al}_{2} \mathrm{O}_{3}$ & 0.02 & 8.17 & 10.74 & 13.07 & 6.80 & 8.92 & 8.86 & 10.83 & 10.41 & 6.98 \\
\hline $\mathrm{FeO}$ & 0.01 & 8.82 & 9.67 & 7.79 & 8.51 & 9.41 & 8.31 & $\$ 1.99$ & 8.51 & 6.16 \\
\hline MnO & 0.0006 & 0.18 & 0.17 & 0.11 & 0.16 & 0.33 & 0.18 & 0.17 & 0.20 & 0.13 \\
\hline $\mathrm{MgO}$ & 0.01 & 20.40 & 21.35 & 28.65 & 20.50 & 14.57 & 19.44 & 14.90 & 18.03 & 22.30 \\
\hline $\mathrm{CaO}$ & 0.01 & 7.45 & 5.11 & 0.88 & 6.08 & 9.68 & 2.87 & 0.25 & 0.18 & 4.90 \\
\hline $\mathrm{Na}_{2} \mathrm{O}$ & 0.02 & 0.98 & 0.75 & nd & 0.43 & 0.99 & 0.42 & 0.24 & 0.43 & 0.81 \\
\hline $\mathrm{K}_{2} \mathrm{O}$ & 0.01 & 0.12 & 0.09 & 0.01 & 0.07 & 2.94 & 6.55 & 7.60 & 7.89 & 3.89 \\
\hline $\mathrm{P}_{2} \mathrm{O}_{5}$ & 0.005 & nd & nd & 0.01 & nd & nd & nd & nd & nd & nd \\
\hline LOI & 0.0 & 1.4 & 3.4 & 6.4 & 2.6 & 1.8 & 0.5 & 0.7 & 0.6 & 1.2 \\
\hline Total & 0.0 & 98.7 & 98.5 & 98.8 & 98.8 & 98.2 & 99.5 & 98.0 & 98.9 & 98.6 \\
\hline$F$ & 0.4 & nd & nd & 0.1 & nd & 0.3 & 3.1 & 2.5 & 2.7 & 1.4 \\
\hline $\mathrm{Ba}$ & 20 & nd & 23 & nd & 17 & 255 & 116 & 225 & 219 & 65 \\
\hline $\mathrm{Rb}$ & 4 & nd & 2 & 6 & 5 & 265 & 1269 & 1847 & 2860 & 1066 \\
\hline $\mathrm{Sr}$ & 4 & 10 & 7 & nd & 4 & 68 & 3 & 5 & 7 & 3 \\
\hline Cs & 30 & nd & 23 & nd & nd & nd & 15 & 1 & nd & 7 \\
\hline $\mathrm{Ga}$ & 4 & 10 & 8 & 14 & 7 & 17 & 16 & 44 & 21 & 2 \\
\hline $\mathrm{Ta}$ & 8 & 5 & nd & nd & nd & nd & 5 & nd & nd & 1 \\
\hline $\mathrm{Nb}$ & 4 & 4 & 3 & 3 & nd & 5 & 11 & 62 & 46 & 5 \\
\hline $\mathrm{Zr}$ & 4 & 24 & 23 & 1 & 8 & 20 & 8 & 17 & 14 & 10 \\
\hline$Y$ & 4 & 7 & 11 & 1 & 9 & 11 & 37 & 27 & 100 & 25 \\
\hline Th & 4 & 4 & nd & nd & 4 & 5 & 2 & 3 & nd & 3 \\
\hline $\mathrm{U}$ & 6 & nd & nd & 9 & 1 & 1 & 8 & 7 & 11 & 8 \\
\hline $\mathrm{Cr}$ & 6 & 3045 & 3022 & 48727 & 16833 & 1635 & 5895 & 4503 & 2053 & 5551 \\
\hline $\mathrm{Ni}$ & 6 & 320 & 362 & 671 & 419 & 320 & 291 & 231 & 261 & 332 \\
\hline V & 6 & 154 & 162 & 323 & 260 & 175 & 116 & 90 & $\$ 18$ & 123 \\
\hline $\mathrm{Cu}$ & 8 & nd & nd & 13 & 4 & nd & nd & nd & nd & nd \\
\hline $\mathrm{Pb}$ & 10 & 3 & 2 & 9 & 8 & 11 & nd & nd & nd & nd \\
\hline $\mathrm{Zn}$ & 6 & 72 & 89 & 649 & 465 & 394 & 628 & 752 & 1029 & 172 \\
\hline Sn & 30 & 4 & 3 & 14 & 18 & 44 & 28 & 67 & 12 & 15 \\
\hline $\mathrm{Be}$ & 3 & 4 & 3 & 5 & 6 & 13 & 45 & 13 & 9 & 7 \\
\hline As & 20 & nd & 8 & nd & 8 & 22 & 7 & 1 & 14 & 2 \\
\hline La & 30 & nd & nd & nd & 4 & nd & nd & nd & nd & nd \\
\hline $\mathrm{Ce}$ & 40 & nd & nd & nd & nd & 35 & nd & nd & 8 & 2 \\
\hline $\mathrm{Nd}$ & 30 & 6 & nd & nd & nd & 18 & nd & nd & nd & 1 \\
\hline
\end{tabular}

Tab.VI.2: Análises químicas por fluorescência de raios $\mathrm{X}$ e absorção atômica (Be) das rochas metaultramáficas. $(\square)$ : tremolititos e xistos; $(0)$ : flogopititos. LOI: perda ao fogo; $\mathrm{SiO}_{2}$ - Total: \% peso; $\mathrm{Ba}-\mathrm{Nd}$ : ppm. 
VI.C. Química Mineral

Com o emprego da microssonda eletrônica, as composições químicas de anfibólios, biotitas, flogopitas e cromitas foram determinadas objetivando a melhor caracterização das unidades litológicas descritas anteriormente.

\section{V.C.1. Anfibólios}

Foram analisados anfibólios de duas amostras do Ortognaisse com Anfibólio e Biotita, uma amostra de anfibolito e uma de flogopitito, cujos resultados encontram-se na tabela VI.3.

$O$ anfibólio azul-esverdeado, observado como restos de grãos em flogopitito mineralizado em esmeraldas da ocorrência de Córrego das Pedras, destaca-se dos demais pelos seus teores mais elevados em $\mathrm{Cr}_{2} \mathrm{O}_{3}(0,45$ a 1,25\%) e $F(1,02$ a $1,57 \%)$.

No diagrama de classificação entre os quatro grupos principais, todos os dados posicionaram-se dentro do campo dos anfibólios cálcicos (Fig. V.7-A,C).

$O$ anfibólio do flogopitito distribui-se entre actinolita, hornblenda actinolítica e Mg-hornblenda, enquanto o anfibólio constituinte do anfibolito encontrado nas proximidades da Lavra de Hematita concentra-se no campo da hornblenda tschermackítica (Fig.VI.7-B).

Resultado interessante é apresentado pelos anfibólios das amostras S-12 e S-10: embora sejam provenientes do mesmo litotipo - Ortognaisse com Anfibólio e Biotita - e situem-se no campo da hornblenda hastingsítica, observa-se que anfibólios da amostra mais orientada (S-10) apresentam tendência em direção ao campo da hastingsita (Fig.Vl.7-D), ou seja, em direção a um leve aumento na substituição TSi $\rightarrow$ TAl. Analisando-se a tabela VI.3, constata-se ainda a substiuição simultânea $\mathrm{C}(\mathrm{Mg}, \mathrm{Fe}) \mathrm{TSi} \rightarrow \mathrm{CAlTAl}$. 


\begin{tabular}{|c|c|c|c|c|c|c|c|c|c|c|c|c|c|c|c|c|c|c|c|c|c|c|}
\hline amostra & CP-5 & CP-5 & CP-5 & CP-5 & $C P-5$ & $\mathrm{CP}-5$ & $\mathrm{HM}-10$ & $\mathrm{HM}-10$ & $H M-10$ & HM-10 & HM-10 & $\mathrm{S}-10$ & S-10 & $\mathrm{S}-10$ & S-10 & $\mathrm{S}-10$ & S-12 & $S-12$ & S-12 & S-12 & S-12 & S-12 \\
\hline ponto & 13 & 14 & 15 & 16 & 17 & 18 & 6 & 7 & 8 & 10 & 11 & 4 & 6 & 10 & 11 & 12 & 4 & 5 & 6 & 7 & 8 & 9 \\
\hline $\mathrm{SiO}_{2}$ & 50.50 & 51.33 & 51.74 & 52.27 & 53.58 & 49.91 & 42.28 & 42.82 & 42.28 & 42.74 & 42.64 & 38.48 & 38.37 & 38.43 & 37.68 & 38.07 & 39.42 & 38.90 & 39.22 & 39.60 & 39.40 & 39.16 \\
\hline $\mathrm{TiO} 2$ & 0.06 & nd & 0.09 & 0.03 & 0.09 & nd & 0.83 & 0.97 & 0.80 & 0.89 & 0.78 & 1.01 & 1.07 & 1.08 & 1.05 & 1.05 & 1.37 & 1.39 & 1.27 & 1.63 & 1.49 & 1.45 \\
\hline $\mathrm{Al} 2 \mathrm{O} 3$ & 4.40 & 3.88 & 4.04 & 2.69 & 2.11 & 4.28 & 12.79 & 12.07 & 12.20 & 12.18 & 11.92 & 9.68 & 10.38 & 9.42 & 9.57 & 9.96 & 9.17 & 8.95 & 9.10 & 9.38 & 9.11 & 8.96 \\
\hline $\mathrm{FeO}$ & 8.69 & 8.36 & 8.87 & 9.15 & 9.14 & 9.31 & 18.00 & 17.68 & 17.64 & 18.12 & 18.72 & 32.11 & 32.72 & 31.49 & 30.67 & 31.63 & 32.17 & 32.15 & 32.36 & 32.15 & 31.45 & 31.12 \\
\hline $\mathrm{Cr} 2 \mathrm{O} 3$ & 1.21 & 1.00 & 0.98 & 0.63 & 0.45 & 1.16 & 0.05 & nd & 0.03 & 0.03 & nd & 0.08 & 0.01 & 0.01 & 0.05 & 0.06 & 0.08 & nd & 0.16 & 0.10 & nd & 0.07 \\
\hline $\mathrm{MmO}$ & 0.28 & 0.29 & 0.27 & 0.34 & 0.37 & 0.33 & 0.21 & 0.18 & 0.25 & 0.27 & 0.27 & 0.78 & 0.81 & 0.86 & 0.74 & 0.77 & 0.64 & 0.60 & 0.59 & 0.60 & 0.56 & 0.55 \\
\hline $\mathrm{MgO}$ & 17.63 & 17.27 & 17.22 & 18.30 & 18.26 & 17.09 & 8.42 & 8.74 & 8.89 & 8.56 & 9.02 & 0.25 & 0.31 & 0.26 & 0.19 & 0.12 & 0.41 & 0.36 & 0.42 & 0.44 & 0.37 & 0.47 \\
\hline $\mathrm{CaO}$ & 12.28 & 12.47 & 12.26 & 12.64 & 12.43 & 12.41 & 11.85 & 11.79 & 11.60 & 11.75 & 11.83 & 10.43 & 10.52 & 10.28 & 10.44 & 10.42 & 10.21 & 10.33 & 10.62 & 10.24 & 10.38 & 10.53 \\
\hline $\mathrm{Na} 2 \mathrm{O}$ & 1.11 & 1.05 & 1.05 & 1.03 & 0.60 & 1.10 & 1.52 & 1.36 & 1.37 & 1.34 & 1.40 & 1.74 & 1.86 & 1.80 & 1.87 & 1.55 & 1.92 & 1.93 & 1.77 & 1.99 & 1.82 & 1.85 \\
\hline $\mathrm{K} 2 \mathrm{O}$ & 0.55 & 0.43 & 0.47 & 0.26 & 0.18 & 0.55 & 0.64 & 0.57 & 0.60 & 0.53 & 0.59 & 1.79 & 1.77 & 1.70 & 1.77 & 1.79 & 1.58 & 1.63 & 1.69 & 1.65 & 1.66 & 1.63 \\
\hline $\mathrm{F}$ & 1.50 & 1.57 & 1.43 & 1.25 & 1.16 & 1.02 & nd & nd & nd & 0.09 & 0.16 & 0.23 & 0.10 & 0.11 & 0.21 & 0.31 & 0.46 & 0.00 & 0.29 & 0.23 & 0.19 & 0.17 \\
\hline Total & 98.35 & 97.66 & 98.43 & 98.75 & 98.39 & 97.17 & 96.61 & 96.17 & 95.67 & 96.49 & 97.32 & 96.93 & 97.91 & 95.54 & 94.23 & 95.72 & 97.43 & 96.24 & 97.48 & 98.02 & 96.44 & 96.08 \\
\hline OE $F$ & 0.63 & 0.66 & 0.6 & 0.53 & 0.49 & 0.43 & 0 & 0 & 0 & 0.04 & 0.07 & 0.1 & 0.04 & 0.05 & 0.09 & 0.13 & 0.19 & 0 & 0.12 & 0.1 & 0.08 & 0.07 \\
\hline $\mathrm{T} \overline{\mathrm{S}} \mathrm{i}$ & 7.257 & 7.441 & 7.419 & 7.452 & 7.599 & 7.257 & 6.407 & 6.493 & 6.429 & 6.467 & 6.401 & 6.365 & 6.241 & 6.422 & 6.417 & 6.352 & 6.457 & 6.449 & 6.437 & 6.435 & 6.518 & 6.522 \\
\hline TAl & 0.743 & 0.559 & 0.581 & 0.452 & 0.352 & 0.733 & 1.593 & 1.507 & 1.571 & 1.533 & 1.599 & 1.635 & 1.759 & 1.578 & 1.583 & 1.648 & 1.543 & 1.551 & 1.563 & 1.565 & 1.482 & 1.478 \\
\hline $\mathrm{TFe} 3$ & 0 & 0 & 0 & 0.096 & 0.049 & 0.01 & 0 & 0 & 0 & 0 & 0 & 0 & 0 & 0 & 0 & 0 & 0 & 0 & 0 & 0 & 0 & 0 \\
\hline $\mathrm{TTi}$ & 0 & 0 & 0 & 0 & 0 & 0 & 0 & 0 & 0 & 0 & 0 & 0 & 0 & 0 & 0 & 0 & 0 & 0 & 0 & 0 & 0 & 0 \\
\hline Sum_T & 8 & 8 & 8 & 8 & 8 & 8 & 8 & 8 & 8 & 8 & 8 & 8 & 8 & 8 & 8 & 8 & 8 & 8 & 8 & 8 & 8 & 8 \\
\hline $\mathrm{CA} \overline{\mathrm{I}}$ & 0.001 & 0.104 & 0.102 & 0 & 0 & 0 & 0.689 & 0.648 & 0.614 & 0.637 & 0.509 & 0.251 & 0.23 & 0.276 & 0.336 & 0.308 & 0.225 & 0.196 & 0.196 & 0.23 & 0.293 & 0.28 \\
\hline $\mathrm{CCr}$ & 0.137 & 0.114 & 0.111 & 0.071 & 0.05 & 0.133 & 0.006 & 0 & 0.004 & 0.004 & 0 & 0.01 & 0.001 & 0.001 & 0.007 & 0.008 & 0.01 & 0 & 0.021 & 0.013 & 0 & 0.009 \\
\hline $\mathrm{CFe} 3$ & 0.401 & 0.092 & 0.203 & 0.276 & 0.357 & 0.331 & 0.291 & 0.296 & 0.47 & 0.385 & 0.588 & 0.489 & 0.645 & 0.403 & 0.16 & 0.461 & 0.447 & 0.374 & 0.38 & 0.389 & 0.203 & 0.123 \\
\hline $\mathrm{CT} i$ & 0.006 & 0 & 0.01 & 0.003 & 0.01 & 0 & 0.095 & 0.111 & 0.092 & 0.101 & 0.088 & 0.126 & 0.131 & 0.136 & 0.134 & 0.132 & 0.169 & 0.173 & 0.157 & 0.199 & 0.185 & 0.182 \\
\hline $\mathrm{CMg}$ & 3.777 & 3.732 & 3.681 & 3.89 & 3.861 & 3.704 & 1.902 & 1.976 & 2.015 & 1.931 & 2.019 & 0.062 & 0.075 & 0.065 & 0.048 & 0.03 & 0.1 & 0.089 & 0.103 & 0.107 & 0.091 & 0.117 \\
\hline $\mathrm{CFe} 2$ & 0.644 & 0.922 & 0.86 & 0.719 & 0.678 & 0.791 & 1.991 & 1.946 & 1.774 & 1.908 & 1.762 & 3.953 & 3.807 & 3.998 & 4.208 & 3.952 & 3.96 & 4.084 & 4.061 & 3.979 & 4.148 & 4.212 \\
\hline $\mathrm{CM} \Omega$ & 0.034 & 0.036 & 0.033 & 0.041 & 0.044 & 0.041 & 0.027 & 0.023 & 0.032 & 0.035 & 0.034 & 0.109 & 0.112 & 0.122 & 0.107 & 0.109 & 0.089 & 0.084 & 0.082 & 0.083 & 0.078 & 0.078 \\
\hline $\mathrm{CCa}$ & 0 & 0 & 0 & 0 & 0 & 0 & 0 & 0 & 0 & 0 & 0 & 0 & 0 & 0 & 0 & 0 & 0 & 0 & 0 & 0 & 0 & 0 \\
\hline Sum_C & 5 & 5 & 5 & 5 & 5 & 5 & 5 & 5 & 5 & 5 & 5 & 5 & 5 & 5 & 5 & 5 & 5 & 5 & 5 & 5 & 5 & 5 \\
\hline $\mathrm{BMg}$ & 0 & 0 & 0 & 0 & 0 & 0 & 0 & 0 & 0 & 0 & 0 & 0 & 0 & 0 & 0 & 0 & 0 & 0 & 0 & 0 & 0 & 0 \\
\hline $\mathrm{BFe} 2$ & 0 & 0 & 0 & 0 & 0 & 0 & 0 & 0 & 0 & 0 & 0 & 0 & 0 & 0 & 0 & 0 & 0 & 0 & 0 & 0 & 0 & 0 \\
\hline BMin & 0 & 0 & 0 & 0 & 0 & 0 & 0 & 0 & 0 & 0 & 0 & 0 & 0 & 0 & 0 & 0 & 0 & 0 & 0 & 0 & 0 & 0 \\
\hline $\mathrm{BCa}$ & 1.891 & 1.937 & 1.884 & 1.931 & 1.889 & 1.933 & 1.924 & 1.915 & 1.89 & 1.905 & 1.903 & 1.849 & 1.833 & 1.841 & 1.905 & 1.863 & 1.792 & 1.835 & 1.868 & 1.783 & 1.84 & 1.879 \\
\hline $\mathrm{BNa}$ & 0.109 & 0.063 & 0.116 & 0.069 & 0.111 & 0.067 & 0.076 & 0.085 & 0.11 & 0.095 & 0.097 & 0.151 & 0.167 & 0.159 & 0.095 & 0.137 & 0.208 & 0.165 & 0.132 & 0.217 & 0.16 & 0.121 \\
\hline Sum_B & 2 & 2 & 2 & 2 & 2 & 2 & 2 & 2 & 2 & 2 & 2 & 2 & 2 & 2 & 2 & 2 & 2 & 2 & 2 & 2 & 2 & 2 \\
\hline $\mathrm{ACa}$ & 0 & 0 & 0 & 0 & 0 & 0 & 0 & 0 & 0 & 0 & 0 & 0 & 0 & 0 & 0 & 0 & 0 & 0 & 0 & 0 & 0 & 0 \\
\hline ANa & 0.2 & 0.232 & 0.176 & 0.216 & 0.054 & 0.243 & 0.371 & 0.315 & 0.294 & 0.298 & 0.31 & 0.407 & 0.42 & 0.424 & 0.522 & 0.364 & 0.402 & 0.455 & 0.431 & 0.41 & 0.424 & 0.477 \\
\hline $\mathrm{AK}$ & 0.101 & 0.08 & 0.086 & 0.047 & 0.033 & 0.102 & 0.124 & 0.11 & 0.116 & 0.102 & 0.113 & 0.378 & 0.367 & 0.362 & 0.385 & 0.381 & 0.33 & 0.345 & 0.354 & 0.342 & 0.35 & 0.346 \\
\hline Sum_A & 0.301 & 0.312 & 0.262 & 0.263 & 0.086 & 0.345 & 0.494 & 0.426 & 0.41 & 0.4 & 0.423 & 0.784 & 0.787 & 0.786 & 0.907 & 0.745 & 0.732 & 0.8 & 0.785 & 0.752 & 0.774 & 0.823 \\
\hline Sum ca & 15.301 & 15.312 & 15.262 & $\{5.263$ & 15.086 & 15.345 & 15.494 & 15.426 & 15.41 & 15.4 & 15.423 & 15.784 & 15.787 & 15.786 & 15.907 & 15.745 & 15.732 & 15.8 & 15.785 & 15.752 & 15.774 & 15.823 \\
\hline $\mathrm{CF}$ & 0.682 & 0.72 & 0.648 & 0.564 & 0.52 & 0.469 & 0 & 0 & 0 & 0.043 & 0.076 & 0.12 & 0.051 & 0.058 & 0.113 & 0.164 & 0.238 & 0 & 0.151 & 0.118 & 0.099 & 0.09 \\
\hline Sum $\mathrm{O}$ & 23 & 23 & 23 & 23 & 23 & 23 & 23 & 23 & 23 & 23 & 23 & 23 & 23 & 23 & 23 & 23 & 23 & 23 & 23 & 23 & 23 & 23 \\
\hline
\end{tabular}

Tab.VI.3: Análises químicas por microssonda eletrônica de anfibólios de rochas metaultramáficas (CP-5), anfibolitos (HM-10), Ortognaisse com Anfibólio e Biotita (S-12) e Ortognaisse com Anfibólio e Biotita mais foliado (S-10). 


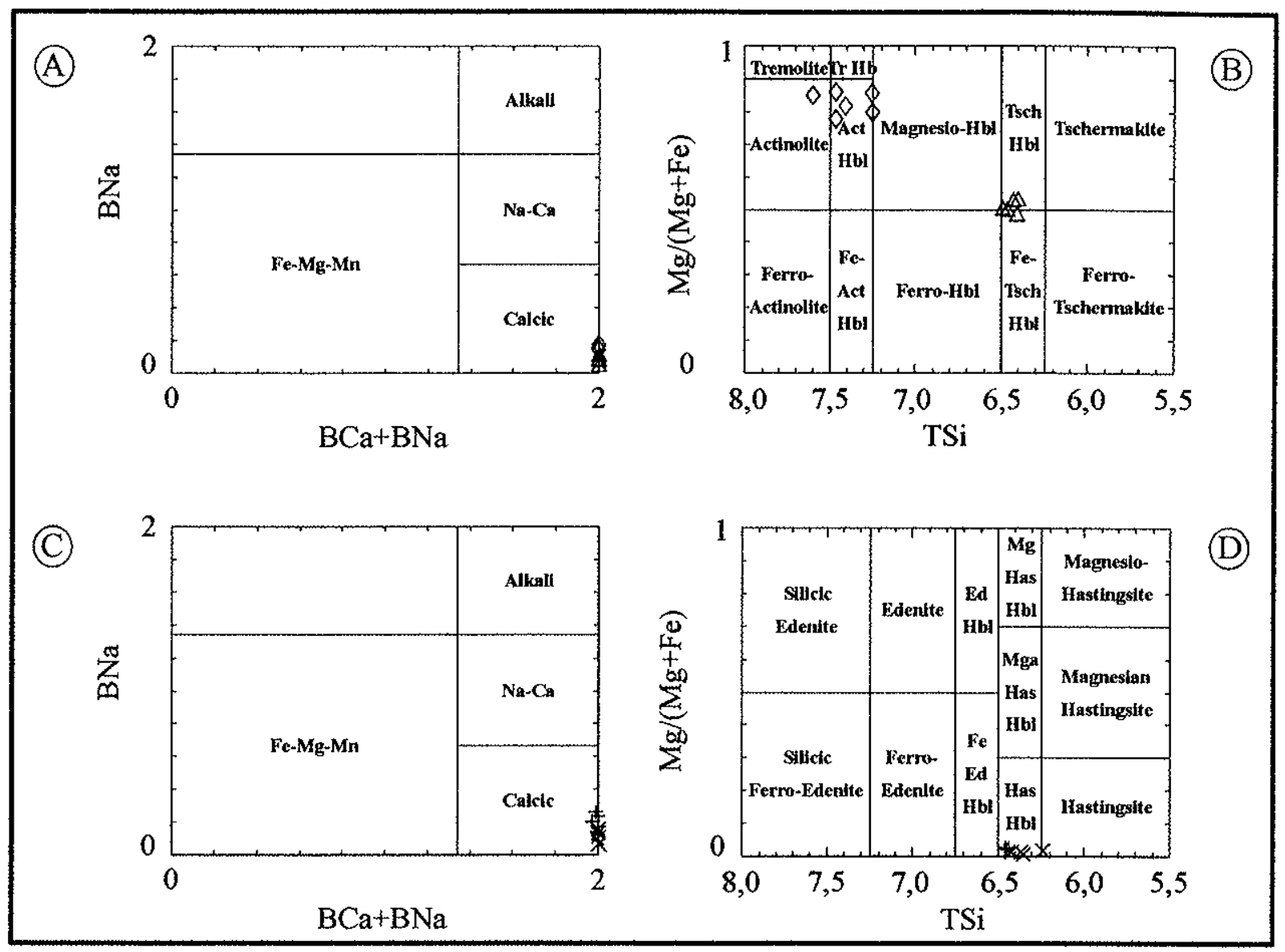

Fig.VI.7: Classificação dos anfibólios:

(A) no diagrama dos quatro grupos principais e (B) dentro do grupo de anfibólios cálcicos com $\mathrm{ANa}+\mathrm{AK}<0,5 ; \mathrm{Ti}<0,5$.

(C) no diagrama dos quatro grupos principais e (D) dentro do grupo de anfibólios cálcicos com $\mathrm{ANa}+\mathrm{AK}>0,5 ; \mathrm{Ti}<0,5 ; \mathrm{Fe}^{3+}>\mathrm{Al}^{\mathrm{VI}}$.

Anfibólios de Ortognaisse com Anfibólio e Biotita (+), Ortognaisse com Anfibólio e Biotita mais foliado $(x)$, anfibolitos $(\Delta)$, metaultramáficas $(0)$.

\section{VI.C.2. Micas}

Os resultados das análises químicas em flogopitas de rochas metaultramáficas (flogopititos) e biotitas do Ortognaisse Açucena encontram-se na tabela VI.4. 


\begin{tabular}{|c|c|c|c|c|c|c|c|c|c|c|c|c|c|c|c|c|c|c|c|c|c|c|c|c|}
\hline amostra & $\mathrm{CP}-5$ & CP-5 & CP-5 & CP-5 & CP-5 & $C P-5$ & S-1 & S-l & $\mathrm{S}-1$ & S-1 & S-1 & S-1 & $\mathrm{S}-10$ & S-10 & $S-10$ & S-10 & $\mathrm{S}-10$ & S-10 & S-12 & $S-12$ & $\mathrm{~S}-12$ & $S-12$ & S-12 & S-12 \\
\hline ponto & 21 & 20 & 19 & 7 & 8 & 6 & 15 & 14 & 13 & 18 & 17 & 16 & 3 & 2 & 1 & 7 & 9 & 8 & 3 & 2 & 1 & 11 & 12 & 10 \\
\hline $\mathrm{SiO} 2$ & 42.26 & 42.21 & 42.06 & 41.75 & 41.73 & 42.01 & 33.07 & 33.61 & 33.71 & 33.84 & 34.19 & 34.41 & 33.72 & 33.31 & 33.46 & 33.36 & 32.30 & 33.70 & 34.09 & 33.40 & 33.97 & 33.11 & 33.27 & 33.33 \\
\hline $\mathrm{TiO} 2$ & 0.33 & 0.42 & 0.39 & 0.22 & 0.30 & 0.29 & 1.92 & 1.80 & 1.90 & 1.85 & 2.23 & 2.13 & 2.88 & 2.56 & 2.90 & 3.25 & 3.25 & 3.35 & 3.53 & 3.30 & 3.44 & 3.09 & 2.91 & 3.24 \\
\hline $\mathrm{A} 12 \mathrm{O} 3$ & 11.48 & 11.83 & 12.16 & 11.61 & 11.99 & 12.01 & 17.81 & 18.12 & 17.75 & 17.58 & 17.27 & 17.40 & 13.68 & 13.59 & 13.60 & 13.38 & 13.63 & 13.45 & 12.86 & 13.06 & 12.97 & 12.95 & 13.67 & 13.12 \\
\hline $\mathrm{C} 22 \mathrm{O} 3$ & 0.60 & 0.68 & 0.78 & 0.27 & 0.41 & 0.42 & nd & 0.02 & nd & 0.10 & nd & nd & nd & 0.04 & 0.03 & 0.09 & nd & 0.06 & nd & nd & 0.03 & 0.02 & nd & 0.07 \\
\hline $\mathrm{FeO}$ & 8.27 & 8.20 & 8.60 & 8.34 & 8.41 & 8.58 & 31.05 & 31.05 & 30.34 & 30.94 & 30.46 & 30.67 & 34.85 & 34.87 & 34.37 & 35.08 & 33.55 & 34.38 & 36.61 & 34.90 & 34.53 & 34.28 & 35.25 & 34.88 \\
\hline $\mathrm{MnO}$ & nd & 0.10 & 0.12 & 0.13 & 0.11 & 0.11 & 0.37 & 0.39 & 0.37 & 0.36 & 0.45 & 0.37 & 0.56 & 0.62 & 0.56 & 0.25 & 0.50 & 0.48 & 0.33 & 0.34 & 0.35 & 0.25 & 0.32 & 0.33 \\
\hline $\mathrm{MgO}$ & 21.72 & 21.00 & 21.12 & 21.39 & 21.01 & 21.34 & 0.11 & 0.13 & nd & 0.05 & 0.05 & 0.20 & 0.31 & 0.28 & 0.41 & 0.37 & 0.29 & 0.36 & 0.62 & 0.50 & 0.58 & 0.59 & 0.60 & 0.55 \\
\hline $\mathrm{BaO}$ & 0.13 & nd & 0.28 & 0.31 & 0.19 & 0.01 & nd & nd & nd & 0.06 & nd & 0.18 & $n d$ & 0.12 & 0.09 & 0.08 & 0.24 & 0.20 & 0.15 & nd & 0.26 & nd & 0.41 & 0.41 \\
\hline $\mathrm{CaO}$ & nd & nd & nd & nd & nd & nd & nd & nd & nd & nd & nd & nd & nd & $\mathrm{nd}$ & nd & nd & nd & nd & nd & 0.09 & 0.02 & 0.03 & 0.04 & nd \\
\hline $\mathrm{Na} 2 \mathrm{O}$ & 0.32 & 0.36 & 0.40 & 0.34 & 0.32 & 0.27 & 0.03 & 0.07 & nd & nd & 0.15 & 0.05 & 0.02 & nd & nd & 0.10 & nd & nd & 0.29 & nd & 0.04 & 0.15 & nd & nd \\
\hline $\mathrm{K} 20$ & 9.83 & 9.74 & 9.89 & 9.76 & 9.81 & 9.99 & 9.38 & 9.28 & 9.52 & 9.43 & 9.31 & 9.31 & 9.37 & 9.26 & 9.03 & 9.10 & 9.00 & 8.88 & 8.93 & 8.69 & 8.80 & 9.07 & 8.57 & 8.90 \\
\hline$F$ & 3.42 & 3.34 & 3.20 & 3.39 & 3.33 & 3.25 & 0.94 & 0.64 & 0.96 & 0.72 & 1.05 & 0.87 & 0.43 & 0.12 & 0.32 & 0.26 & 0.45 & 0.43 & 0.50 & 0.30 & 0.34 & 0.39 & 0.52 & 0.30 \\
\hline Total & 98.36 & 97.88 & 98.99 & 97.52 & 97.62 & 98.28 & 94.67 & 95.10 & 99.55 & 94.93 & 95.16 & 95.58 & 95.81 & 94.92 & 94.77 & 95.32 & 93.20 & 95.30 & 97.89 & 94.60 & 95.33 & 93.94 & 95.55 & 95.14 \\
\hline $\mathrm{Si}$ & 6.118 & 6.126 & 6.059 & 6.11 & 6.092 & 6.084 & 5.651 & 5.682 & 5.775 & 5.758 & 5.828 & 5.821 & 5.752 & 5.731 & 5.747 & 5.714 & 5.673 & 5.767 & 5.701 & 5.739 & 5.807 & 5.761 & 5.666 & 5.723 \\
\hline AlIV & 1.957 & 2.022 & 2.063 & 2.001 & 2.061 & 2.048 & 2.349 & 2.318 & 2.225 & 2.242 & 2.172 & 2.179 & 2.248 & 2.269 & 2.253 & 2.286 & 2.327 & 2.233 & 2.299 & 2.261 & 2.193 & 2.239 & 2.334 & 2.277 \\
\hline AlVI & 0 & 0 & 0 & 0 & 0 & 0 & 1.235 & 1.289 & 1.356 & 1.281 & 1.295 & 1.287 & 0.5 & 0.484 & 0.498 & 0.413 & 0.492 & 0.478 & 0.234 & 0.382 & 0.418 & 0.415 & 0.408 & 0.376 \\
\hline $\mathrm{Ti}$ & 0.036 & 0.046 & 0.042 & 0.024 & 0.033 & 0.032 & 0.247 & 0.229 & 0.245 & 0.237 & 0.286 & 0.271 & 0.37 & 0.331 & 0.375 & 0.419 & 0.429 & 0.431 & 0.444 & 0.426 & 0.442 & 0.404 & 0.373 & 0.418 \\
\hline $\mathrm{Fe} 3$ & 0 & 0 & 0 & 0 & 0 & 0 & 0 & 0 & 0 & 0 & 0 & 0 & 0 & 0 & 0 & 0 & 0 & 0 & 0 & 0 & 0 & 0 & 0 & 0 \\
\hline $\mathrm{Fe} 2$ & 1.001 & 0.995 & 1.036 & 1.021 & 1.027 & 1.039 & 4.437 & 4.39 & 4.347 & 4.403 & 4.342 & 4.339 & 4.971 & 5.017 & 4.937 & 5.025 & 4.928 & 4.921 & 5.12 & 5.015 & 4.936 & 4.988 & 5.021 & 5.009 \\
\hline$C_{T}$ & 0.069 & 0.078 & 0.089 & 0.031 & 0.047 & 0.048 & 0 & 0.003 & 0 & 0.013 & 0 & 0 & 0 & 0.005 & 0.004 & 0.012 & 0 & 0.008 & 0 & 0 & 0.004 & 0.003 & 0 & 0.009 \\
\hline $\mathrm{Mn}$ & 0 & 0.012 & 0.015 & 0.016 & 0.014 & 0.013 & 0.054 & 0.056 & 0.054 & 0.052 & 0.065 & 0.053 & 0.081 & 0.09 & 0.081 & 0.036 & 0.074 & 0.07 & 0.047 & 0.049 & 0.051 & 0.037 & 0.046 & 0.048 \\
\hline $\mathrm{Mg}$ & 4.688 & 4.543 & 4.536 & 4.667 & 4.573 & 4.607 & 0.028 & 0.033 & 0 & 0.013 & 0.013 & 0.05 & 0.079 & 0.072 & 0.105 & 0.094 & 0.076 & 0.092 & 0.155 & 0.128 & 0.148 & 0.153 & 0.152 & 0.141 \\
\hline $\mathrm{Ba}$ & 0.007 & 0 & 0.016 & 0.018 & 0.011 & 0.001 & 0 & 0 & 0 & 0.004 & 0 & 0.012 & 0 & 0.008 & 0.006 & 0.005 & 0.017 & 0.013 & 0.01 & 0 & 0.017 & 0 & 0.027 & 0.028 \\
\hline $\mathrm{Ca}$ & 0 & 0 & 0 & 0 & 0 & 0 & 0 & 0 & 0 & 0 & 0 & 0 & 0 & 0 & 0 & 0 & 0 & 0 & 0 & 0.017 & 0.004 & 0.006 & 0.007 & 0 \\
\hline $\mathrm{Na}$ & 0.09 & 0.101 & 0.112 & 0.096 & 0.091 & 0.076 & 0.01 & 0.023 & 0 & 0 & & 0.016 & 0.007 & 0 & & 0.033 & 0 & 0 & 0.094 & $\begin{array}{c}.017 \\
0\end{array}$ & 0.013 & 0.051 & $\begin{array}{c}.007 \\
0\end{array}$ & 0 \\
\hline $\mathrm{K}$ & 1.816 & 1.803 & 1.818 & 1.822 & 1.827 & 1.846 & 2.045 & 2.001 & 2.081 & 2.047 & 2.025 & 2.009 & 2.039 & 2.032 & 1.979 & 1.988 & 2.017 & 1.939 & 1.905 & 1.905 & 1.919 & 2.0 & 1.862 & 1.95 \\
\hline Cations & 15.782 & 15.726 & 15.786 & 15.806 & 15.776 & 15.794 & 16.056 & 16.024 & 16.083 & 16.05 & 16.076 & 16.037 & 16.047 & 16.039 & 15.985 & 16.025 & 16.033 & 15.952 & 16.009 & 15.922 & 15.952 & 16.07 & 15.896 & 15.979 \\
\hline $\mathrm{CF}$ & 3.132 & 3.066 & 2.916 & 3.138 & 3.075 & 2.977 & 0.508 & 0.342 & 0.52 & 0.387 & 0.566 & 0.465 & 0.232 & 0.065 & 0.174 & 0.141 & 0.25 & 0.233 & 0.264 & 0.163 & 0.184 & 0.215 & 0.28 & 0.163 \\
\hline 0 & 24 & 24 & 24 & 24 & 24 & 24 & 24 & 24 & 24 & 24 & 24 & 24 & 24 & 24 & 24 & 24 & 24 & 24 & 24 & 24 & 24 & 24 & 24 & 24 \\
\hline Fe FeMg & 0.18 & 0.18 & 0.19 & 0.18 & 0.18 & 0.18 & 0.99 & 0.99 & 1 & $i$ & 1 & 0.99 & 0.98 & 0.99 & 0.98 & 0.98 & 0.98 & 0.98 & 0.97 & 0.98 & 0.97 & 0.97 & 0.97 & 0.97 \\
\hline $\mathrm{Mg}_{-} \mathrm{FeM}$ & 0.82 & 0.82 & 0.81 & 0.82 & 0.82 & 0.82 & 0.01 & 0.01 & 0 & 0 & 0 & 0.01 & 0.02 & 0.01 & 0.02 & 0.02 & 0.02 & 0.02 & 0.03 & 0.02 & 0.03 & 0.03 & 0.03 & 0.03 \\
\hline
\end{tabular}

Tab.VI.4: Análises químicas por microssonda eletrônica de flogopitas de rochas metaultramáficas (CP-5) e biotitas de Ortognaisse com Anfibólio e Biotita (S-10, 12) e Ortognaisse com Biotita (S-1). 
Assim como o anfibólio encontrado no flogopitito, a flogopita também apresenta teores elevados em $\mathrm{Cr}_{2} \mathrm{O}_{3}$ e $\mathrm{F}$ em relação à biotita das rochas ortognáissicas, respectivamente entre 0,27 a $0,78 \%$ e 3,2 a 3,42\%, em comparação com teores nos gnaisses não superiores a 0,1 e 1,0\%.

No diagrama de classificação (Fig.Vl.8), as biotitas das rochas ortognáissicas situam-se entre annita e siderofilita, com tendência para o vértice da annita, não se observando diferenças entre os tipos de gnaisses.

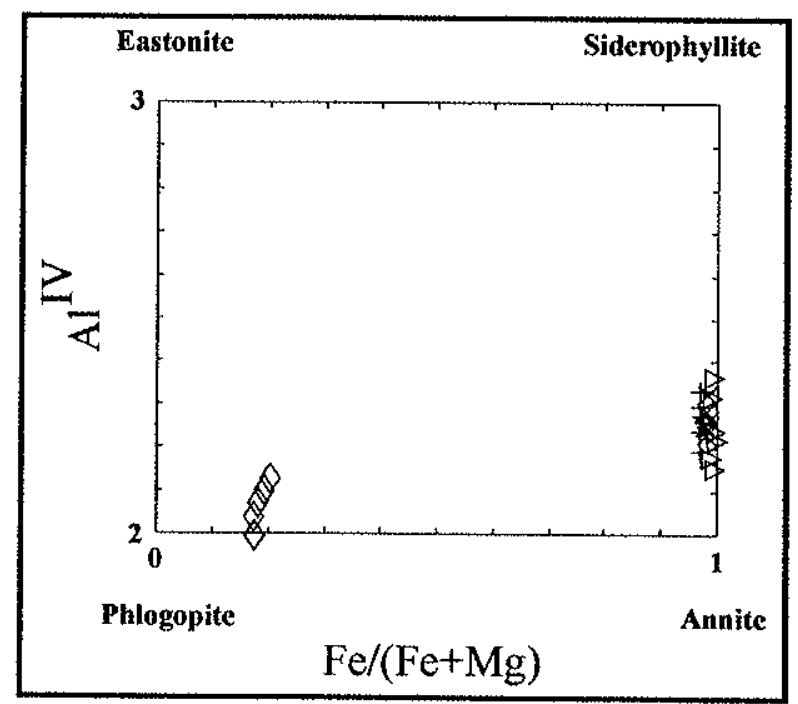

Fig.VI.8: Classificação de micas provenientes de Ortognaisse com Anfibólio e Biotita $(+)$, Ortognaisse com Anfibólio e Biotita mais foliado $(x)$, Ortognaisse com Biotita $(D)$ e metaultramáficas $(0)$.

\section{VI.C.3. Cromitas}

Cromita ocorre em rochas metaultramáficas do garimpo de esmeraldas de Córrego das Pedras, na forma de grãos euedrais, equidimensionais, de dimensões inferiores a $0,5 \mathrm{~mm}$, disseminados ou formando níveis quase monominerálicos.

As composições químicas dessas cromitas (Tab.VI.5) permitem classificálas, em termos dos membros puros cromita - magnetita - hercynita, como ferricromitas (Fig.VI.9). Comparando-se os resultados das análises efetuadas no centro e na borda de cada grão, torna-se evidente a existência de zoneamento composicional, com descréscimo dos teores em $\mathrm{Cr}_{2} \mathrm{O}_{3}$ acompanhado por aumento em $\mathrm{Fe}_{2} \mathrm{O}_{3}$ do centro para as bordas (Fig. VI.10). 


\begin{tabular}{|c|c|c|c|c|c|c|c|c|c|c|}
\hline $\begin{array}{c}\text { amostra } \\
\text { grăo }\end{array}$ & $\begin{array}{c}\text { CP-4a } \\
1 \text { centro }\end{array}$ & $\begin{array}{c}\text { CP-4a } \\
1 \text { borda }\end{array}$ & $\begin{array}{c}\mathrm{CP}-4 a \\
2 \text { centro }\end{array}$ & $\begin{array}{c}\mathrm{CP}-4 \mathrm{a} \\
2 \text { borda }\end{array}$ & $\begin{array}{c}C P-4 a \\
3 \text { centro }\end{array}$ & $\begin{array}{c}\text { CP-4a } \\
3 \text { borda }\end{array}$ & $\begin{array}{c}C P-4 a \\
4 \text { centro }\end{array}$ & $\begin{array}{l}C P-4 a \\
4 \text { borda }\end{array}$ & $\begin{array}{c}\text { CP-4a } \\
6 \text { centro }\end{array}$ & $\begin{array}{l}C P-4 a \\
6 \text { borda }\end{array}$ \\
\hline $\mathrm{SiO}_{2}$ & 0.13 & 0.28 & 0,20 & 0.23 & 0.21 & 0.21 & 0.13 & 0.20 & 0.18 & 0.22 \\
\hline $\mathrm{TiO}_{2}$ & 0.15 & 0.03 & 0.21 & 0.25 & 0.16 & 0.05 & 0.05 & 0.28 & 0.19 & 0.13 \\
\hline $\mathrm{Al}_{2} \mathrm{O}_{3}$ & 4.30 & 4.35 & 3.30 & 3.32 & 3.24 & 3.23 & 3.76 & 3.84 & 3.13 & 3.16 \\
\hline $\mathrm{Cr}_{2} \mathrm{O}_{3}$ & 51.55 & 50.61 & 51.49 & 49.29 & 54.03 & 51.55 & 52.18 & 49.88 & 52.38 & 49.83 \\
\hline Zno & 2.27 & 2.19 & 2.76 & 2.44 & 2.54 & 2.74 & 2.13 & 2.14 & 4.20 & 4.08 \\
\hline $\mathrm{FeO}$ & 26.56 & 26.32 & 25.87 & 26.16 & 26.69 & 26.13 & 26.72 & 26.34 & 25.09 & 24.56 \\
\hline $\mathrm{Fe}_{2} \mathrm{O}_{3}$ & 11.78 & 11.68 & 11.76 & 14.45 & 9.92 & 12.70 & 11.73 & 13.13 & 12.02 & 13.97 \\
\hline $\mathrm{MnO}$ & 1.23 & 1.15 & 1.48 & 1.45 & 1.44 & 1.40 & 1.35 & 1.36 & 1.65 & 1.75 \\
\hline $\mathrm{MgO}$ & 0.68 & 0.72 & 0.34 & 0.31 & 0.36 & 0.39 & 0.58 & 0.54 & 0.17 & 0.15 \\
\hline $\mathrm{NiO}$ & 0.14 & 0.06 & 0.10 & nd & 0.07 & 0.02 & nd & 0.01 & 0.09 & 0.05 \\
\hline Total & 98.79 & 97.40 & 97.51 & 97.91 & 98.66 & 98.42 & 98.62 & 97.72 & 99.09 & 97.90 \\
\hline
\end{tabular}

\begin{tabular}{|c|cccccccc|}
\hline $\begin{array}{c}\text { amostra } \\
\text { grão }\end{array}$ & $\begin{array}{c}\text { CP-5 } \\
7 \text { centro }\end{array}$ & $\begin{array}{c}\mathrm{CP}-5 \\
7 \text { borda }\end{array}$ & $\begin{array}{c}\mathrm{CP}-5 \\
8 \text { centro }\end{array}$ & $\begin{array}{c}\mathrm{CP}-5 \\
8 \text { borda }\end{array}$ & $\begin{array}{c}\text { CP-5 } \\
9 \text { centro }\end{array}$ & $\begin{array}{c}\mathrm{CP}-5 \\
9 \text { borda }\end{array}$ & $\begin{array}{c}\text { CP-5 } \\
\text { 10 centro }\end{array}$ & $\begin{array}{c}\text { CP-5 } \\
10 \text { borda }\end{array}$ \\
\hline $\mathrm{SiO}_{2}$ & 0.09 & 0.17 & 0.06 & 0.18 & 0.46 & 0.16 & 0.11 & 0.10 \\
$\mathrm{TiO}_{2}$ & 0.29 & 0.26 & 0.29 & 0.27 & nd & 0.29 & 0.21 & 0.23 \\
$\mathrm{Al}_{2} \mathrm{O}_{3}$ & 3.11 & 2.92 & 3.00 & 3.02 & 3.38 & 3.19 & 3.01 & 3.19 \\
$\mathrm{Cr}_{2} \mathrm{O}_{3}$ & 52.56 & 51.30 & 50.65 & 49.90 & 51.81 & 49.85 & 53.39 & 51.03 \\
$\mathrm{ZnO}$ & 4.47 & 4.46 & 4.47 & 4.15 & 3.80 & 4.01 & 4.09 & 4.05 \\
$\mathrm{FeO}$ & 25.05 & 24.35 & 24.14 & 24.84 & 25.46 & 24.89 & 25.06 & 24.84 \\
$\mathrm{Fe}_{2} \mathrm{O}_{3}$ & 12.25 & 12.24 & 13.15 & 14.58 & 12.07 & 15.17 & 10.83 & 12.63 \\
$\mathrm{MnO}$ & 1.68 & 1.70 & 1.77 & 1.63 & 1.46 & 1.86 & 1.65 & 1.59 \\
$\mathrm{MgO}$ & 0.16 & 0.16 & 0.20 & 0.09 & 0.20 & 0.14 & 0.26 & 0.21 \\
$\mathrm{NiO}$ & nd & nd & 0.01 & 0.11 & nd & 0.13 & 0.04 & nd \\
Total & 99.65 & 97.56 & 97.73 & 98.77 & 98.34 & 99.69 & 98.65 & 97.87 \\
\hline
\end{tabular}

Tab.VI.5: Composição química de cromitas de tremolitito (amostra CP-4a) e flogopitito (amostra CP-5).

$\mathrm{FeO}$ e $\mathrm{Fe}_{2} \mathrm{O}_{3}$ : deteminados como $\mathrm{FeO}_{\mathrm{t}}$ e recalculados por estequiometria. 


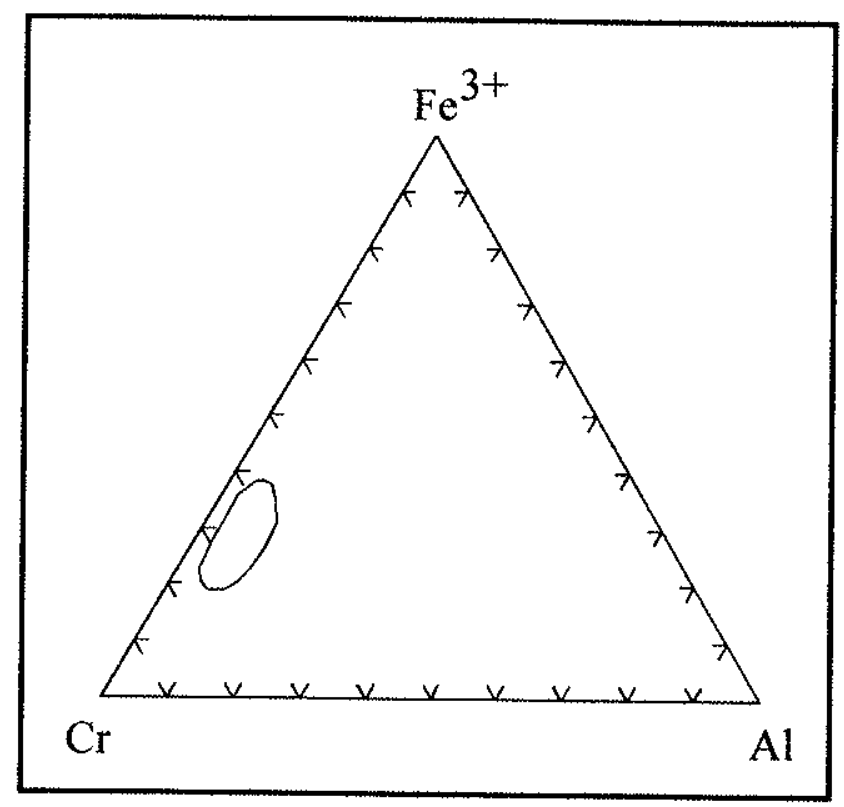

Fig.VI.9: Distribuição das composições das cromitas de tremolitito e flogopitito em função dos elementos $\mathrm{Cr}, \mathrm{Fe}^{3+}$ e Al.

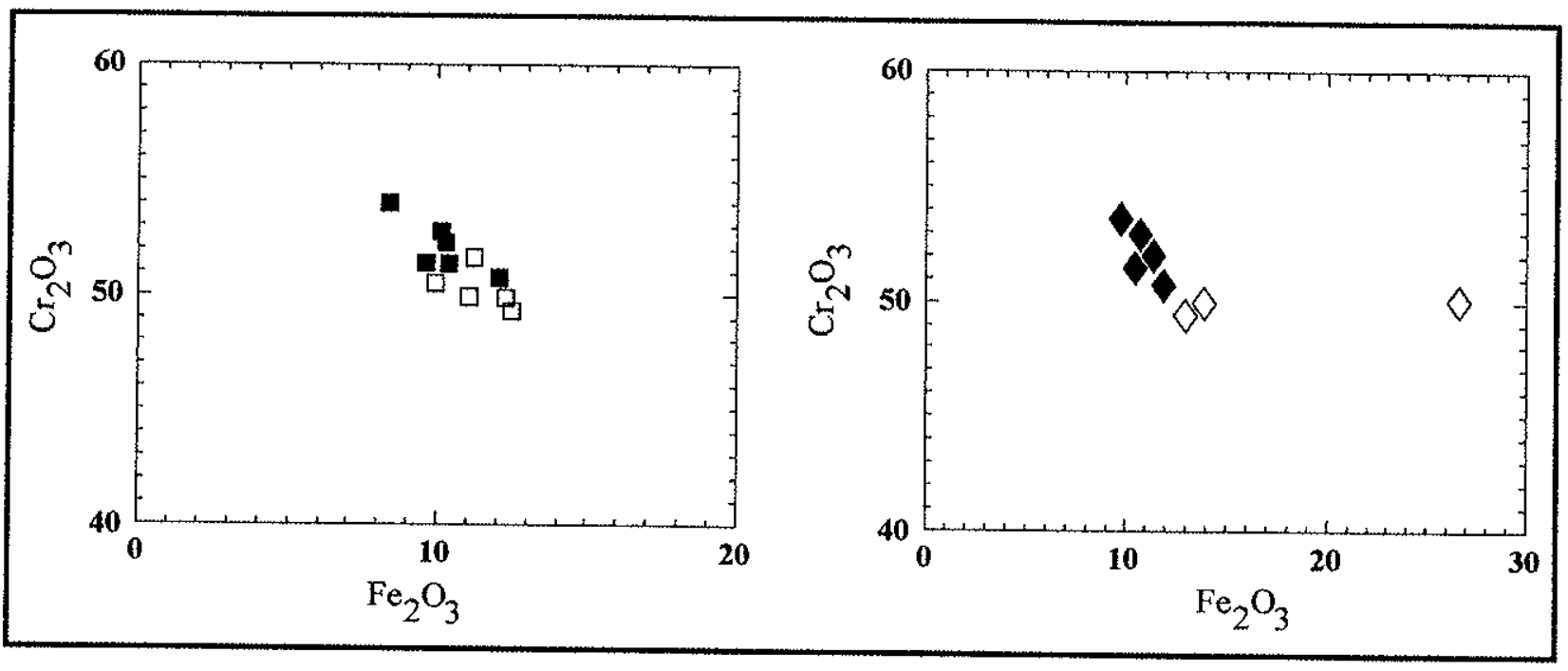

Fig.VI.10: Variação composicional de cromitas de tremolitito e flogopitito em função

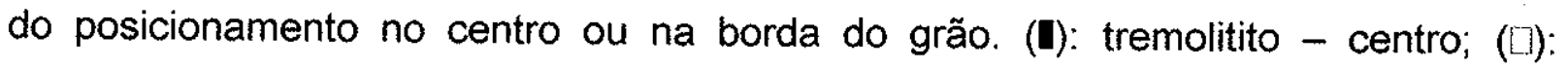
tremolitito - borda; $(\bullet)$ : flogopitito - centro; $(\diamond)$ : flogopitito - borda. 
Mudanças composicionais dessa natureza são descritas por Mohanty et al. (1996), que no entanto descrevem também um zoneamento marcante em microscopia de luz refletida, com um núcleo de cromita envolto por nível de ferricromita e magnetita, que não foi constatado nas cromitas analisadas neste trabalho. Estas apresentaram-se homogêneas em luz refletida e com um zoneamento composicional bem mais restrito.

A presença de zinco em cromitas tem sido atribuída por alguns autores (dentre eles Figueiras \& Waerenborgh 1997) a processos epigenéticos. Os resultados do presente trabalho parecem confirmar essa hipótese, uma vez que cromitas da rocha metaultramáfica mais intensamente metassomatizada (Amostra CP-5: flogopitito) apresentam teores em ZnO mais elevados (entre 3,80 e 4,47, com média de 4,19$)$ em relação às cromitas provenientes de um tremolitito (\%ZnO entre 2,13 e 4,20, com média de 2,75 ).

Teores semelhantes, de até $2,78 \% \mathrm{Zno}$, foram encontrados em cromitas do Supergrupo Rio das Velhas por Schorscher (1992), que vê no estudo desse mineral possibilidades de aplicação na investigação do ambiente geotectônico de formação de rochas metaultramáficas.

Seguindo-se esse raciocínio, e considerando-se que a natureza das rochas metaultramáficas aflorantes na região de estudo não é totalmente conhecida, as composições químicas das cromitas analisadas neste trabalho foram plotadas em

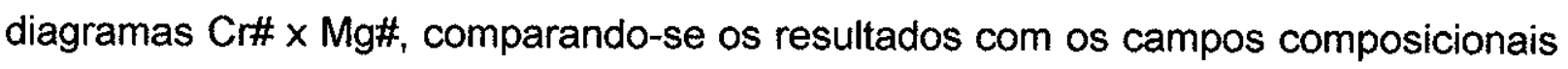
de cromitas de diversas ocorrências mundiais compiladas por Peltonen (1995) (Fig.VI.11).

Neste diagrama, as cromitas investigadas situaram-se próximo ao campo de cromitas de rochas ultramáficas cumuláticas, sobrepondo-se a ferricromitas de cumulados ultramáficos do depósito de Ni-Cu de Vammala, Finlândia (Peltonen 1995). 


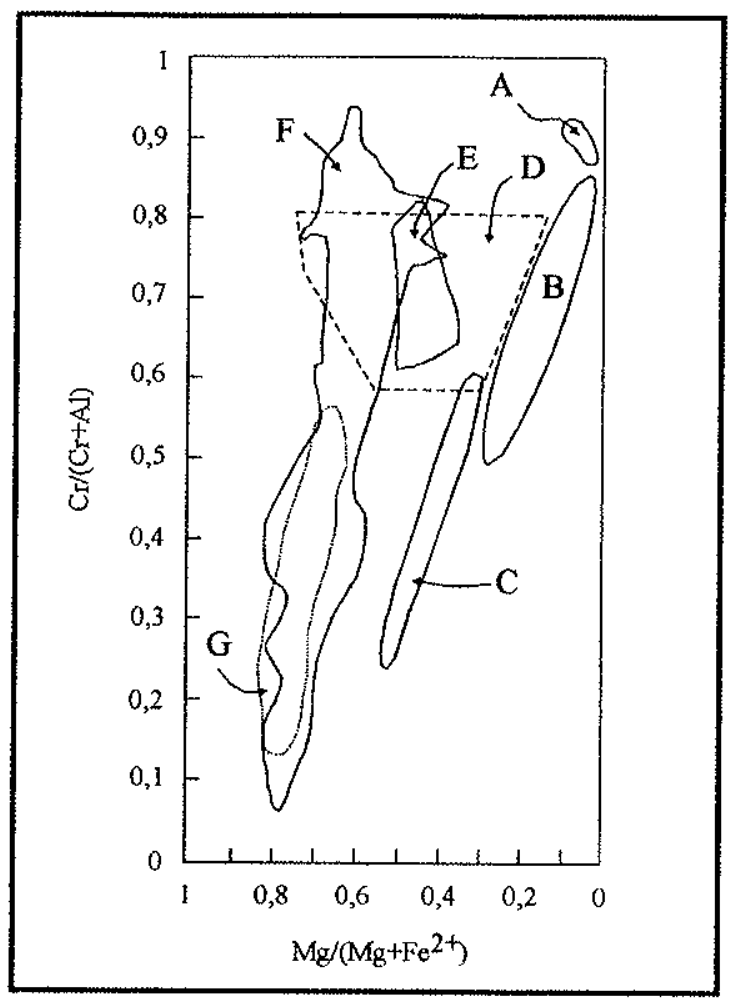

Fig.Vl.11: Composição das cromitas analisadas neste trabalho (A) em comparação com os campos composicionais de cromitas de cumulados ultramáficos $(B, C)$, intrusões acamadadas (D,E), peridotitos tipo alpino $(F)$ e peridotitos abissais $(G)$ (Peltonen 1995).

\section{VI.D. Metamorfismo e Deformação}

Segundo os estudos de Schorscher (1982), a estruturação e as paragêneses observadas atualmente na região do Quadrilátero Ferrífero e Espinhaço Meridional originaram-se principalmente no evento pós-Minas/Espinhaço, em condições de metamorfismo que variaram de fácies xisto verde superior a hidrogranulito (Fig.V.1). Ainda de acordo com as zonas metamórficas definidas pelo autor, na área abrangida neste trabalho foram atingidas condições de fácies anfibolito superior, caracterizadas pela reação muscovita + quartzo $=$ feldspato potássico + sillimanita $+\mathrm{H}_{2} \mathrm{O}$.

Neste item, a partir das texturas e paragêneses minerais descritas anteriormente para as litologias presentes na área de estudo, procede-se à caracterização das condições de metamorfismo e deformação atuantes, ainda que 
não tenham sido obtidos dados geotermobarométricos a partir de pares de minerais coexistentes.

As rochas graníticas, quando submetidas a metamorfismo e deformação, não apresentam paragêneses elucidativas do grau metamórfico, porém desenvolvem texturas indicativas das condições de recristalização (Bozkurt \& Park 1997, Hanmer 1982, Pryer 1993, Simpson 1985, Vollbrecht et al. 1997, dentre outros).

No Ortognaisse Açucena, a orientação da rocha é dada pela biotita, pelos aglomerados máficos e por grãos alongados de quartzo e feldspato potássico. No entanto, apesar do elemento planar, recristalização em condições de baixa deformação pode ser inferida a partir da ausência de grãos finos recristalizados ao redor de porfiroclastos (textura mortar). O padrão de recristalização apresentado pelo plagioclásio - desenvolvimento de subgrãos internamente ao grão original assemelha-se ao subtipo IIP descrito por Hanmer (1982) e atribuído pelo autor a condições de baixa deformação, em oposição ao desenvolvimento de bordas recristalizadas em resposta a altas taxas de deformação.

Outras feições descritas ainda em plagioclásios, tais como kink bands, extinção ondulante e geminação de origem mecânica, caracterizam deformação em estado plástico, possivel a temperaturas acima de $450-500^{\circ} \mathrm{C}$ (Voll 1976) ou $550^{\circ} \mathrm{C}$ (Tullis 1983).

A presença de geminação em grade no feldspato potássico impõe também um limite inferior de temperatura de $450^{\circ} \mathrm{C}$ para a cristalização da fase monoclínica e posterior inversão para microclínio (Ribbe 1983).

Essas temperaturas ao redor de $550^{\circ} \mathrm{C}$ indicam condições de metamorfismo no mínimo de fácies anfibolito inferior (Bucher \& Frey 1994), posicionando-se, em relação às isógradas de Schorscher (1992), a partir da isógrada da estaurolita (Fig.V.1).

A reação de substituição do anfibólio por biotita, na passagem do Ortognaisse com Anfibólio e Biotita para o Ortognaisse com Biotita, pode ser posicionada na transição entre fácies epídoto anfibolito e xisto verde com base na desestabilização da hornblenda e sua substituição por biotita castanho-esverdeada (Bucher \& Frey 1994).

Com relação às rochas metaultramáficas, os litotipos observados (talcotremolita-antofilita-clorita xisto, antofilita tremolitito, antofilita-tremolita-clorita xisto, 
actinolita-flogopita xisto e flogopitito) caracterizam o desenvolvimento de zonas de reação metassomática entre rocha ultramáfica e sua encaixante, à semelhança dos processos descritos por Curtis \& Brown (1969, 1971) e Sanford (1982).

$\mathrm{Na}$ seqüência de zonas de reação descritas por Sanford (1982): assembléia ultramáfica $\rightarrow$ talco + carbonato $\rightarrow$ talco $\rightarrow$ anfibólio cálcico + clorita $\rightarrow$ clorita $\rightarrow$ transição para encaixante $\rightarrow$ encaixante, os litotipos acima descritos parecem situar-se nas zonas do talco, anfibólio cálcico + clorita e clorita, embora a natureza máfica da encaixante na ocorrência estudada pelo autor não tenha permitido o desenvolvimento da zona da flogopita, como observado no presente trabalho. Esta encontra-se, no entanto, descrita por Curtis \& Brown (1969) na passagem para rocha encaixante de natureza granítica.

A presença de porfiroblastos não orientados de antofilita em matriz de tremolita e clorita, descritos no item VI.A.2.a, encontra explicação nas observações de Sanford (1982), segundo as quais condições de fácies anfibolito resultam na substituição parcial da zona do anfibólio cálcico + clorita por talco + antofilita.

Variações de grau metamórfico dentro da fácies anfibolito encontram-se impressas nas rochas anfibolíticas, que podem apresentar hornblenda verde-azulada como indicador de fácies anfibolito inferior (Bucher \& Frey 1994) ou clinopiroxênio (diopsídio), cuja formação, ao redor, de $650^{\circ} \mathrm{C}$ (Bucher \& Frey 1994), sugere que condições de fácies anfibolito superior foram atingidas.

Deve-se considerar ainda a presença de veios quartzo-feldspáticos associados a esse anfibolito com clinopirozênio, representando o início de processos de fusão parcial.

Nas proximidades da Lavra de Hematita, a ocorrência de cianita-quartzomuscovita xisto sugere que, ao menos nessa região, condições de fácies anfibolito superior não foram alcançadas, não se dando a reação muscovita + quartzo = feldspato potássico + sillimanita (Bucher \& Frey 1994).

Em suma, a região em estudo mostrou-se afetada por condições de máximo metamorfismo de fácies anfibolito superior, com um evento retrometamórfico de fácies epídoto anfibolito/xisto verde associado à transformação do Ortognaisse com Anfibólio e Biotita para Ortognaisse com Biotita. 
V.E. O Ortognaisse Açucena e o Granito Borrachudos

O Ortognaisse Açucena é aqui considerado um equivalente do Granito Borrachudos afetado por retrabalhamento proterozóico. Neste item, são apresentadas as evidências, texturais, mineralógicas e químicas, que sustentam essa correlação.

Quimicamente, os dois grupos de rochas são semelhantes, apresentando ambos alto teor em sílica (>74\% e entre 72,30 e $79,20 \%$, respectivamente para o Granito Borrachudos e o Ortognaisse Açucena) e caráter metaluminoso a peraluminoso, levemente $C$ normativo ( $C \leq 2 \%$ no Granito Borrachudos e $C \leq 0,2 \%$ no Ortognaisse Açucena).

Considerando-se o comportamento dos elementos traço mais o potássio em spidergram (Fig.VI.12), nota-se a similaridade entre o Ortognaisse Açucena e o Granito Borrachudos, este último nas suas ocorrências tipo estudadas por Schorscher (1992).

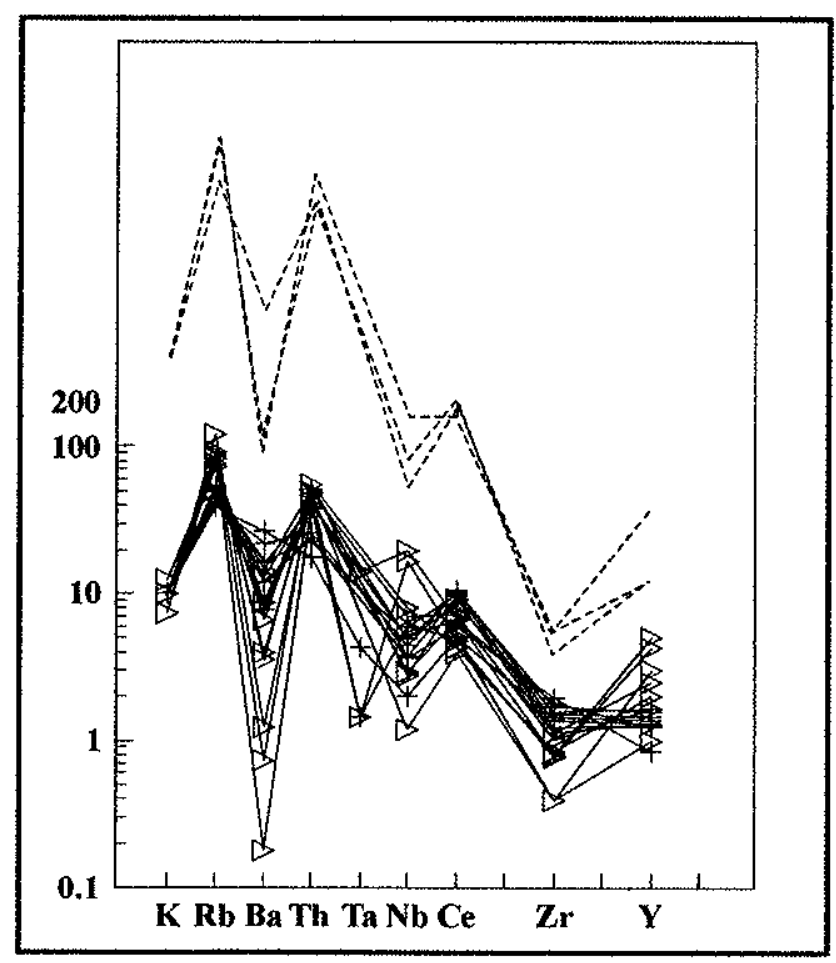

Fig.Vl.12: Comportamento dos elementos traço e $\mathrm{K} \mathrm{em}$ amostras de Ortognaisse com Anfibólio e Biotita $(+)$ e Ortognaisse com Biotita $(\triangleright)$ em spidergram com normalização por granitos de dorsal oceânica, em comparação com composições médias do Granito Borrachudos obtidas por Schorscher (1992) (tracejado). 
O posicionamento do Granito Borrachudos no diagrama triangular Ba-RbSr apresentado por Schorscher (1992) é também semelhante à distribuição do Ortognaisse Açucena no diagrama de El Bouseily \& El Sokkary (1975), apresentado na figura VI.3.

As composições modais refletem as composições químicas semelhantes dos dois grupos de rochas, porém registram ainda modificações mineralógicas no Ortognaisse Açucena devidas ao seu maior grau metamórfico. O feldspato alcalino pertítico, que perfaz 55\% no Granito Borrachudos, apresenta-se no Ortognaisse Açucena recristalizado em grãos individuais de feldspato potássico e plagioclásio albítico, tendo sido destruída uma das feições mais típicas do Granito Borrachudos, as mesopertitas de substituição.

No entanto, outra feição típica, a presença de aglomerados máficos, ainda persiste no Ortognaisse Açucena.

O mineral máfico predominante no Granito Borrachudos é a biotita, sendo a presença de anfibólio atribuída à cristalização metamórfica. No Ortognaisse Açucena aflorante nos arredores de Esmeraldas de Ferros, 0 anfibólio, que representa o principal mineral máfico, pode apresentar textura poiquiloblástica, o que condiz com a elevação do grau metamórfico da porção $W$, onde encontram-se as ocorrências tipo de Granito Borrachudos, para $E$, em direção a Esmeraldas de Ferros.

No entanto, condições menos elevadas de metamorfismo, representadas pela substituição do anfibólio por biotita + quartzo + fluorita no Ortognaisse Açucena, não foram relatadas no Granito Borrachudos. Ao contrário, Machado $(1994,1998)$ descreve a formação de anfibólio associada ao desenvolvimento do Metagranitóide Foliado com Fluorita, uma unidade texturalmente mais semelhante ao Ortognaisse com Biotita do Ortognaisse Açucena.

\section{VI.F. Ocorrências de Crisoberilo e Esmeralda}

$\mathrm{Na}$ região em estudo foram reconhecidas três áreas de ocorrência de crisoberilo, variedade alexandrita - Quilombo, Hematita e Esmeraldas de Ferros (Fig.I.1), concentrando-se os trabalhos nas duas últimas, que contam com atividades regulares de exploração. 
As dificuldades impostas pela presença do crisoberilo em depósito secundário (Quilombo e Hematita) ou na rocha in situ porém em estado de alteração elevado (Esmeraldas de Ferros) dificultaram as conclusões a respeito da gênese do material, assim como o alto grau de intemperismo e o difícil acesso prejudicaram uma visão detalhada do arcabouço geológico da área.

No entanto, a qualidade excepcional da alexandrita da Lavra de Hematita (Proctor 1988) e a rara oportunidade de observação do material in situ em Esmeraldas de Ferros justificaram a realização desta pesquisa.

Além disso, a proximidade com três áreas produtoras de esmeralda Cantagalo, Córrego das Pedras e Limeira (Fig.I.1) - todas na rocha primária, permitiu que algumas informações obtidas nestas últimas fossem também estendidas às áreas produtoras de crisoberilo.

\section{VI.F.1. Lavra de Esmeraldas de Ferros}

Nesta ocorrência primária, cristais pequenos de alexandrita, geralmente menores que $1 \mathrm{~cm}$, são encontrados em níveis quartzo-feldspáticos boudinados intercalados em um biotita xisto grafitoso de granulação grossa, já bastante alterado (Prancha 3-A, B, C).

Este horizonte mineralizado não ultrapassa $50 \mathrm{~cm}$ de espessura e encontra-se intercalado em um gnaisse também alterado, cuja principal característica é a grande variação composicional causada pela presença de niveis ora mais anfibolíticos ora mais biotíticos (Gnaisse Monlevade).

A orientação geral apresentada pelo gnaisse é 05-30NE/40-60NW, observando-se dobras decimétricas freqüentemente rompidas e lineação de estiramento mineral orientadas segundo $130 \% 40-50 \mathrm{NW}$. A alexandrita ocorre próximo às lineações, predominantemente no flanco superior das dobras (Karfunkel \& Wegner 1993), ou em veios quartzo-feldspáticos concordantes com a orientação da encaixante.

A exploração realiza-se pela remoção do estéril com retro-escavadeira e lavagem e catação manual do horizonte mineralizado, operações facilitadas pelo alto grau de intemperismo das rochas. 
A produção situa-se entre 2 e $3 \mathrm{~kg}$ de alexandrita por $30-40 \mathrm{~kg}$ de material lavado (Karfunkel \& Wegner 1993).

\section{VI.F.2. Lavra de Hematita}

Alexandrita, esmeralda, crisoberilo amarelo, olho-de-gato, água-marinha e ametista ocorrem em um conglomerado mal selecionado, onde predominam blocos e seixos arredondados de quartzo hialino ou fumê em matriz areno-argilosa. Fragmentos de cristais facetados de quartzo e blocos de anfibolitos e gnaisses também são freqüentes, sugerindo proximidade com a rochamfonte.

Ocorrem até três níveis de conglomerado produtivo, que podem estar recobertos por até $12 \mathrm{~m}$ de material areno-argiloso estéril, sendo possível reconhecer, dentro de cada nível, uma diminuição da granulometria da base para o topo (Prancha 4-A):

conglomerado arenoso, com seixos e blocos sub-arredondados, predominantemente de quartzo;

. areia grossa argilosa;

. argila arenosa;

. argila escura, com restos de troncos não carbonizados.

$\mathrm{Na}$ base do conglomerado aflora o embasamento em estado semialterado, um gnaisse leucocrático com bandamento fino, pouco pronunciado, localmente com bolsões quartzo-feldspáticos concordantes com a atitude da rocha.

Acima do gnaisse leucocrático ocorre uma rocha muito alterada, de coloração arroxeada, bandamento gnáissico, com niveis quartzo-feldspáticos concordantes formando por vezes bolsões pegmatíticos discordantes.

Um furo de sonda executado na área da lavra revelou a presença de um nivel espesso de anfibolito $(22 \mathrm{~m})$ sobreposto a um gnaisse com intercalações de níveis anfibolíticos, tipo Gnaisse Monlevade (item VI.A.2.c).

Após remoção do estéril com retro-escavadeira, o conglomerado é transportado para a área de beneficiamento, onde passa por lavagem, peneiramento (quatro peneiras) e finalmente catação manual. 
$O$ rejeito consiste de blocos, seixos e grânulos retidos nas peneiras e material fino oriundo da lavagem, que é separado em um tanque de decantação.

A montante dessa lavra, explorada pela Mineração Itaitinga, encontra-se a área pertencente à Alexandrita Mineração, onde foram noticiados os primeiros achados de alexandrita no ano de 1986 (Prancha 4-B). Segundo relatos colhidos por Proctor (1988), os niveis de cascalho mineralizado inicialmente explorados apresentavam-se ricos em caulim, sugerindo curto transporte ou até deposição in situ.

A $N$ da lavra observa-se uma escarpa muito abrupta alinhada segundo $E$ W, conhecida como Serra da Liberdade, que representa a passagem para a área de domínio do Ortognaisse Açucena (Prancha 4-C).

\section{VI.F.3. Ocorrência de Quilombo}

As três variedades de crisoberilo (comum, olho-de-gato e alexandrita) são encontradas em aluvião, em trabalhos realizados esporadicamente pelo proprietário do terreno.

As litologias observadas na área são um biotita gnaisse alterado, intensamente recortado por veios quartzo-feldspáticos, e biotitito, este último reconhecido apenas em blocos soltos.

Devido ao estágio incipiente da exploração e à dificuldade de acesso, esta ocorrência não foi alvo de estudos mais pormenorizados no âmbito desta pesquisa.

\section{VI.F.4. Lavra de Cantagalo}

Nesta ocorrência de esmeralda, a exploração é conduzida por meio de trabalhos subterrâneos, com um poço de aproximadamente $28 \mathrm{~m}$ de profundidade.

No nível de biotitito mineralizado, o qual não teria mais que $30 \mathrm{~cm}$ de espessura, são encontradas esmeraldas límpidas e pouco fraturadas, porém com cores fracas.

A rocha predominante na área é um biotita gnaisse cinza de granulação muito fina a fina $(\leq 1 \mathrm{~mm})$, com bandamento perfeitamente paralelo e aspecto listado, 
ressaltado ainda pela ocorrência de níveis anfibolíticos centimétricos, tipo Gnaisse Monlevade.

Durante a abertura do poço foram atravessados também niveis de granada-quartzo-biotita xisto de coloração cinza, granulação fina $(1-2 \mathrm{~mm})$, com porfiroblastos euedrais de granada escura (cor vinho a marrom) de até $5 \mathrm{~mm}$.

\section{VI.F.5. Ocorrência de Córrego das Pedras}

Esta ocorrência de esmeralda dispõe-se ao longo de um vale, cercado em ambos os lados por escarpas do Ortognaisse Açucena.

A exploração deu-se inicialmente em material aluvionar, porém a atual detentora dos direitos de exploração da área, Mineração Itaitinga, conduz a pesquisa através de trabalhos subterrâneos.

A mineralização dá-se em rochas metaultramáficas cortadas por veios quartzo-feldspáticos, reconhecendo-se flogopitito e a demais litologias já descritas no item VI.A.2.a.

Matacões de rochas metaultramáficas afloram nas proximidades, em local conhecido pelos moradores como Grota dos Paneleiros, onde há aproximadamente um século atrás eram produzidos utensílios de pedra-sabão.

\section{VI.F.6. Garimpo da Limeira}

Esta área encontra-se atualmente produzindo esmeraldas a partir de dois poços de aproximadamente $30 \mathrm{~m}$ de profundidade. O material, apesar da boa coloração, apresenta-se geralmente muito deformado.

A mineralização dá-se em um nível de flogopitito de espessura métrica que ocorre ao lado de actinolita-flogopita xisto e talco-tremolita-clorita xisto.

\section{VI.G. Minerais Pesados e Tipologia do Zircão}

Embora a natureza aluvionar da alexandrita da Lavra de Hematita não permita conclusões definitivas quanto à sua origem, o reconhecimento dos minerais 
constituintes do material sedimentar mostrou-se útil na identificação da possível rocha-fonte da mineralização.

Resultado interessante foi também obtido com a aplicação do método da tipologia do zircão, que permitiu considerações a respeito das rochas ígneas aflorantes na região.

\section{VI.G.1. Minerais pesados}

O rejeito mineral do tanque de decantação da Lavra de Hematita, constituído por fração areia, foi tratado para a separação dos pesados. Por meio de microscopia em luz refletida e transmitida, difratometria de raios $X$ e EDS, foram identificados os seguintes minerais:

. anfibólios (tremolita/actinolita)

. espinélio verde

. estaurolita

. granada

. hematita

. ilmenita

. magnetita

. ortopiroxênio

. rutilo

. sillimanita

. titanomagnetita

. zircão

Como constituintes do aluvião, porém já na fração de grânulos, foram ainda reconhecidos:

. berilo: verde-azulado, azul (água-marinha), verde (esmeralda)

. cianita

. crisoberilo amarelo

epídoto 
halloysita

. muscovita

. pirita

. quartzo: comum, fumê, ametista

. topázio

. xenotima

Os ambientes ou rochas-fonte sugeridos pelos minerais acima refletem as litologias constituintes do arcabouço geológico regional, ou seja, rochas ígneas (zircão), metamórficas de médio a alto grau (granada, estaurolita, cianita, sillimanita), rochas básicas/ultrabásicas (anfibólios, piroxênios, epídoto) e pegmatíticas (rutilo, quartzo, berilo, topázio, crisoberilo amarelo, muscovita).

A presença de minerais instáveis, como tramolita/actinolita e piroxênios (Pettijohn et al. 1973), associada às características do depósito de Hematita (conglomerado mal selecionado, com blocos de anfibolito e gnaisse e fragmentos de cristais facetados de quartzo), refletem o curto transporte e a deposição rápida do material sedimentar, características de ambiente de leques aluviais.

\section{VI.G.2 Tipologia do zircão}

O zircão constitui o mineral pesado transparente mais abundante, geralmente na forma de grãos de hábito prismático alongado, com faces e arestas bem preservadas e dimensões em torno de $0,1 \times 0,1 \times 0,3 \mathrm{~mm}$.

Para a aplicação do método da tipologia do zircão, foram analisados 100 grãos separados a partir da fração pesada do rejeito da Lavra de Hematita, constatando-se a predominância do hábito prismático simples, com desenvolvimento do prisma $\{100\}$ e pirâmide $\{101\}$, correspondente ao tipo $D$ na classificação de Pupin (1980).

Além do tipo $D(55 \%)$, a presença dos tipos $P_{5}(2 \%), P_{4}(15 \%), P_{3}(4 \%), P_{2}$ $(14 \%)$ e $G_{1}(7 \%)$ configura um campo de sienitos e granitos alcalinos e hiperalcalinos (Fig.VI.13). 


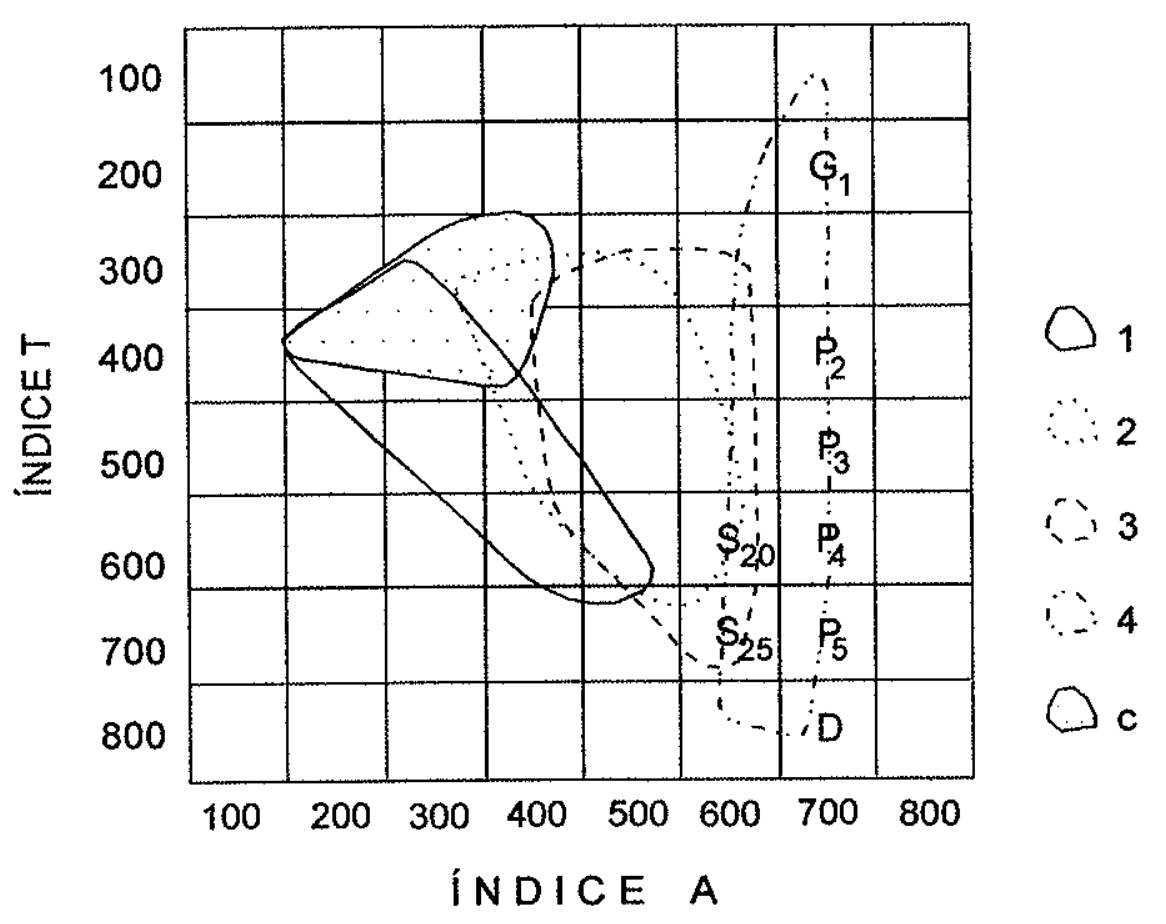

Fig.VI.13: Distribuição dos tipos morfológicos encontrados no aluvião da Lavra de Hematita no diagrama de Pupin (1980), em comparação com os campos definidos para algumas rochas plutônicas. 1: dioritos, quartzo gabros e tonalitos; 2 : granodioritos; 3: monzogranitos e monzonitos; 4: sienitos e granitos alcalinos e hiperalcalinos; c: rochas com cordierita.

Esse resultado merece atenção uma vez que, segundo a evolução geológica proposta por Schorscher (1992) para a região, entre as unidades litológicas candidatas a rocha-fonte dos zircões - rochas TTG e Granito Borrachudos (na sua forma retrabalhada - Ortognaisse Açucena) não figuram rochas alcalinas.

No entanto, a classificação obtida condiz com a interpretação dada ao Granito Borrachudos por Fernandes et al. (1994), ou seja, "granitos do tipo A alcalinos e anorogênicos originados de rochas crustais".

Estudos de tipologia do zircão desenvolvidos por I. A. Dussin (apud Dussin 1994) em rochas da Suite Borrachudos (Grossi Sad et al. 1990) revelaram o predomínio da mesma morfologia descrita acima. 


\section{PRANCHA 1}

\section{LEGENDA}

A: Aspecto macroscópico do Ortognaisse com Anfibólio e Biotita nas proximidades da Lavra de Esmeraldas de Ferros.

B: Aglomerado de minerais máficos no Ortognaisse com Anfibólio e Biotita, observando-se biotita não orientada. Luz transmitida, nicóis $\perp, 2,5 x$.

C: Microclínio micropertítico no Ortognaisse com Anfibólio e Biotita. Luz transmitida, nicóis $\perp, 2,5 x$.

D: Plagioclásio do Ortognaisse com Anfibólio e Biotita, exibindo evidências de deformação e recristalização. Luz transmitida, nicóis $\perp, 5 x$.

E: Substituição de anfibólio por biotita + quartzo + fluorita, Ortognaisse com Anfibólio e Biotita. Luz transmitida, nicóis $\perp, 20 x$. 


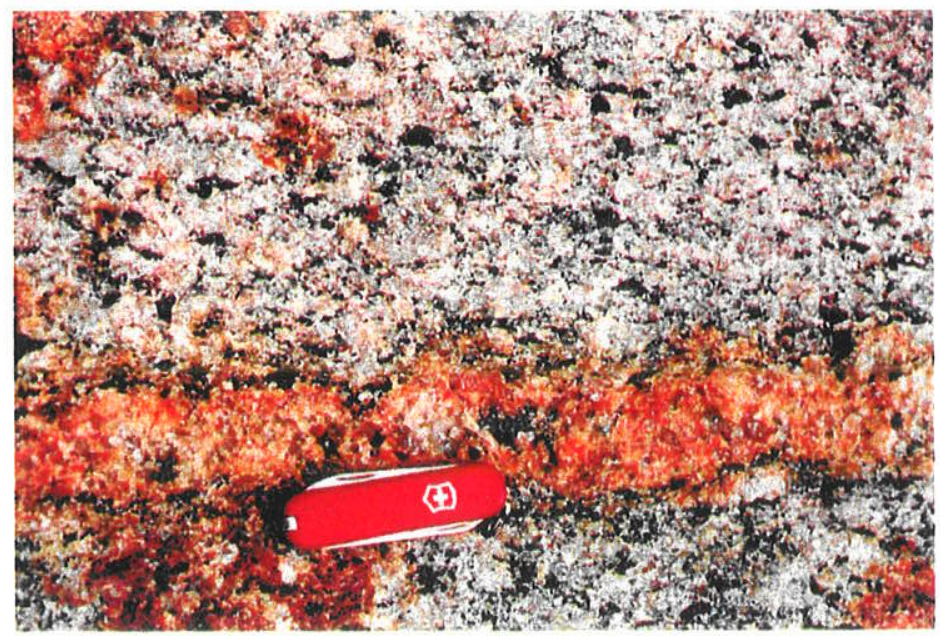

A
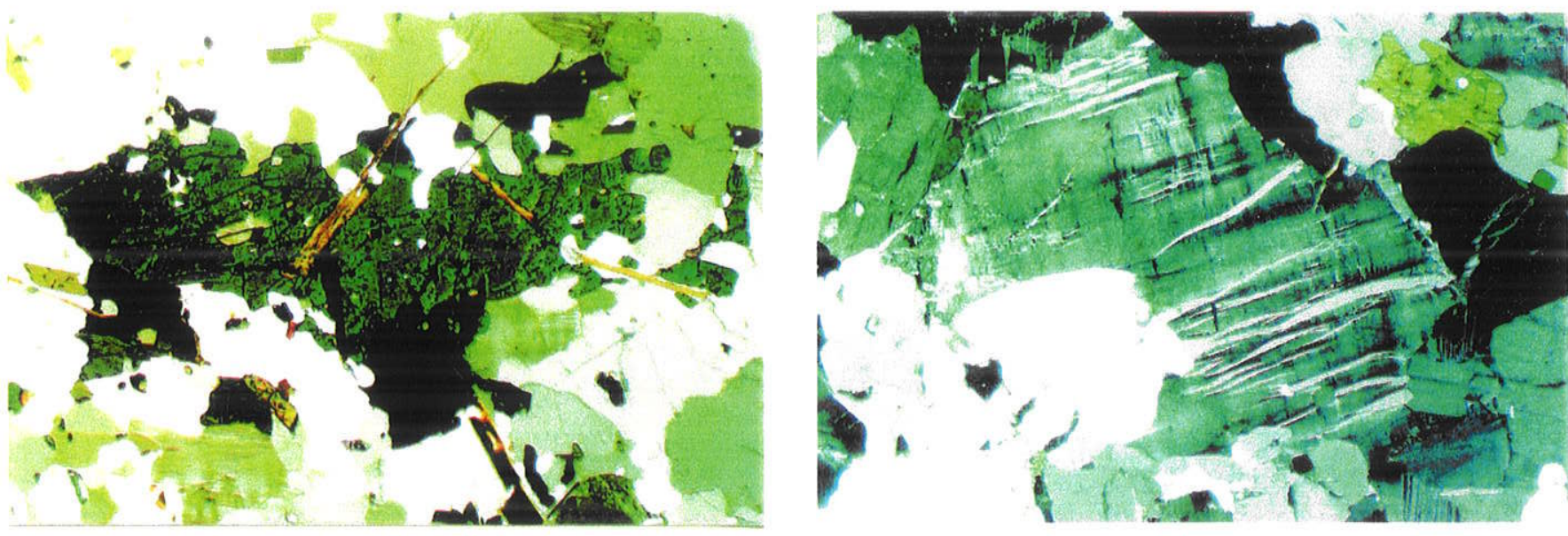

B
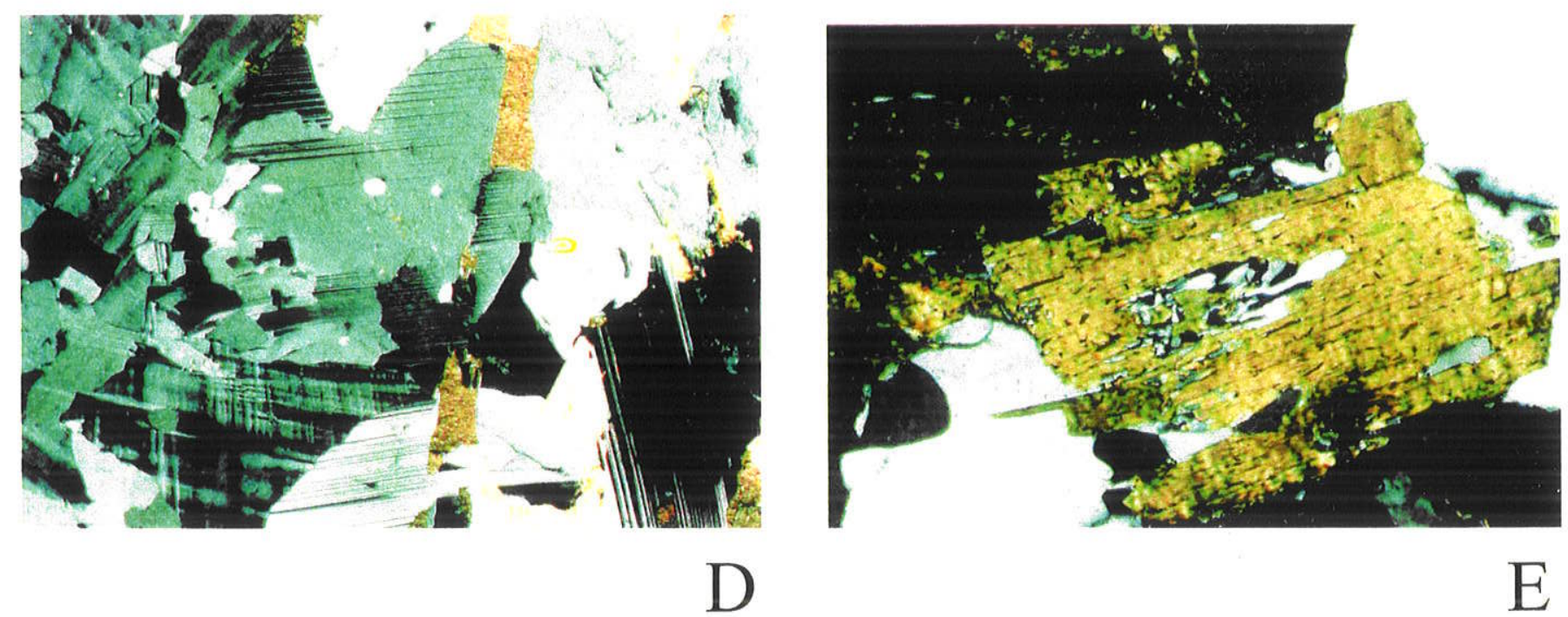


\section{PRANCHA 2}

\section{LEGENDA}

A: Antofilita tremolitito, exibindo porfiroblasto de antofilita cortando a foliação. Luz transmitida, nicóis $\perp, 5 x$.

B: Flogopitito com restos de actinolita e minerais opacos. Luz transmitida, nicóis $/ /, 2,5 x$.

C: Gnaisse Monlevade nas proximidades da ocorrência de esmeraldas de Cantagalo. 

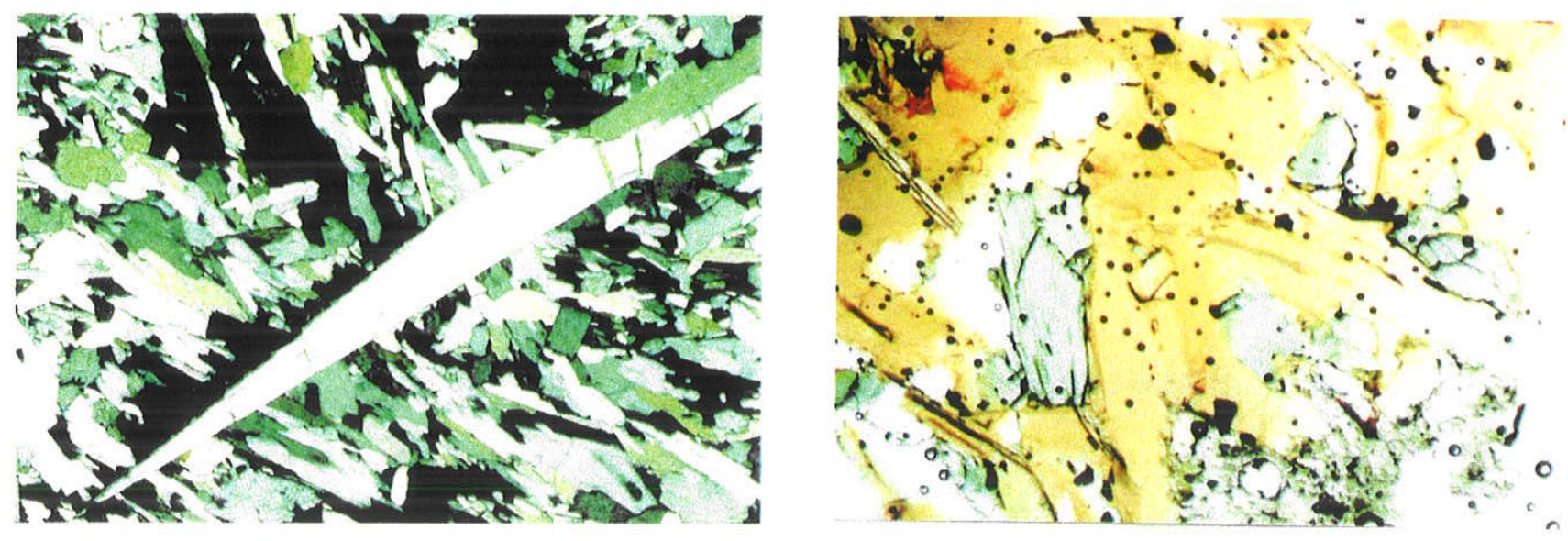

A

B

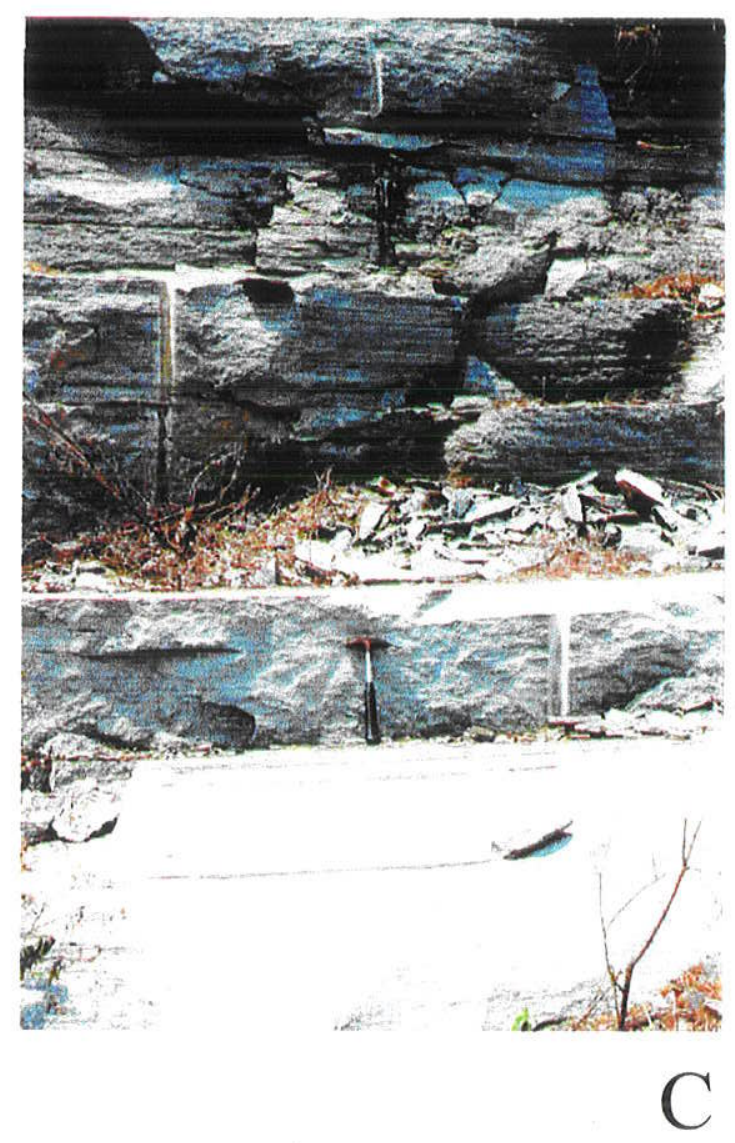




\section{PRANCHA 3}

\section{LEGENDA}

A: Gnaisse Monlevade na Lavra de Esmeraldas de Ferros, tendo ao centro o nível mineralizado em alexandrita, ambos bastante alterados.

B: Detalhe do nível mineralizado, com intercalações de níveis mais quartzofeldspáticos.

C: Nivel quartzo-feldspático eixbindo cristal de alexandrita. Escala gráfica = $1 \mathrm{~cm}$. 


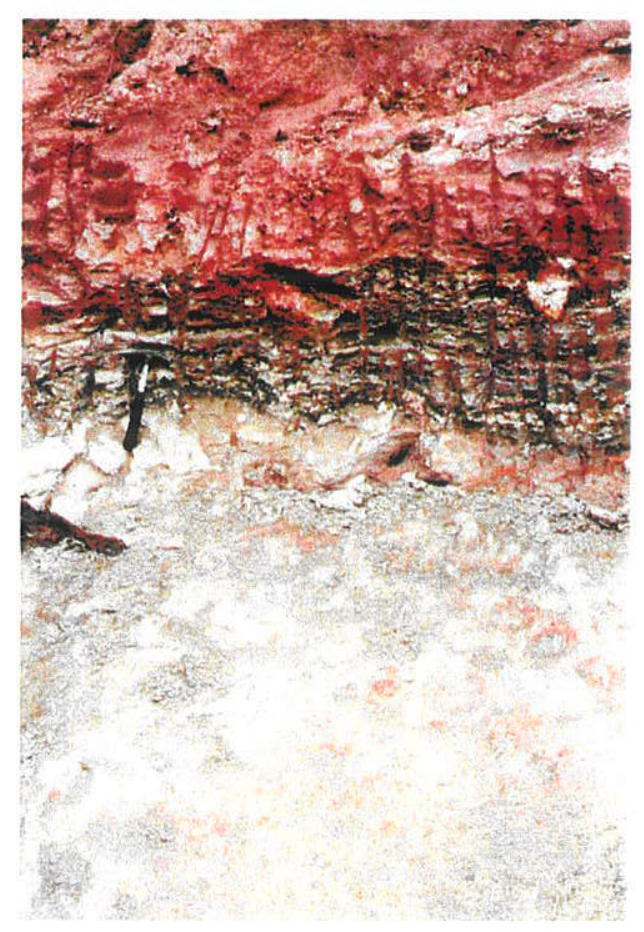

A
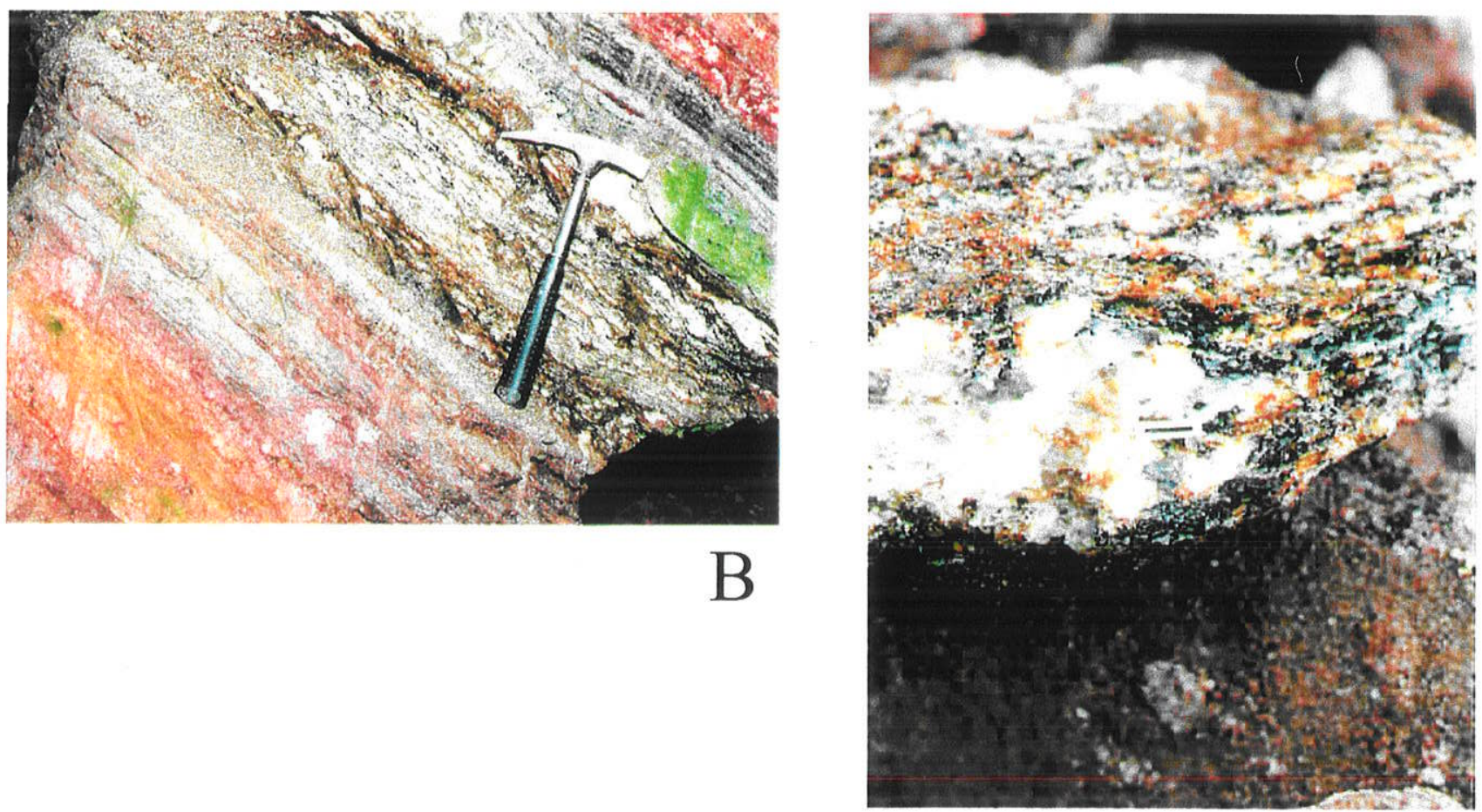


\section{PRANCHA 4}

\section{LEGENDA}

A: Conglomerado produtivo na Lavra de Hematita, constituído por seixos de quartzo em matriz areno-argilosa, sobreposto por níveis de areia e argila.

B: Exploração de alexandrita na área de Hematita, em 1986. Foto cedida pelo Sr. Nonato (Teófilo Otoni).

C: Escarpas da Serra da Liberdade, vistas da entrada da Lavra de Hematita. 

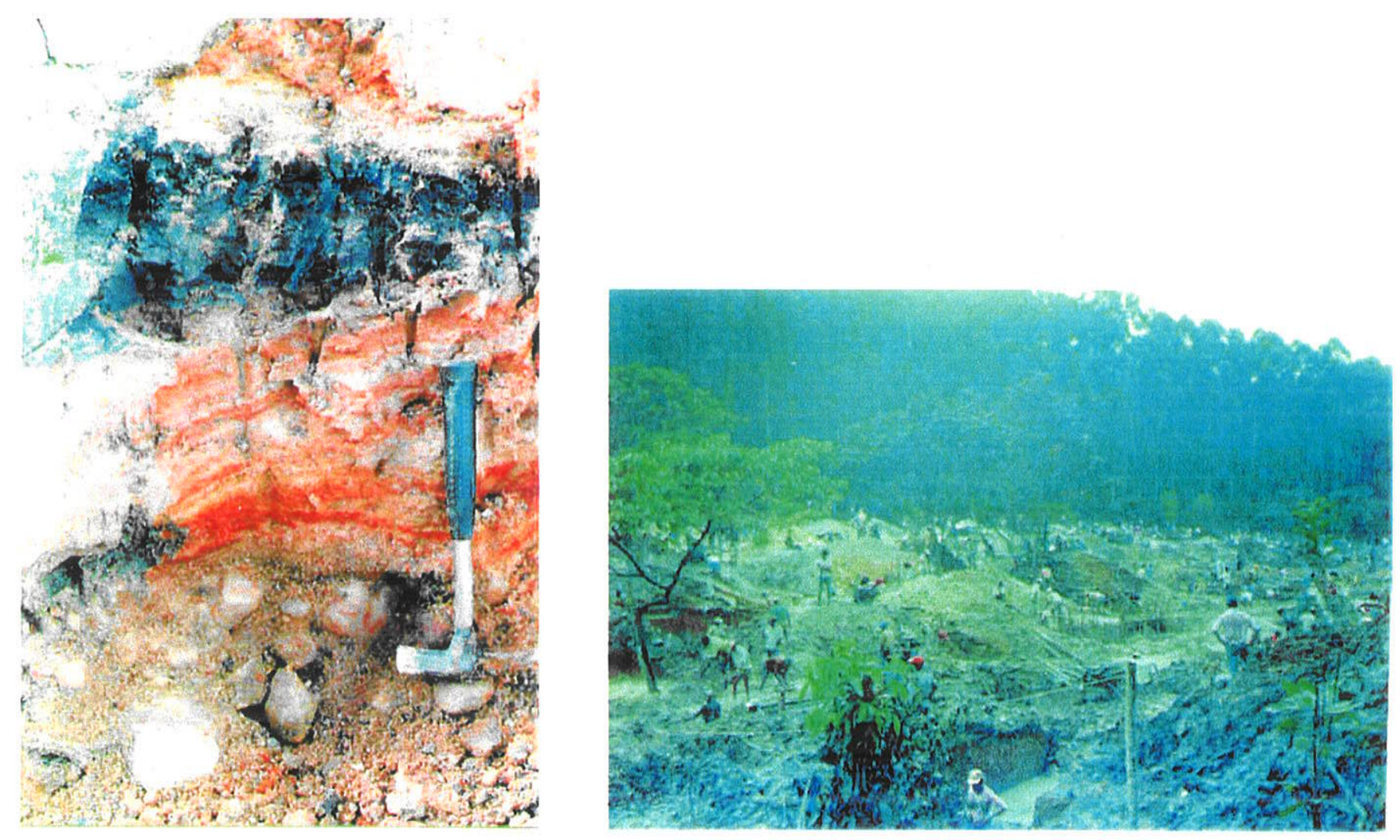

A

B

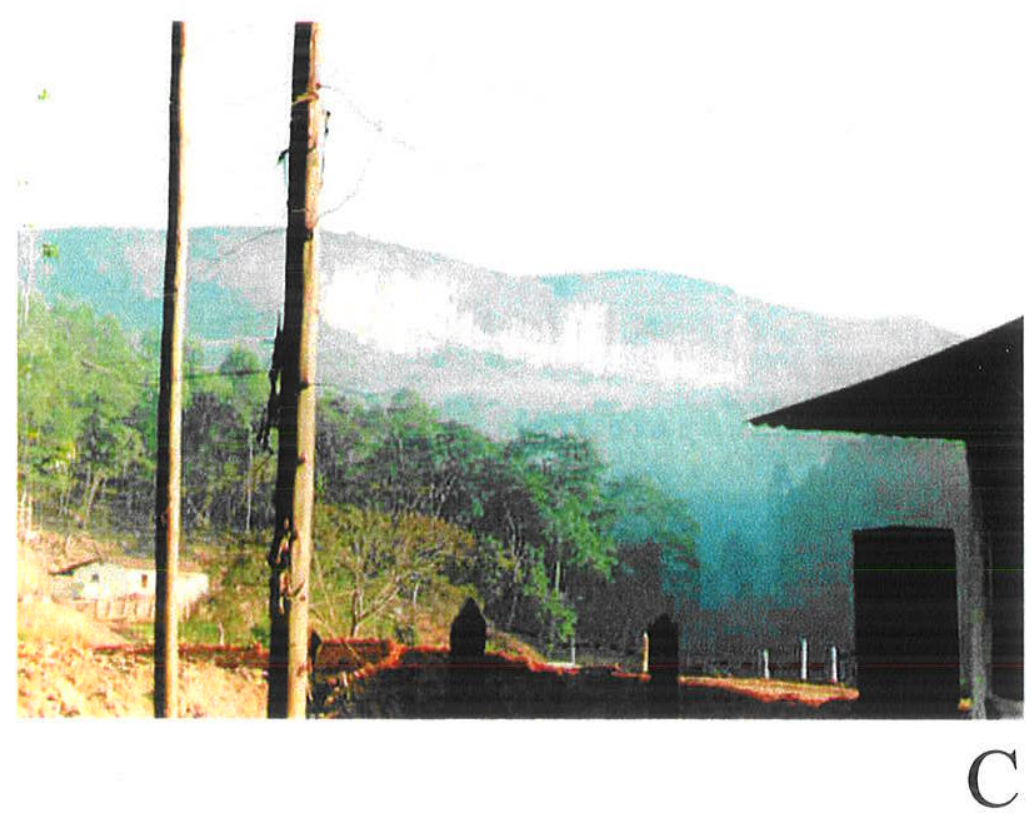




\section{MICROTERMOMETRIA DE INCLUSÕES FLUIDAS}

O objetivo dos estudos microtermométricos foi o reconhecimento dos fluidos presentes durante a mineralização berilifera $e$ as suas condições de formação.

Seções delgadas foram então preparadas a partir de 28 amostras de alexandrita (15 amostras da Lavra de Esmeraldas de Ferros e 13 da Lavra de Hematita), uma amostra de veio de quartzo do nível mineralizado de Esmeraldas de Ferros e sete amostras de esmeralda (uma amostra proveniente do aluvião da Lavra de Hematita e as demais de garimpos na rocha in situ).

VII.A. Inclusões Fluidas em Alexandrita

Apesar do grande número de seções preparadas, os 15 exemplares da Lavra de Esmeraldas de Ferros apresentaram-se livres de inclusões fluidas ou com raras inclusões secundárias.

Situação semelhante deu-se com as 13 amostras da Lavra de Hematita, tendo sido selecionadas para estudos duas seções (HM-22 e HM-26) que apresentaram inclusões fluidas de formato irregular, dispostas em trithas de origem secundária formadas em diferentes estágios de fraturamento.

Os resultados microtermométricos obtidos (Tab.VII.1 - amostras HM-22 e HM-26) revelam a presença de fluidos aquosos e aquocarbônicos de salinidade baixa a média, com quantidades variáveis mas nunca muito elevadas de $\mathrm{CO}_{2}$.

A isócora obtida para as inclusões fluidas aquocarbônicas da amostra HM26 encontra-se na figura VII. 1.

As inclusões da amostra HM-22, quando aquecidas, apresentaram grande constância na temperatura de homogeneização, a $275^{\circ} \mathrm{C}$ para a fase líquida (Fig.VII.2-A). 


\begin{tabular}{|c|c|c|c|c|c|}
\hline Amostra & 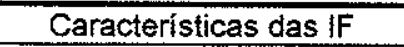 & $T_{\text {clat }}$ & $\mathrm{T}_{\mathrm{hCO} 2}$ & $\mathrm{vol} \% \mathrm{CO}_{2}$ & $T_{\text {ht }}$ \\
\hline $\begin{array}{l}\text { HM-22: alexandrita } \\
\text { IF aquocarbônicas, sem } \\
\mathrm{CO}_{2(2)} \text { visível }\end{array}$ & $\begin{array}{l}\text { IF de formato irregular, em } \\
\text { trithas }\end{array}$ & $\begin{array}{c}5,1^{\circ} \mathrm{C} \\
8,8 \% \text { eq. } \mathrm{NaCl}\end{array}$ & não visivel & 0,25 & $275^{\circ} \mathrm{C}(\mathrm{L})$ \\
\hline $\begin{array}{l}\text { HM-26: alexandrita } \\
\text { IF aquocarbônicas }\end{array}$ & $\begin{array}{l}\text { IF irregulares, em trilhas, } \\
\text { aquocarbônicas com ou } \\
\text { sem } \mathrm{CO}_{2(L)} \text { visivel; rara } \\
\text { presença de sólido } \\
\text { birrefringente }\end{array}$ & $\begin{array}{c}7,25^{\circ} \mathrm{C} \\
5,3 \% \text { eq. } \mathrm{NaCl}\end{array}$ & $\begin{array}{c}30,0 \text { a } 30,9^{\circ} \mathrm{C}(\mathrm{L} / \mathrm{C}) \\
\text { ( } 3 \text { medidas })\end{array}$ & 0,35 & \\
\hline $\begin{array}{l}\text { HM-26: alexandrita } \\
\text { IF aquosas }\end{array}$ & $\begin{array}{l}\text { IF irregulares, em trithas, } \\
\text { presença de sólido } \\
\text { birrefringente }\end{array}$ & $\begin{array}{l}T_{\text {mice: }}-5,0^{\circ} \mathrm{C} \\
8 \% \text { eq. } \mathrm{NaCl}\end{array}$ & - & $F: 0,7$ & \\
\hline $\begin{array}{l}\text { S-28: quartzo de veio } \\
\text { IF carbônicas }\end{array}$ & $\begin{array}{c}\text { IF com formato de cristal } \\
\text { negativo, em faixas }\end{array}$ & Tmco2: $-57,2^{\circ} \mathrm{C}$ & $-12,2$ a $14,8^{\circ} \mathrm{C}(\mathrm{L})$ & 1 & \\
\hline $\begin{array}{l}\text { S-28: quartzo de veio } \\
\text { IF aquosas secundárias }\end{array}$ & $\begin{array}{l}\text { IF com formato de crital } \\
\text { negativo, em trithas }\end{array}$ & $\begin{array}{l}T_{\text {mice: }}-4,5^{\circ} \mathrm{C} \\
20 \% \text { eq. } \mathrm{NaCl}\end{array}$ & & $f: 0,95$ & $165^{\circ} \mathrm{C}(\mathrm{L})$ \\
\hline $\begin{array}{c}\text { CP-7: esmeralda } \\
\text { IF tipo I: carbônicas }\end{array}$ & $\begin{array}{l}\text { ocorrem no mesmo campo } \\
\text { com IF aquocarbônicas }\end{array}$ & - & $29,5^{\circ} \mathrm{C}(\mathrm{L})$ & 1 & \\
\hline $\begin{array}{c}\text { CP-7: esmeralda } \\
\text { IF subtipo lac: } \\
\text { aquocarbônicas sem } \mathrm{H}_{2} \mathrm{O}_{(\mathfrak{L})} \\
\text { visível }\end{array}$ & $\begin{array}{l}\text { IF aquocarbônicas bifásicas } \\
\left(\mathrm{CO}_{2(L)}+\mathrm{V}\right) \text {, com presença } \\
\text { de } \mathrm{H}_{2} \mathrm{O} \text { indicada pela } \\
\text { formação de clatratos }\end{array}$ & $\begin{array}{c}\text { entre } 4,0 \text { e } 6,5^{\circ} \mathrm{C} \\
\text { entre } 6,6 \text { e } 10,5 \% \text { eq. } \mathrm{NaCl}\end{array}$ & $25,5^{\circ} \mathrm{C}(\mathrm{L})$ & película (?) & $\begin{array}{l}\text { grande espalhamento, com } \\
\text { valor médio de } 330^{\circ} \mathrm{C}(\mathrm{G})\end{array}$ \\
\hline $\begin{array}{c}\text { CP-7: esmeralda } \\
\text { IF subtipo lacL: } \\
\text { aquocarbônicas com } \mathrm{H}_{2} \mathrm{O}_{(\mathrm{L})} \\
\text { visível }\end{array}$ & $\begin{array}{c}\text { IF aquocarbônicas tri ou } \\
\text { polifásicas } \\
\left(\mathrm{CO}_{2(\mathrm{~L})}+\mathrm{H}_{2} \mathrm{O}_{(\mathrm{L})}+\mathrm{V} \pm \mathrm{S}\right)\end{array}$ & $\begin{array}{c}5,75^{\circ} \mathrm{C} \\
7,9 \% \text { eq. } \mathrm{NaCl}\end{array}$ & $27,5^{\circ} \mathrm{C}(\mathrm{L})$ & 0,78 a 0,93 & idem \\
\hline $\begin{array}{c}\text { CP-7: esmeralda } \\
\text { IF tipo H: } \\
\text { carbônicas ou } \\
\text { aquocarbônicas }\end{array}$ & $\begin{array}{l}\text { IF em trilhas, formato de } \\
\text { cristal negativo (prisma } \\
\text { achatado) }\end{array}$ & $\begin{array}{c}6,25^{\circ} \mathrm{C} \\
7 \% \text { eq. } \mathrm{NaCl}\end{array}$ & $26,5^{\circ} \mathrm{C}(\mathrm{L})$ & 0,7 & $\begin{array}{c}\text { entre } 310 \text { e } 350^{\circ} \mathrm{C}(3 \\
\text { medidas })\end{array}$ \\
\hline $\begin{array}{l}\text { HM-20: esmeralda } \\
\text { IF tipo I }\end{array}$ & $\begin{array}{l}\text { aquocarbônicas com } \mathrm{H}_{2} \mathrm{O}_{(\mathrm{L})} \\
\text { visivel, raramente sem ou } \\
\text { carbônicas }\end{array}$ & $\begin{array}{c}-2,5^{\circ} \mathrm{C} \\
18 \% \text { eq. } \mathrm{NaCl}\end{array}$ & $26,5^{\circ} \mathrm{C}(\mathrm{L})$ & 0,85 & $\begin{array}{l}\text { grande espalhamento, com } \\
\text { valores médios de } 350^{\circ} \mathrm{C} \\
\text { (G) e acima de } 560^{\circ} \mathrm{C}\end{array}$ \\
\hline $\begin{array}{l}\text { HM-20: esmeralda } \\
\text { IF tipo II }\end{array}$ & $\begin{array}{l}\text { IF aquocarbônicas com } \\
\mathrm{H}_{2} \mathrm{O}_{(\mathrm{L})} \text { visível; presença } \\
\text { constante de sólido }\end{array}$ & $\begin{array}{c}-2,5^{\circ} \mathrm{C} \\
18 \% \text { eq. } \mathrm{NaCl}\end{array}$ & $25,5^{\circ} \mathrm{C}(\mathrm{L})$ & 0,75 & 290 a $370^{\circ} \mathrm{C}$ ( 3 medidas) \\
\hline
\end{tabular}

Tab.VII.1. Resultados microtermométricos das amostras de alexandrita, esmeralda e quartzo de veio. 


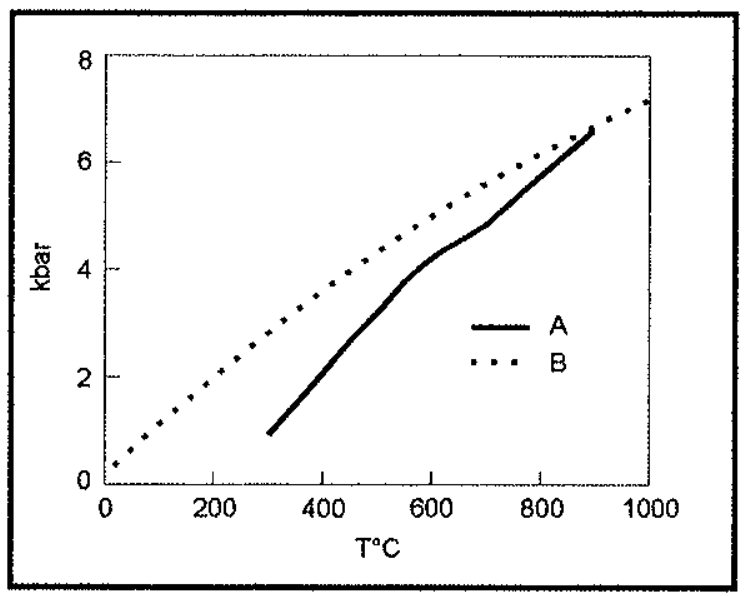

Fig.VII.1: Isócoras obtidas a partir de resultados microtermométricos em:

(A): inclusões fluidas aquocarbônicas secundárias em alexandrita, $d=0,83 \mathrm{~g} / \mathrm{cm}^{3}$. Isócora calculada com os programas Q2 e Isochor do pacote Chlatrates, versão 1997 (R. J. Bakker - Universidade de Heidelberg);

(B): inclusões fluidas carbônicas primárias em quartzo de veio, $d=1,00 \mathrm{~g} / \mathrm{cm}^{3}$. Isócora segundo diagrama PXT de Roedder (1984).

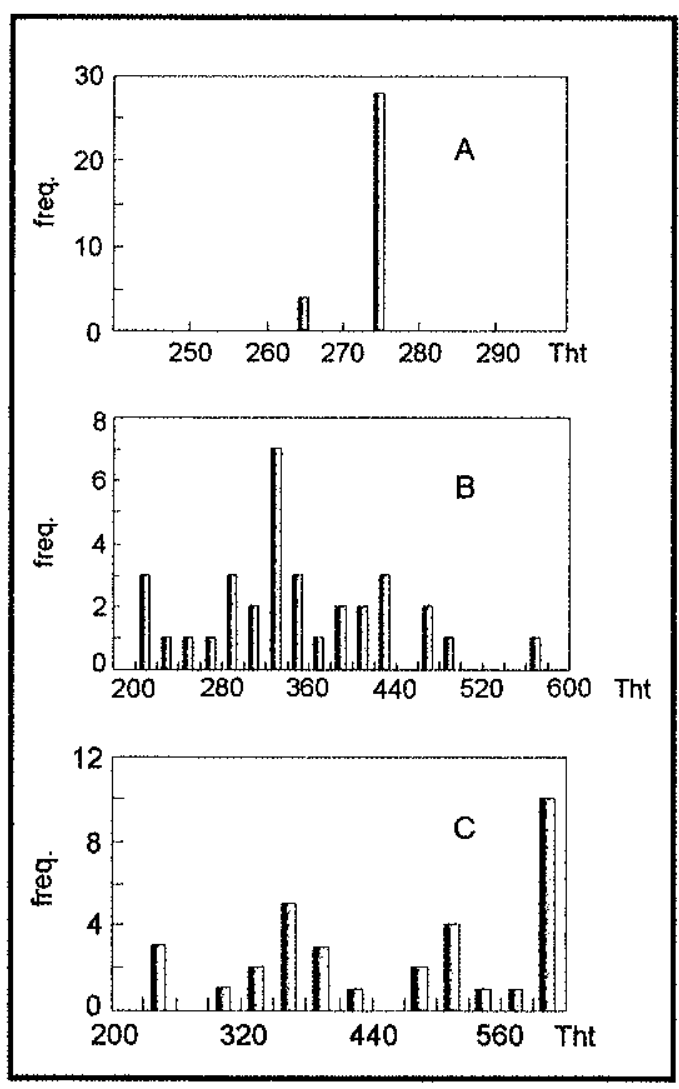

Fig.VII.2: Temperaturas de homogeneização total.

A: alexandrita (amostra HM-22) - inclusões fluidas aquocarbônicas de origem secundária;

B: esmeralda (amostra CP-7) - inclusões fluidas aquocarbônicas de tipo l;

C: esmeralda (amostra HM-20) - inclusões fluidas aquocarbônicas de tipo I. 
VII.B. Inclusões Fluidas em Veio de Quartzo do Nível Mineralizado de Esmeraldas de Ferros

O biotita xisto grafitoso da Lavra de Esmeraldas de Ferros apresenta, além dos níveis quartzo-feldspáticos mineralizados em alexandrita, também veios de quartzo concordantes com a foliação da rocha.

Nesses veios encontram-se inúmeras inclusões fluidas monofásicas com formato de cristal negativo e dimensões inferiores a $10 \mu \mathrm{m}$. A disposição dessas inclusões, alinhadas em faixas descontínuas, aproximadamente paralelas à direção do veio de quartzo hospedeiro, é sugestiva de uma origem primária a pseudosecundária, ou seja, contemporânea à formação do veio de quartzo.

Durante o resfriamento, o fluido presente nas inclusões sofreu separação em duas fases, constatando-se a presença de $\mathrm{CO}_{2}$ de densidade elevada, entre 0,83 e 1,0 ( $T_{\text {hCO2 }}$ entre $-12,2$ e 14,8 para o líquido). A presença de outros voláteis é indicada pela $\mathrm{T}_{\mathrm{mco} 2}$ inferior $\mathrm{a}-56,6^{\circ} \mathrm{C}$ (Tab.VII.1).

As inclusões fluidas de maior densidade são consideradas representativas do fluido originalmente aprisionado, devendo-se a presença de valores menores de densidade a processos posteriores de escape de fluidos. Esta hipótese encontra respaldo na elevação dos valores de $T_{\text {hco2 }}$ das inclusões carbônicas nas proximidades de trilhas de inclusões secundárias. Essas são constituídas por inclusões fluidas aquosas (Tab.VII.1) e cortam as faixas de inclusões fluidas carbônicas.

$\mathrm{Na}$ figura VII.1 encontra-se a isócora correspondente a densidade de $1,0 \mathrm{~g} / \mathrm{cm}^{3}$ segundo Roedder (1984), considerando-se a menor $\mathrm{T}_{\mathrm{hCO} 2}$ observada.

Esta é considerada representativa das condições PXT atuantes durante a formação da alexandrita, uma vez que os veios de quartzo representam provavelmente segregações sin-metamórficas, à semelhança dos veios de quartzo ricos em inclusões fluidas carbônicas descritos por Hoefs \& Morteani (1979), Kreulen (1980) e Luckscheiter \& Morteani (1980) na região dos Alpes e Grécia. 
VII.C. Inclusões Fluidas em Esmeralda

Nas amostras de esmeralda selecionadas para estudo (CP-7 e HM-20), o tipo predominante de inclusões fluidas, denominado tipo $\mathrm{I}$, corresponde àquelas inclusões com formato de cristal negativo - aciculares, tubulares ou prismáticas achatadas, de dimensões muito variadas, entre 0,002 e 0,18mm, distribuídas regularmente em determinadas regiões da amostra. Inclusões fluidas aderidas à extremidade de inclusões sólidas prismáticas fazem parte também desse tipo, porém são bem menos numerosas.

As regiões de concentração dessas inclusões de tipo I são separadas por áreas quase límpidas ou por trilhas constituídas por inclusões fluidas com formato de prisma achatado, denominadas de tipo II.

As inclusões de tipo l, embora sempre ricas em $\mathrm{CO}_{2}$, apresentam grande variabilidade na quantidade de $\mathrm{H}_{2} \mathrm{O}$, principalmente a amostra CP.7, desde inclusões carbônicas ( subtipo lc: $\mathrm{CO}_{2(L)}+V$ ), passando por aquelas onde $\mathrm{H}_{2} \mathrm{O}$ forma uma película ao redor da fase $\mathrm{CO}_{2(L)}$ e só é detectada pela formação de clatrato (subtipo lac: $\quad \mathrm{CO}_{2(L)}+V+$ sólido), até chegar a inclusões fluidas com fase $\mathrm{H}_{2} \mathrm{O}_{(L)}$ visível (subtipo lacL: $\mathrm{CO}_{2(L)}+\mathrm{H}_{2} \mathrm{O}_{(L)}+\mathrm{V}+$ sólido) (Tab.VII.1).

Embora a ocorrência do fenômeno de boiling seja sugerida pela presença lado a lado de inclusões preenchidas por esses fluidos distintos quanto ao número de fases, a ausência de inclusões ricas na fase aquosa contraria essa hipótese.

Submetidas a aquecimento, as inclusões fluidas de tipo 1 das duas amostras apresentaram homogeneizacão para a fase gasosa, porém com um grande espalhamento dos valores de $T_{h t}$ (Fig.VII.2-B,C).

VII.D. Discussão dos Resultados Microtermométricos

A existência de veios de quartzo sin-metamórficos associados à alexandrita em Esmeraldas de Ferros permitiu a construção da isócora apresentada na figura VII.1-B, que representa o regime metamórfico atuante na região durante a fase de mineralização.

No entanto, na região em estudo são reconhecidos dois estágios de mineralização berilífera: um primeiro evento, supostamente de idade arqueana, é tido 
por Machado $(1994,1998)$ como o responsável pelas ocorrências de esmeralda de Capoeirana e Belmont, a E da cidade de Nova Era, enquanto um evento de idade brasiliana teria como resultado a intrusão de pegmatitos portadores de água-marinha (Marciano et al. 1993), além de uma segunda geração de esmeraldas em Capoeirana (Machado 1994, 1998).

Embora os dados microtermométricos obtidos em alexandrita provenham todos de inclusões fluidas de origem secundária, não trazendo portanto informações diretas quanto aos fluidos responsáveis pela mineralização, alguns indícios quanto à possível idade de formação da alexandrita parecem surgir da análise desses resultados, principalmente dos aspectos morfológicos das inclusões fluidas.

Vytik \& Bodnar (1995), estudando o comportamento de inclusões fluidas sintéticas em quartzo submetidas a condições PXT de reequilíbrio diferentes da isócora inicial de formação, constataram que texturas de reequilíbrio características são desenvolvidas em função da trajetória PXT seguida pela amostra.

Embora não seja possivel uma correlação direta com os resultados dos mencionados autores devido às propriedades físicas distintas entre quartzo e alexandrita, algumas feições observadas nesta última sugerem evidências de reequilíbrio, tais como inclusões dendríticas (Prancha 5-A), em forma de arco (Prancha 5-B) ou sinais de decrepitação ou fraturamento (Prancha 5-C).

Independentemente de serem essas inclusões reequilibradas a partir de antigas inclusões primárias ou secundárias, essas feições demonstram que, após sua formação, a alexandrita passou por condições PXT que podem ser correlacionadas a um ou mais eventos metamórficos atuantes posteriormente na região.

A comparação das isócoras obtidas a partir das inclusões fluidas carbônicas em veio de quartzo com as inclusões fluidas secundárias em alexandrita confirma o aprisionamento de fluidos ao longo de duas trajetórias PXT distintas, novamente representando provavelmente dois regimes metamórficos distintos.

Dando continuidade a seus estudos de reequilíbrio com inclusões fluidas sintéticas em quartzo, Vytik \& Bodnar (1998) constataram que a dispersão nos valores de densidade do fluido (consequentemente $T_{h t}$ ) é tanto mais notável quanto maior for o afastamento das condições da isócora inicial de formação. 
A dispersão quase nula dos valores de $T_{\text {ht }}$ observada nas inclusões fluidas secundárias da amostra HM-22 (Fig.VII.2-A) sugere portanto tratar-se de amostras que não sofreram reequilibrios posteriores. Considerando-se o contexto geológico regional, essas inclusões fluidas poderiam ter sido aprisionadas durante o evento Brasiliano, o último evento tectono-metamórfico a afetar a região $E$ e $N E$ do Quadrilátero Ferrifero com intensidade de fácies xisto verde, localmente alcançando fácies anfibolito (Teixeira et al. 1990, Alkmin \& Marshak 1998).

Quanto às inclusões fluidas nas esmeraldas estudadas, é provável que os fluidos originais também não se encontrem preservados nem mesmo nas inclusões de tipo I, inicialmente consideradas primárias com base apenas em sua morfologia.

A grande dispersão dos valores de temperaturas de homogeneização total (Fig.VIl.2-B,C) sugere, segundo os já mencionados experimentos de Vytik \& Bodnar (1998), novamente reequilíbrio frente a condições PXT fora da isócora inicial de formação das inclusões fluidas.

No entanto, feições texturais de reequilíbrio não foram observadas nas esmeraldas, sugerindo que outros processos podem ter atuado no caso desse mineral. Além dos processos descritos por Vytik \& Bodnar (1995), que resultam em mudança de volume, a perda preferencial de $\mathrm{H}_{2} \mathrm{O}$ em fluidos aprisionados em quartzo também tem sido apontada por vários autores como causadora de mudanças composicionais nos fluidos primários (Hollister 1990, Bakker \& Jansen 1991, 1994, Hall \& Sterner 1993, Cordier et al. 1994). Enquanto no quartzo esse escape de $\mathrm{H}_{2} \mathrm{O}$ tem sido atribuído à presença de deslocamentos (dislocations), na esmeralda a presença de canalículos estruturais deve favorecer ainda mais o processo, ou mesmo ser o fator de maior influência. 


\section{PRANCHA 5}

\section{LEGENDA}

A: Alexandrita de Esmeraldas de Ferros, exibindo um arranjo dendrítico de minúsculas inclusões fluidas secundárias ao redor da inclusão primária. Luz transmitida, nicóis $/ /, 50 \mathrm{x}$.

B: Alexandrita de Hematita, exibindo inclusões fluidas em forma de arco. Luz transmitida, nicóis $/ /, 20 x$.

C: Alexandrita de Esmeraldas de Ferros, tendo ao centro trilha de inclusões fluidas com evidências de decrepitação (setas). Luz transmitida, nicóis //, 20x. 


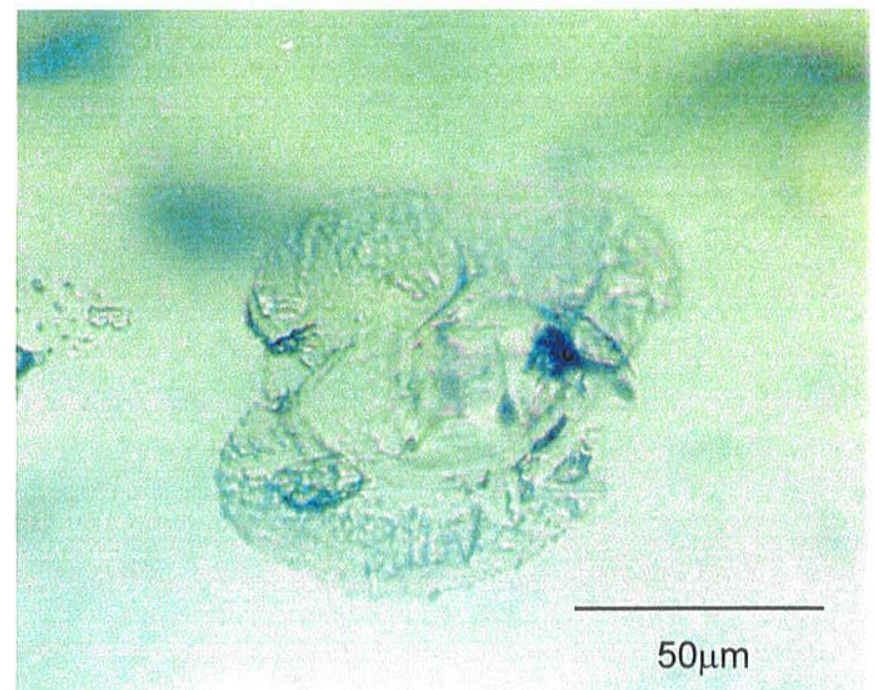

A
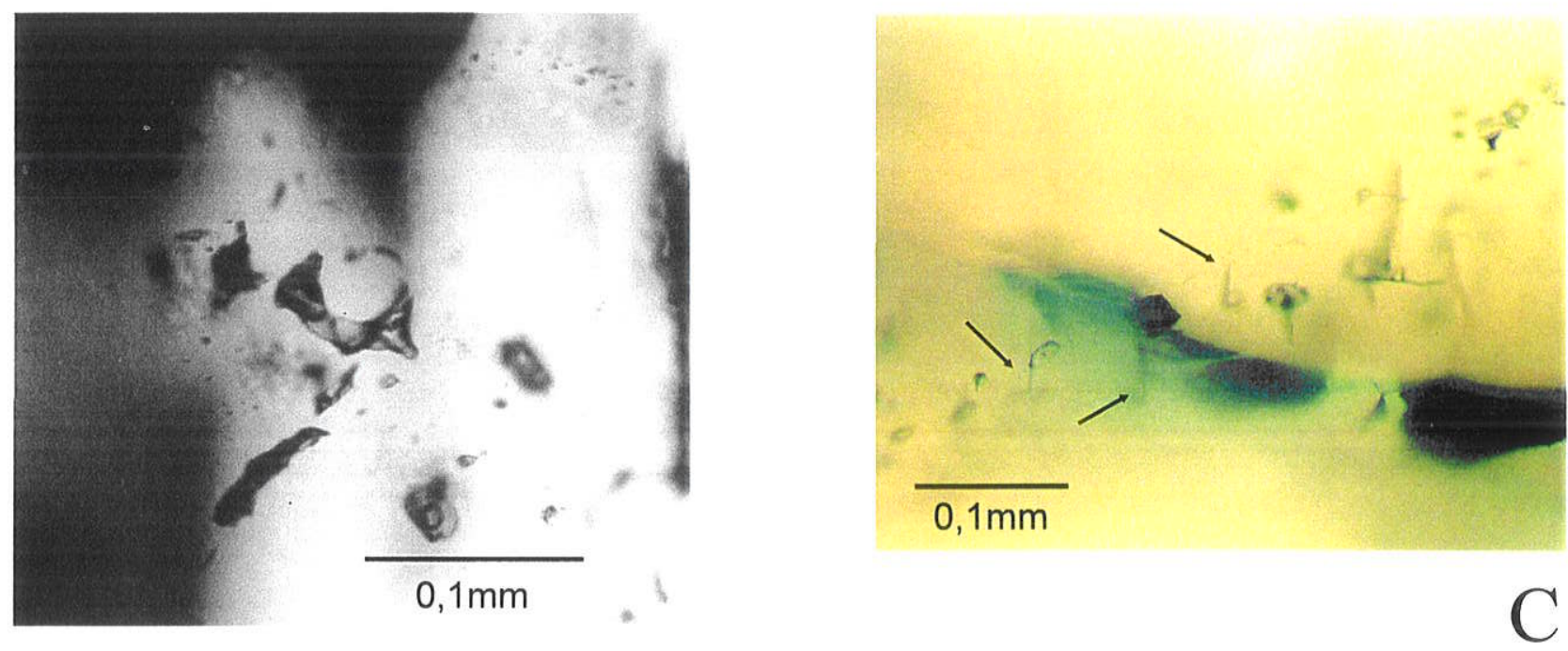

B 


\title{
VIII. ISÓTOPOS ESTÁVEIS DE CARBONO
}

\author{
VIII.A. Princípios do Método
}

Os fundamentos da geoquímica de isótopos estáveis e principais aplicações podem ser encontrados em Emery \& Robinson (1993) e Hoefs (1997), dentre outros.

A geoquímica de isótopos estáveis utiliza-se dos elementos leves $\mathrm{H}, \mathrm{C}, \mathrm{N}$, $O$ e $S$, e pode fornecer tanto informações sobre a origem (fonte) de um elemento como também sobre a temperatura de formação de um fluido ou mineral.

Pelo fato de as propriedades termodinâmicas e físicas dos isótopos de um determinado elemento serem ligeiramente diferentes, aqueles são separados, ou fracionados, quando as substâncias que os contém participam de reações químicas ou sofrem mudanças de estado.

Esse fracionamento isotópico ocorre porque a força das ligações químicas varia ligeiramente com a massa do isótopo, sendo geralmente menor no isótopo mais leve. Três tipos de fracionamento podem ocorrer em sistemas naturais:

1. efeito cinético (kinetic isotope effect): isótopos leves reagem mais rapidamente que os isótopos pesados; importante em reações unidirecionais que não se completam, por exemplo redução de sulfatos por bactérias;

2. efeito de equilíbrio isotópico (equilibrium isotope effect) ou fracionamento de equilíbrio isotópico: ocorre porque quando uma reação atinge o equilibrio, os isótopos são distribuídos entre os compostos de modo a minimizar a energia livre do sistema em questão;

3. efeito vital ou biológico (vital or biological isotope effect): observado em certos organismos que produzem esqueletos minerais que estão em desequilíbrio isotópico com a água ao redor.

A terminologia adotada correntemente inclui:

. $\delta$ : desvio, em partes por mil (\%o), da razão isotópica de uma amostra $A$ em relação à razão isotópica de um padrão aceito internacionalmente, ou seja 
$\delta_{A}=\left[\left(R_{A}-R_{\text {padrăo }}\right) / R_{\text {padrão }]} * 10^{3}\right.$, onde $R=$ isótopo pesado/isótopo leve

$\alpha$ : fator de fracionamento isotópico entre as fases $A$ e $B$, ou seja

$$
\alpha_{A-B}=R_{A} / R_{B}
$$

ou, a partir dos valores de $\delta$

$\alpha_{A-B}=\left(1000+\delta_{A}\right) /\left(1000+\delta_{B}\right)$, mais comumente $\delta_{A}-\delta_{B} \approx 10^{3} \ln \alpha_{A-B}$

O carbono possui dois isótopos, ${ }^{12} \mathrm{C}$ e ${ }^{13} \mathrm{C}$, com abundâncias de 98,89 e $1,11 \%$, respectivamente (Hoefs 1997).

Os principais reservatórios terrestres de $\mathrm{C}$ - matéria orgânica e carbonatos de origem sedimentar - apresentam composições isotópicas bem distintas (Ohmoto \& Rye 1979): $\delta^{13} \mathrm{C}$ nos compostos orgânicos varia entre $-10 \mathrm{e}$ $35 \%$, com média de $-25 \%$; carbonatos marinhos apresentam $\delta^{13} \mathrm{C} \approx 0 \pm 4 \%$, enquanto $\delta^{13} \mathrm{C}$ nos carbonatos de água doce varia entre -2 e $-10 \%$.

\section{VIII.B. Resultados Obtidos}

A presença de inclusōes fluidas carbônicas em veio de quartzo associado à grafita permitiria, a princípio, considerações quanto à origem do fluido contemporâneo à mineralização de alexandrita em Esmeraldas de Ferros. Admitindose a coexistência em equilíbrio entre grafita e $\mathrm{CO}_{2}$, poder-se-ia ainda estimar uma temperatura a partir do fator de fracionamento ( $\alpha_{\mathrm{CO} 2}$ - grafita) utilizando-se os resultados de Bottinga (1969).

A grafita separada a partir do biotita xisto grafitoso mineralizado forneceu $\delta^{13} \mathrm{C}=-19,9 \%$, valor condizente com uma origem a partir de sedimento rico em matéria orgânica.

$O$ valor obtido para as inclusões fluidas carbônicas, $\delta^{13} \mathrm{C}=-4,3 \%$, pode ser considerado indicativo da origem do $\mathrm{CO}_{2}$ a partir da hidrólise da matéria orgânica (Ohmoto \& Rye 1979): 


$$
2 \mathrm{C}+2 \mathrm{H}_{2} \mathrm{O}=\mathrm{CO}_{2}+\mathrm{CH}_{4}
$$

Nesse processo, mais importante a temperaturas elevadas do que a oxidação de $\mathrm{C}$, pode ocorrer enriquecimento $\mathrm{em}{ }^{13} \mathrm{C}$ de até $12 \%$ no fluido resultante em relação à matéria orgânica original. A oxidação, processo predominante em condições mais superficiais, resultaria em valores de $\delta^{13} \mathrm{C}$ semelhantes aos da matéria orgânica (Ohmoto \& Rye 1979).

Partindo-se do pressuposto de que grafita e $\mathrm{CO}_{2}$ formaram-se em equilíbrio, o fator de fracionamento isotópico pode ser calculado e utilizado para a determịnação de um valor de temperatura (Bottinga 1969). O valor de $\alpha_{\mathrm{CO} 2}$ - grafita $=$ 1,0159 , quando confrontado com os dados tabelados pelo autor, fornece temperatura ao redor de $100^{\circ} \mathrm{C}$, um resultado incoerente com o contexto regional em que se insere o biotita xisto grafitoso.

Uma explicação para essa discrepância seria admitir que os valores de $\delta^{13} \mathrm{C}$ apresentados pela grafita e pelo fluido carbônico não representam condições de equilíbrio, considerando-se a origem do fluido carbônico, e conseqüentemente de sua razão isotópica, a partir de $\mathrm{CO}_{2}$ derivado da hidrólise da matéria orgânica, como admitido acima, acrescido de $\mathrm{CO}_{2}$ resultante de reações de descarbonatação.

De fato, considerando-se apenas o máximo enriquecimento em ${ }^{13} \mathrm{C}$ promovido pelo processo de hidrólise, $+12 \%$ conforme relatado por Ohmoto \& Rye (1979), ter-se-ia um fluido carbônico ainda muito leve $\left(\delta^{13} \mathrm{C}=-7,9 \%\right)$ em comparação com o valor obtido $\left(-4,3 \%\right.$ ) , exigindo portanto a contribuição de $\mathrm{CO}_{2}$ mais pesado proveniente de sedimentos carbonáticos.

Alguns autores, investigando inclusões fluidas carbônicas em veios de quartzo na região dos Alpes, obtiveram razões isotópicas semelhantes ao valor apresentado neste trabalho. Hoefs \& Stalder (1977) e Hoefs \& Morteani (1979) encontraram intervalos de $\delta^{13} \mathrm{C}$ respectivamente de $-2,0$ a $-9,6 \%$ e $-1,5$ a $-7,0 \%$, que interpretaram também como indicativos de uma origem a partir da mistura entre processos de descarbonatação e oxidação de matéria orgânica em proporções variáveis. 


\section{CARACTERIZAÇÃO MINERALÓGICA DO CRISOBERILO}

Neste item, além da identificação de propriedades físicas, tais como cor, hábito, brilho, densidade, etc., foram investigadas com maior detalhe certas características normalmente tratadas apenas qualitativamente, como comportamento em radiação infravermelha, catodoluminescência ou ainda o efeito do fenômeno de chatoyancy sobre as constantes cristalográficas do crisoberilo.

As análises concentraram-se em sua maioria em amostras de alexandrita de Esmeraldas de Ferros e Hematita, ocasionalmente incluindo também amostras da ocorrência de Quilombo ou ainda amostras de procedência incerta, apenas para efeito de comparação.

\section{IX.A. Propriedades físicas}

\section{IX.A.1. Lavra de Esmeraldas de Ferros}

$\mathrm{Na}$ Lavra de Esmeraldas de Ferros, a única variedade de crisoberilo encontrada até o momento foi a alexandrita.

São cristais e fragmentos de cristais pequenos, raramente ultrapassando $5 \mathrm{~mm}$, em alguns casos exibindo faces de crescimento que permitem o reconhecimento de hábito tabular ou da geminação cíclica típica do crisoberilo, neste último caso simulando prismas hexagonais (Prancha 6-A).

As cores variam entre verde e azul-acinzentado, com mudança de cor (efeito alexandrita) em intensidades variáveis, desde ausente até forte (vermelho vinho). Aplicando-se a classificação de cores do sistema de Munsell ( $H$ V/C), em luz branca predominam os matizes azul-esverdeado (BG) e verde $(G)$, escuros $(V=2-4)$, de saturação média $(C=4)$. Em luz amarela, ocorre predominância dos matizes vermelho-púrpura (RP), escuros $(V=2-4)$ a medianamente escuros $(V=5-7)$, de saturação baixa $(C=1-3)$ a média $(C=4-6)$ (total de 24 medidas).

Os valores para o índice de refração, obtidos em refratômetro gemológico (quatro amostras), situaram-se entre 1,745 e 1,757, portanto dentro dos limites apresentados por Trögger (1979) para $n_{x}$ e $n_{z}$, respectivamente 1,744-1,747 e 1,753- 
1,758. O pleocroísmo, observado em microscopia de luz transmitida, é intenso: $x=$ vermelho-vinho; $y=$ amarelo; $e z=$ azul-esverdeado.

A transparência é pequena, o brilho vítreo a resinoso e o efeito olho-degato está presente em todos os exemplares, o que constitui, até o momento, a feição mais típica desta ocorrência.

A densidade relativa, medida em seis grãos, variou entre 3,70 e 3,79, com um valor médio de 3,74 .

\section{IX.A.2. Lavra de Hematita}

$\mathrm{Na}$ Lavra de Hematita, a variedade predominante é a alexandrita, com a presença ocasional de crisoberilo amarelo-esverdeado e olho-de-gato. No entanto, devido ao preço elevado da alexandita de Hematita, os exemplares fornecidos para análise apenas em parte representam o material de valor gemológico disponivel no mercado.

Não foi reconhecido o hábito pelo fato de tratar-se apenas de fragmentos pouco arredondados, com dimensões variando entre 4 e $9 \mathrm{~mm}$, de cores verdeazulado, verde-amarelado ou verde-escuro (Prancha 6-B). A intensidade do efeito alexandrita está relacionada à intensidade da cor do material em luz branca, ou seja, cristais verde-escuro tornam-se vermelho-escuro a vinho, enquanto aqueles mais claros, verde-amarelado, quase não se alteram, ou mostram tons claros, levemente arroxeados.

Utilizando-se a classificação de Munsell, em luz branca predominam matizes verdes $(G)$, escuros $(V=2-4)$ e medianamente saturados $(C=4-6)$. Em luz incandescente têm-se matizes vermelho-púrpura (RP), medianamente escuros $(V=5$ 7 ), com saturação média ( $C=4-6)$ (nove amostras).

A variação do índice de refração, 1,745 a 1,758 (três amostras), novamente manteve-se dentro dos limites apresentados na tabela I.1.

A transparência do material é geralmente elevada, o brilho é vitreo e o efeito olho-de-gato, quando ocorre, restringe-se a faixas bem definidas dentro de cada cristal (Prancha 6-C). 
Cristais examinados em microscopia de luz transmitida revelaram pelocroísmo intenso, variando entre vermelho a roxo $\rightarrow$ amarelo-esverdeado $\rightarrow$ azulesverdeado.

A densidade relativa, medida em cinco amostras, variou entre 3,62 e 3,75, com média de 3,69 .

\section{IX.A.3. Ocorrência de Quilombo}

Na ocorrência de Quilombo, o crisoberilo amarelo predomina sobre a variedade mais rara, a alexandrita.

Da variedade comum do crisoberilo foram descritas oito amostras, entre fragmentos de cristais tabulares e geminados, com dimensões variando de 0,7 a $1,7 \mathrm{~cm}$ e cores amarela, verde-amarelado e verde-claro. Aplicando-se a classificação de Munsell, verifica-se o predomínio de matizes verde-amarelado (GY) e verde (G), claros $(V=7-9)$ e medianamente saturados $(C=4-6)$.

As superfícies dos cristais são geralmente foscas, reconhecendo-se o brilho vítreo apenas em pequenas superfícies de clivagem. Alguns exemplares apresentam efeito olho-de-gato.

A densidade relativa, determinada para quatro amostras, situou-se entre 3,67 e 3,69, com valor médio de 3,68.

As cinco amostras de alexandrita apresentam-se como cristais em geminação cíclica, com dimensões variando entre 1,0 e $2,2 \mathrm{~cm}$.

As cores em luz branca são muito variadas - verde-escuro, verdeamarelado, verde-acinzentado claro - assim como as cores em luz incandescente rosa, salmão, ferrugem, vinho. No sistema de Munsell predominam, em luz branca, matizes verde-amarelado $(G Y)$ e verde $(G)$, medianamente escuros $(V=5-7)$, com saturação baixa $(C=1-3)$ a média $(C=4-6)$. Em luz incandescente, destaca-se o matiz vermelho (R), medianamente escuro $(V=4-6)$, com alta saturação $(C=7-10)$.

O material apresenta-se quase opaco, com as superficies foscas e muito fraturado, sugerindo algum transporte.

A densidade foi determinada para quatro amostras, fornecendo valores entre 3,60 e 3,70, com média de 3,67. 


\section{IX.B. Feições Internas}

$\mathrm{Na}$ literatura gemológica, são consideradas inclusões todas as irregularidades observadas opticamente no interior de um mineral (Gübelin 1974 apud Schwarz 1987), ou seja, feições como fraturas, zoneamentos, planos de geminação, clivagem ou partição são também descritas como inclusões.

Neste item segue-se uma divisão informal das feições internas observadas no crisoberilo de Esmeraldas de Ferros e Hematita, agrupando-se sob o termo inclusões apenas inclusões sólidas e fluidas.

IX.B.1. Zoneamentos, fraturas, exsoluções

O zoneamento de cor é um fenômeno de crescimento associado a mudanças periódicas no meio a partir do qual precipita-se o mineral (Schwarz 1987).

Tanto nas amostras provenientes de Esmeraldas de Ferros quanto de Hematita foi constatado zoneamento de cor na forma de estriações retas ou angulares, correspondendo a variações muito sutis visíveis apenas ao microscópio petrográfico.

Um outro tipo de zoneamento, mais comum na alexandrita de Esmeraldas de Ferros, caracteriza-se por regiōes de coloração castanho-avermelhada às quais associam-se minúsculas inclusões aciculares orientadas paralelamente ao eixo $\underline{\mathrm{c}}$ do mineral, responsáveis pelo efeito olho-de-gato (Prancha 6-D). A essas regiões correspondem também diferenças na composição química, com teores mais elevados em $\mathrm{TiO}_{2}$ (item IX.C).

O tamanho diminuto dessas inclusões constitui-se num empecilho à sua identificação por meio de microscopia óptica, ao passo que a observação de amostras ao microscópio eletrônico de varredura não apresentou nenhum resultado.

No entanto, Marder \& Mitchell (1982), utilizando-se de técnicas analíticas mais sofisticadas (microscopia eletrônica de transmissão, microdifratometria e electron energy loss spectrometry - EELS), identificaram tais inclusões como exsoluções de rutilo orientadas segundo [100] e [110] no plano (001), o que condiz com a elevação nos teores de $\mathrm{TiO}_{2}$ constatada nas análises químicas por microssonda eletrônica (item IX.C.). 
A presença de fraturas também é comum na alexandrita de ambas as ocorrências, normalmente com preenchimento por limonita.

\section{IX.B.2. Inclusões sólidas e fluidas}

A maior variedade e quantidade de inclusões sólidas foram observadas nas amostras da Lavra de Esmeraldas de Ferros, principalmente minerais opacos: ilmenita, pirita, calcopirita, pentlandita e grafita. O mineral transparente mais freqüente é o quartzo.

- grafita: aderida à superfície dos cristais de alexandrita ou como inclusões, podendo apresentar-se corroída (Prancha 6-E,F). O espectro de EDS confirma a identificação por microscopia de luz refletida.

- ilmenita: dentre os opacos, é a inclusão mais comum, ocorrendo como grãos de bordas arredondadas, alguns tendendo a placóides (Prancha 6-G).

. sulfetos: em associações de pirita, calcopirita e pentlandita (Prancha 6-H) ou em grãos isolados, arredondados e anedrais.

. quartzo: muito comum, na forma de grãos euédricos geralmente em grupos de vários cristais (Prancha 7-A,B).

- augita: observada raramente, como cristais prismáticos (Prancha 7-C) de birrefringência elevada, extinção oblíqua e índice de refração superior ao da alexandrita hospedeira. O espectro de EDS, confirmando a composição de piroxênio cálcico, encontra-se na figura Prancha 7-D.

Quanto à alexandrita da Lavra de Hematita, as inclusões sólidas observadas foram bem pouco numerosas, tanto em volume quanto variedade:

- titanomagnetita: um grão semi-incluso, isométrico, isotrópo, identificado como titanomagnetita a partir de suas propriedades ópticas e composição química determinada por EDS (Prancha 7-G).

. quartzo: ao contrário do observado nas alexandritas de Esmeraldas de Ferros, aqui o quartzo ocorre como raros grãos isolados (Prancha 7-E,F), cuja composição química foi confirmada por EDS. 
. anfibólio: observado apenas um gräo de hábito prismático (Prancha 7-H).

Ao conjunto de inclusões sólidas identificadas neste trabalho acrescentam-se ainda aquelas descritas por Bank et al. (1987) em Hematita apatita, fluorita e calcita - e Karfunkel \& Wegner (1993) em Esmeraldas de Ferros mica e minerais de hábito acicular.

As inclusões fluidas presentes nas alexandritas de Esmeraldas de Ferros e Hematita são de natureza secundária, ou seja, alinhadas em planos de antigas fraturas cicatrizadas formadas posteriormente à cristalização do mineral hospedeiro (Roedder 1984).

A morfologia das inclusões é bastante variada, desde formato de cristal negativo até inclusões dendríticas, revelando estágios diversos de cicatrização das fraturas.

Principalmente nas inclusões com formato de cristal negativo, nota-se atualmente o preenchimento das cavidades por agregados de sólidos birrefringentes (Prancha 8-A,B), possivelmente sericita ou outro mineral secundário.

\section{IX.C. Composição Química, Efeito Alexandrita e Catodoluminescência}

A composição química de alexandritas de Esmeraldas de Ferros e Hematita foi determinada por microssonda eletrônica, encontrando-se os resultados nas tabelas IX.1 e IX.2.

Apesar dos problemas analíticos decorrentes da impossibilidade da dosagem de $\mathrm{BeO}$, a técnica foi utilizada pela oportunidade que oferece no estudo de zoneamentos dentro de grãos, permitindo a análise de variações nos fenômenos de mudança de cor e catodoluminescência em função da composição química.

\section{IX.C.1. Composição química}

Analisando-se os dados apresentados nas tabelas IX.1 e IX.2, constata-se que os elementos traço de maior relevância são $\mathrm{Cr}, \mathrm{Fe}$ e $\mathrm{Ti}$, provavelmente substituindo Al em posições octaédricas na estrutura do mineral, sendo os teores em outros elementos geralmente muito baixos. 


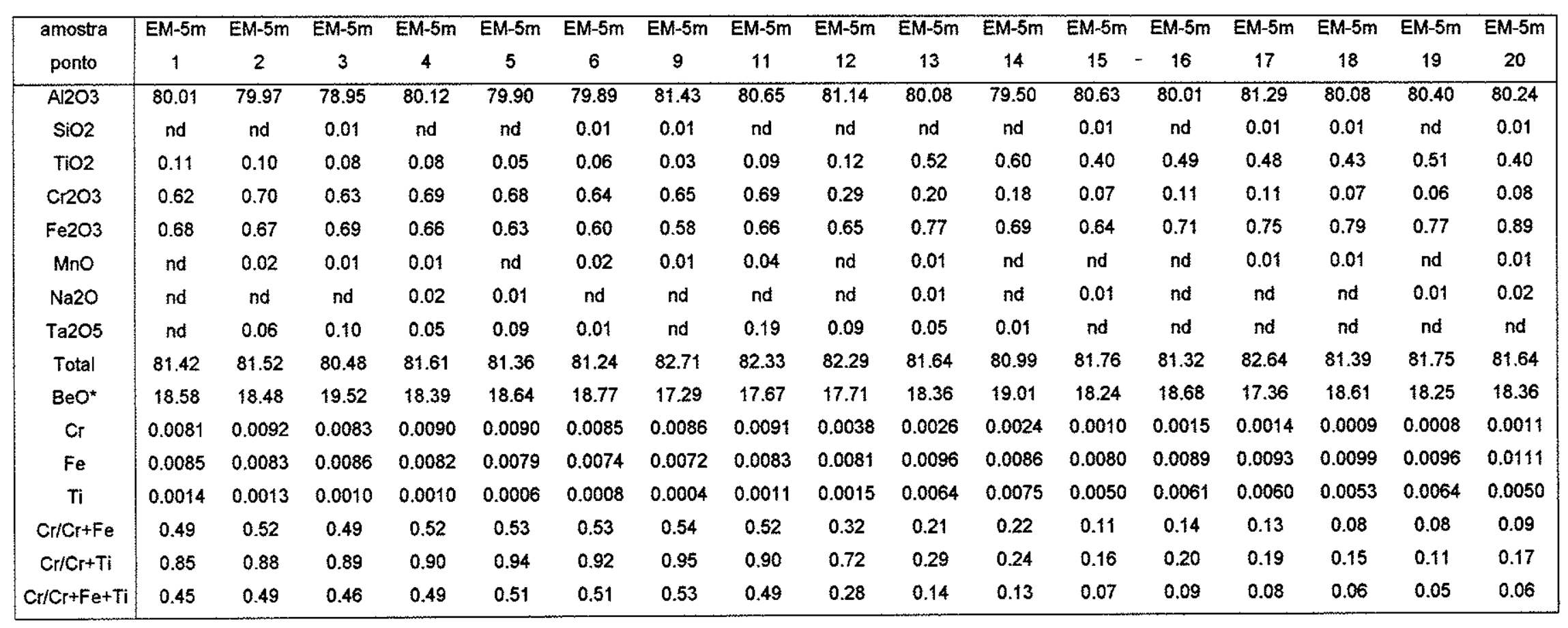

Tab.IX.1: Composições químicas de crisoberilos de Esmeraldas de Ferros (EM) e Hematita (HM) obtidas por microssonda eletrônica. $\mathrm{Cr}$, Fe e Ti: proporções atômicas; *: por diferença. 


\begin{tabular}{|c|c|c|c|c|c|c|c|c|c|c|c|c|c|c|}
\hline $\begin{array}{c}\text { amostra } \\
\text { ponto }\end{array}$ & $\begin{array}{c}H M-13 e \\
1\end{array}$ & $\begin{array}{c}\mathrm{HM}-13 \mathrm{e} \\
2\end{array}$ & $\begin{array}{c}\mathrm{Hm}-13 \mathrm{e} \\
3\end{array}$ & $\begin{array}{c}\mathrm{Hm}-13 \mathrm{e} \\
4\end{array}$ & $\begin{array}{c}\mathrm{HM}-13 \mathrm{e} \\
5\end{array}$ & $\begin{array}{c}H M-13 e \\
6\end{array}$ & $\begin{array}{c}H M-13 e \\
7\end{array}$ & $\begin{array}{c}\mathrm{HM}-13 \mathrm{e} \\
8\end{array}$ & $\begin{array}{c}H M-13 e \\
9\end{array}$ & $\begin{array}{c}H M-13 e \\
10\end{array}$ & $\begin{array}{c}\mathrm{Hm}-13 \mathrm{e} \\
12\end{array}$ & $\begin{array}{c}H M-13 e \\
13\end{array}$ & $\begin{array}{c}H M-13 e \\
14\end{array}$ & $\begin{array}{c}H M-13 e \\
15\end{array}$ \\
\hline $\mathrm{Al} 203$ & 79.67 & 78.99 & 80.04 & 78.58 & 78.75 & 79.10 & 79.28 & 79.01 & 79.37 & 77.62 & 79.53 & 80.20 & 79.30 & 79.96 \\
\hline $\mathrm{SiO} 2$ & nd & nd & nd & nd & nd & nd & nd & nd & nd & nd & nd & nd & nd & nd \\
\hline $\mathrm{T1O2}$ & nd & 0.09 & 0.06 & nd & 0.09 & 0.11 & 0.06 & 0.06 & 0.06 & 0.06 & 0.23 & 0.15 & 0.17 & 0.19 \\
\hline $\mathrm{Cr} 2 \mathrm{O} 3$ & 0.60 & 0.43 & 0.55 & 0.55 & 0.29 & 0.16 & 0.30 & 0.24 & 0.18 & 0.17 & 0.09 & 0.16 & 0.10 & 0.12 \\
\hline $\mathrm{Fe} 2 \mathrm{O} 3$ & 1.64 & 1.92 & 1.58 & 1.50 & 1.97 & 2.03 & 1.99 & 1.83 & 1.48 & 1.30 & 1.50 & 1.65 & 1.62 & 1.59 \\
\hline Mno & nd & 0.01 & nd & nd & nd & nd & 0.02 & nd & nd & nd & 0.01 & nd & nd & nd \\
\hline $\mathrm{Na} 2 \mathrm{O}$ & nd & nd & nd & nd & nd & nd & nd & nd & nd & nd & nd & nd & nd & nd \\
\hline Ta2O5 & nd & 0.02 & nd & nd & nd & nd & nd & 0.11 & 0.13 & nd & nd & nd & 0.16 & 0.05 \\
\hline Total & 81.91 & 81.45 & 82.23 & 80.63 & 81.10 & 81.39 & 81.65 & 81.24 & 81.22 & 79.15 & 81.36 & 82.15 & 81.34 & 81.92 \\
\hline $\mathrm{BeO}^{*}$ & 18.09 & 18.55 & 17.77 & 19.37 & 18.90 & 18.61 & 18.35 & 18.77 & 18.78 & 20.85 & 18.64 & 17.85 & 18.66 & 18.08 \\
\hline $\mathrm{Cr}$ & 0.0079 & 0.0057 & 0.0072 & 0.0072 & 0.0038 & 0.0021 & 0.0040 & 0.0031 & 0.0024 & 0.0022 & 0.0012 & 0.0020 & 0.0013 & 0.0016 \\
\hline $\mathrm{Fe}$ & 0.0204 & 0.0239 & 0.0197 & 0.0187 & 0.0246 & 0.0253 & 0.0248 & 0.0228 & 0.0185 & 0.0162 & 0.0187 & 0.0206 & 0.0203 & 0.0198 \\
\hline $\mathrm{Ti}$ & 0.0000 & 0.0011 & 0.0007 & 0.0000 & 0.0011 & 0.0013 & 0.0008 & 0.0007 & 0.0007 & 0.0008 & 0.0029 & 0.0019 & 0.0021 & 0.0024 \\
\hline $\mathrm{Cr} / \mathrm{Cr}+\mathrm{Fe}$ & 0.28 & 0.19 & 0.27 & 0.28 & 0.13 & 0.08 & 0.14 & 0.12 & 0.11 & 0.12 & 0.06 & 0.09 & 0.06 & 0.07 \\
\hline $\mathrm{Cr} / \mathrm{Cr}+\mathrm{Ti}$ & 1.00 & 0.84 & 0.91 & 1.00 & 0.77 & 0.61 & 0.84 & 0.82 & 0.77 & 0.74 & 0.30 & 0.52 & 0.38 & 0.40 \\
\hline $\mathrm{Cr} / \mathrm{Cr}+\mathrm{Fe}+\mathrm{Ti}$ & 0.28 & 0.18 & 0.26 & 0.28 & 0.13 & 0.07 & 0.13 & 0.12 & 0.11 & 0.12 & 0.05 & 0.08 & 0.05 & 0.07 \\
\hline
\end{tabular}

\begin{tabular}{|c|ccccc|}
\hline amostra & $H M-13 e$ & $H M-13 e$ & $H M-13 e$ & $H M-13 e$ & $H M-13 e$ \\
ponto & 16 & 17 & 18 & 19 & 20 \\
\hline $\mathrm{Al} 2 \mathrm{O} 3$ & 79.78 & 79.62 & 80.41 & 78.98 & 79.54 \\
$\mathrm{SiO} 2$ & nd & nd & nd & nd & nd \\
$\mathrm{TiO} 2$ & 0.24 & 0.20 & 0.22 & 0.21 & 0.24 \\
$\mathrm{Cr} 2 \mathrm{O} 3$ & 0.12 & 0.11 & 0.11 & 0.12 & 0.20 \\
$\mathrm{Fe} 2 \mathrm{O} 3$ & 1.50 & 1.51 & 1.58 & 1.62 & 1.52 \\
$\mathrm{MnO}$ & nd & nd & nd & nd & 0.02 \\
$\mathrm{Na} 2 \mathrm{O}$ & nd & nd & nd & nd & nd \\
$\mathrm{Ta2O5}$ & nd & 0.11 & nd & nd & 0.12 \\
$\mathrm{Total}$ & 81.63 & 81.55 & 82.31 & 80.92 & 81.64 \\
$\mathrm{BeO}$ & 18.37 & 18.45 & 17.69 & 19.08 & 18.36 \\
$\mathrm{Cr}$ & 0.0016 & 0.0014 & 0.0014 & 0.0015 & 0.0027 \\
$\mathrm{Fe}$ & 0.0187 & 0.0189 & 0.0197 & 0.0202 & 0.0189 \\
$\mathrm{Ti}$ & 0.0029 & 0.0025 & 0.0027 & 0.0026 & 0.0030 \\
$\mathrm{Cr} / \mathrm{Cr}+\mathrm{Fe}$ & 0.08 & 0.07 & 0.07 & 0.07 & 0.12 \\
$\mathrm{Cr} / \mathrm{Cr}+\mathrm{Ti}$ & 0.35 & 0.36 & 0.34 & 0.37 & 0.47 \\
$\mathrm{Cr} / \mathrm{Cr}+\mathrm{Fe}+\mathrm{Ti}$ & 0.07 & 0.06 & 0.06 & 0.06 & 0.11 \\
\hline
\end{tabular}

Tab.IX.1: cont. 


\begin{tabular}{|c|c|c|c|c|c|c|c|c|c|c|c|c|}
\hline $\begin{array}{c}\text { amostra } \\
\text { perfil-ponto } \\
\text { cor de CL }\end{array}$ & $\begin{array}{c}\text { EM-5 } \\
\text { a-1 } \\
\text { vermelho } \\
\text { apagado }\end{array}$ & $\begin{array}{c}\text { EM-5 } \\
\text { a-6 } \\
\text { vermelho } \\
\text { apagado }\end{array}$ & $\begin{array}{c}\text { EM-5 } \\
\text { a-3 } \\
\text { vermelho } \\
\text { apagado }\end{array}$ & $\begin{array}{c}\text { EM-5 } \\
a-4 \\
\text { vermelho }\end{array}$ & $\begin{array}{c}\text { EM-5 } \\
\text { a-5 } \\
\text { vermelho }\end{array}$ & $\begin{array}{c}\text { EM-5 } \\
\text { a-2 } \\
\text { vermetho }\end{array}$ & $\begin{array}{c}E M-5 z \\
b-1 \\
\text { marrom }\end{array}$ & $\begin{array}{c}\text { EM-5z } \\
b-2 \\
\text { marrom }\end{array}$ & $\begin{array}{c}E M-5 z \\
b-3 \\
\text { marrom }\end{array}$ & $\begin{array}{c}E M-5 z \\
b-4 \\
\text { vermetho } \\
\text { vivo }\end{array}$ & $\begin{array}{c}E M-5 z \\
b-5 \\
\text { vermelho } \\
\text { vivo }\end{array}$ & $\begin{array}{c}E M-5 z \\
b-6 \\
\text { vermelho } \\
\text { vivo }\end{array}$ \\
\hline $\mathrm{SiO}_{2}$ & 0.02 & nd & nd & 0.02 & 0.01 & 0.01 & 0.02 & 0.03 & nd & 0.06 & nd & 0.02 \\
\hline $\mathrm{THO}_{2}$ & 0.12 & 0.19 & 0.05 & 0.25 & 0.16 & 0.16 & 0.29 & 0.26 & 0.16 & 0.12 & 0.11 & 0.18 \\
\hline $\mathrm{Al}_{2} \mathrm{O}_{3}$ & 77.68 & 76.88 & 76.34 & 76.19 & 76.62 & 77.16 & 76.99 & 77.00 & 77.45 & 77.32 & 77.13 & 77.29 \\
\hline $\mathrm{Cl}_{2} \mathrm{O}_{3}$ & 0.49 & 0.59 & 0.57 & 0.71 & 0.75 & 0.79 & 0.63 & 0.62 & 0.69 & 0.59 & 0.59 & 0.48 \\
\hline Zno & 0.06 & 0.02 & nd & nd & nd & nd & 0.02 & nd & nd & nd & 0.02 & 0.06 \\
\hline $\mathrm{Fe}_{2} \mathrm{O}_{3}$ & 0.68 & 0.71 & 0.68 & 0.93 & 0.90 & 0.96 & 0.63 & 0.68 & 0.65 & 0.55 & 0.70 & 0.75 \\
\hline Mno & nd & nd & 0.01 & nd & nd & 0.01 & 0.01 & nd & nd & 0.03 & nd & 0.02 \\
\hline $\mathrm{MgO}$ & 0.01 & nd & nd & 0.02 & nd & 0.02 & 0.02 & no & 0.01 & nd & nd & 0.01 \\
\hline $\mathrm{NiO}$ & nd & nd & nd & nd & 0.03 & 0.02 & nd & 0.03 & 0.01 & nd & 0.02 & nd \\
\hline $\mathrm{CaO}$ & nd & nd & nd & nd & 0.01 & nd & nd & nd & nd & 0.01 & nd & nd \\
\hline $\mathrm{Na}_{2} \mathrm{O}$ & nd & nd & 0.02 & nd & nd & 0.03 & 0.02 & nd & 0.01 & 0.02 & 0.01 & nd \\
\hline $\mathrm{K}_{2} \mathrm{O}$ & 0.01 & 0.01 & nd & nd & 0.01 & nd & nd & 0.01 & nd & nd & 0.02 & nd \\
\hline Total & 79.07 & 78.40 & 77.65 & 78.11 & 78.51 & 79.15 & 78.62 & 78.63 & 78.98 & 78.70 & 78.59 & 78.80 \\
\hline $\mathrm{BeO}$ * & 20.93 & 21.60 & 22.35 & 21.90 & 21.49 & 20.85 & 21.39 & 21.37 & 21.02 & 21.30 & 21.41 & 21.20 \\
\hline $\mathrm{Cr}$ & 0.0064 & 0.0077 & 0.0075 & 0.0093 & 0.0099 & 0.0103 & 0.0082 & 0.0081 & 0.0091 & 0.0077 & 0.0078 & 0.0063 \\
\hline $\mathrm{Fe}$ & 0.0085 & 0.0089 & 0.0084 & 0.0116 & 0.0112 & 0.0120 & 0.0078 & 0.0085 & 0.0081 & 0.0069 & 0.0087 & 0.0093 \\
\hline$\pi$ & 0.0015 & 0.0024 & 0.0006 & 0.0031 & 0.0020 & 0.0020 & 0.0036 & 0.0033 & 0.0020 & 0.0015 & 0.0013 & 0.0023 \\
\hline $\mathrm{Cr} / \mathrm{Cr}+\mathrm{Fe}$ & 0.43 & 0.47 & 0.47 & 0.45 & 0.47 & 0.46 & 0.51 & 0.49 & 0.53 & 0.53 & 0.47 & 0.40 \\
\hline $\mathrm{Cr} / \mathrm{Cr}+\mathrm{Ti}$ & 0.81 & 0.76 & 0.93 & 0.75 & 0.83 & 0.84 & 0.69 & 0.71 & 0.82 & 0.84 & 0.86 & 0.73 \\
\hline $\mathrm{Cr} / \mathrm{Cr}+\mathrm{Fe}+\mathrm{Ti}$ & 0.39 & 0.41 & 0.46 & 0.39 & 0.43 & 0.42 & 0.42 & 0.41 & 0.47 & 0.48 & 0.44 & 0.35 \\
\hline
\end{tabular}

Tab.IX.2: Análises químicas por microssonda eletrônica de amostras de alexandrita das lavras de Esmeraldas de Ferros (EM) e Hematita (HM) com a indicação da cor de catodoluminescência observada.

*: por diferença; $(x-x)$ : perfil-ponto; $\mathrm{Cr}$, Fe e Ti: proporções atômicas. 


\begin{tabular}{|c|c|c|c|c|c|c|c|c|c|c|c|}
\hline $\begin{array}{l}\text { amostra } \\
\text { perfil-ponto } \\
\text { cor de } \mathrm{CL}\end{array}$ & $\begin{array}{c}\mathrm{HM}-13 \mathrm{~h} \\
\text { a-1 } \\
\text { vermetho } \\
\text { escuro }\end{array}$ & $\begin{array}{c}\mathrm{HM}-13 \mathrm{~h} \\
\text { a-6 } \\
\text { vermelho } \\
\text { escuro }\end{array}$ & $\begin{array}{c}\text { HM-13h } \\
\text { a-2 } \\
\text { vermetho } \\
\text { escuro }\end{array}$ & $\begin{array}{c}\text { HM13h } \\
\text { a-3 } \\
\text { laranja }\end{array}$ & $\begin{array}{c}\text { HM-13h } \\
\text { a-5 } \\
\text { laranja }\end{array}$ & $\begin{array}{c}\text { HM-13h } \\
\text { a-4 } \\
\text { Iaranja }\end{array}$ & $\begin{array}{c}\mathrm{HM}-13 \mathrm{~h} \\
\mathrm{~b}-1 \\
\text { vermetho } \\
\text { apagado }\end{array}$ & $\begin{array}{c}\text { HM-13h } \\
\text { b-5 } \\
\text { vermelho } \\
\text { apagado }\end{array}$ & $\begin{array}{c}\text { HM-13h } \\
\text { b-2 } \\
\text { vermelho } \\
\text { apagado }\end{array}$ & $\begin{array}{c}\text { HM-13h } \\
\text { b-3 } \\
\text { laranja }\end{array}$ & $\begin{array}{c}\mathrm{HM}-13 \mathrm{~h} \\
\mathrm{~b}-4 \\
\text { laranja }\end{array}$ \\
\hline $\mathrm{SiO}_{2}$ & 0.01 & 0.02 & nd & nd & 0.04 & 0.02 & nó & nd & nd & 0.03 & 0.01 \\
\hline $\mathrm{TH}_{2}$ & 0.17 & 0.11 & 0.14 & 0.07 & 0.04 & nd & 0.04 & 0.03 & 0.15 & 0.14 & 0.08 \\
\hline $\mathrm{Al}_{2} \mathrm{O}_{3}$ & 77.16 & 77.58 & 77.19 & 77.49 & 78.12 & 77.87 & 77.52 & 77.41 & 77.61 & 77.68 & 76.55 \\
\hline $\mathrm{Cr}_{2} \mathrm{O}_{3}$ & 0.14 & 0.14 & 0.15 & 0.20 & 0.16 & 0.20 & 0.09 & 0.16 & 0.18 & 0.14 & 0.11 \\
\hline $\mathrm{ZnO}$ & nd & 0.04 & nd & nd & nd & nd & 0.07 & nd & nd & 0.02 & nd \\
\hline $\mathrm{Fe}_{2} \mathrm{O}_{3}$ & 1.34 & 1.19 & 1.32 & 1.12 & 1.16 & 1.09 & 1.19 & 1.26 & 1.17 & 1.20 & 1.14 \\
\hline Mno & 0.02 & nd & 0.01 & 0.02 & nd & nd & nd & 0.01 & 0.01 & nd & nd \\
\hline $\mathrm{MgO}$ & 0.01 & nd & 0.02 & nd & nd & nd & 0.01 & nd & nd & nd & nd \\
\hline $\mathrm{NiO}$ & 0.02 & nd & 0.02 & nd & 0.01 & 0.02 & nd & 0.03 & 0.03 & 0.03 & 0.01 \\
\hline $\mathrm{CaO}$ & nd & 0.01 & 0.01 & nd & 0.01 & 0.01 & nd & 0.01 & 0.01 & nd & nd \\
\hline $\mathrm{Na}_{2} \mathrm{O}$ & nd & 0.01 & 0.02 & nd & nd & nd & nd & 0.01 & 0.01 & nd & 0.01 \\
\hline $\mathrm{K}_{2} \mathrm{O}$ & nd & 0.03 & nd & nd & 0.02 & 0.01 & nd & nd & nd & 0.01 & nd \\
\hline Total & 78.87 & 79.13 & 78.87 & 78.90 & 79.54 & 79.22 & 78.92 & 78.91 & 79.16 & 79.25 & 77.92 \\
\hline $\mathrm{BeO}^{*}$ & 21.13 & 20.87 & 21.13 & 21.10 & 20.46 & 20.78 & 21.08 & 21.10 & 20.84 & 20.75 & 22.08 \\
\hline $\mathrm{Cr}$ & 0.0019 & 0.0018 & 0.0019 & 0.0027 & 0.0021 & 0.0026 & 0.0012 & 0.0021 & 0.0024 & 0.0019 & 0.0015 \\
\hline $\mathrm{Fe}$ & 0.0168 & 0.0149 & 0.0164 & 0.0139 & 0.0445 & 0.0137 & 0.0148 & 0.0157 & 0.0146 & 0.0150 & 0.0142 \\
\hline $\mathrm{Ti}$ & 0.0021 & 0.0013 & 0.0017 & 0.0008 & 0.0005 & 0.0000 & 0.0005 & 0.0003 & 0.0018 & 0.0018 & 0.0010 \\
\hline $\mathrm{Cr} / \mathrm{Cr}+\mathrm{Fe}$ & 0.10 & 0.11 & 0.11 & 0.16 & 0.12 & 0.16 & 0.07 & 0.12 & 0.14 & 0.11 & 0.09 \\
\hline $\mathrm{Cr} / \mathrm{Cr}+\mathrm{Ti}$ & 0.47 & 0.58 & 0.53 & 0.76 & 0.82 & 1.00 & 0.71 & 0.85 & 0.56 & 0.51 & 0.58 \\
\hline $\mathrm{Cr} / \mathrm{Cr}+\mathrm{Fe}+\mathrm{Ti}^{2}$ & 0.09 & 0.10 & 0.10 & 0.15 & 0.12 & 0.16 & 0.07 & 0.11 & 0.13 & 0.10 & 0.09 \\
\hline
\end{tabular}

Tab.IX.2: cont. 
Nas amostras de Esmeraldas de Ferros, observa-se a tendência dos teores em $\mathrm{Fe}_{2} \mathrm{O}_{3}$ em igualarem-se a $\mathrm{Cr}_{2} \mathrm{O}_{3}$, em oposição a valores de $\mathrm{Fe}_{2} \mathrm{O}_{3}$ sempre mais elevados (acima de 1,00\%) em Hematita. Os teores em $\mathrm{TiO}_{2}$ são bastante variados para ambas as ocorrências, apresentando-se geralmente inferiores à concentração em $\mathrm{Cr}_{2} \mathrm{O}_{3}$.

\section{IX.C.2. Efeito alexandrita}

Para possibilitar a correlação entre composição química e efeito alexandrita, de cada ocorrência foi selecionada uma amostra apresentando zoneamento na intensidade do fenômeno para a realização de perfis analíticos com a microssonda eletrônica.

A amostra de Hematita (Prancha 8-C) apresenta zoneamento bem marcante, com mudança de cor intensa na borda (azul a vinho) e fraca em direção ao centro do grão (verde a castanho-esverdeado).

Da Lavra de Esmeraldas de Ferros selecionou-se um fragmento de um geminado cíclico (Prancha 8-E), onde a porção externa exibe mudança de cor fraca (verde a arroxeado) em contraste com a região central, onde a cor é vermelha, sem efeito alexandrita.

Nos perfis analíticos para as duas amostras (Prancha 8-D,F), é evidente a dependência da intensidade do efeito alexandrita em função do teor em $\mathrm{Cr}$. Quanto ao papel do $\mathrm{Ti}$, sua contribuição para diminuir a intensidade da mudança de cor não parece relevante, ressaltando-se no entanto sua presença em teores elevados (em torno de $0,006 \mathrm{Ti}$ na amostra EM-5M2) associada à coloração castanhoaveremelhada no crisoberilo, anulando o efeito alexandrita apesar da presença de Cr.

Ainda analisando-se os perfis, é possível concluir que a concentração de Fe não tem influência sobre a intensidade da mudança de cor da alexandrita. No entanto, seus teores mais baixos nas amostras de Esmeraldas de Ferros (Tab.IX.1 e IX.2) encontram correspondência na cor mais azulada do material dessa ocorrência em oposição ao tom simplesmente verde da alexandita de Hematita.

Esse fenômeno foi investigado por Pinheiro et al. (2000) em alexandrita "azul-pavão" de Malacacheta, MG, e explicado com base na intensidade das linhas 


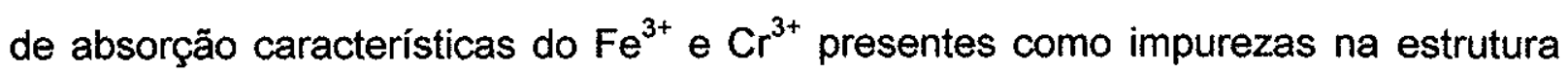
do mineral.

IX.C.3. Catodoluminescência

O fenômeno de catodoluminescência foi estudado em duas amostras de alexandrita da Lavra de Hematita e duas da Lavra de Esmeraldas de Ferros, tendo sido obtidos os espectros da luminescência resultante apresentados na figura IX.1.

Confirmando observações de Gaal (1976/77), a cor apresentada por todas as amostras de alexandrita em resposta ao feixe de eletrons foi o vermelho, variando entre apagado e intenso, tendendo ao laranja (Prancha 8-G).

Os espectros (Fig.IX.1) são todos muito semelhantes, podendo-se reconhecer uma linha de emissão principal a $1,82 \mathrm{eV}(681 \mathrm{~nm})$ e uma linha secundária a $1,76 \mathrm{eV}(703 \mathrm{~nm})$. Com exceção da amostra HM-18a, que apresenta um espectro menos definido, constata-se que a linha de emissão principal constitui-se em um doublet com duas linhas a 1,82 e $1,84 \mathrm{eV}$.

Essas mesmas características foram observadas na análise de uma amostra de alexandrita sintética russa, produzida pelo método de síntese hidrotermal (Fig.IX.2), indicando que a catodoluminescência, ao contrário da esmeralda, provavelmente não constitui um método útil no reconhecimento de material sintético.

Com base na intensidade das cores de catodoluminescência observadas, foram realizados quatro perfis analíticos com o uso da microssonda eletrônica, buscando-se o reconhecimento da influência da composição química sobre a $\mathrm{CL}$ (Tab.IX.2).

Nota-se, conforme já previsto por Ponahlo (1993), que a uma cor vermelha mais intensa associam-se teores mais elevados de $\mathrm{Cr}_{2} \mathrm{O}_{3}$, como nas amostras EM-5 e HM-13h (perfil a), onde observa-se passagem de catodoluminescência de cor vermelho apagado ou escuro para vermelho ou laranja. No entanto, elementos considerados inibidores pelo mesmo autor, como $\mathrm{Ti}$ e $\mathrm{Fe}$, também podem apresentar teores mais elevados, resultando em um comportamento aleatório das razões $\mathrm{Cr} / \mathrm{Fe}, \mathrm{Cr} / \mathrm{Ti}$ e $\mathrm{Cr} / \mathrm{Fe}+\mathrm{Ti}$. Esses dados sugerem portanto que o fenômeno da catodoluminescência na alexandrita independe dos teores em $\mathrm{Fe}$ e $\mathrm{Ti}_{\text {, }}$ havendo no entanto um valor máximo para a concentração de $\mathrm{Ti}$ acima do qual o 
crisoberilo deixa de apresentar mudança de cor (como já descrito no item anterior), além de emitir CL muito fraca, de cor marrom (amostra EM-5z).

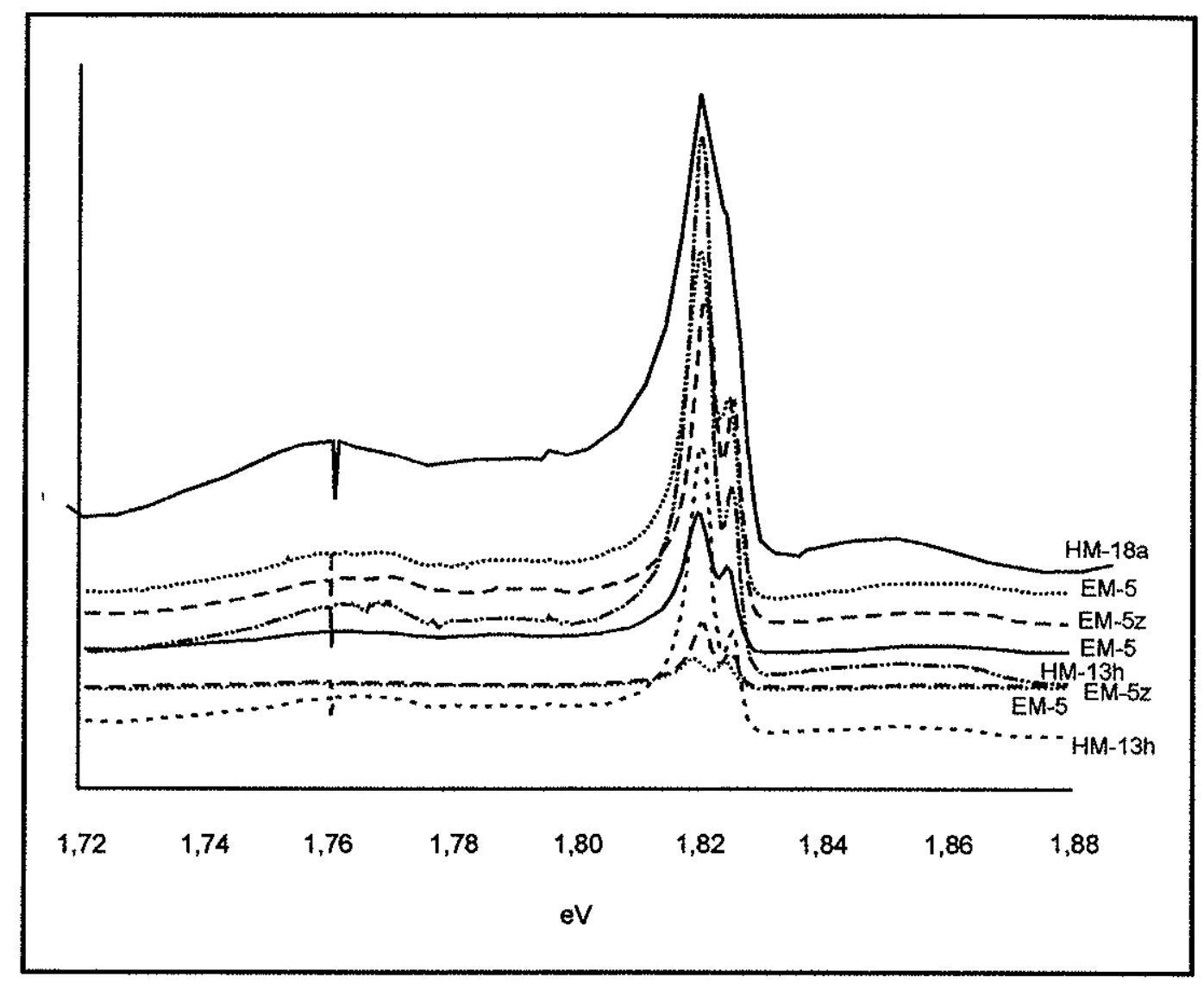

Fig.IX.1: Espectros de absorção da catodoluminescência observada nas alexandritas das lavras de Esmeraldas de Ferros (EM) e Hematita (HM).

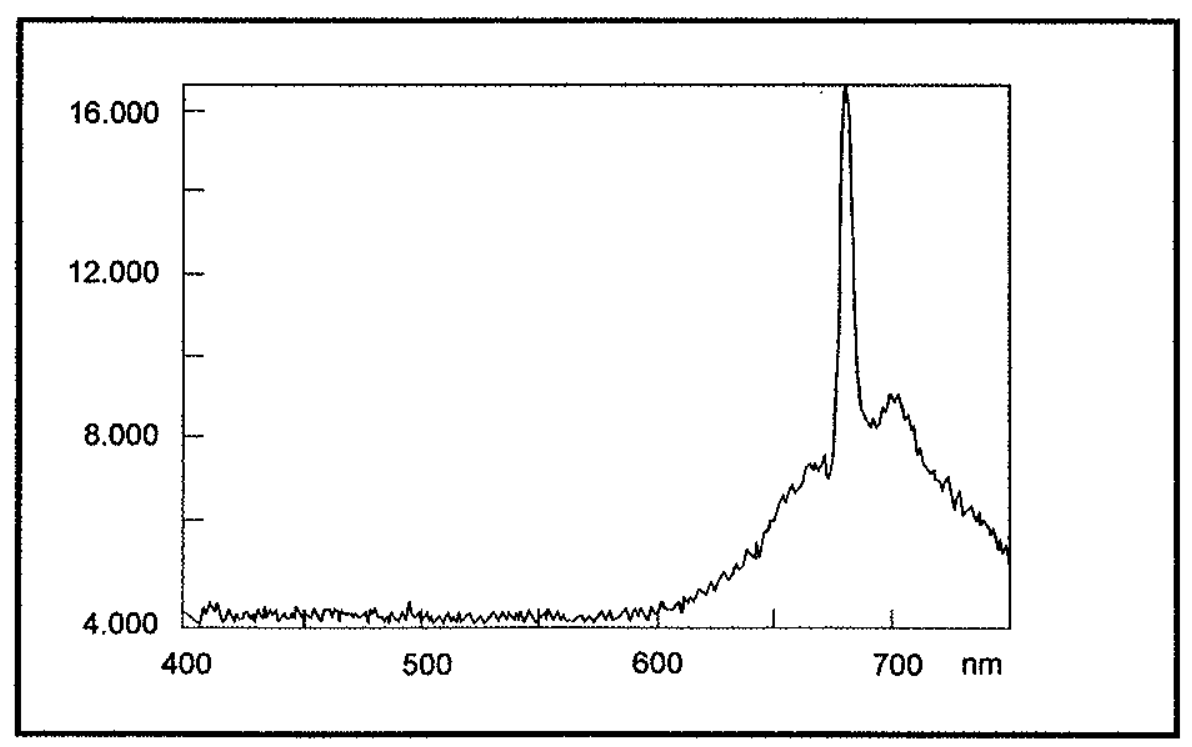

Fig.IX.2: Espectro de absorção da catodoluminescência observada em alexandrita sintética produzida por processo hidrotermal. 
IX.D. Espectros de Absorção no Infravermelho

Os espectros de absorção na região do infravermelho provêm de quatro amostras de alexandrita da Lavra de Esmeraldas de Ferros e quatro da Lavra de Hematita.

Todas as amostras apresentaram espectros bastante semelhantes, onde destacam-se as linhas de absorção em torno de 3200 e $1840 \mathrm{~cm}^{-1}$ (Fig.IX.3). Outras linhas menos intensas também são comuns a quase todos os espectros, podendo ocorrer na forma de uma única faixa, de um doublet ou mesmo triplet, como no caso da absorção em torno de $2400 \mathrm{~cm}^{-1}$ nas amostras EM-5B, EM-5D e HM-24 (Tab.IX.3). A linha de absorção em torno de $2000-2040 \mathrm{~cm}^{-1}$ está claramente presente em apenas três espectros (EM-5C, EM-5D e HM-23), porém nos demais existe sempre uma banda pouco definida.

Segundo as análises efetuadas por Stockton \& Kane (1988) e Henn (1992) em alexandritas naturais e sintéticas, a separação entre esses materiais é possivel devido à presença de linhas de absorção características da presença de $\mathrm{H}_{2} \mathrm{O}$ ou $\mathrm{OH}$ na alexandrita natural, incorporados tanto à estrutura do mineral quanto na forma de inclusões fluidas. Ainda segundo os mencionados autores, a alexandrita sintética produzida em meio anidro (métodos de Fluxo, Czochralski ou Floating Zone) não apresenta as vibrações características da água, enquanto a alexandrita resultante de síntese hidrotermal pode ser reconhecida pela menor intensidade dessas vibrações (Henn op. cit.).

No entanto, esses autores divergem quanto a quais linhas de absorção seriam diagnósticas da origem do material.

Em trabalho mais recente, Bauerhansl \& Beran (1997) obtiveram espectros polarizados em amostras orientadas de crisoberilo natural e puderam determinar as linhas de menor transmitância (ou maior absorção) relacionadas à presença de moléculas de $\mathrm{OH}$ orientadas segundo [100] na estrutura do mineral. $A$ banda de alta energia corresponde a um doublet entre 3234 e $3219 \mathrm{~cm}^{-1}$ (Fig.lX.3 detalhe), que em amostras não orientadas pode apresentar-se como uma única banda ao redor de $3230 \mathrm{~cm}^{-1}$, enquanto a banda de baixa energia situa-se a $3135 \mathrm{~cm}^{-}$ 1 . 


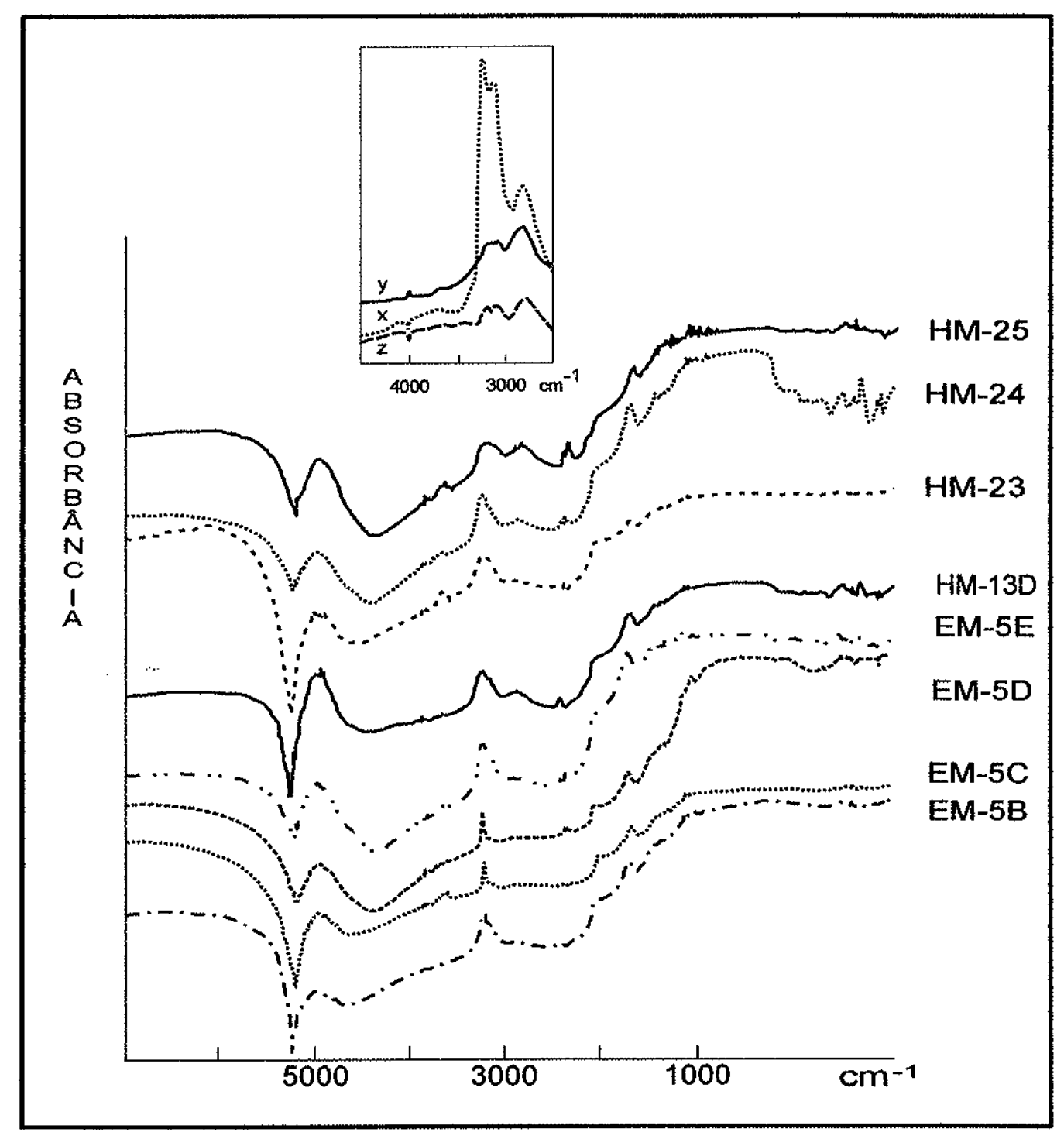

Fig.IX.3: Espectros de absorção no infravermelho em amostras não orientadas de alexandrita das lavras de Esmeraldas de Ferros (EM) e Hematita (HM). No detalhe: espectros de absorção polarizados obtidos em amostras de crisoberilo natural por

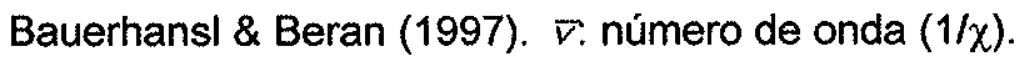

Comparando-se os resultados dos autores com os obtidos neste trabalho, pode ser reconhecida a banda típica da alexandrita natural, bem individualizada em torno de $3200 \mathrm{~cm}^{-1}$ (Fig.IX.3, Tab.IX.3).

A banda em torno de $2840 \mathrm{~cm}^{-1}$, que foi atribuida pelos autores a vibrações das unidades $\mathrm{BeO}_{4}$, apresenta-se neste trabalho mais frequentemente como um doublet $\left(2910-2850 \mathrm{~cm}^{-1}\right)$ provavelmente devido à sobreposição dos espectros paralelos a $\mathbf{x}, \mathbf{y}$ e $\mathbf{z}$ nas amostras não orientadas. 


\begin{tabular}{|c|c|c|c|c|c|c|c|}
\hline EM-5B & EM-5C & EM-5D & EM-5E & HM-13D & HM-23 & HM-24 & HM-25 \\
\hline 5211 & 5200 & 5200 & 5200 & 5200 & 5200 & 5200 & 5200 \\
\hline 4960 & 4960 & 4952 & 4938 & 4938 & 4967 & 4941 & 4938 \\
\hline 4646 & 4640 & 4400 & 4350 & 4400 & 4640 & 4400 & 4300 \\
\hline 3223 & 3228 & 3227 & 3221 & 3222 & 3208 & 3221 & 3200 \\
\hline 2920 & & 2910 & 2910 & 2910 & 2922 & 2849 & 2920 \\
\hline 2850 & & 2840 & 2850 & 2850 & 2858 & & 2851 \\
\hline 2403 & 2350 & 2359 & 2361 & 2402 & 2410 & 2403 & 2403 \\
& & 2329 & 2336 & & & 2359 & 2360 \\
& & & & & & 2338 & 2341 \\
\hline 1843 & 1842 & 1824 & 1843 & 1842 & 1844 & 1843 & 1842 \\
\hline
\end{tabular}

Tab.IX.3: Linhas de absorção na regiäo do infravermelho em amostras não orientadas de alexandrita das lavras de Esmeraldas de Ferros (EM) e Hematita (HM). Valores correspondentes a $\nabla$ (número de onda) $\mathrm{em} \mathrm{cm}^{-1}$.

Após experimentos de deuteração (deuteration), Bauerhansl \& Beran (1997) constataram o surgimento de linhas adicionais a 2410 e $2318 \mathrm{~cm}^{-1}$, resultantes da substituição parcial de OH por OD. Nas amostras investigadas neste trabalho, e que não sofreram nenhum tipo de tratamento, essas linhas também são observadas em torno de $2400-2330 \mathrm{~cm}^{-1}$, porém nenhuma explicação é proposta para esse fato.

Comparando-se os espectros das amostras da Lavra de Esmeraldas de Ferros com as da Lavra de Hematita, nota-se nas últimas uma tendência ao alargamento na faixa em torno de $3200 \mathrm{~cm}^{-1}$, ou seja, uma melhor individualização do doublet observado por Bauerhansl \& Beran (1997) na região de vibração correspondente ao dipolo $\mathrm{OH}$. Esse fato poderia significar diferenças no ambiente de formação das duas ocorrências (diferenças na disponibilidade de fluidos, principalmente $\mathrm{H}_{2} \mathrm{O}$ ), uma vez que os autores constataram que, após experimentos de desidratação, as duas linhas constituintes do doublet tendem a fundir-se numa só. 
IX.E. Parâmetros de Cela Unitária

As constantes cristalográficas determinadas para amostras de crisoberilo comum, alexandrita e olho-de-gato encontram-se na tabela IX.4.

\begin{tabular}{|c|c|c|c|}
\hline amostra & $a_{0}$ & $b_{0}$ & $c_{0}$ \\
\hline Farrell et al. (1963) & 9,404 & 5,476 & 4,427 \\
\hline $\mathrm{CN}-2 \mathrm{C}$ & 9,4060 & 5,4798 & 4,4322 \\
\hline $\mathrm{CN}-2 \mathrm{D}$ & 9,417 & 5,4763 & 4,4311 \\
\hline QI-2B & 9,409 & 5,4793 & 4,4324 \\
\hline média & 9,411 & 5,4785 & 4,4319 \\
\hline $\mathrm{CN}-2 \mathrm{~B}^{(\mathrm{c})}$ & 9,4060 & 5,4763 & 4,4293 \\
\hline$H M-17 b^{(c)}$ & 9,4167 & 5,4797 & 4,4273 \\
\hline $\mathrm{Q} \mid-2^{(\mathrm{c})}$ & 9,4137 & 5,4808 & 4,4286 \\
\hline média & 9,4146 & 5,4795 & 4,4290 \\
\hline$\Delta$ & $\Delta a_{0} 0,0036$ & $\Delta b_{0}, 0,001$ & $\Delta c_{0} \quad 0,0029$ \\
\hline $\mathrm{CN}-3 \mathrm{~b}^{\text {(a) }}$ & 9,4167 & 5,4806 & 4,4307 \\
\hline $\mathrm{CN}-3^{(a)}$ & 9,4123 & 5,4770 & 4,4302 \\
\hline$H M-18 a^{(a)}$ & 9,4037 & 5,4811 & 4,4303 \\
\hline$H M-18 c^{\text {(a) }}$ & 9,4105 & 5,4817 & 4,4288 \\
\hline média & 9,4108 & 5,4801 & 4,4300 \\
\hline$C N-3 d^{(a)(c)}$ & 9,4183 & 5,4810 & 4,4314 \\
\hline$C N-4 b^{(a)(c)}$ & 9,4149 & 5,4776 & 4,4282 \\
\hline$E M-5 m^{(a)(c)}$ & 9,4141 & 5,4811 & 4,4302 \\
\hline$E M-5-1^{(a)(c)}$ & 9,4121 & 5,4786 & 4,4300 \\
\hline$E M-5-10^{(a)(c)}$ & 9,4146 & 5,4810 & 4,4307 \\
\hline$H M-18 d^{(a)(c)}$ & 9,4132 & 5,4796 & 4,4302 \\
\hline$H M-18 e^{(a)(c)}$ & 9,4130 & 5,4803 & 4,4306 \\
\hline média & 9,4143 & 5,4799 & 4,4302 \\
\hline$\Delta$ & $\Delta a_{0}: 0,0035$ & $\Delta b_{0}=0,0002$ & $\Delta \mathrm{c}_{0}: 0,0002$ \\
\hline
\end{tabular}

Tab.IX.4: Parâmetros de cela unitária para amostras de crisoberilo comum e alexandrita, com e sem efeito olho-de-gato. média: valores médios; $\Delta$ : diferenças entre os valores médios da mesma variedade; CN: Cruzeiro Novo, MG; EM: Lavra de Esmeraldas de Ferros; QI: Quilombo; ("): alexandrita; $\left({ }^{c}\right)$ : olho-de-gato. 
Todos os valores são ligeiramente superiores àqueles obtidos por Farrell et al. (1963) em seu trabalho de refinamento da estrutura do mineral, provavelmente pelo fato de os autores terem-se utilizado de crisoberilo obtido sinteticamente, sem a adição de elementos traço que pudessem substituir o Al e causar distorções na sua estrutura cristalina.

Os resultados analíticos obtidos no item referente à composição química da alexandrita (item IX.C) permitem associar a presença do efeito olho-de-gato a teores relativamente elevados em $\mathrm{TiO}_{2}$, sugerindo que a ocorrência do fenômeno de exsolução poderia causar alterações nos parâmetros de cela unitária do mineral.

Com o intuito de se verificar essa possibilidade, foram obtidos espectros de difratometria de raios $\mathrm{X}$ em amostras com e sem efeito olho-de-gato, tanto da variedade comum quanto alexandrita.

Os resultados e as médias para os valores de $a_{0}, b_{0}$ e $c_{0}$ encontram-se na tabela IX.4, tendo sido analisadas também amostras de Cruzeiro Novo (MG) para efeito de comparação.

Analisando-se os valores médios obtidos para crisoberilo amarelo com e sem efeito olho-de-gato, observa-se um aumento significativo no valor de $a_{0}(9,411$ para 9,4146) associado ao fenômeno de exsolução. Um aumento de mesma magnitude também ocorre no valor médio de $a_{0}$ para a alexandrita $(9,4108$ para 9,4143), enquanto os demais parâmetros, $b_{0}$ e $c_{0}$, apresentam comportamento aleatório.

Considerando-se a estrutura crisoberilo, onde cátions trivalentes como $\mathrm{Cr}$, $\mathrm{Fe}, \mathrm{Ti}, \mathrm{V}, \mathrm{Mn}$, Co e Ni podem substituir $\mathrm{Al}^{3+}$ em posições octaédricas (Farrell et al. 1963), e os raios iônicos do $A l^{3+}$ e $\mathrm{Ti}^{3+}$, respectivamente 0,53 e $0,67 \AA$ (Shannon \& Prewitt 1969), o comportamento observado é compatível com a presença do elemento de maior raio iônico em maior concentração na estrutura do mineral, causando ligeiro aumento nos parâmetros da cela unitária.

\section{IX.F. Resumo das Propriedades}

Analisando-se os dados obtidos no item referente à caracterização do crisoberilo, constata-se que tanto o material da Lavra de Esmeraldas de Ferros 
quanto de Hematita apresentam propriedades físicas (densidade, índice de refração, cor) dentro da faixa de variação encontrada na literatura para o mineral.

Entre a alexandrita proveniente das duas ocorrências, existe uma nítida diferenciação quanto à morfologia e propriedades gemológicas: enquanto a alexandrita de Esmeraldas de Ferros é encontrada na forma de cristais ou fragmentos de pequenas dimensões (inferiores a $0,5 \mathrm{~cm}$ ), pouco transparentes e ricos em inclusões sólidas, o material obtido em Hematita ocorre na forma de fragmentos de maior dimensão, apresenta transparência elevada e raras inclusões sólidas, o que Ihe confere alto valor gemológico.

O efeito olho-de-gato está ainda presente em praticamente todos os exemplares da Lavra de Esmeraldas de Ferros estudados, ao contrário do observado em Hematita, onde o fenômeno apresenta ocorrência mais restrita.

No tocante à composição química, a diferença principal reside nos teores em $\mathrm{Fe}_{2} \mathrm{O}_{3}$ menos elevados em Esmeraldas de Ferros em comparação com a alexandrita de Hematita, conferindo às primeiras um tom mais azulado.

Os espectros de absorção na região do infravermelho das amostras de alexandrita de Esmeraldas de Ferros e Hematita apresentam-se ligeiramente diferentes na região em torno de $3200 \mathrm{~cm}^{-1}$, enquanto os espectros de catodoluminescência não revelam diferenças significativas.

$\mathrm{Na}$ separação de material sintético, o espectro de absorção no infravermelho e o conjunto de inclusões sólidas seriam característicos das alexandritas de Esmeraldas de Ferros e Hematita. A presença de inclusões de grafita, até o momento não descritas em alexandritas de outras localidades, seria ainda uma feição típica do material de Esmeraldas de Ferros. 


\section{PRANCHA 6}

\section{LEGENDA}

A: Dois cristais de alexandrita de Esmeraldas de Ferros.

B: Dois fragmentos de alexandrita de Hematita.

C: Alexandrita de Hematita, exibindo efeito olho-de-gato restrito à porção central do grão. Estereomicroscópio, 1x.

D: alexandrita de Esmeraldas de Ferros, exibindo exsoluções de hábito acicular responsáveis pelo efeito olho-de-gato. A região de maior concentração das exsoluções apresenta coloração vermelha. Luz transmitida, nicóis $/ /, 50 x$.

E: Grãos corroídos de grafita inclusos em alexandrita de Esmeraldas de Ferros. Luz transmitida, nicóis $/ /, 20 x$.

F: Espectro de EDS de inclusão de grafita em alexandrita de Esemraldas de Ferros. A presença de Al é devida a restos do material usado no polimento.

G: Minerais opacos inclusos em alexandrita de Esmeraldas de Ferros. Luz refletida, nicóis $/ /, 5 x$. a, b, c: ilmenita; d: sulfeitos.

H: Detalhe da fotomicrografia G - associação de pirita, calcopirita e pentlandita. Luz refletida, nicóis //, 20x. 

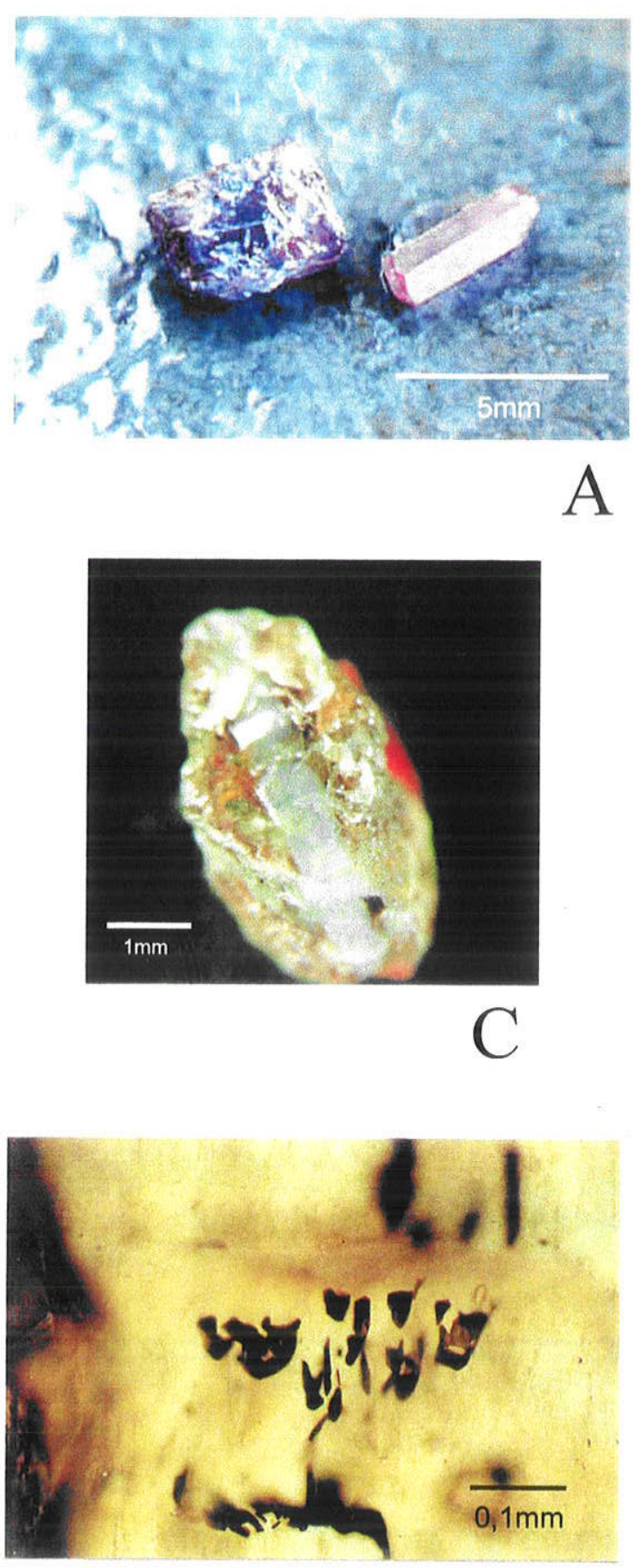

E

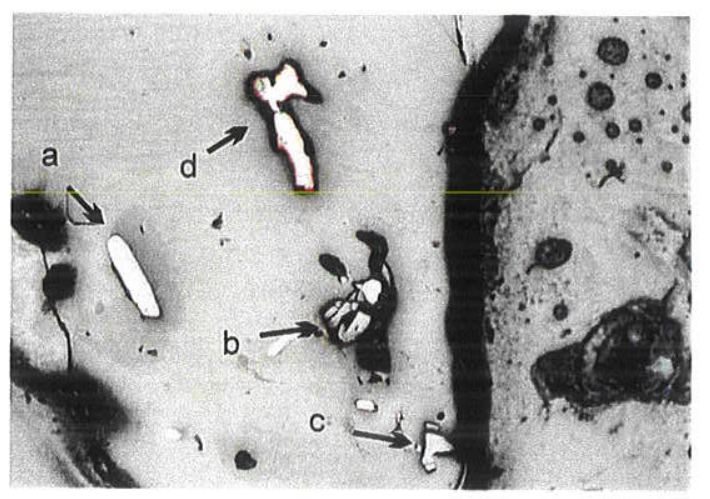

G
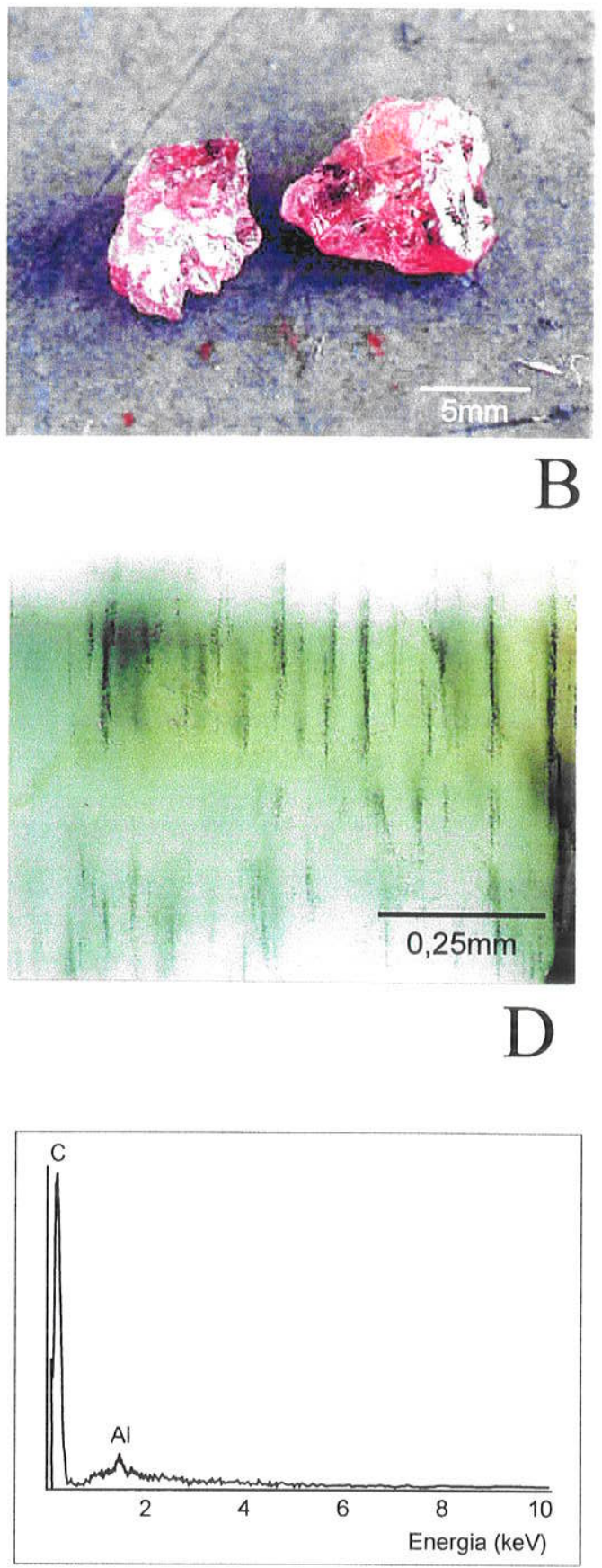

F

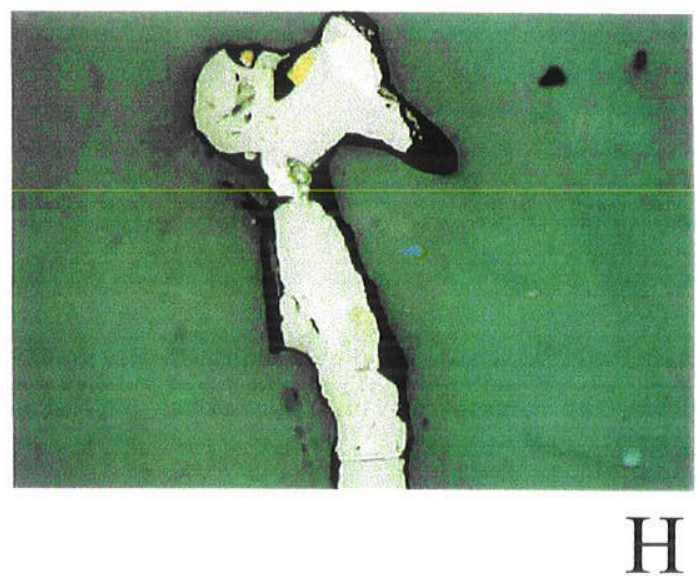




\section{PRANCHA 7}

\section{LEGENDA}

A: Inclusões de grãos euedrais de quartzo em alexandrita de Esmeraldas de Ferros. Luz transmitida, nicóis $/ /, 20 x$.

B: Espectro de EDS de inclusão de quartzo em alexandrita de Esmeraldas de Ferros.

C: Inclusão de augita em alexandrita de Esmeraldas de Ferros. Luz transmitida, nicóis $\perp$, 20x.

D: Espectro de EDS de inclusão de augita em alexandrita de Esmeraldas de Ferros.

E: Inclusão de quartzo em alexandrita de Hematita. Luz transmitida, nicóis /, $20 x$.

F: Espectro de EDS de inclusão de quartzo em alexandrita de Hematita.

G: Espectro de EDS de inclusão de titanomagnetita em alexandrita de Hematita.

H: Inclusão de mineral prismático (provavelmente um anfibólio) em alexandrita de Hematita. Luz transmitida, nicóis //, 20x. 


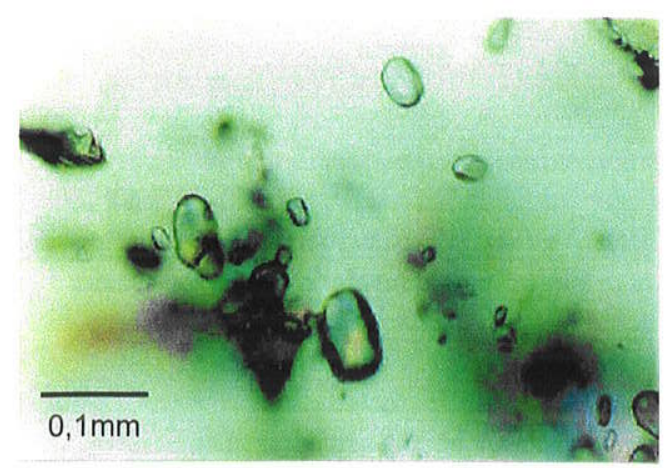

A

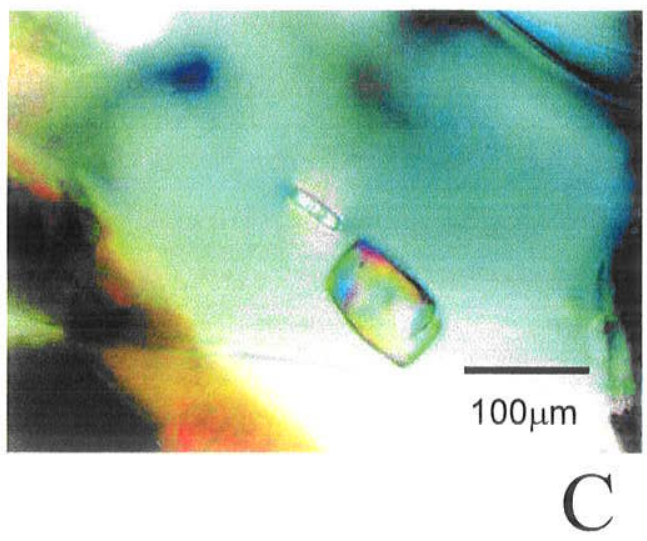

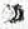

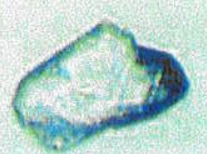

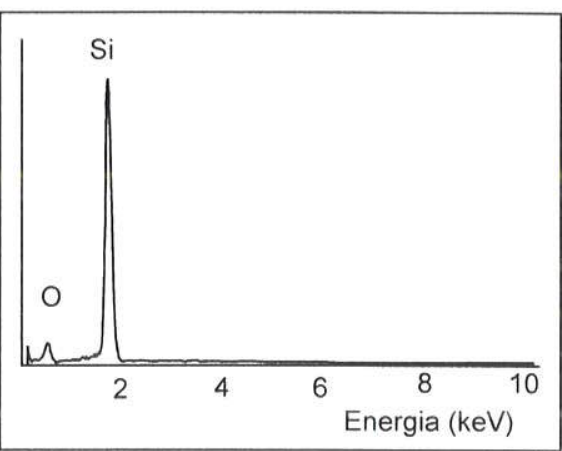

B
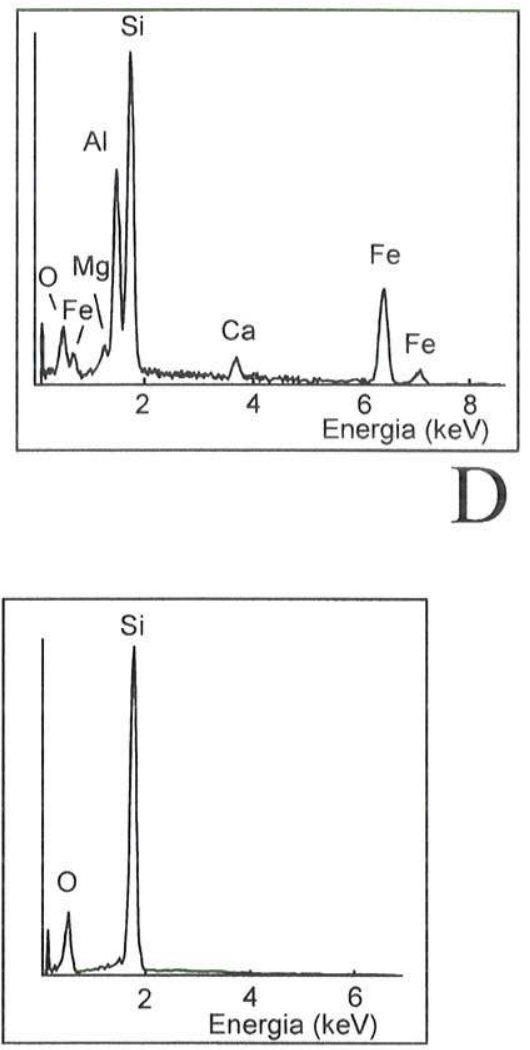

F

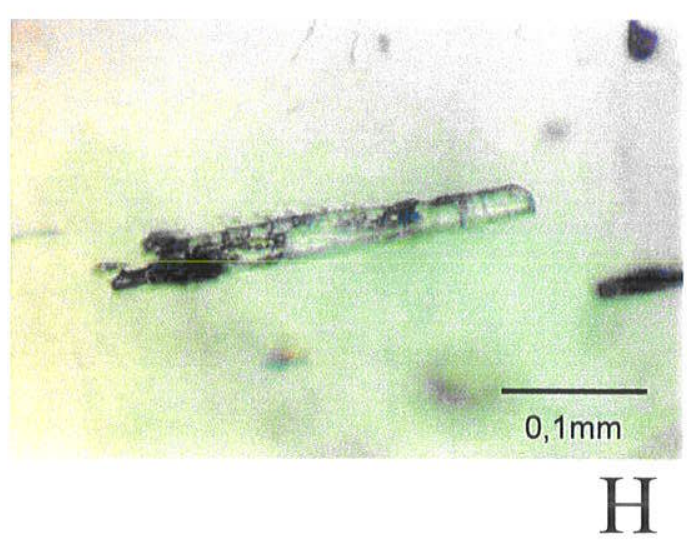




\title{
PRANCHA 8
}

\section{LEGENDA}

\begin{abstract}
A: Antigas inclusões fluidas preenchidas por sólidos birrefringentes em alexandrita de Hematita. Luz transmitida, nicóis //, 20x.
\end{abstract}

B: Espectro de EDS de sólido birrefringente preenchendo cavidades em alexandrita de Hematita.

C: Alexandrita de Hematita exibindo zoneamento no efeito alexanddrita. Região a: mudança de cor intensa (azul a vinho); região b: mudança de cor de fraca intensidade (verde a castanho-esverdeado). 1 a 20: perfil analítico.

D: Perfis analíticos de $\mathrm{Cr}$, Fe e Ti na amostra da figura $\mathrm{C}$.

E: Alexandrita de Esmeraldas de Ferros exibindo zoneamento. Região a: efeito alexandrita fraco (verde a arroxeado); região b: cor castanho-avermelhado, sem efeito alexandrita. 1 a 20: perfis analíticos.

F: Perfis analíticos de $\mathrm{Cr}$, Fe e Ti na amostra da figura $\mathrm{E}$.

G: Alexandrita de Hematita, aprsentando zoneamento na catodoluminescência: vermelho escuro a laranja. 


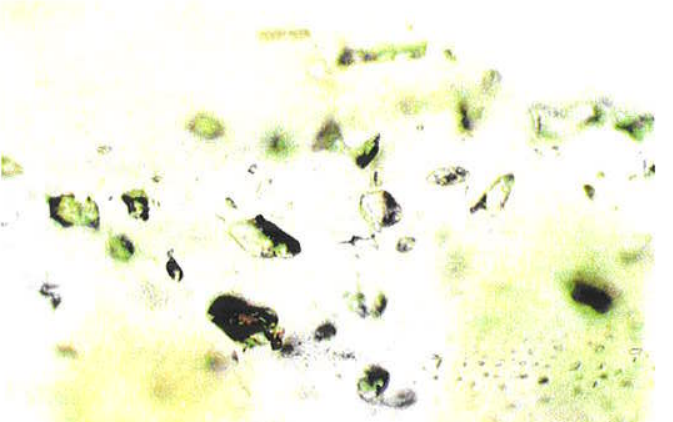

A
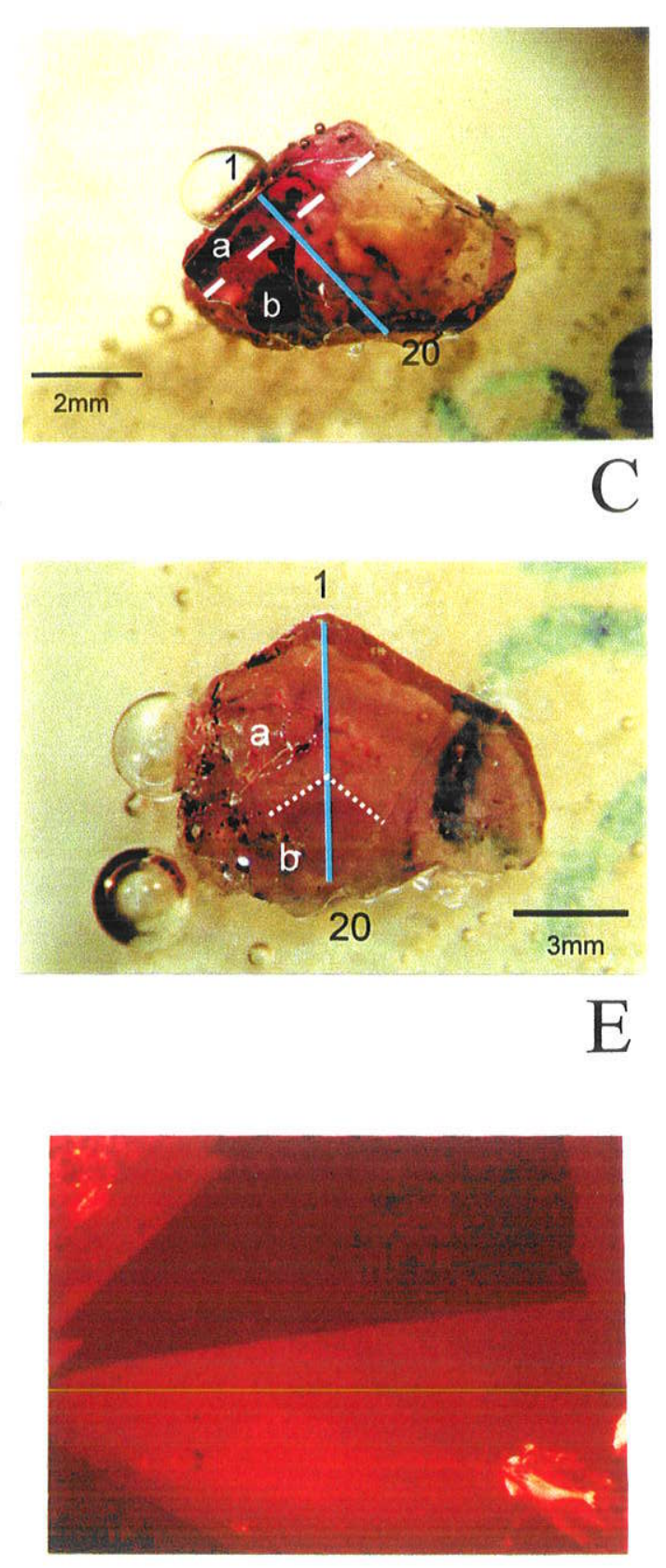

G
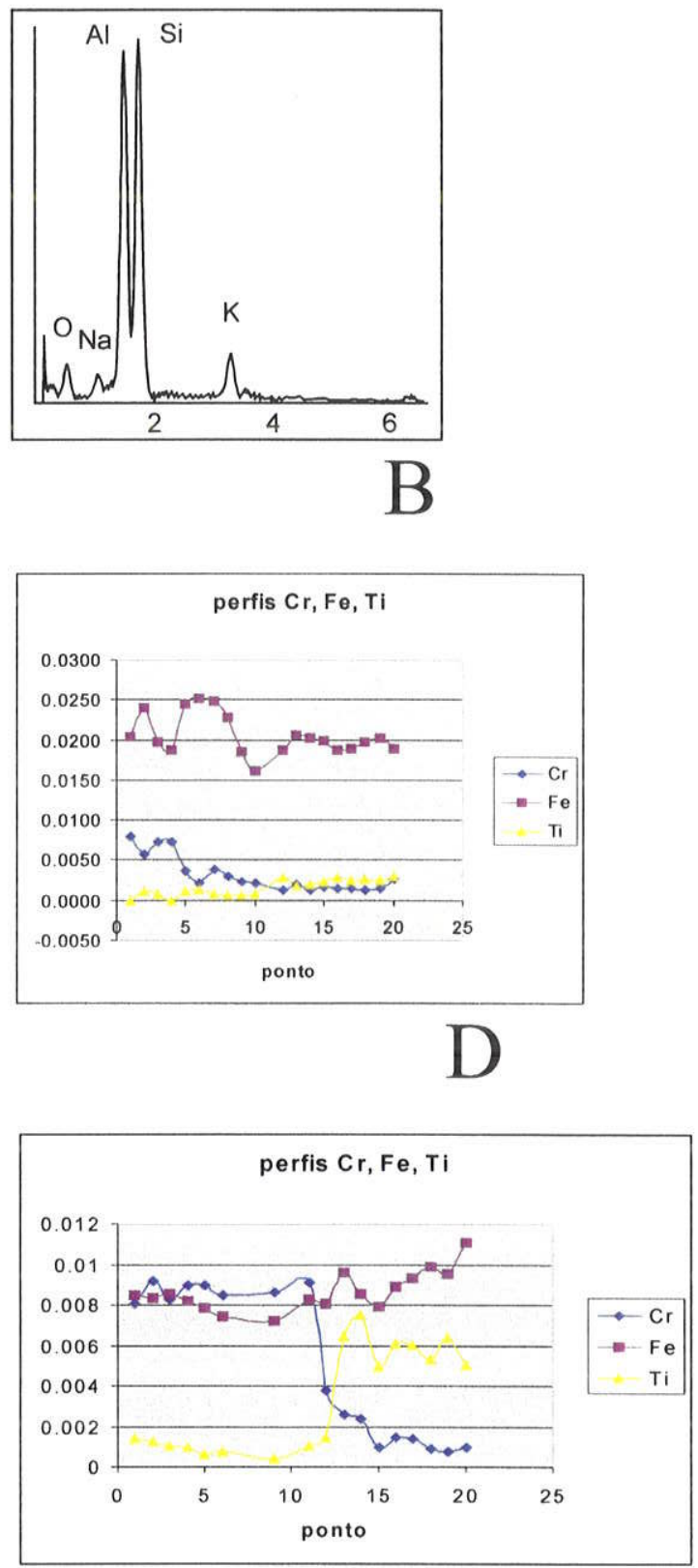

F 


\section{GÊNESE DO CRISOBERILO}

\section{X.A. Ocorrências Primárias de Crisoberilo}

Na natureza, o crisoberilo ocorre principalmente em pegmatitos e menos comumente em skarns, mármores dolomíticos e gnaisses (Henn 1995). Essa distribuição reflete o comportamento geoquímico do elemento $\mathrm{Be}$, investigado por vários autores (sumarizados por Wuensch \& Hörmann 1969) e que é típico de um elemento incompativel, com teores baixos em rochas básicas e relativamente mais elevados em rochas ácidas.

Alguns autores têm-se dedicado ao estudo de pegmatitos portadores de crisoberilo e à caracterização dos processos condicionantes da formação do mineral nesse ambiente geológico.

Segundo Beus (1966 apud Heinrich \& Buchi 1969), a formação do crisoberilo pode dar-se em duas classes de pegmatitos:

- pegmatitos dessilicificados, portadores de coríndon, espinélio, clorita, margarita, flogopita, muscovita, plagioclásio, fluorita e apatita;

- pegamtitos graníticos com contaminação por $\mathrm{Al}_{2} \mathrm{O}_{3}$, portadores de cianita, estaurolita, granada, muscovita, plagioclásio, gahnita, berilo, quartzo, etc.

Heinrich \& Buchi (1969) sustentam que nos pegmatitos graníticos a cristalização de crisoberilo não ocorre diretamente do fluido pegmatítico mas sim a partir de reações de consumo de berilo:

$$
\begin{aligned}
& \mathrm{Be}_{3} \mathrm{Al}_{2} \mathrm{Si}_{6} \mathrm{O}_{18}+2 \mathrm{Al}_{2} \mathrm{SiO}_{5}=3 \mathrm{BeAl}_{2} \mathrm{O}_{4}+8 \mathrm{SiO}_{2} \\
& \text { berilo sillimanita crisoberilo quartzo } \\
& \mathrm{Be}_{3} \mathrm{Al}_{2} \mathrm{Si}_{6} \mathrm{O}_{18}+3 \mathrm{Al}_{2} \mathrm{O}_{3}=3 \mathrm{BeAl}_{2} \mathrm{O}_{4}+\mathrm{Al}_{2} \mathrm{SiO}_{5}+5 \mathrm{SiO}_{2} \\
& \text { berilo solução crisoberilo sillimanita quartzo } \\
& \text { aluminosa }
\end{aligned}
$$


Na primeira reação, sillimanita é consumida e tida como evidência de contaminação por $\mathrm{Al}_{2} \mathrm{O}_{3}$, enquanto a segunda reação ocorre em pegmatitos graníticos "normais" submetidos a um estágio hidrotermal aluminoso tardio.

Origem semelhante é admitida por Franz \& Morteani (1984) que, com base em resultados experimentais e em cuidadosas observações petrográficas, interpretam a origem da associação crisoberilo + quartzo como metamórfica póspegmatítica, resultante da reação entre berilo e uma fase aluminosilicatada (feldspato) em regime de pressão e temperatura próximos à anatexia.

Por outro lado, Soman \& Nair (1985), apoiados sobre seus estudos em pegmatitos de Kerala, Índia, atribuem a origem do crisoberilo à cristalização no início do estágio pegmatítico a partir de uma fusão residual altamente aluminosa, com baixa solubilidade de silica resultante da presença de $\mathrm{CO}_{2}$.

Os autores atribuem esses corpos pegamtíticos à classe dos pegmatitos abissais ou de máxima profundidade, geralmente associados a processos de anatexia. Torna-se evidente que, independente da origem admitida pelos diferentes autores, a formação do crisoberilo parece exigir condições elevadas de P e T.

Já a cristalização da alexandrita e também da esmeralda, respectivamente as variedades do crisoberilo e berilo que contém $\mathrm{Cr}$ como agente cromóforo, é possivel somente em ambientes geológicos muito particulares onde foi possivel a interação entre $\mathrm{Be}$ e $\mathrm{Cr}$, elementos de comportamento geoquímico oposto.

Segundo alguns autores (Martin-lzard et al. 1995, dentre outros), depósitos de esmeralda e alexandrita são formados quando soluções ricas em $\mathrm{Be}$, provenientes de corpos graníticos ou pegmatíticos, percolam rochas ultramáficas que atuam, neste caso, como a fonte do $\mathrm{Cr}$. Tais depósitos, denominados por alguns autores de tipo xisto (Sinkankas 1981), resultam do desenvolvimento de uma borda de reação (black wall) geralmente clorítica ou flogopítica entre um veio pegmatítico e sua encaixante ultramáfica. A rocha resultante, de composição bastante peculiar, tem sido também denominada de glimmerito (Zabolotnaya 1977) ou sludito (Cassedanne 1991).

Outros autores, no entanto, sustentam também uma origem metamórfica, onde a atuação de processos metamórficos regionais sobre rochas previamente enriquecidas em $\mathrm{Be}$ e $\mathrm{Cr}$, dispostas lado a lado, é responsável pelo crescimento de porfiroblastos de esmeralda e/ou alexandrita, metamórficos portanto, e não 
magmáticos (Grundmann \& Morteani 1989, 1993, 1998, Morteani \& Grundmann 1977, dentre outros).

\section{X.B. Trabalhos Experimentais}

Informações sobre as condições de formação do crisoberilo podem ser obtidas a partir de estudos envolvendo os óxidos $\mathrm{BeO}-\mathrm{Al}_{2} \mathrm{O}_{3}-\mathrm{SiO}_{2}-\mathrm{H}_{2} \mathrm{O}$ (BASH).

Deve-se a Burt (1978) a primeira tentativa de reunir dados até então existentes (assembléias naturais e resultados experimentais) para a visualização do aspecto geral dos campos de estabilidade dos sete minerais mais comuns do sistema BASH: crisoberilo, fenacita, euclásio, bertrandita, berilo, caolinita e quartzo.

$\mathrm{Na}$ figura X.1 encontra-se representada em diagrama PXT a topologia derivada pelo autor.

Observa-se que a associação crisoberilo+quartzo, freqüentemente descrita em pegmatitos (Heinrich \& Buchi 1969, Soman \& Druzhinin 1987, Franz \& Morteani 1984), apresenta um amplo intervalo de temperatura e pressão, sendo ocasionalmente substituída por berilo + caolinita ou euclásio + caolinita em reações de hidratação (curvas (1) e (2) da figura X.1).

O sistema BASH também foi investigado por Franz \& Morteani (1981), que realizaram experimentos de síntese hidrotermal no intervalo entre 1 e $6 \mathrm{~kb}$ e 400 e $800^{\circ} \mathrm{C}$ com o objetivo de determinar o campo de estabilidade dos minerais euclásio e berilo. As relações de fases deduzidas pelos autores a partir de dados experimentais e cálculos termodinâmicos são apresentadas no diagrama PXT da figura X.2.

Em oposição à topologia derivada por Burt (1978), os resultados de Franz \& Morteani (1981) indicam a estabilidade da associação crisoberilo + quartzo somente a pressões elevadas, acima de 4 e $5 \mathrm{kbar}$ (curva (1) da figura X.2).

Barton (1986) realizou a série de experimentos mais abrangente no sistema BASH que, acrescidos de dados termodinâmicos, resultaram na grade petrogenética apresentada na figura X.3. Nesse diagrama PXT, os campos de estabilidade de fases importantes, como berilo e euclásio, e associações de ocorrência muito freqüente, como crisoberilo + quartzo, estão já bem delimitados. 


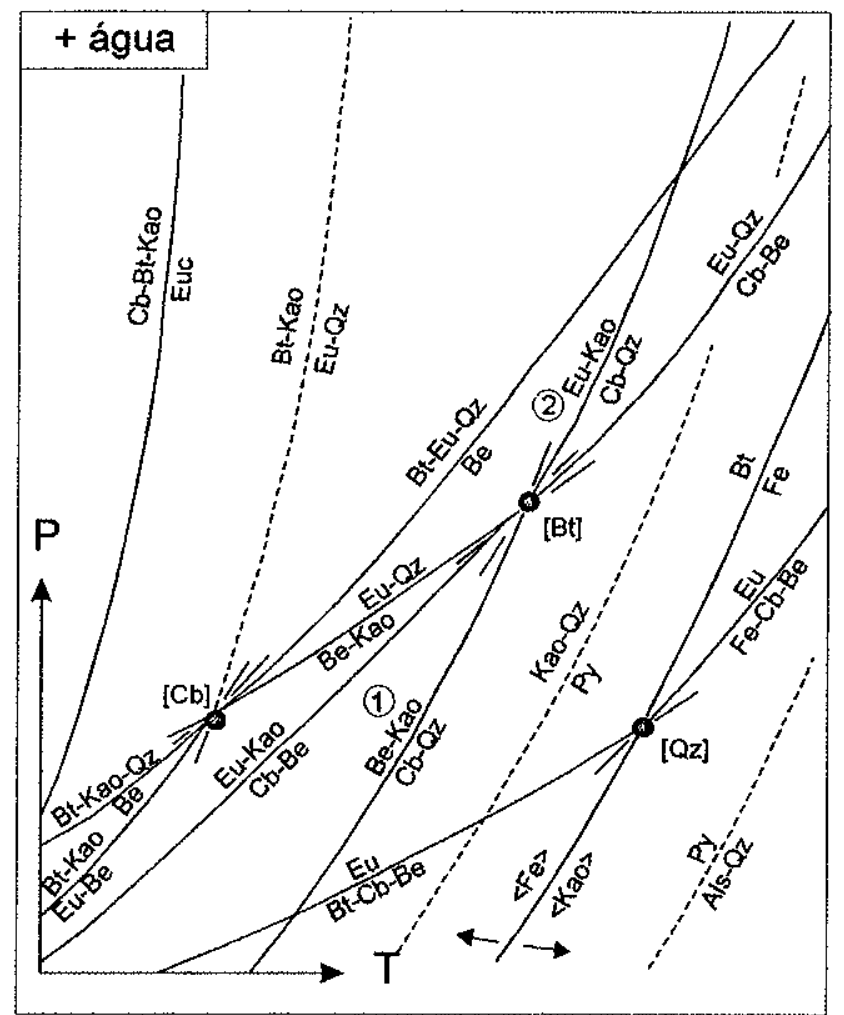

Fig.X.1: Representação esquemática em diagrama PXT (fluido presente) das relações entre os minerais mais comuns do sistema BASH. (Burt 1978).

Als: aluminossilicato; And: andaluzita; $\mathrm{Be}$ : berilo; $\mathrm{Br}$ : bromelita; $\mathrm{Bt}$ : bertrandita; $\mathrm{Cb}$ : crisoberilo; $\mathrm{Co}$ : corindon; Di: diásporo; Eu: euclásio; Fe: fenacita; Kao: caolinita; Ky: cianita; Py: pirofilita; Qz: quartzo; Sil: sillimanita; W: água.

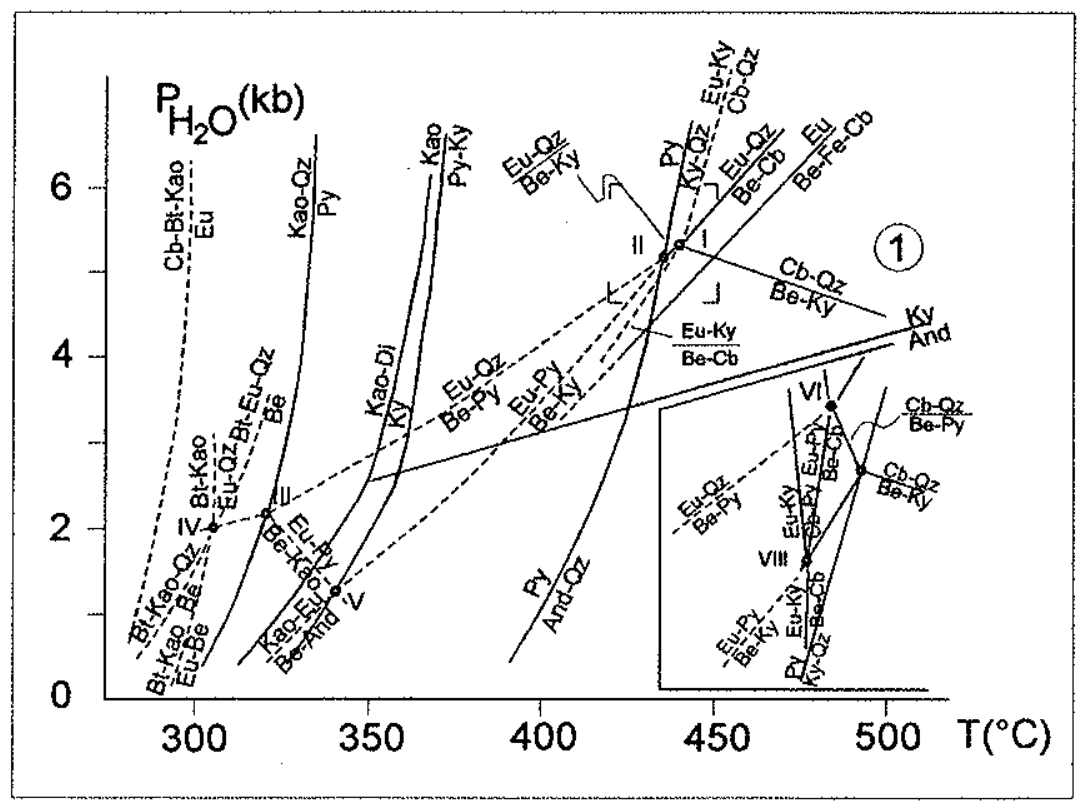

Fig.X.2: Relações de fases no sistema BASH (Franz \& Morteani 1981).

Linhas tracejadas: curvas de equilibrio hipotéticas; (1): reação de substituição do berilo $(\mathrm{Be}+\mathrm{Ky}=$ $\mathrm{Cb}+\mathrm{Qz})$.

Abreviaçöes como na figura X.1. 
Segundo os resultados do autor, o berilo apresenta um campo de estabilidade muito amplo, cujo limite inferior estende-se até aproximadamente $230^{\circ} \mathrm{C}$ e é representado pelas reaçöes de hidratação (Be+Water) (1) e (2) da figura X.3. No limite superior, seu consumo dá-se através da reação com aluminossilicato para a formação da associação crisoberilo+quartzo (curva (8)), definindo uma temperatura mínima em torno de $680^{\circ} \mathrm{C}$ para esse par de minerais.

A temperaturas mais baixas, euclásio torna-se estável (curva (7)), substituindo berilo ou crisoberilo em associações portadoras de aluminossilicatos (curvas (3), (4) e (5)). Berilo e crisoberilo coexistem em equilíbrio até aproximadamente $400^{\circ} \mathrm{C}$, sendo substituídos a temperaturas mais baixas por euclásio+aluminossilicato (curva (6).

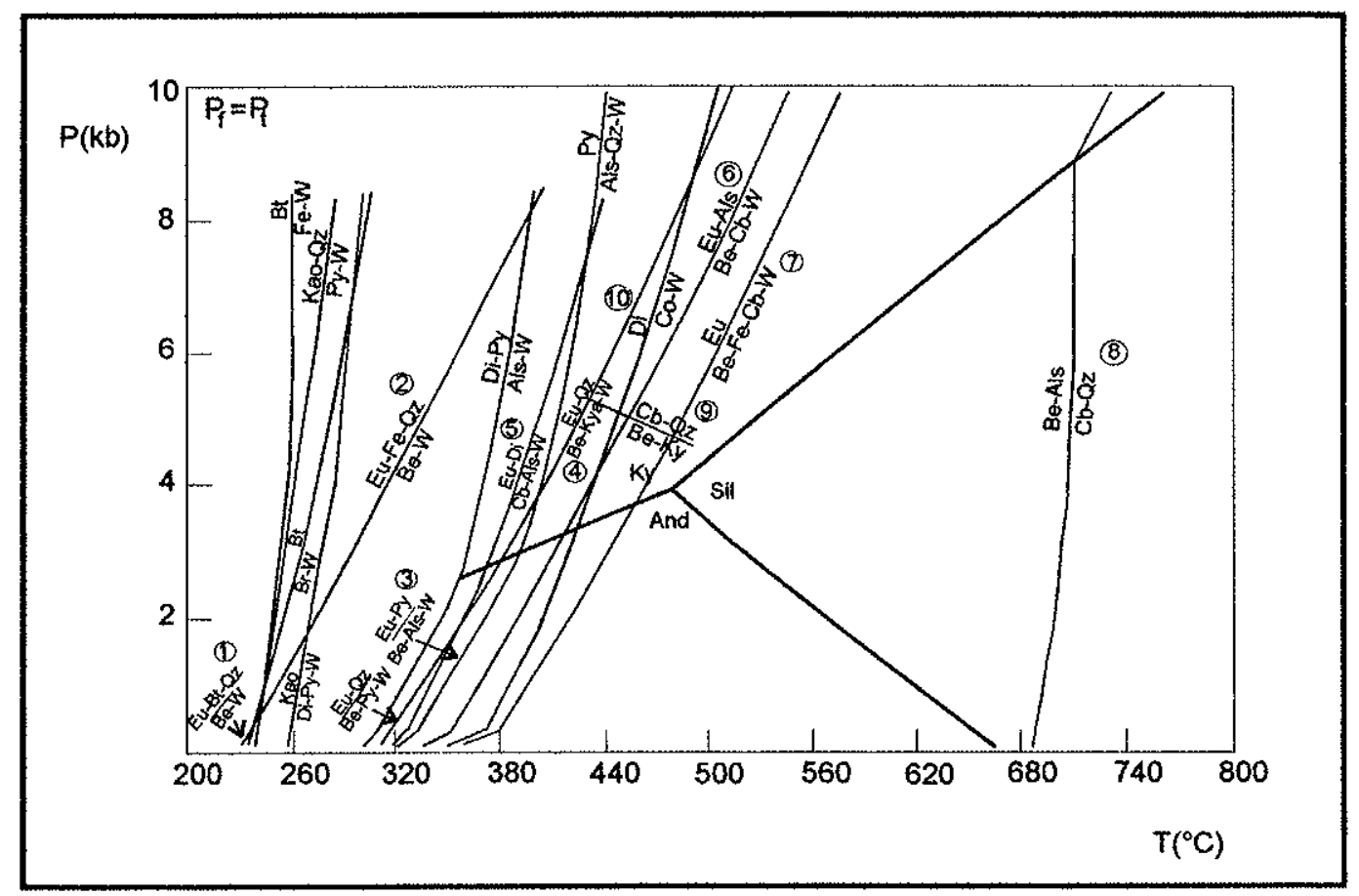

Fig.X.3: Relações de fases no sistema BASH (Barton 1986).

(1) e (2): limite inferior de estabilidade do berilo (reações de hiddrataçăo).

(3) e (4): limite inferior de estabilidade da associação berilo+aluminossilicato.

(5): limite inferior de estabilidade da associação crisoberilo+aluminossilicato.

(6): limite inferior de estabilidade da associaçăo crisoberilo+berilo.

(7): limite superior de estabilidade do euclásio.

(8): limite inferior de estabilidade da associação crisoberilo+quartzo.

(9): limite inferior de estabilidade da associação crisoberilo+quartzo segundo Franz \& Morteani (1981).

Abreviações como na figura X.1. 
Barton (1986) enfatiza ainda a utilidade dos minerais beriliferos como indicadores da atividade de alumina, sílica e água principalmente em ambientes metassomáticos, onde potenciais químicos são impostos externamente.

A partir dos resultados de experimentos de síntese a $1 \mathrm{~kb}$ em presença de fluido aquoso contendo sílica em concentrações variadas, o autor investigou então a estabilidade dos minerais beriliferos em relação a temperatura e atividade de sílica, construindo o diagrama $\log m_{\mathrm{H} 4 \mathrm{SiO}} \times \mathrm{T}$ da figura $\mathrm{X} .4$.

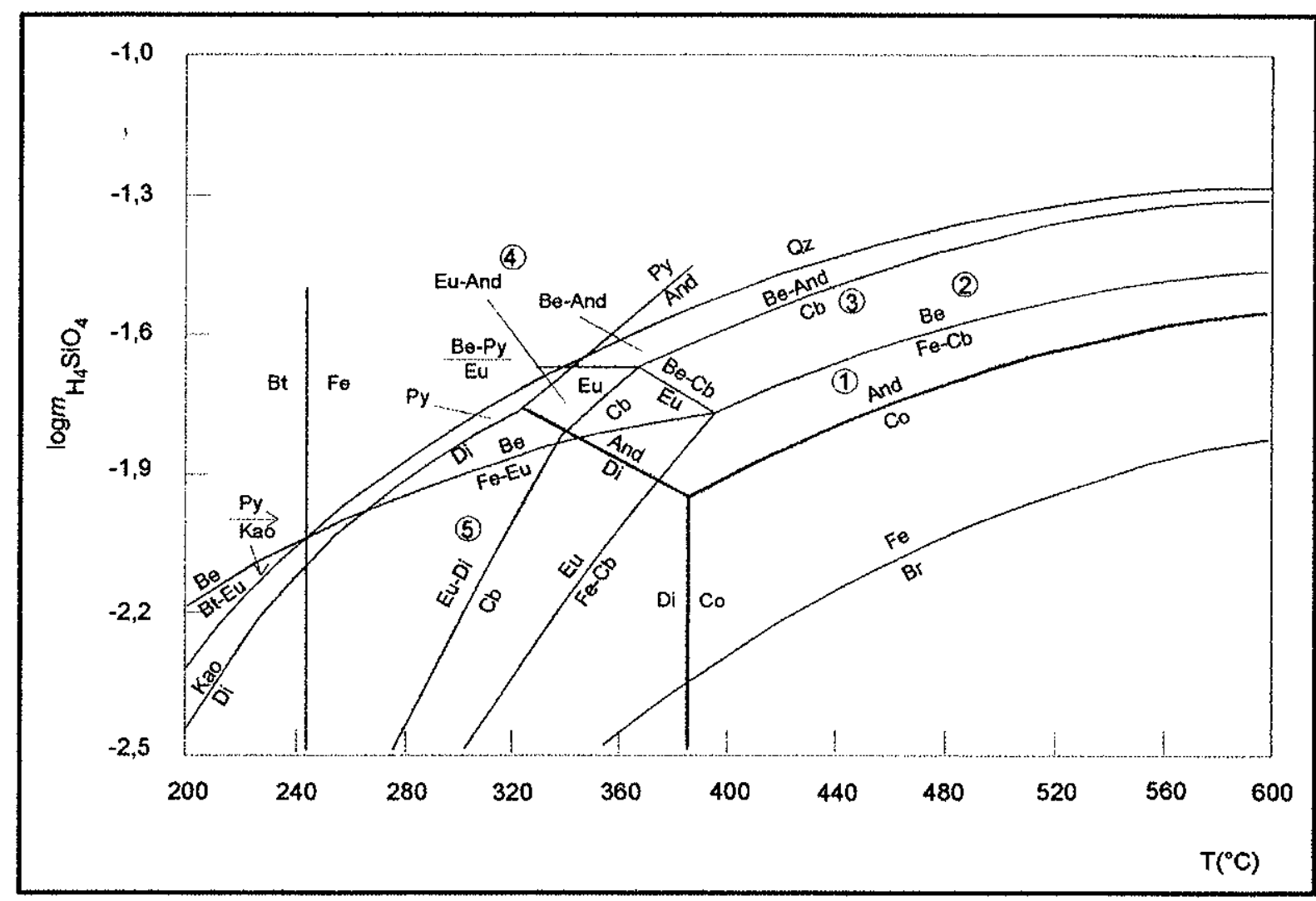

Fig.X.4: Projeção das relações de fases no sistema BASH a $1 \mathrm{~kb}$ em diagrama $\log m_{H 4 S i O 4} \times T$ (Barton 1986). m:molalidade da solução; $\mathrm{H}_{4} \mathrm{SiO}_{4}$ : presumivelmente a espécie mais comum em solução.

Abreviações como na figura X.1.

Analisando-se o diagrama acima mencionado, é possível verificar a incompatibilidade entre coríndon e berilo (curvas (1) e (2) e os limites do campo de estabilidade do crisoberilo dados pelas reações (3), (4) e (5). Nota-se ainda que berilo e crisoberilo podem ser compativeis em um intervalo estreito de atividade de sílica, 
definido pelas curvas (2) - surgimento de berilo com aumento na disponibilidade de sílica - e (3) - desaparecimento do crisoberilo.

Além desses trabalhos enfatizando as relações de equilíbrio entre os minerais beriliferos, citam-se também aqueles dedicados à investigação do processo de transporte do elemento Be.

Beus et al. (1963) realizaram trabalhos experimentais para investigar o comportamento do elemento Be no desenvolvimento de soluçöes pós-magmáticas de alta temperatura, e concluiram que a mobilidade do elemento dá-se através da formação de complexos, principalmente com flúor.

A formação de complexos com $\mathrm{CO}_{2}$ também é possível, após o consumo de flúor (Govorov \& Stunzhas 1963).

\section{X.C. Gênese do Crisoberilo das Lavras de Esmeraldas de Ferros e Hematita}

$\mathrm{Na}$ grande maioria das ocorrências descritas na literatura, a presença da alexandrita é atribuída à interação entre fluidos ricos em $\mathrm{Be}$ e rochas metaultramáficas (p. ex. Gübelin 1976, Martin-Izard et al. 1995, Grundmann \& Morteani 1998).

Embora pequenos corpos de rochas metaultramáficas estejam presentes na região, como nas mineralizações de esmeraldas de Córrego das Pedras e Limeira, na área de Esmeraldas de Ferros aqueles ainda não foram localizados, surgindo portanto a questão relativa à origem do $\mathrm{Cr}$ incorporado à variedade alexandrita.

A migração a partir de corpos não aflorantes até os pontos de nucleação e cristalização da alexandrita não parece muito provável, uma vez que $\circ \mathrm{Cr}$ é considerado por muitos autores um elemento imóvel (Curtis \& Brown 1969, 1971, Sanford 1982).

Segundo relatos de Felber (1991), sedimentos ricos em matéria orgânica podem apresentar concentrações de $\mathrm{Cr}$, que permanece incorporado à estrutura da biotita durante o metamorfismo.

Pode-se considerar portanto o biotita xisto grafitoso como a fonte do elemento, sendo $\circ \mathrm{Be}$ proveniente das rochas graníticas e gnáissicas, tanto $\mathrm{O}$ 
Ortognaisse Açucena quanto o Gnaisse Monlevade, que se mostram enriquecidos no elemento (Fig.VI.4).

A ocorrência de Esmeraldas de Ferros, investigada neste trabalho, apresenta portanto uma associação raramente descrita, onde cristais da variedade alexandrita do crisoberilo são formados pela percolação de fluidos ricos em $\mathrm{Be}$ através de uma rocha metassedimentar, o biotita xisto grafitoso pertencente à unidade denominada Gnaisse Monlevade.

A outra única ocorrência de alexandrita em rochas metassedimentares de que se tem conhecimento foi descrita por Petersen Jr (1998) também no Brasil, no Município de Minaçu, Goiás.

As condições sob as quais desenvolveu-se o processo genético acima descrito podem ainda ser estimadas com base em informações sobre a geologia regional, dados microtermométricos e estabilidade dos minerais beriliferos.

Em Esmeraldas de Ferros, os niveis mineralizados apresentam atitude concordante com a rocha encaixante, o Gnaisse Monlevade, que deve seu principal metamorfismo e estruturação ao Evento pós-Minas/Espinhaço, de idade proterozóica inferior (Schorscher 1992).

Considerando-se a isócora obtida para as inclusões fluidas carbônicas em veio de quartzo e a estabilidade da associação crisoberilo + quartzo (identificado como inclusões singenéticas na alexandrita) determinada por Barton (1986), obtémse temperatura de $700^{\circ} \mathrm{C}$ e pressão em torno de $5,5 \mathrm{kbar}$ para a formação da alexandrita de Esmeraldas de Ferros (Fig.X.5).

Esses valores, aparentemente muito elevados, representam provavelmente o pico do metamorfismo e encontram-se em acordo com resultados geotermobarométricos obtidos por Rettinger et al. (1996), temperatura em torno de $640^{\circ} \mathrm{C}$ e pressão entre 5,5 e $6,0 \mathrm{kbar}$.

No entanto, é possivel que a formação da alexandrita tenha realmente ocorrido nas condições acima descritas, uma vez que tanto trabalhos experimentais (Franz \& Morteani 1984) quanto evidências de campo (Soman \& Nair 1985) sugerem a estabilidade do mineral em condições próximas à anatexia.

Nesse regime metamórfico elevado, é provável que os fluidos presentes tenham sido constituídos predominantemente por $\mathrm{CO}_{2}$, aprisionado como inclusões fluidas de alta densidade em veios de quartzo. 


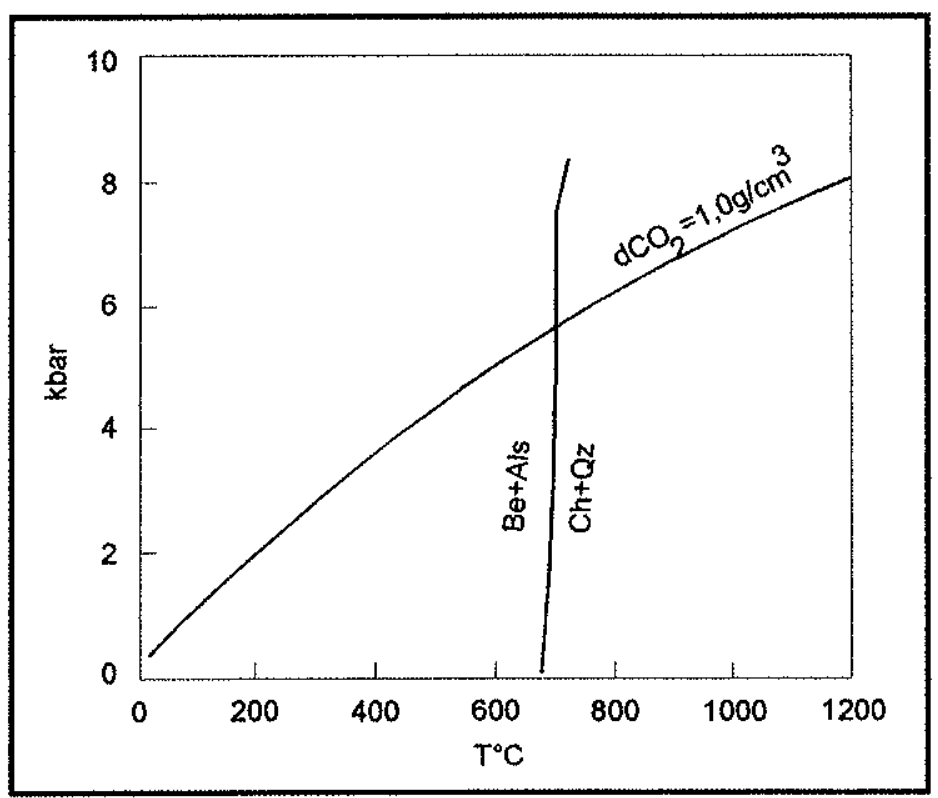

Fig.X.5: Estabilidade da associação crisoberilo + quartzo (Barton 1986) e isócora para inclusões fluidas carbônicas em veio de quartzo da Lavra de Hematita $\left(d=1,00 \mathrm{~g} / \mathrm{cm}^{3}\right)$.

A presença do $\mathrm{CO}_{2}$ teria um duplo papel na mineralização: servir como meio de transporte para o Be, na forma de complexos (Govorov \& Stunzhas 1963), e reduzir a atividade de sílica, favorecendo a precipitação de crisoberilo em lugar de berilo (Fig.X.4).

Segundo os dados da isotopia de $\mathrm{C}$, esse fluido teria sua origem na hidrólise de matéria orgânica e em reações de decomposição de sedimentos carbonáticos.

Quanto à alexandrita de Hematita, sua natureza aluvionar impede o exato conhecimento de seu ambiente de formação, permitindo apenas suposições com base em suas caracteísticas mineralógicas e na geologia do depósito.

Em comparação com a alexandrita de Esmeraldas de Ferros, o material de Hematita apresenta características muito mais condizentes com um ambiente de formação pegmatítico, tais como maior dimensão e pureza dos cristais (menor fraturamento, menor quantidade de inclusões), aliado ainda à presença, no aluvião, de crisoberilo amarelo, um mineral típico de pegmatitos.

A presença de rochas metaultramáficas portadoras de esmeraldas nas proximidades de Hematita (Córrego das Pedras e Limeira) sugere a atuação de 
processo semelhante ao descrito por Machado $(1994,1998)$ para as esmeraldas de Capoeirana e Belmont. No entanto alexandritas associadas a rochas metaultramáficas apresentam invariavelmente inclusões de minerais típicos dessas litologias, como flogopita e actinolita (Gübelin 1976, Henn 1985), fato que não foi observado neste trabalho ou mesmo por outros autores que investigaram material proveniente de Hematita (Bank et al. 1987).

\section{CONSIDERAÇÕES FINAIS}

Neste estudo, foram tratados os aspectos genéticos das ocorrências de crisoberilo, variedade alexandrita, da região entre Nova Era e Ferros.

Apesar das dificuldades impostas pela natureza aluvionar ou pelo alto grau de alteração dos depósitos, conclusões sobre a gênese do material puderam ser construídas a partir da integração de dados obtidos de ocorrências de esmeraldas (Córrego das Pedras e Limeira) e também a partir da vasta literatura geológica existente sobre a região.

Anomalias de $\mathrm{Be}$, detectadas não apenas nas rochas metaultramáficas diretamente envolvidas naquelas mineralizações de esmeralda como também em rochas do Ortognaisse Açucena e Gnaisse Monlevade, atestam a especialização da região, confirmada pelas ocorrências já descritas de esmeralda (Souza 1988, Machado 1994, 1998) e água-marinha (Marciano 1995).

No tocante às mineralizações em esmeralda e alexandrita, é evidente sua associação, ao menos espacial, com o Granito Borrachudos e seu equivalente, o Ortognaisse Açucena. Nas áreas de produção de esmeraldas de Capoeirana e Belmont, onde o Granito Borrachudos encontra-se menos afetado por processos metamórficos posteriores, seu relacionamento genético com as mineralizações beriliferas é reconhecido por Machado $(1994,1998)$, que atribui a origem de ambos a processos metassomáticos causados pela circulação de fluidos ricos em álcalis através de zonas de cisalhamento profundas.

Nas áreas de domínio do Ortognaisse Açucena, o maior retrabalhamento desta unidade dificulta tais associações, fazendo-se necessário primeiramente um trabalho mais abrangente de reconhecimento das relaçöes entre 0 Granito 
Borrachudos em suas áreas-tipo e as demais rochas granitóides incluídas na Suíte Borrachudos.

O modelo genético resultante deste trabalho de integração deve portanto compatibilizar informaçōes e interpretações até o momento conflitantes, como a idade dessas rochas e sua natureza.

O resultado da aplicação do método da tipologia do zircão (Pupin 1980) à fração pesada da Lavra de Hematita, sugerindo uma fonte a partir de sienitos e granitos alcalinos a peralcalinos, ressalta mais uma vez a controvérsia quanto à natureza do Granito Borrachudos (Dorr \& Barbosa 1963, Schorscher 1992) e conseqüentemente do Ortognaisse Açucena.

\section{REFERÊNCIAS BIBLIOGRÁFICAS}

ALKMIM, F. F.; MARSHAK, S. 1998. Transamazonian Orogeny in the Southern São Francisco Craton Region, Minas Gerais, Brazil: evidence for Paleoproterozoic collision and collapse in the Quadrilátero Ferrifero. Precambrian Res., 90:2958.

ALMEIDA, F. F. M. 1977. O Cráton do São Francisco. Rev. Bras. Geoc., 7(4):349364.

ANDERSON, B. W. 1980. Gem testing. Butterworths, London, 9th ed., 434p.

ATENCIO, D. 1999. Memória da Mineralogia Brasileira. Tese para concurso de LivreDocência, IG-USP, $214 p$ (inédito).

BAKKER, R. J.; JANSEN, B. H. 1991. Experimental post-entrapment water loss from synthetic $\mathrm{CO}_{2}-\mathrm{H}_{2} \mathrm{O}$ inclusions in natural quartz. Geochim. Cosmoch. Acta, 55:2215-2230. 
BAKKER, R. J.; JANSEN, B. H. 1994. A mechanism for preferential $\mathrm{H}_{2} \mathrm{O}$ leakage from fluid inclusions in quartz, based on TEM observations. Contrib. Mineral. Petrol., 116:7-20.

BANK, F. H.; BANK, H.; GÜBELIN, E.; HENN, U. 1987. Alexandrite von einem neuen Vorkommen bei Hematita in Minas Gerais, Brasilien. Zeitschrift der Deutschen Gemmologischen Gesellschaft, 36:121-131.

BARBOSA, M. P. 1988. Estudo do relacionamento genético de feições geologicas do Espinhaço Meridional e adjacências (MG). Tese de doutorado, IG-USP, vol. I e II, 237p., 30 anexos (inédito).

BARTON, M. D. 1986. Phase equilibria and thermodynamic properties of minerals in the $\mathrm{BeO}-\mathrm{Al}_{2} \mathrm{O}_{3}-\mathrm{SiO}_{2}-\mathrm{H}_{2} \mathrm{O}(\mathrm{BASH})$ system, with petrologic applications. Am. Mineral., 71(3/4):277-300.

BAUERHANSL, P.; BERAN, A. 1997. Trace Hydrogen in the olivine-type minerals chrysoberyl, $\mathrm{Al}_{2} \mathrm{BeO}_{4}$ and sinhalite, $\mathrm{MgalBO}_{4}$ - a polarized FTIR spectroscopic study. Schweiz. Mineral. Petrogr. Mitt., 77:131-136.

BEST, M. G. 1982. Igneous and Metamorphic Petrology. W. H. Freeman \& Co., New York, 630p.

BEUS, A. A.; SOBOLEV, B. P.; DIKOV, Y. P. 1963. Geochemistry of beryllium in high temperature postmagmatic mineralization. Geochemistry, 3:316-323 (1963).

BILAL, E.; MARCIANO, V. R. P. R. O.; FUZIKAWA, K.; CORREIA NEVES, J. M.; GIRET, A. 1995. Datação de monazitas do Distrito Pegmatítico de Santa Maria de Itabira, Minas Gerais. In: SIMP. GEOL. MINAS GERAIS, 9, Diamantina. Anais ..., SBG - Núcleo MG, Bol. 13:46-47. 
BOZKURT, E.; PARK, R. G. 1997. Microstructures of deformed grains in the augen gneiss of southern Menderes Massif (Western Turkey) and their tectonic significance. Geol. Rundsch., 86:103-119.

BOTTINGA, Y. 1969. Calculated fractionation factors for carbon and hydrogen isotope exchange in the system clacite - carbon dioxide - graphite - methane - hydrogen - water. Geochim. Cosmoschim. Acta, 33:49-64.

BRAGG, W. L.; BROWN, G. B. 1926. Die Kristallstruktur von Chrysoberyll $\left(\mathrm{BeAl}_{2} \mathrm{O}_{4}\right)$. Zeitschrift für Kristallographie, 63:122-143.

BUCHER, K.; FREY, M. 1994. Petrogenesis of Metamorphic Rocks. Springer-Verlag, Berlin Heidelberg. $6^{\text {th }}$ ed., 318p.

BUKIN, G. V.; MATROSOV, V. N.; OREKHOVA, V. P.; REMIGAILO, Y. L.; SEVASTYANOV, B. K.; SYOMIN, E. G.; SOLNTSEV, V. P.; TSVETKOV, E. G. 1981. Growth of alexandrite crystals and investigation of their properties. Journ. Crystal Growth, 52:537-541.

BURNS, R. G. 1993. Mineralogical Applications of Crystal Field Theory. $2^{\text {nd }}$ ed. Cambridge, Cambridge University Press. 551p.

BURT, D. M. 1978. Multisystems analysis of berylliummineral stabilities: the system $\mathrm{BeO}-\mathrm{Al}_{2} \mathrm{O}_{3}-\mathrm{SiO}_{2}-\mathrm{H}_{2} \mathrm{O}$. Amer. Mineral., 63:664-676.

CASSEDANNE, J. P. 1991. Tipologia das jazidas brasileiras de gemas. In: SCHOBBENHAUS, C.; QUEIROZ, E. T.; COELHO, C. E. S. (coord.): Principais depósitos minerais do Brasil. Volume IV - Parte A: Gemas e rochas ornamentais. DNPM-CPRM, Brasília, p.17-5.

CASSEDANNE, J.; RODITI, M. 1993. The location, geology, mineralogy and gem deposits of alexandrite, cat's-eye and chrysoberyl in Brazil. Journal of Gemmology, 23(6):333-355. 
CHEMALE Jr., F. 1987. Gênese das rochas graníticas do tipo Borrachudos. In: CONGR. BRAS. GEOQUIMICA, Porto Alegre, Anais... Soc. Bras. Geol., vol.I:171-186.

CLINE, C. F.; PATTERSON, D. A. 1973. Synthetic crystal and method of making same. United States patent 3,912,521, filed April 30, 1973, issued October 14, 1975.

CORDIER, P.; DOUKHAN, J. C.; RAMBOZ, C. 1994. Influence of dislocations on water leakage from fluid inclusions in quartz: a quantitative reappraisal. Eur. J. Mineral., 6:745-752.

CURTIS, C. D.; BROWN, P. E. 1969. The metasomatic development of zoned ultrabasic bodies in Unst, Shetland. Contrib. Mineral. Petrol., 24:275-292.

CURTIS, C. D.; BROWN, P. E. 1971. Trace element behaviour in the zoned metasomatic bodies of Unst, Shetland. Contrib. Mineral. Petrol., 31:87-93.

DIRLAM, D. M.; MISIOROWSKI, E. B.; TOZER, R.; STARK, K. B.; BASSETT, A. M. 1992. Gem wealth of Tanzania. Gems \& Gemology, 28(2):80-102.

DORR, J. N.; BARBOSA, A. L. M. 1963. Geology and ore deposits of the Itabira District, Minas Gerais, Brazil. U. S. Geol. Sun. Prof. Pap., 341-C, 110p.

DORR, J. V. N.; HERZ, N.; BARBOSA, A. L. M.; SIMMONS, G. C. 1960. Esboço Geológico do Quadrilátero Ferrifero de Minas Gerais, Brasil. Dept. Nac. Produção Mineral, Public. Especial 1, 120p. Rio de Janeiro.

DOSSIN, I. A.; DOSSIN, T. M.; CHARVET, J.; COCHERIE, A.; ROSSI, P. 1993. Single-zircon dating by step-wise Pb-evaporation of middle proterozoic magmatism in the Espinhaço Range, Southeastern São Francisco Craton (Minas Gerais, Brazil). In: SIMP. CRATON DO SÃO FRANCISCO, 2. Salvador, 1993. Anais ..., p.39-42. 
DRUMOND, J. B. V. 1985. Projeto Mapas Metalogenéticos e de Previsão de Recursos Minerais. Folha Ipatinga - Texto e Mapas. DNPM/CPRM, 24p.

DUSSIN, T. M. 1994. Associations volcano-plutoniques de I"Espinhaço Meridional (SE - Bresil). Un exemple d'évolution de la croûte proterozoïque.Tese de Doutorado, Université d'Orléans, 177p. (Inédito).

EL BOUSEILY, A. M.; EL SOKKARY, A. A. 1975. The relation between Rb, Ba and $\mathrm{Sr}$ in granitic rocks. Chemical Geology, 16:207-219.

EMERY, D.; ROBINSON, A. 1993. Inorganic Geochemistry - Applications to Petroleum Geology. Oxford, Blackwell Scientific Publications. 254p.

FARRELL, E. F.; NEWHAM, R. E. 1965. Crystal-field spectra of chrysoberyl, alexandrite, peridot, and sinhalite. Amer. Mineral., 50(11/12):1972-1981.

FARRELL, E. F.; FANG, J. H.; NEWNHAM, R. E. 1963. Refinement of the chrysoberyl structure. Am. Mineral., 48(7/8):804-810.

FELBER, J. 1991. Petrographische und geochemische Untersuchungen an graphifführenden Metamorphiten der Kropfmühl-Serie im Passauer Wald. Geologica Bavarica, 96:51-67.

FERNANDES, M. L. S.; MARCIANO, V. R. P. R. O.; OLIVEIRA, R. C.; CORREIA NEVES, J. M.; DILÁSCIO, M. V. 1994. Granitos Borrachudos: um exemplo de granitogênese anorogênica na porção central do Estado de Minas Gerais. Geonomos, 2(2):23-29.

FERNANDES, M. L. S.; CORREIA NEVES, J. M.; GIRET, A.; COSTA, K. V. 1995. Estimativa das condições de cristalização do Granito Borrachudos na região de Dores de Guanhães, MG. In: SIMP. GEOL. MINAS GERAIS, 8, Diamantina. Anais ..., SBG - núcleo MG, Bol. 13:64-66. 
FIGUEIRAS, J.; WAERENBORGH, J. C. 1997. Fully oxidized chromite in the Serra Alta (South Portugal) quartzites: chemical and structural characterization and geological implications. Mineralogical Magazine, 61:627-638.

FOLHA DE SÃO PAULO. 1996. Mistérios cercam produção de pedra rara: governo brasileiro não fiscaliza a extração da alexandrita, mineral cujo preço é maior que o do diamante. folha de São Paulo, 8 de abril de 1996.

FRANZ, G.; MORTEANI, G. 1981. The system BeO-Al $\mathrm{O}_{3}-\mathrm{SiO}_{2}-\mathrm{H}_{2} \mathrm{O}$ : Hydrothermal investigation of the stability of beryl and euclase in the range from 1 to $6 \mathrm{~kb}$ and 400 to $800^{\circ} \mathrm{C}$. N. Jb. Miner. Abh., 140(3):273-299.

FRANZ, G.; MORTEANI, G. 1984. The formation of chrysoberil in metamorphosed pegmatites. Journ. Petrol., 25(1): 27-52.

FRITSCH, E.; ROSSMAN, G. R. 1987. An update on color in gems. Part 1: introduction and colors caused by dispersed metal ions. Gems \& Gemology, 23(3):126-139.

FRITSCH, E.; STOCKTON, C. M. 1987. Infrared spectroscopy in gem identification. Gems \& Gemology, 23(1):18-26.

FRYER, C. W. 1993. Gem trade lab notes: Synthetic alexandrite with needle-like inclusions. Gems \& Gemology, 29(1):46.

GAAL, R. A. P. 1976/77. Cathodoluminescence of gem materials. Gems \& Gemology, 15:238-244.

GOVOROV, I. N.; STUNZHAS, A. A. 1963. Mode of transport of beryllium in alkali metasomatism. Geochemistry, 4:402-409.

GROSSI SAD, J. H.; CHIOD Filho, C.; SANTOS, J. F.; MAGALHÃES, J. M.; CARELOS, P. M. 1990. Duas suites graníticas do bordo sudeste do Craton 
Sanfranciscano, em Minas Gerais: petroquímica e potencial metalogenético. In: CONGR. BRAS. GEOL., 36, Natal, 1990. Anais ... Natal, SBG, v.4, p. 1836-1848.

GRUNDMANN, G.; MORTEANI, G. 1989. Emerald mineralization during regional metamorphism: the Habachtal (Austria) and Leydsdorp (Transvaal, South Africa) deposits. Econ. Geol., 84:1835-1849.

GRUNDMANN, G.; MORTEANI, G. 1993. Emerald formation during regional metamorphism: the Zabara, Sikeit and Umm Kabo deposits (Eastern Desert, Egypt). In: ULF THORWEIHE \& HEINZ SCHANDELMEIER (eds.) Geoscientific Research in Northeast Africa. Proceedings of the International confernce on Geoscientific Research in Northeast Africa, Berlin, Germany, 17-19 June 1993. A. A. Balkema, Rotterdam/Brookfield, pp.494498.

GRUNDMANN, G.; MORTEANI, G. 1998. Alexandrite, emerald, ruby, sapphire and topaz in a biotite-phlogopite fels from Poona, Cue District, western Australia. Australian Gemmologist, 20:159-167.

GUBELIN, E. J. 1976. Alexandrite from Lake Manyara, Tanzania. Gems \& Gemology, 15(7):203-209.

GUO, X.; CHEN, M.; LI, N.; QIN, Q.; HUANG, M.; FEI, J.; WEN, S.; LI, Z.; QIN, Y. 1987. Czochralski growth of alexandrite crystals and investigation of their defects. Joum. Crystal Growth, 83:311-318.

HALL, D. L.; STERNER, S. M. 1993. Preferential water loss from synthetic fluid inclusions. Contrib. Mineral. Petrol., 114:489-500.

HANMER, S. K. 1982. Microstructure and geochemistry of plagioclase and microcline in naturally deformed granite. Journ. Struct. Geology, 4(1):197-213. 
HEINRICH, E. W.; BUCHI, S. H. 1969. Beryl - Chrysoberyl - Sillimanite paragenesis in pegmatites. Indian Mineralogist, 10:1-7.

HENN, U. 1985. Vergleichende chemische und optische Untersuchungen an Chrysoberyllen verschiedener Lagerstätten. Tese de Doutorado, Johannes Gutenberg-Universität Mainz, 356p.

HENN, U. 1992. Uber die diagnostischen Merkmale von synthetischen Alexandriten aus der Gemeinschaft Unabhangiger Staater (GUS). Zeitschrift der Deutschen Gemmologischen Gesellschaft, 41(2/3):85-93.

HENN, U. 1995. Edelsteinkundliches Praktikum. Zeitschrift der Deutschen Gemmologischen Gesellschaft, 44(4):3-112.

HERZ, N. 1970. Gneissic and igneous rocks of the Quadrilátero Ferrifero, Minas Gerais, Brazil. U. S. Geol. Surv. Prof. Pap., 641-B, 58p.

HOEFS, J. 1997. Stable Isotope Geochemistry. Berlin, Springer-Verlag, $4^{\text {th }}$ ed. 201p.

HOEFS, J.; MORTEANI, G. 1979. The carbon isotopic composition of fluid inclusions in Alpine fissures quartzes from the western Tauern Window (Tyrol, Austria). N. Jb. Miner. Mh., 3:123-134.

HOEFS, Von J.; STALDER, H. A. 1977. Die C-Isotopenzusammensetzung von $\mathrm{CO}_{2-}$ haltigen Flüssigkeitseinschlüssen in Kluftquarzen der Zentralalpen. Schweiz. Mineral. Petrogr. Mitt., 57:329-347.

HOLLISTER, L. S. 1990. Enrichment of $\mathrm{CO}_{2}$ in fluid inclusions in quartz by removal of $\mathrm{H}_{2} \mathrm{O}$ during crystal-plastic deformation. Journ. Struct. Geol., 12(7):895-901.

HURLBUT Jr., C. S.; KAMMERLING, R. C. 1991. Gemology. John Wiley \& Sons, New York, $2^{\text {nd }}$ ed., 336p. 
ISOGAMI, M.; NAKATA, r. 1986. Chrysoberyl cat's eye synthetic single crystal. United States patent 4,621,065, filed September 21, 1984, issued November 4, 1986.

KANE, R. E. 1987. Inamori synthetic cat's-eye alexandrite. Gems \& Gemology, 23(3):158-162.

KARFUNKEL, J.; WEGNER, R. 1993. Das Alexandritvorkommen von Esmeraldas de Ferros, Minas Gerais, Brasilien. Zeitschrift der Deutschen Gemmologischen Gesellschaft, 42:7-15.

KING, J. M.; MOSES, T. M.; SHIGLEY, J. E.; LIU, Y. 1994. Color grading of colored diamonds in the GIA Gem Trade Laboratory. Gems \& Gemology, 30(4):220242.

KLEIN, C.; HURLBUT Jr., C. S. 1994. Manual of Mineralogy (after J. D. Dana). 21th edition, John Wiley \& Sons, 596p.

KREULEN, R. 1980. $\mathrm{CO}_{2}$-rich fluids during regional metamorphism on Naxos (Greece): carbon isotopes and fluid inclusions. Amer. Journ. Sci., 280:745771.

LUCKSCHEITER, B.; MORTEANI, G. 1980. Microthermometrical and chemical studies of fluid inclusions in minerals from Alpine veins from the penninic rocks of the central and western Tauern window (Austria/ltaly). Lithos, 13:6177.

MACHADO, G. A. A. 1994. Geologia da região e aspectos genéticos das jazidas de esmeralda de Capoeirana e Belmont, Nova Era - Itabira, MG. Dissertação de Mestrado. IG-USP, 134p. (Inédito). 
MACHADO, G. A. A. 1998. Jazidas de esmeralda de Capoeirana e Belmont - MG: Geologia, petrogênese e metalogênese. Tese de Doutoramento. IG-USP, 294p. (Inédito).

MACHIDA, H.; YOSHIHARA, Y. 1980. Synthetic single crystal for alexandrite gem. United States patent 4,240,834, filed September 14, 1979, issued December 23,1980 .

MANIAR, P. D.; PICCOLI, P. M. 1989. Tectonic discrimination of granitoids. Geol. Soc. Amer. Bull., 101:635-643.

MARCIANO, V. R. P. R. O. 1995. O Distrito Pegmatítico de Santa Maria de Itabira, MG. Mineralogia, Geoquímica e Zoneografia. Tese de Doutoramento. IGUSP, 216p. (Inédito).

MARCIANO, V. R. P. R. O.; SVISERO, D. P.; CORREIA NEVES, J. M. 1993. Dados geocronológicos de pegmatitos da borda oriental do Craton do São Francisco. In: SIMP. CRATON SÃO FRANCISCO, 2, Salvador. Anais ... SBG - Núcleo BAISE - SGM, p.362-363.

MARDER, J. M.; MITCHELL, T. E. 1982. The nature of precipitates in cat's-eye chrysoberyl. Proceedings... Electron Microscopy society of America, Annual Meeting, Washington, D. C., 40:556-557.

MARSHALL, D. J. 1988. Cathodoluminescence of geological materials. Boston, Unwin Hyman, 146p.

MARTIN-IZARD, A.; PANIAGUA, A.; MOREIRAS, D. 1995. Metasomatism at a granitic pegmatite-dunite contact in Galicia: the Franqueira occurrence of chrysoberyl (alexandrite), emerald and phenakite. Can. Mineral., 33(4):775792. 
McMILLAN, P. 1985. Vibrational Spectroscopy in the Mineral Sciences. In: KIEFFER, S. W.; NAVROTSKY, A. (ed.). Microscopic to Macroscopic: Atomic Environments to Mineral Themodynamics. Reviews in Mineralogy, 14:9-63.

MOHANTY, J. K.; SAHOO, R. K.; PAUL, A. K. 1996. Chromite alteration at BoulaNausahi Igneous Complex, Orissa. Journal Geological Society of India, 48(3):265-276.

MORRIS, R. C.; CLINE, C. F. 1976. Chromium doped beryllium aluminate lasers. United States patent 3,997,853, filed November 29, 1974, issued December 14, 1976.

MORTEANI. G.; GRUNDMANN, G. 1977. The emerald porphyroblasts in the penninic rocks of the central Tauern Window. N. Jb. Miner. Mh., 1977(11):509-516.

Munsell Book of Color. 1976. Glossy Finish Collection, vol. 1-2.

OHMOTO, H.; RYE, R. O. 1979. Isotopes of Sulfur and Carbon. In: BARNES, H. L. (ed.), Geochemistry of Hydrothermal Ore Deposits. John Wiley \& Sons, $2^{\text {nd }}$ ed., p. 509-567.

OTTEMANN, J.; SCHMETZER, K.; BANK, H. 1978. Neue Daten zur Anreicherung des Elements Gallium in Alexandriten. N. Jahrbuch Mineral., 1978:145-192.

PALACHE, C.; BERMAN, H.; FRONDEL, C. 1944. The system of mineralogy of James Dwight Dana and Edward Salisbury Dana. v.1: Elements, sulfides, sulfosalts, oxides. John Wiley \& Sons, New York, $7^{\text {th }}$ ed., $834 p$.

PEACOCK, M. A. 1931. Classification of igneous rock series. Journal of Geology, 39:54-67. 
PELTONEN, P. 1995. Crystallization and re-equilibration of zoned chromite in ultramafic cumulates, Vanmala Ni-Belt, Sowthwestern Finland. Can. Mineral., 33(3):521-535.

PETERSEN Jr., K. J. 1998. Alexandrita no Municipio de Minaçu, Goiás: Mineralogia, Geologia e Considerações Genéticas. Dissertação de Mestrado, IG-USP, 167p. (Inédito).

PETTIJOHN, F. J.; POTTER, P. E.; SIEVER, R. 1973. Sand and Sandstone. springer Verlag, New York.

PFLUG, R.; RENGER, F. 1973. Estratigrafia e evolução geológica da margem SE do Craton Sanfranciscano. In: CONGR. BRAS. GEOL., 27, Aracaju, 1973. Anais ..., Aracaju, SBG, v.2, p.5-19.

PINHEIRO, M. V. B.; BASÍLIO, M. S.; KRAMBOCK, K.; DANTAS, M. S. S.; PANIAGO, R.; ASSUNÇÃO, A. L.; PEDROSA-SOARES, A. C. 2000. The cause of colour of the blue alexandrites from Malacacheta, Minas Gerais, Brazil. J. Gemm., 27(3):161-170.

PONAHLO, J. 1993. Kathodolumineszenz (KL) und KL-Spektren von Edelsteinen. Z. Dt. Gemmol. Ges., 42(2/3):101-113.

PROCTOR, K. 1988. Chrysoberyl and alexandrite from the pegmatite districts of Minas Gerais, Brazil. Gems \& Gemology, 24(1):16-32.

PRYER, L. L. 1993. Microstructures in feldspars from a major crustal thrust zone: the Grenville Front, Ontario, Canada. J. Struct. Geol., 15(1):21-36.

PUPIN, J. P. 1980. Zircon and granite petrology. Contrib. Mineral. Petrol., 73:207220. 
RAO, A. B.; ADUSUMILLI, M. S.; CASTRO, C. 1996. Diagnostic characteristics of the aquamarine deposit of Canoas, Acari, Rio Grande do Norte State, Brasil. In: CONGR. BRAS. GEOL., 39. Anais ..., Salvador, SBG - Núcleo BAISE, vol. 3: 197-200.

READ, P. G. 1991. Gemmology. Butterworth Heinemann, Oxford, 358p.

REEVES, R. G. 1966. Geology and mineral resources of the Monlevade and Rio Piracicaba quadrangles, Minas Gerais, Brazil. U. S. Geol. Surv. Prof. Pap., 341-E, 58p, Washington.

RETTINGER, R. 1997. Thermometamorphic characterization of the transition zone between the Archean São Francisco Craton and the Proterozoic mobile belt, Minas Gerais, Brazil. Tese de Doutorado, Faculdade de Matemática e Ciências Naturais - Universidade de Potsdam. 158p. (Inédito).

RETTINGER, R.; SCHORSCHER, H. $\quad$ D.; OBERHÄNSLI, R. 1996. Geothermobarometric correlation of geothermobarometers and petrogenetic modelling in NE-Quadrilátero Ferrífero, Minas Gerais, Brazil. Zbl. Geol. Paläont. Teil I, 1994(7/8):613-625.

RIBBE, P. H. 1983. Aluminium-silicon order in feldspars: domain textures and diffraction patterns. In: RIBBE, P. H. (ed.), Feldspar Mineralogy. Reviews in Mineralogy, 2:21-55.

ROEDDER, E. 1984. Fluid Inclusions. Reviews in Mineralogy, v.12, 644p.

ROEDDER, E.; INGRAM, B.; HALL, W. R. 1963. Studies of fluid inclusions III: Extraction and quantitative analyses of inclusions in the miligram range. Econ. Geol. 58:353-374.

SANFORD, R. F. 1982. Growth of ultramafic reaction zones in greenschist to amphibolite facies metamorphism. Amer. Journ. Sci, 282:543-616. 
SCHORSCHER, H. D. 1976. Polimetamorfismo do Pré-Cambriano na região de Itabira, Minas Gerais, Brasil. In: CONGR. BRAS. GEOL., 29. Ouro Preto, 1976, Boletim dos Trabalhos, p.194-195.

SCHORSCHER, H. D. 1979. Evolução geotectônica e petrogenética do embasamento arqueano do Quadrilátero Ferrífero. An. Acad. bras. Ciênc., 51(4):767-768.

SCHORSCHER, H. D. 1988. NE Qadrilátero Ferrifero and adjacent areas. In: INT. CONFERENCE: GEOCHEMICAL EVOLUTION OF THE CONTINENTAL CRUST. Poços de Caldas, 1988, Guidebook, 96p.

SCHORSCHER, H. D. 1992. Arcabouço petrográfico e evolução crustal de terrenos precambrianos do sudeste de Minas Gerais: Quadrilátero Ferrífero, Espinhaço Meridional e domínios granito-gnáissicos adjacentes. Tese para concurso de Livre-Docência, IG-USP, 274p., 2 vol. (Inédito).

SCHWARZ, D. 1987. Esmeraldas: Inclusões em Gemas. Ouro Preto, Imprensa Universitária/UFOP, 439p.

SEYBERT, H. 1824. Analyses of the Chrysoberyls from Haddam and Brazil. Amer. Journ. Sci., Series 1, 8(1):105-112.

SHANNON, R. D.; PREWITT, C. T. 1969. Effective ionic radii in oxides and fluorides. Acta Cryst., B25:925-946.

SHEPHERD, T. J.; RANKIN, A. H.; ALDERTON, D. H. M. 1985. A Practical Guide to Fluid Inclusion Studies. Blackie.

SIMPSON, C. 1985. Deformation of granitic rocks across the brittle-ductile transition. J. Struct. Geol., 7(5):503-511. 
SINKANKAS, J. 1981. Emerald and other beryls. Pennsylvania, Chilton Book Co. $665 p$.

SOMAN, K.; DRUZHININ, A. V. 1987. Petrology and geochemistry of chrysoberyl pegmatites of south Kerala, India. Neues Jahrbuch Miner. Abh., 157(2):167183.

SOMAN, K.; NAIR, G. K. 1985. Genesis of chrysoberyl in the pegmatites of southern Kerala, India. Mineral. Mag., 49:733-738.

SOUZA, J. L. 1988. Mineralogia e geologia da esmeralda da jazida de Itabira, Minas Gerais. Dissertação de Mestrado, IG-USP, 192p. (Inédito).

SOUZA, J. L.; MENDES, J. C.; BELLO, R. M. S.; SVISERO, D. P.; VALARELLI, J. V. 1992. Petrographic and microthermometrical studies of emeralds in the Garimpo of Capoeirana, Nova Era, Minas Gerais State, Brazil. Mineralium Deposita, 27(2):161-168.

STOCKTON, C. M.; KANE, R. E. 1988. The distinction of natural from synthetic alexandrite by infrared spectroscopy. Gems \& Gemology, 24(1):44-46.

STRECKEISEN, A. 1976. To each plutonic rock its proper name. Earth Sci. Rev., 12(1):1-33.

SUNAGAWA, I. 1982. Gem materials, natural and artificial. Current Topics in Materials Science, 10:353-497.

TEIXEIRA, W.; DOSSIN, I. A.; DOSSIN, T. M.; SALVADOR, E. D.; SIGA Jr., O.; SATO, K. 1990. Interpretação do contexto geotectônico do embasamento da borda leste do Sistema Espinhaço, região de Guanhães e Gouveia - MG, com base numa integração do seu conjunto geocronológico U/Pb, Rb/Sr e KJAr. In: CONGR. BRAS. GEOL., 36, Natal, 1990. Anais ... Natal, SBG, 6:2711-2722. 
TEIXEIRA, W.; CARNEIRO, M. A.; NOCE, C. M.; MACHADO, N.; SATO, K.; TAYLOR, P. N. 1996. $\mathrm{Pb}, \mathrm{Sr}$ and $\mathrm{Nd}$ isotope constraints on the Archaean evolution of gneissic-granitoid complexes in the southern São Francisco Craton, Brazil. Precambrian Res., 78:151-164.

TRÖGGER, W. E. 1979. Optical determination of rock forming minerals.Part I: Determinative tables. Stutgart, E. Schweizerbartsche Verlagsbuchhandlung. $188 \mathrm{p}$.

TULLIS, J. 1983. Deformation of feldspars. In: RIBBE, P. H. (ed.), Feldspar Mineralogy. Reviews in Mineralogy, 2:297-323.

VIEIRA, V. S. 1985. Projeto Mapas Metalogenéticos e de Previsão de Recursos Minerais. Folha Guanhães - Texto e Mapas. DNPM/CPRM, 26p.

VITYK, M. O.; BODNAR, R. J. 1995. Textural evolution of synthetic fluid inclusions in quartz during reequilibration, with applications to tectonic reconstruction. Contrib. Mineral. Petrol., 121:309-323.

VITYK, M. O.; BODNAR, R. J. 1998. Statistical microthermometry of synthetic fluid inclusions in quartz during decompression reequilibration. Contrib. Mineral. Petrol., 132:149-162.

VOLL, G. 1976. Recrystallization of quartz, biotite, and feldspars from Erstfeld to the Leventina Nappe, Swiss Alps, and its geological significance. Schweiz. Miner. Petrog. Mitt., 56:641-647.

VOLLBRECHT, A.; SIEGESMUND, S.; FLAIG, C. 1997. High-temperature deformation of a granitoid from the Zone of Erbendorf-Vohenstrauss (ZEV). Geol. Rundsch., 86, Suppl:S141-S154.

WEBSTER, R.; ANDERSON, B. W. 1983. Gems: their sources, descriptions and identification. $4^{\text {th }}$ ed. London, Butterworths. 1006p. 
WHITE, W. B.; ROY, R.; CRICHTON, J. M. 1967. The "alexandrite effect": an optical study. Amer. Mineral., 52:867-871.

WUENSCH, B. J.; HÖRMANN, P. K. 1969. Beryllium. In: WEDEPOHL, K. H. (ed.): Handbook of Geochemistry, Vol.II/1. Berlin, Springer-Verlag, c.4.

ZABOLOTNAYA, N. P. 1977. Deposits of Beryllium. In: SMIRNOV, V. I. (ed.). Ore Deposits of the USSR. Vol. 3. Pitman Publishing. p.320-371. 